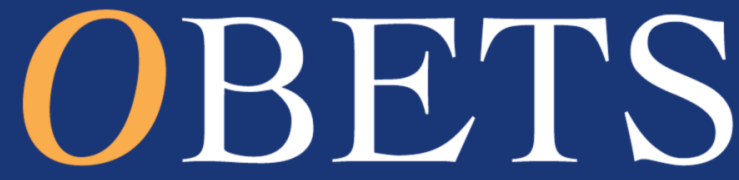

Revista de

Ciencias Sociales

vol. $13 \cdot n^{\circ} 2$

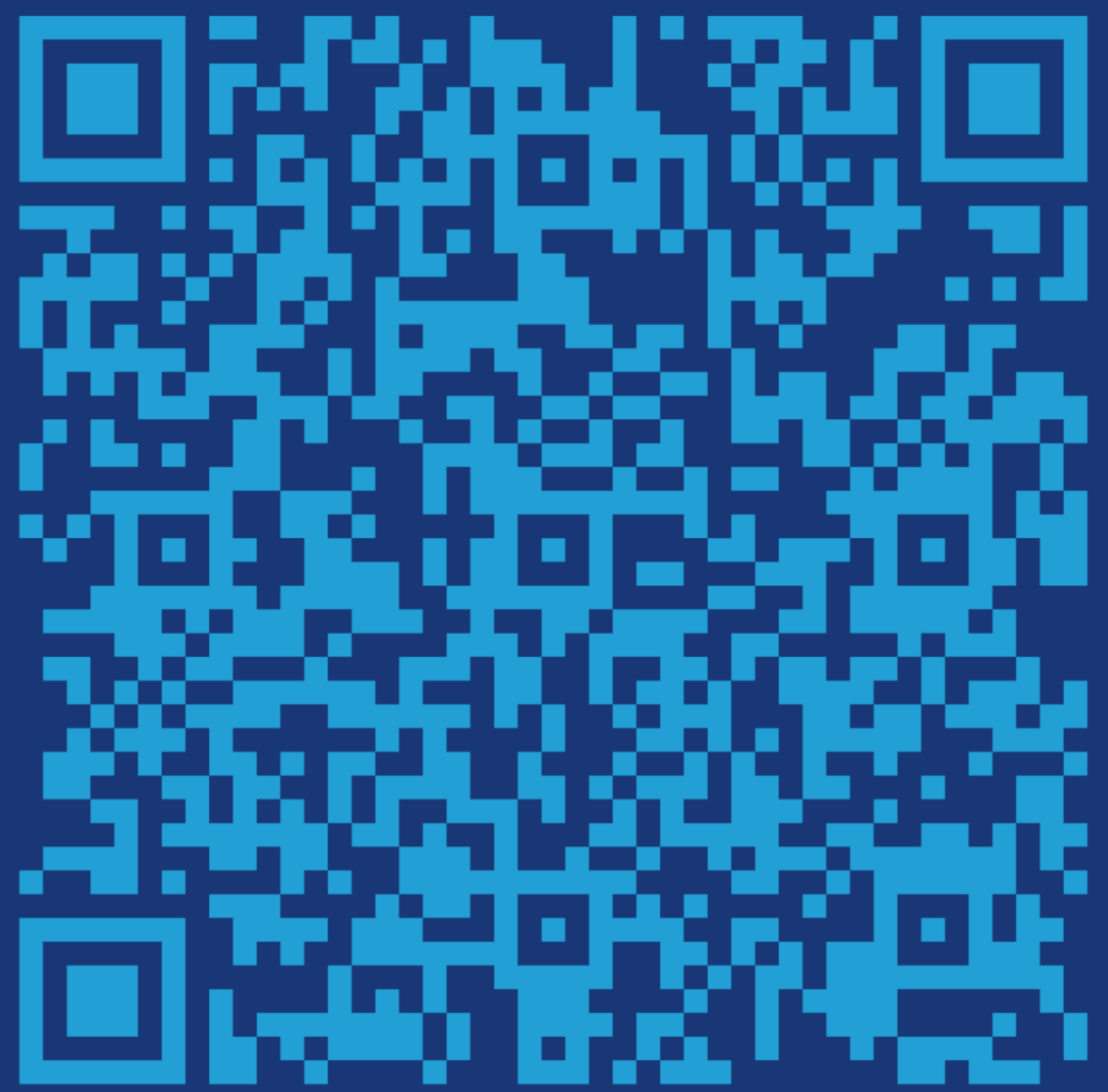

Julio-diciembre 2018

Instituto Interuniversitario de Desarrollo Social y Paz Universidad de Alicante

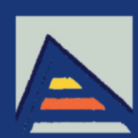

Universitat d'Alacant Universidad de Alicante 

OBETS

Revista de Ciencias Sociales 



\section{OBETS}

REVISTA DE CIENCIAS SOCIALES

PUBLICACIONES DE LA UNIVERSIDAD DE ALICANTE 
El presente número de la revista ha obtenido una ayuda del Vicerrectorado de Investigación, Desarrollo e Innovación de la Universidad de Alicante

Publicaciones de la Universidad de Alicante

Campus de San Vicente s/n

03690 San Vicente del Raspeig

Publicaciones@ua.es

http://publicaciones.ua.es

Teléfono: 965903480

Fax: 965909445

(C) de la presente edición: los autores

OBETS. Revista de Ciencias Sociales.

Editada por IUDESP.

Instituto Interuniversitario de Desarrollo Social y Paz.

Universidad de Alicante.

Periodicidad: Semestral

http://revistaobets.ua.es

Email: revistaobets@ua.es

e-ISSN: 1989-1385

Depósito legal: A-885-2008

DOI: 10.14198/OBETS

Diseño de portada: candela ink. / O. Santacreu

Composición: Patricia Barbero

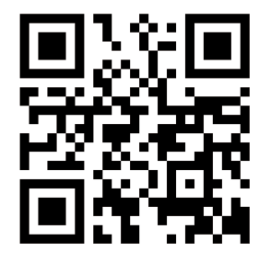

Los contenidos están bajo una licencia Creative Commons Reconocimiento 4.0 España.

Los contenidos pueden copiarse, distribuirse o comunicarse públicamente, bajo las siguientes condiciones generales: Reconocimiento. Debe reconocerse los créditos de la obra de la manera especificada por el autor o el licenciador (pero no de una manera que sugiera que tiene su apoyo o apoyan el uso que hace de su obra). Los términos de la licencia disponibles on-line en: http://creativecommons.org 
OBETS, Revista de Ciencias Sociales es una revista de investigación de periodicidad semestral editada por el Observatorio Europeo de Tendencias Sociales (OBETS), grupo de investigación integrado en la sede de la Universidad de Alicante (España) del Instituto Interuniversitario de Desarrollo Social y Paz (IUDESP). Dirigida a profesionales, investigadores/as, estudiantes, profesorado y público general interesado en la investigación académica en el campo de las Ciencias Sociales, comenzó a editarse en 2008.

La revista tiene como objetivo la difusión de estudios de naturaleza académica que contribuyan al mejor conocimiento de la sociedad contemporánea. En este sentido está abierta a la publicación de resultados de investigación empírica, metodológica o teórica de ámbito nacional e internacional. La revista abarca un amplio abanico de temas inscritos en el ámbito de la Sociología y Ciencias Sociales, como estudios de opinión pública, metodología, demografía, estructura y cambio social, ciencia política, teoría sociológica, antropología o psicología social. Los trabajos se publican en español, inglés, italiano, portugués o valenciano/catalán.

La revista está integrada en RUA, Repositorio Institucional de la Universidad de Alicante y cumple con el estándar de metadatos Dublin Core (http://www.dublincore.org) y con el protocolo OAI-PMH (Open Archives Initiative-Protocol for Metadata Harvesting: http://www.openarchives.org) para la transmisión de contenidos en Internet. Cuenta también con el DOI 10.14198/OBETS. A través de su página web y del RUA la revista ofrece opciones de acceso a contenido por títulos, autores, palabras claves o fecha.

A fin de alcanzar el mayor nivel de calidad posible en los trabajos publicados, todos los artículos se someten al arbitraje por pares académicos, considerando tanto la novedad de los resultados como el rigor metodológico en los diseños de investigación y análisis. El equipo editorial de OBETS. Revista de Ciencias Sociales no se hace responsable, en ningún caso, de la credibilidad y autenticidad de los trabajos. Del mismo modo, las opiniones y hechos expresados en cada artículo son de exclusiva responsabilidad de sus autores/as y OBETS. Revista de Ciencias Sociales no se identifica necesariamente con ellos. 
BASES DE DATOS

\begin{tabular}{|c|c|}
\hline & $\begin{array}{l}\text { ESCI (Emerging Sources Citation Index) - Producto de la } \\
\text { Web of Science (WoS) editada por Thomson Reuters }\end{array}$ \\
\hline & $\begin{array}{l}\text { SCOPUS - Base de datos bibliográfica de resúmenes y citas } \\
\text { de artículos de revistas científicas editada por Elsevier }\end{array}$ \\
\hline & DOAJ - Directory of Open Access Journals \\
\hline D & $\begin{array}{l}\text { DICE - Base de datos para la difusión y calidad editorial de } \\
\text { las revistas españolas de humanidades y ciencias sociales y } \\
\text { jurídicas }\end{array}$ \\
\hline & $\begin{array}{l}\text { ÍnDICEs-CSIC - Recurso bibliográfico multidisciplinar que } \\
\text { recopila y difunde principalmente artículos de investigación } \\
\text { publicados en revistas científicas españolas }\end{array}$ \\
\hline ULRIC & $\begin{array}{l}\text { ULRICH'S - Base de datos de publicaciones periódicas } \\
\text { internacionales }\end{array}$ \\
\hline & $\begin{array}{l}\text { Google Scholar - Buscador de google especializado en } \\
\text { documentos académicos con recuento de citas }\end{array}$ \\
\hline
\end{tabular}




\section{SISTEMAS DE EVALUACIÓN}

\begin{tabular}{|c|c|}
\hline & $\begin{array}{l}\text { SJR - Consiste en una medición de la influencia científica de } \\
\text { revistas académicas que tiene en cuenta tanto el número de } \\
\text { citas recibidas por una revista como la relevancia o el } \\
\text { prestigio de la revista de la que proceden dichas citas }\end{array}$ \\
\hline & $\begin{array}{l}\text { RESH - Sistema de valoración integrada de revistas españolas } \\
\text { de Humanidades y Ciencias Sociales }\end{array}$ \\
\hline$E$ & CIRC - Clasificación Integrada de Revistas Científicas \\
\hline & MIAR - Matriz de información para la evaluación de revistas \\
\hline & $\begin{array}{l}\text { ANVUR - Agenzia per la valutazione del sistema } \\
\text { Universitario e della ricerca (Italia). Revista evaluada } \\
\text { favorablemente como Revista Clase A (área 14) }\end{array}$ \\
\hline & $\begin{array}{l}\text { Latindex (Catálogo) - Sistema regional de información en } \\
\text { línea para revistas científicas de América Latina, el Caribe, } \\
\text { España y Portugal. Incluye únicamente las revistas (impre- } \\
\text { sas o electrónicas) que cumplen los criterios de calidad edi- } \\
\text { torial diseñados por Latindex }\end{array}$ \\
\hline MEO & $\begin{array}{l}\text { SHERPA/RoMEO - Políticas de copyright de las editoriales } \\
\text { y autoarchivo. Universidad de Nottingham. }\end{array}$ \\
\hline ब్రా DULCINEA & $\begin{array}{l}\text { Dulcinea - Proyecto coordinado por el Ministerio de } \\
\text { Educación y Ciencia para identificar y analizar las políticas } \\
\text { editoriales de las revistas científicas españolas }\end{array}$ \\
\hline
\end{tabular}

\section{PORTALES DE DIFUSIÓN}

\begin{tabular}{|l|l|}
\hline REDIB & $\begin{array}{l}\text { REDIB - Red Iberoamericana de Innovación y Conocimiento } \\
\text { Científico }\end{array}$ \\
\hline O Dialnet & $\begin{array}{l}\text { Dialnet - Portal de difusión de la producción científica } \\
\text { iberoamericana impulsado por la Universidad de La Rioja }\end{array}$ \\
\hline
\end{tabular}





\section{EQUIPO EDITORIAL}

\section{Consejo de redacción}

Dirección:

Oscar Antonio Santacreu Fernández - IUDESP. Universidad de Alicante, España

Secretaría:

Francisco José Francés García - Departamento Sociología II. Universidad de Alicante, España

Liberto Carratalá Puertas. Departamento Sociología I. Universidad de Alicante, España

Vocales:

- Mercedes Alcañiz Moscardó - Universitat Jaume I de Castellón, España

- Cristino Barroso - Universidad de La Laguna, España

- Mario Alejandro Guillén García - Programa Interdisciplinario de Población y

Desarrollo Local Sustentable (PYDLOS), Universidad de Cuenca, Ecuador

- Nina Rother - BAMF. Alemania

- Natalia Ix-Chel Vázquez González - Facultad de Ciencias Políticas y

Administración Pública. Universidad Autónoma del Estado de México, México

\section{Comité científico}

- Alberto Acosta Espinosa - Facultad Latinoamericana de Ciencias Sociales (FLACSO), Ecuador

- Antonio Alaminos Chica - IUDESP. Universidad de Alicante, España

- José Beltrán Llavador - Dpto. Sociología y Antropología Social, Universidad de Valencia, España

- Gianfranco Bettin - Università degli Studi di Firenze, Italia

- José Manuel Canales Aliende - Dpto. de Estudios Jurídicos del Estado, Universidad de Alicante, España

- Vidal Díaz de Rada - Universidad Pública de Navarra, España

- Guillermina Díaz Pérez - Universidad Autónoma del Estado de México

- Mariano Fernández Enguita - Universidad Complutense de Madrid, España

- Margarita Latiesa Rodríguez - Universidad de Granada, España

- María Asunción Martínez Román - Dpto. Trabajo Social y Servicios Sociales.

Universidad de Alicante, España

- Beatriz Padilla - Instituto Universitário de Lisboa (ISCTE-IUL), Lisboa, Portugal

- Andrea Pirni - University of Genova, Italia

- Ettore Recchi - Università degli Studi 'G. d'Annunzio' Chieti e Pescara, Italia

- M'hammed Sabour - University of Eastern Finland, Finlandia

- Pedro Sánchez Vera - Universidad de Murcia, España

- Sylvie Strudel - Université Panthéon-Assas, Paris, Francia

- José María Tortosa Blasco - IUDESP. Universidad de Alicante, España

- Anna Triandafyllidou - European University Institute, Florencia, Italia; ELIAMEP,

Atenas, Grecia 


\section{ESTADÍSTICAS 2018}

Durante el año 2017 se recibió una gran cantidad de artículos (100) de los que se llegaron a evaluar el $74 \%$. Ello tuvo como efecto que el consejo de redacción de la revista tomara la decisión de cerrar temporalmente la recepción de artículos en 2018. Ambas circunstancias afectan a las estadísticas del año 2018.

Así, sin contar los artículos pendientes del período anterior, la revista ha recibido en 2018 un total de 38 artículos. Durante el mismo año se ha concluido la evaluación externa (revisión por pares de forma anónima) de 28 artículos (74\%), quedando 10 artículos (26\%) en proceso de evaluación.

De los 28 artículos evaluados, 7 han sido aceptados (25\%), de los cuales 4 (57\%) fueron remitidos a sus autores/as a fin de incorporar las modificaciones propuestas por las evaluaciones. Cada artículo ha sido revisado por una mediana de 2 revisores/as. Cada revisor/a ha evaluado una mediana de 1 trabajo.

En los números publicados en 2018 (incluyendo el presente número) el tiempo medio de espera de los artículos aceptados, desde su recepción hasta su aceptación definitiva, ha sido de 230 días (mediana 237), y el tiempo medio entre aceptación y publicación ha sido de 103,7 días (mediana 101).

Tabla 1. Resumen estadísticas 2018

\begin{tabular}{l|c|c}
\hline \multirow{2}{*}{ Artículos } & \multicolumn{2}{|c}{ Artículos originales } \\
\cline { 2 - 3 } Recibidos & Número & Porcentaje \\
\cline { 2 - 3 } & 38 & \\
\hline Pendientes & 10 & $26,3 \%$ \\
\hline Evaluados, de los cuales: & 28 & $73,7 \%$ \\
\hline - Rechazados & 21 & $75 \%$ \\
\hline - Aceptados, de los cuales & 7 & $25 \%$ \\
\hline -- Aceptados con modificaciones & 4 & $57 \%$ \\
\hline
\end{tabular}

Tabla 2. Tiempos del proceso editorial

\begin{tabular}{l|c}
\hline Tiempos entre & Artículos originales \\
\hline & 2018 . Días \\
M/₫DS/Me \\
\hline Recepción/aceptación & $230 / 113,6 / 237$ \\
\hline Aceptación/publicación & $103,7 / 55,57 / 101$ \\
\hline
\end{tabular}

Nota: M/₫DS/Me = Media/Desviación Estándar/Mediana 


\section{INDICE}

ARTÍ́CUlOS .................................... 465

Antonio Alaminos, Clemente Penalva, Luca Raffini, Óscar Santacreu

Cognitive mobilisation and the dynamics of political participation among EU movers ........................... 467

La movilización cognitiva y la dinámica de la participación política entre los migrantes intraeuropeos

María Espada, María Martín, Víctor Jiménez, David Moscoso, Emilio Jiménez-Beatty

Leisure sports habits in spanish adults: gender and social differences .................................. 495

Hábitos deportivos de ocio en adultos españoles: género y

diferencias sociales

\section{Lucía García-Carretero, Javier Díaz-Noci}

From social movements to political parties. Barcelona en Comu's electoral message, uses and limitations on Twitter during 2015 city council election

De movimientos sociales a partidos políticos. Mensaje electoral, usos y limitaciones de Twitter por parte de Barcelona en Comú en las elecciones municipales de 2015

Izarne Lizaso Elgarresta, Inmaculada Sánchez-Queija, Águeda Parra Jiménez, Enrique Arranz Freijo La participación social online y offline de estudiantes universitarios españoles ......................... 547 Online and offline social participation of Spanish graduate students 
José Ocón-Domingo, Clemente Rodríguez-Sabiote, Daniel Álvarez-Ferrándiz

Perfiles de opinión de los estudiantes universitarios acerca de la homoparentalidad en el contexto actual de metamorfosis familiar 569 Opinion profiles of the university students about homoparenthood in the familiar metamorphosis current context

Irene Pazos-Carro, Ana-Isabel Souto-Gómez, Miguel-Ángel Talavera-Valverde

Análisis de desempeño ocupacional de las personas en situación de desalojo en la ciudad de A Coruña (Galicia-España) 593 Analys of the occupational performance of people in situations of eviction in the city of A Coruña (Galicia. Spain)

\section{Rocío Pérez Gañan}

Entre "Cáritas" y "trabajar demasiado": etnia, género y religión en la experiencia migratoria de pueblos originarios ecuatorianos en España

Between "Cáritas" and "working too much": Ethnicity and religiosity in the migration experiences in southern Ecuador and central-eastern Spain

Juan A. Rodríguez del Pino, Teresa Samper Mas, Susana Marin Traura, Enric Sigalat Signes, Ana Elisa Moreno Ruíz Hombres cuidadores informales en la ciudad de Valencia. Una experiencia de reciprocidad . . . . . . . . . . . . . . . . . 645 Informal male caregivers in the city of Valencia. An experience of reciprocity

NORMAS EDITORIALES E INSTRUCCIONES PARA COLABORACIONES 671

\section{EDITORIAL STANDARDS AND INSTRUCTIONS FOR}


ARTículos ARTICLES 



\title{
COGNITIVE MOBILISATION AND THE DYNAMICS OF POLITICAL PARTICIPATION AMONG EU MOVERS ${ }^{1}$ \\ LA MOVILIZACIÓN COGNITIVA Y LA DINÁMICA DE LA PARTICIPACIÓN POLÍTICA ENTRE LOS MIGRANTES INTRAEUROPEOS
}

\author{
Antonio Alaminos \\ Universidad de Alicante, España \\ alaminos@ua.es \\ Clemente Penalva \\ Universidad de Alicante, España \\ clemente.penalva@ua.es \\ Luca Raffini \\ Università di Genova, Italia \\ lucaraffini@gmail.com \\ Óscar Santacreu \\ Universidad de Alicante, España \\ oscar.santacreu@ua.es
}

Cómo citar / citation

Alaminos, A. Penalva, C., Raffini, L. y Santacreu, Ó. (2018) "Cognitive mobilisation and the dynamics of political participation among EU movers". OBETS. Revista de Ciencias Sociales, 13(2): 467-494. doi: 10.14198/OBETS2018.13.2.01

${ }^{1}$ This research has been funded by the project MOVEACT - "All Citizens Now": IntraEU Mobility and Political Participation of English, Germans, Poles and Romanians in Western and Southern European Cities (MOVEACT), a project funded by European Commission, Directorate-general of Justice, Freedom and Security. 


\begin{abstract}
Non-conventional participation has dramatically spread because of cultural and social change, favouring a deinstitutionalisation of politics. To verify if there is a link between this spread of non-conventional participation and the mobility of Europeans living in other European countries, we have explored the data gathered by the MOVEACT European project, including data on the political behaviour of "old Europeans" (British and Germans), and "new" Europeans" (Poles and Romanians), resident in Greece, France, Italy and Spain. Our analysis has confirmed that a plurality of variables affect the relation between movers and non-conventional participation. There are three relevant dimensions to explain the unconventional political participation of EU movers: social integration, situational context and individual characteristics. On the other hand, the key aspect to understand the non-conventional participation of EU movers is the degree of Cognitive Political Mobilisation, together with other factors such as membership of associations, family socialisation, expectations of living in the country of residence in the future or the political culture in the country of origin.
\end{abstract}

Keywords; Mobility; Participation; European Citizenship; Cognitive Mobilisation; Political Socialisation

\title{
Resumen
}

La participación política no convencional se ha extendido intensamente debido al cambio cultural y social, favoreciendo el proceso de desinstitucionalización de la política. Para comprobar si existe un vínculo entre esta difusión de la participación no convencional y la movilidad de los europeos que viven en otros países europeos, hemos explorado los datos recopilados por el proyecto europeo MOVEACT, incluyendo los datos sobre el comportamiento político de los "viejos europeos" (Británicos y alemanes), y de los "nuevos europeos" (polacos y rumanos), todos ellos residentes en Grecia, Francia, Italia y España. Nuestro análisis ha confirmado que hay una pluralidad de variables que intervienen en la relación entre las personas que experimentan esta movilidad internacional europea ("EU movers") y la participación política no convencional. Existen tres dimensiones relevantes para explicar la participación política no convencional en esta movilidad interna europea: integración social, contexto situacional y características individuales. Por otro lado, se observa que el aspecto clave para entender la participación no convencional de estos "UE movers" es el grado de movilización política cognitiva. Junto a ésta aparecen otros factores como son la pertenencia a asociaciones, la socialización familiar, las expectativas de vivir en el país de residencia en el futuro o la cultura política en el país de origen.

Palabras clave; Movilidad; participación; Ciudadanía Europea; Movilización Cognitiva, Socialización Política 


\section{INTRODUCTION}

\subsection{The shift from conventional participation to non-conventional participation in advanced societies}

Current democracies are characterised by internal and external challenges, regarding both the scale and the quality of democratic processes. The shift of power from States to international government organisations challenges the territorial understanding of popular sovereignty. In the context of globalisation, States are neither the only, nor the main loci of political processes, as decisions are more and more taken in supranational organisations and networks, comprising a multilevel governance system. The shift of power and the development of new paths and styles of policymaking are reflected in a deep transformation of the meaning and practices of citizenship. Democracy is subject to risks and challenges -affecting the national liberal-representative modelsand new opportunities are rising from the making of postnational policies. This is especially the case in the European Union, where, as a result, political and civic participation are more and more loosening their national ties, reallocating in transnational networks, linking local and global dimensions. Advanced democracies have been labelled by Colin Crouch as "post-democracies" (Crouch, 2004), where citizens feel "a certain estrangement of the members of the polity from both its core political institutions and, more generally, from politics" (Torcal and Montero, 2006: 49).

According to Pharr and Putnam (2000), in "disaffected democracies", interest in politics and participation, in every form, are declining, influencing both institutional participation and civic engagement as social capital is deteriorating. According to an alternative point of view, citizens' distrust is not, per se, conducive to political alienation and to antidemocratic attitudes. On the contrary, it can promote the search for new forms of political commitment and a democratic experimentalism, especially regarding the collective practices of young people (Francés 2008; Raffini 2008). Thus, the crisis of conventional participation (Milbrath et al., 1977) is partially counterbalanced by the spread of non-conventional forms of participation (Barnes and Kaase, 1979).

Demonstrating, signing petitions, practising political consumerism, engaging in single-issue movements and in informal networks, in spontaneous rallies and in protest events, are becoming ordinary forms of action. Also, civic engagement in associations and neighbours' organisations, even if not directly politically oriented, are relevant as instruments of social participation.

New forms of cosmopolitan-oriented forms of solidarity are rising and experiments in new practices of democratic participation -beyond national borders- have been conducted. 
Collective action and civic engagement can be integrated in a wider notion of political and social involvement, if we define participation as "the various ways in which individuals take part in the management of the collective affairs of a given political community" (Martiniello, 2006: 84), in a direct or indirect way, instrumentally and expressively (Klandermans, 1997). Furthermore, political and social participation, especially in the realm of non-conventional politics, can be locally, nationally or globally oriented and committed to link these different levels, promoting social and political networking.

These changes in political values and behaviours have been analysed in the context of wider trends of social change. Economic growth and greater levels of education favour the development of sceptical views toward hierarchies and bureaucratic structures and the spread of a more critical stance toward institutions. Indeed, the level of education has a significant effect on participation, both directly and indirectly (Santacreu, 2008). Cultural and cognitive skills are strongly correlated with value change and shape the ability to explore new political and social practices beyond borders. Cultural and cognitive resources explain not merely the degree of commitment, but also the type of involvement, and high-skilled individuals are leading actors in the reinvention of politics. A key concept in explaining the change in political orientations is cognitive mobilisation, describing an individual relation with society and politics by educated and skilled citizens, who do not need to be within the framework of political organisations as parties in order to be politically committed. As Russel Dalton states, in advanced societies (political) cognitive mobilisation is more and more substituting party mobilisation, allowing for an individualised and disintermediated relationship with politics. With the concept of cognitive mobilisation Dalton (1984) and Inglehart (1990) describe sophisticated, apartisan citizens whose cognitive and cultural skills provide them with resources to deal with political information and manage the complexities of politics without reliance on affective, habitual party cues. Cognitive mobilisation is strictly related to a general trend of change in individuals' values and attitudes in latemodern society, concerning also belonging and identities. Cognitively mobilised individuals tend to be more globally oriented and less linked to national identification. As a consequence, they are also carriers of a de-nationalised framing of politics and more inclined to develop social and political transnationalism (Duchesne, 2008). From a recent analysis we know that higher-class citizens are objectively and subjectively more Europeanised. They experience mobility, both virtual and physical, more than middle- and lower-class people, they express more interest in European matters and they feel themselves more Europeans than their fellow citizens (Baglioni and Recchi 2013). As intra-European mobi- 
lity and Europeanisation are proved to be positively associated with having high social, economic and cultural resources, and the latter are also positively correlated with the experimentation of new kinds of social and political involvement, we expect European movers -i.e., EU citizens who have moved to live in a member state other than their own- to be particularly active in non-conventional politics. They represent a strategic component of the EU citizenry, as they live an experience of transnationality in their daily life (Glick Schiller et al., 1992). They could play a leading role in triggering the process of "horizontal Europeanisation" (Mau, 2010) and, as "pioneers of European integration" (Recchi and Favell, 2013), they are also potentially leading actors in the experimentation with novel forms of political involvement.

\subsection{European integration and the reinvention of politics}

Globalisation and Europeanisation deeply change political behaviours and repertoires of participation. European citizens participate in an unprecedented political, social and cultural experiment. Innovative forms of social and political involvement stem not only from the redefinition of the citizenship status, but are the result of social practices, such as intra-European mobility. Global society has been defined as the "age of migration" (Castles and Miller, 2009). Spatial mobility contributes to the redefinition of a social experience beyond borders, and, along with information and mobility of goods, to the creation of a network society (Castells, 1996), where fluxes overcome geographical, economic, cultural and political borders. Indeed, the political activism of nonnationals is in a broad framework of analysis inherent to social change. Migration and mobility challenge the national understanding of society, demanding for the overcoming of the notion of "national container of society" (Beck, 1992), also in terms of political organisation.

The EU is a privileged institutional framework for political transnationalisation: European citizens have the right to vote at European elections and to choose their representatives in the European Parliament. They also have the right to freely circulate and to settle in other European countries and the right to vote from the country of residence at European and local elections. As a result, citizenship loses its national framing and is redefined at three levels: the European level, the national level, and the local residence level.

Voting is not the only instrument that EU citizens have to express their views at local, national and European level. Many experts stress the role of transnational movement networks and NGOs in the promotion of bottom-up mobilisation on European issues. The "Europeanisation from below", can contribute to the formation of a European public sphere (della Porta and Caiani, 
2010) and a European demos, socially and politically committed to the construction of European society, not only as passive subjects, but as leading actors. These theories turned out to be optimistic, as empirical studies converge in stating that a truly European public sphere does not yet exist (De Vreese, 2007) and the population of transnational activists still represents a small segment of the European population, in a context still characterised by disinterest and low commitment. They nevertheless identify actual dynamics of change, the analysis of which can encourage thinking on the possible path of self-constitution of European democratic policies (Trenz and Eder, 2009). The analysis of the change in political protest, mobilisation and transnational campaigns suggests that non-conventional participation actors have been able to modify their repertoires and scale of action, more than traditional political organisation (i.e. parties). Non-conventional participation is nowadays a consolidated instrument used by European citizens to express their voice, to generate solidarity and build common frameworks with their fellow European citizens and to influence policymaking, when institutional channels are deemed to be restricted or not fully accountable to people.

To sum up, non-conventional participation has dramatically spread as a consequence of cultural and social change, favouring a deinstitutionalisation of politics, but the shift of power toward supranational institutions exacerbates this trend of change, as non-conventional participation in fluid and loose transnational networks is revealed to be more equipped than conventional participation actors in dealing with the rescaling of politics. In this sense the EU can be looked upon as a laboratory of the reinvention of politics, where institutional change exacerbates the pre-existing trend of change in political participation and gives prominence to the role of transnational movements and informal networks, committed to a bottom-up democratisation of European society. The non-conventional participation experienced within movements is characterised, in se, as participation beyond borders, as it horizontally links people and groups from different places, and is accordingly favoured by the spread of ICTs.

Some features of non-conventional political participation are noteworthy, as they explain why this type of involvement fits well also with the experience of both virtual and geographical mobility. First, we must highlight the discontinuous nature of unconventional participation. Faced with the relative continuity of conventional participation, which is marked by election dates that imply a specific time schedule, unconventional participation can be characterised by discontinuity in the sense that all the actions (signing a petition or a letter to a politician, participating in a protest or a boycott, going on strike or 
occupying a public place) are usually carried out in certain moments in which it is considered appropriate to make some sort of political statement. Second, their collective character must be considered. In contrast to the individual exercise of voting (even secret voting), the public side of collective action is intertwined with group-like interfaces such as organisations. Belonging to an organisation (with varying degrees of involvement and identification) increases the likelihood of participating in political action, because there is more information not only about the calls for mobilisation but also, and this is very important in the places of residence of migrants, about the social and political context and the issues/actions to be challenged. In addition, the organisation allows participants to apply the principle of individual interest (issues that directly affect the individual) and mutual support (matters that do not directly affect the individual but others with whom he/she sympathises). All these features fit with the movers' condition: non-conventional participation is more accessible, as it is less dependent on national framings, allows for a participative continuity and it is also able to match the needs and demands of mobile people.

These conditions foster the political participation of movers: the opportunity (particular threats to their rights as citizens, for example) and membership of an organisation (which provides information and establishes collective action). Organisations that are relevant in this sense are civic associations (very heterogeneous in terms of purpose and structure), because they combine integration (social networks, roots) with opportunity.

\subsection{Mobility, participation and collective action}

In traditional research on migration and political participation there is little room for an individual path of integration and much attention has been paid to the role of collective actors and networks. Furthermore, the concept of social capital has been usually treated as a group-level variable, depending on the characteristics of ethnic networks (cfr. Morales and Giugni 2011). To understand the repertoire of civic engagement and non-conventional participation of European citizens the ethnic social capital approach may be inadequate, or at least needs to be integrated and revised, as European movers experience mobility as fully-fledged citizens, and their legal and subjective status are meant to push toward more individualised forms of integration and political mobilisation.

Putnam's theory of social capital and empirical research on migration rooted in this theory are still premised on an implicit "national methodolo- 
gism", and they are not fully able to grasp the post-national views, lifeworlds or experiences of citizens such as EU movers. In this sense, theories of transnationalisation seem to fit better, describing citizens who redefine their social relations, and consequently, their political and social paths of mobilisation, beyond geographical and political borders, not just reproducing their collective identity in the country of residence, but remoulding it in a cosmopolitan way, as they are inserted in multiple social networks.

Given their objective and subjective condition, EU movers are potentially leading actors in the reinvention of politics, as transnationalisation is strongly linked to the spread of new types of social and political commitment. Yet, the experimentation of new participatory practices, inside and outside the political system, is not an automatic result of mobility, but depends on the combination of individual characteristics and attitudes and structural macro variables. Besides, micro and macro variables do not act independently, as citizens coming from different countries of origin also have different social profiles.

The population of mobile Europeans is highly heterogeneous, in terms of individual characteristics and trajectories of mobility. Behind the formal equality provided by EU citizenship we find quite diverse types of mobility from economic to lifestyle to romance-driven migration. A multivariate analysis will be proposed in order to identify which factors influence degrees, repertoires and styles of participation in the realm of non-conventional politics and civic commitment.

On the micro level, participation is influenced by individual resources (time, money, civic skills) and socio-economic status (Brady et al., 1995: 27194), but also by the personal history of mobility. These variables interact in influencing other relevant variables, such as linguistic knowledge and understanding of the political system of the country of residence. In brief, we expect cognitively mobilised citizens to be more equipped to orient and adapt themselves to a different political system.

On the macro level, relevant variables are the political opportunity structure, both nationally and locally (Ireland, 1994; Fennema and Tillie, 1999; Koopmans and Statham, 2000).

The political opportunity structure is defined as "the receptivity and vulnerability of the political system to the action of contesting groups and the degree and the type of access to institutions" (Danese, 2001). The country of origin affects political behaviours in different ways: influencing the political socialisation and the political culture of movers also in the long term (Marelman, 1986; 
Glass at al., 1996), as well as providing transnational institutional resources of mobilisation (Østergaard-Nielsen, 2003).

Finally, we expect the meso dimension, concerning the role of organisations and transnational and local networks of co-nationals (Jacobs and Tillie, 2004; Ryan et al. 2008), to be relevant, especially for movers equipped with fewer social, economic and cultural resources, living their experience in the more traditional frame of migration. This level of analysis corresponds to traditional research on migrants. Particular attention must be paid to the formation of social capital in a new social context, as associative and informal networks can play a vital part in view of obtaining information and support for social, economic and cultural integration at different stages of the migration experience (Moya, 2005; Schrover and Vermeulen, 2005).

Participation in collective activities, such as engaging in protests, or working for organisations, presumes the existence of collective identities and integration in social networks, besides being more time-consuming and demanding than voting, which does not require social networking (De Rooij, 2011: 470). Yet, for EU movers, and especially for those equipped with fewer individual resources (education, linguistic skills, money, time), voting can turn into a highly expensive form of participation, being dependent on formal and informal barriers, while collective action can be facilitated by integration in informal networks (Verba et al. 1995).

In the case of intra-EU mobility, we will pay attention to the difference between "new" and "old" European countries: consolidated and younger democracies, differentiated in terms of institutional system, civil society structure, and spread of non-conventional participation (Haerpfer, 2002). As Letki points out, in communist regimes before 1989 only protest-like forms of participation directed 'against the state' (such as mass strikes and demonstrations) were available for expressing citizens' opinions (Letki, 1995). Therefore, many researchers thought that this form of participation would produce low conventional participation among citizens of post-communist countries (Miller, 1993). As confirmed by the comparative research coordinated by Torcall and Montero, "if in western countries decrease in conventional participation is equilibrated by the increase in non-conventional and in social participation, in many new democracies, higher levels of political disaffection do not lead to higher levels of non-conventional political actions, but rather to generally low levels of political involvement" (Torcal and Montero, 2006: 15). Because of the inherited democratic values and participative attitudes, we expect, at least in the short term, a lower involvement among EU movers coming from a new democracy. 


\section{METHODS AND GOALS}

We have explored the data gathered by the MOVEACT ("All Citizens Now": Intra-EU Mobility and Political Participation of English, Germans, Poles and Romanians in Western and Southern European Cities; a project funded by the European Commission, Directorate-General of Justice, Freedom and Security), that allows for a comparison of the political behaviour of "old Europeans" (British and Germans), and "new" Europeans" (Poles and Romanians), resident in Greece, France, Italy and Spain, and the data from the project "La participación Política como candidatos de los residentes europeos en España" (Ref. CSO2012-32930, Ministry of Economy and Competitiveness, Spain).

The survey data from the MOVEACT project offers quantitative information on the social and political participation of EU movers through a random telephone survey, based on a standardised questionnaire. The target population were British, German, Polish and Romanian citizens living abroad in France, Greece, Italy and Spain. All respondents had to have the nationality of the country of origin (COO), be settled in the COR as adults (aged 18 or more) before January 2011, and reside in the COR for at least six months during 2011. Under these conditions, 125 people of each of these four nationalities were interviewed, for a total of 500 cases per country of residence and 2000 individuals for the four target countries, with a sampling error of $\pm 2.24 \%$ with a confidence level of $95.5 \%$ (two sigma) and $\mathrm{P}=\mathrm{Q}$.

The sampling and screening of respondents combined telephone registers with linguistic information on names and surnames, in a similar way to the innovative technique developed in the PIONEUR EU project (V Framework Programme) - Cfr Recchi and Favell, 2013). Bilingual interviewers, most of them having the required nationality, conducted the interviews. Additional "onomastic" and "snowball" sampling was made to complete the field when required to balance respondents by gender (with a maximum of $10 \%$ of each national sample).

The goal is to identify the factors that influence non-conventional forms of participation. Which variables determine the relation of EU movers with non-conventional politics and civic commitment? How does mobility interact with individual characteristics and previous experience of participation? What are the roles played by the degree of integration and contextual factors? The analysis would be very limited if only non-conventional participation in the COR were studied, without comparing it to the participation in the COO. To this end, we introduce a dynamic element, distinguishing whether respondents stopped participating or began to participate after the change of residence. We can thus single out context-specific participation. 
On the other hand, considering the diversity of the target population, this paper aims to find out what all national groups of migrants in all countries of destination have in common that significantly explains non-conventional political participation.

The overall goal is to verify the hypothesis of an "elective affinity" between mobility and spread of non-conventional participation. Is the EU really a laboratory of the redefinition of politics, where movers play a leading role? And what is the relation between transnationalisation, cognitive mobilisation and spread of non-conventional participation?

\section{RESULTS AND DISCUSSION}

\subsection{The dynamics of participation and spatial mobility}

The non-conventional political mobilisation of mobile citizens can be considered from a comparative point of view, according to their behaviour in the country of origin and their behaviour in the country of residence.

To do this, we will use a variable of participation built from other two variables (participation in demonstrations + signing a letter to a politician). The classification of the different forms of political participation in the categories of conventional and non-conventional political participation has been subject to much controversy since the first development of Verba and Nie (1972). In this paper, we consider that the difference between both types of participation does not depend on the degree of radical political actions, defined from the degree of formalisation in the political system. We consider, from a structural-functional view, that the division can be established between, on the one hand, institutional demands, usually scheduled in time (such as elections), and on the other hand the demands of citizens to democratic institutions, usually without programming or temporal foresight. This participation, which is not institutionalised as a system-programmed demand (or as a substantial part of its legitimation), is what we call non-conventional (also called non-institutional by other authors). While conventional political channels are instruments with an institutional character, in the sense of being defined as part of the legitimation of the political system, unconventional channels have an origin from below because they meet certain specific needs and demands of civil society. This taxonomy of citizen participation has been used in recent European projects on political participation (PIDOP, 2012). In this Policy paper, the following examples of conventional and non-conventional participation are defined: "Examples of conventional political participation: voting, membership of a political party, running for political elections, working on political election 
campaigns for candidates or parties, making donations to political parties, trying to persuade others to vote. Examples of non-conventional political participation: membership of groups or campaigning organizations with a political focus, participating in protests, demonstrations and marches, signing petitions, writing letters or emails to politicians or public officials, writing articles or blogs with a political content for the media, participating in fundraising events for a political cause".

We can observe the behaviour of this variable of participation according to four possibilities of participation over time (never participated, has always participated, stopped participating when migrated, and started participating in the destination country when migrated).

Table 1. Operationalization of the variable Dynamics of participation

\begin{tabular}{|c|c|c|c|}
\hline & & \multicolumn{2}{|c|}{ Country of Destination } \\
\hline & & Participate & Not participate \\
\hline \multirow{2}{*}{$\begin{array}{c}\text { Country of } \\
\text { origin }\end{array}$} & Participate & Always participate & Stopped participation \\
\hline & Not participate & B egan to participate & Never participate \\
\hline
\end{tabular}

The aim is to detect either continuity or rupture. Table 2 shows the structure of participation by migrant groups and country of destination.

In structural terms, we are unable to find a high motivation for political participation of migrants in either the country of origin or the country of residence. For all of the groups, political participation (signing a petition and sending letters to politicians) is never higher than $50 \%$. The maximum and minimum are achieved by Germans and Romanians respectively.

In this sense, the data confirms a low participative aptitude, especially among new EU citizens, while the Germans are confirmed as being more participative (or perhaps the least disaffected). But to some extent we can see how, for all groups of migrants, mobility implies a change in the motivation for unconventional political action. In all cases where a variation occurs, it is more likely to be due to the emergence of rather than the decline in political participation.

We can see that, in the case of British migrants, their behaviour in unconventional political participation is almost invariant for the different countries to which they have migrated. Most of them continue their usual "non-participation", around $63 \%$ of the group, followed by an activation of participation (27\%), those who never participate (5.6\%) or cease to participate after installed in the country of destination (3.4\%). However, the other three migrant groups 
Table 2. Dynamics of participation and country of residence

\begin{tabular}{|c|c|c|c|c|c|c|}
\hline \multirow[t]{2}{*}{ Nationality } & & \multicolumn{4}{|c|}{ Dataset source } & \multirow[b]{2}{*}{ Total } \\
\hline & & Greece & France & Italy & Spain & \\
\hline \multirow[t]{5}{*}{ United Kingdom } & Never participated & $68.8 \%$ & $57.8 \%$ & $69.0 \%$ & $58.4 \%$ & $63.3 \%$ \\
\hline & Stopped participating & $3.2 \%$ & $3.0 \%$ & $1.7 \%$ & $5.6 \%$ & $3.4 \%$ \\
\hline & B egan to participate & $24.0 \%$ & $31.9 \%$ & $25.9 \%$ & $28.8 \%$ & $27.7 \%$ \\
\hline & Always participate & $4.0 \%$ & $7.4 \%$ & $3.4 \%$ & $7.2 \%$ & $5.6 \%$ \\
\hline & Total & $100.0 \%$ & $100.0 \%$ & $100.0 \%$ & $100.0 \%$ & $100.0 \%$ \\
\hline \multirow[t]{5}{*}{ Germany } & Never participated & $33.3 \%$ & $64.6 \%$ & $62.9 \%$ & $60.8 \%$ & $55.5 \%$ \\
\hline & Stopped participating & $4.1 \%$ & $3.9 \%$ & $4.0 \%$ & $4.0 \%$ & $4.0 \%$ \\
\hline & B egan to participate & $41.5 \%$ & $21.3 \%$ & $25.8 \%$ & $22.4 \%$ & $27.7 \%$ \\
\hline & Always participate & $21.1 \%$ & $10.2 \%$ & $7.3 \%$ & $12.8 \%$ & $12.8 \%$ \\
\hline & Total & $100.0 \%$ & $100.0 \%$ & $100.0 \%$ & $100.0 \%$ & $100.0 \%$ \\
\hline \multirow[t]{5}{*}{ Poland } & Never participated & $40.0 \%$ & $78.0 \%$ & $71.0 \%$ & $75.8 \%$ & $66.2 \%$ \\
\hline & Stopped participating & $6.4 \%$ & $1.6 \%$ & $1.6 \%$ & $1.6 \%$ & $2.8 \%$ \\
\hline & B egan to participate & $28.8 \%$ & $17.3 \%$ & $20.2 \%$ & $14.5 \%$ & $20.2 \%$ \\
\hline & Always participate & $24.8 \%$ & $3.1 \%$ & $7.3 \%$ & $8.1 \%$ & $10.8 \%$ \\
\hline & Total & $100.0 \%$ & $100.0 \%$ & $100.0 \%$ & $100.0 \%$ & $100.0 \%$ \\
\hline \multirow[t]{5}{*}{ Romania } & Never participated & $93.7 \%$ & $81.0 \%$ & $81.3 \%$ & $88.0 \%$ & $86.0 \%$ \\
\hline & Stopped participate & $3.1 \%$ & $4.8 \%$ & $.8 \%$ & $4.0 \%$ & $3.2 \%$ \\
\hline & B egan to participate & $1.6 \%$ & $12.7 \%$ & $12.2 \%$ & $4.8 \%$ & $7.8 \%$ \\
\hline & Always participated & $1.6 \%$ & $1.6 \%$ & $5.7 \%$ & $3.2 \%$ & $3.0 \%$ \\
\hline & Total & $100.0 \%$ & $100.0 \%$ & $100.0 \%$ & $100.0 \%$ & $100.0 \%$ \\
\hline
\end{tabular}

Source: Author's own research on MOVEACT data

(Germans, Poles and Romanians) show a different dynamic in the case of Greece. Keeping each profile group in the other three countries, we found an increase in "started participating" among Germans and Poles in Greece, and in the case of Romanians, in France and Italy.

In dynamic terms for the different nationalities, Romanians in France and Italy have been mobilised more than in Spain and Greece. In France and Italy these mobilisations are likely to respond to a threat to their freedom of move- 
ment as EU citizens after similar legislative and administrative initiatives (expulsion): the "safety plan" adopted in Italy in 2008 and, in France, the deportations in July 2010. In Greece, the increased participation of Poles and Germans may be due to the intensity of the economic and social crisis in this country and the dimension of social protest. This increases the likelihood of these groups participating in a demonstration.

Romanians are the group with lowest overall participation. However, the Poles (also new European citizens) show greater experience in unconventional demonstrations in their country of origin. In the case of Romanian migrants, non-participation is not only a consequence of mobility: they did not participate in their country of origin either. The dimension of democratic tradition (political culture) and the experience in the transition to democracy is clearly shown in overall participation levels. We could conclude that the democratic tradition of origin (political culture) shapes participation independently of one's place of residence.

The degree of participation is also significantly affected by elements that express integration, understood as knowledge of the social environment in which the migrants are living, such as the knowledge of the language or having friends in the country of destination. Other variables that affect the degree of participation are gender (generally greater participation for men), age (greater activation of participation at older ages), the migration period (in the most recent period there is a higher percentage of persons who have never participated, and more activation in migrants who arrived before the 90s, except in the case of the Poles, for whom activation was highest in the migration period 1990-2003), the class position (greater activation in classes I and II, especially Romanians) and education (higher participation among those with college education, in terms of when they start and whether they keep participating).

\subsection{Cognitive Political Mobilisation and political socialisation}

The political culture of origin has an important role in motivation for political participation. It is present in the whole process of citizens' political socialisation. The different political culture of origin, as well as the experiences lived in the process of political socialisation (political crises, democratic transitions, mobilisation of social resistance) are reflected in cognitive political mobilisation.

We have created an index of CPM, resulting from the combination of the answers to two questions: "frequency of discussing politics with the family" and "interest in national political news of the country of residence." 
Table 3. Cognitive Mobilisation Index

\begin{tabular}{l|l|l|l}
\hline Cognitive mobilisation & Persuade & & Discuss \\
\hline \multirow{2}{*}{ Low } & Rarely, never or DK/NA & and & Never or DK/NA \\
\hline \multirow{2}{*}{ Medium low } & Rarely, never or DK/NA & and & Occasionally \\
\cline { 2 - 4 } & Often, fron time to time & and & Never or DK/NA \\
\hline \multirow{2}{*}{ Medium high } & Rarely, never or DK/NA & and & Frequently \\
\cline { 2 - 4 } & Often, from time to time & and & Occasionally \\
\hline \multirow{2}{*}{ High } & Often, from time to time & and & Frequently \\
\hline
\end{tabular}

Source: Alaminos-Penalva (2012), from Eurobarometer (adapted from Schmitt and Scholz, 2005). Note: DN/NA = Don't Know / Don't Answer

Cognitive Political Mobilisation is an indirect way to determine the degree of motivation for political participation (Alaminos and Penalva, 2012). This index, adapted to this population, incorporates the interest in the news of the destination country as a measure of political and cultural competence (qualification for understanding political affairs, local language) and as a measure of the interest in the political affairs of the country of destination.

Germans show a higher degree of CPM, followed by Poles, the British and Romanians. In the case of British movers, this result can be explained by the type of migration they experience. Most of them, especially in Spain and Italy, are elderly experiencing a post-retirement long-term mobility. They live in new segregated settlements and they are less permeable to the society of residence.

The sociodemographic profile of Poles (whose migration is mainly due to labour and economic reasons) and their history of political involvement in Polish political culture since before the transition to democracy are different. Therefore, they get high and average scores in cognitive mobilisation; higher in all cases than those of citizens of Romanian origin. We must emphasise this fact, because those remarkable differences between Romanians and Poles occur even though they joined the EU at a similar time (new Europeans) and both have a communist political tradition.

In general, cognitive political mobilisation is different for each country. However, the relationship between the rate of cognitive political mobilisation and the participation dynamics is evident, as can be seen for migrant groups in Table 5 (Polish, Romanian, British or German) and also when grouped by recipient country in Table 6 (Spain, France, Italy and Greece). For all tables, 
Table 4. Discuss politics with family and interest in national political news of the country of residence

\begin{tabular}{|c|c|c|c|c|c|c|}
\hline \multirow[t]{2}{*}{ Nationality } & \multirow[t]{2}{*}{ CPM } & \multicolumn{4}{|c|}{ Dataset source } & \multirow[t]{2}{*}{ Total } \\
\hline & & Greece & France & Italy & Spain & \\
\hline \multirow[t]{5}{*}{ United Kingdom } & Very high & $24.8 \%$ & $18.7 \%$ & $10.1 \%$ & $14.5 \%$ & $17.1 \%$ \\
\hline & High & $37.2 \%$ & $44.0 \%$ & $26.9 \%$ & $26.6 \%$ & $33.9 \%$ \\
\hline & Low & $27.3 \%$ & $27.6 \%$ & $29.4 \%$ & $24.2 \%$ & $27.1 \%$ \\
\hline & very low & $10.7 \%$ & $9.7 \%$ & $33.6 \%$ & $34.7 \%$ & $21.9 \%$ \\
\hline & Total & $100.0 \%$ & $100.0 \%$ & $100.0 \%$ & $100.0 \%$ & $100.0 \%$ \\
\hline \multirow[t]{5}{*}{ Germany } & Very high & $48.4 \%$ & $33.9 \%$ & $49.2 \%$ & $43.2 \%$ & $43.6 \%$ \\
\hline & High & $35.2 \%$ & $41.7 \%$ & $32.3 \%$ & $25.6 \%$ & $33.7 \%$ \\
\hline & Low & $9.8 \%$ & $21.3 \%$ & $12.9 \%$ & $24.0 \%$ & $17.1 \%$ \\
\hline & very low & $6.6 \%$ & $3.1 \%$ & $5.6 \%$ & $7.2 \%$ & $5.6 \%$ \\
\hline & Total & $100.0 \%$ & $100.0 \%$ & $100.0 \%$ & $100.0 \%$ & $100.0 \%$ \\
\hline \multirow[t]{5}{*}{ Poland } & Very high & $22.4 \%$ & $25.4 \%$ & $20.0 \%$ & $16.9 \%$ & $21.2 \%$ \\
\hline & High & $46.4 \%$ & $43.7 \%$ & $40.0 \%$ & $34.7 \%$ & $41.2 \%$ \\
\hline & Low & $25.6 \%$ & $15.9 \%$ & $23.2 \%$ & $34.7 \%$ & $24.8 \%$ \\
\hline & very low & $5.6 \%$ & $15.1 \%$ & $16.8 \%$ & $13.7 \%$ & $12.8 \%$ \\
\hline & Total & $100.0 \%$ & $100.0 \%$ & $100.0 \%$ & $100.0 \%$ & $100.0 \%$ \\
\hline \multirow[t]{4}{*}{ Romania } & Very high & $14.3 \%$ & $22.2 \%$ & $13.7 \%$ & $8.9 \%$ & $14.8 \%$ \\
\hline & High & $21.4 \%$ & $49.2 \%$ & $41.1 \%$ & $25.2 \%$ & $34.3 \%$ \\
\hline & Low & $42.1 \%$ & $22.2 \%$ & $22.6 \%$ & $37.4 \%$ & $31.1 \%$ \\
\hline & very low & $22.2 \%$ & $6.3 \%$ & $22.6 \%$ & $28.5 \%$ & $19.8 \%$ \\
\hline Total & & $100.0 \%$ & $100.0 \%$ & $100.0 \%$ & $100.0 \%$ & $100.0 \%$ \\
\hline
\end{tabular}

Source: Author's own research on MOVEACT data 
the chi square test shows no independence between dynamics of participation and cognitive political mobilisation. Therefore, the contingency coefficient shows that both variables are associated and have their own profiles. This is fully consistent with the profiles in the dynamics of mobilisation, given the attitudinal root of the variable CPM that has been measured as "talk politics" and "show interest in politics", and to the extent that the dynamic variable of participation expresses the interaction of CPM with social integration.

Table 5. Dynamics of participation as cognitive political mobilisation (dichotomous) by country of origin \% of CPM

\begin{tabular}{|c|c|c|c|c|}
\hline \multirow[t]{2}{*}{ Nationality } & \multirow[t]{2}{*}{ Dynamics of participation } & \multicolumn{2}{|l|}{$\mathrm{CPM}$} & \multirow[t]{2}{*}{ Total } \\
\hline & & Low & High & \\
\hline \multirow[t]{5}{*}{ United Kingdom } & Never participated & $75.1 \%$ & $51.8 \%$ & $63.2 \%$ \\
\hline & Stopped participating & $2.1 \%$ & $4.8 \%$ & $3.5 \%$ \\
\hline & B egan to participate & $19.5 \%$ & $35.5 \%$ & $27.6 \%$ \\
\hline & Always participate & $3.3 \%$ & $8.0 \%$ & $5.7 \%$ \\
\hline & Total & $100.0 \%$ & $100.0 \%$ & $100.0 \%$ \\
\hline \multirow[t]{5}{*}{ Germany } & Never participated & $77.0 \%$ & $49.3 \%$ & $55.7 \%$ \\
\hline & Stopped participating & $3.5 \%$ & $4.2 \%$ & $4.0 \%$ \\
\hline & B egan to participate & $12.4 \%$ & $32.0 \%$ & $27.5 \%$ \\
\hline & Always participated & $7.1 \%$ & $14.4 \%$ & $12.8 \%$ \\
\hline & Total & $100.0 \%$ & $100.0 \%$ & $100.0 \%$ \\
\hline \multirow[t]{5}{*}{ Poland } & Never participated & $79.1 \%$ & $58.2 \%$ & $66.1 \%$ \\
\hline & Stopped participating & $2.7 \%$ & $2.9 \%$ & $2.8 \%$ \\
\hline & B egan to participate & $12.3 \%$ & $25.1 \%$ & $20.3 \%$ \\
\hline & Always participated & $5.9 \%$ & $13.8 \%$ & $10.8 \%$ \\
\hline & Total & $100.0 \%$ & $100.0 \%$ & $100.0 \%$ \\
\hline \multirow[t]{5}{*}{ Romania } & Never participated & $91.7 \%$ & $79.9 \%$ & $85.9 \%$ \\
\hline & Stopped participating & $2.8 \%$ & $3.7 \%$ & $3.2 \%$ \\
\hline & B egan to participate & $4.4 \%$ & $11.5 \%$ & $7.9 \%$ \\
\hline & Always participating & $1.2 \%$ & $4.9 \%$ & $3.0 \%$ \\
\hline & Total & $100.0 \%$ & $100.0 \%$ & $100.0 \%$ \\
\hline
\end{tabular}

Source: Author's own research on MOVEACT data 
Table 6. Dynamics of participation as cognitive political mobilisation (dichotomous) by country of residence \% of CPM

\begin{tabular}{|c|c|c|c|c|}
\hline \multicolumn{2}{|c|}{ Country of residence } & \multicolumn{3}{|l|}{$\mathrm{CPM}$} \\
\hline & & \multirow{2}{*}{$\begin{array}{l}\text { Low } \\
80.0 \%\end{array}$} & \multirow{2}{*}{$\begin{array}{l}\text { High } \\
46.3 \%\end{array}$} & \multirow{2}{*}{$\begin{array}{l}\text { Total } \\
58.9 \%\end{array}$} \\
\hline Greece & Never participated & & & \\
\hline & Stopped participating & $2.2 \%$ & $5.5 \%$ & $4.3 \%$ \\
\hline & B egan to participate & $10.8 \%$ & $31.9 \%$ & $24.0 \%$ \\
\hline & Always participated & $7.0 \%$ & $16.3 \%$ & $12.8 \%$ \\
\hline & Total & $100.0 \%$ & $100.0 \%$ & $100.0 \%$ \\
\hline \multirow[t]{5}{*}{ France } & Never participated & $80.1 \%$ & $65.6 \%$ & $70.1 \%$ \\
\hline & Stopped participating & $2.6 \%$ & $3.7 \%$ & $3.3 \%$ \\
\hline & B egan to participate & $14.7 \%$ & $23.7 \%$ & $20.9 \%$ \\
\hline & Always participated & $2.6 \%$ & $7.0 \%$ & $5.7 \%$ \\
\hline & Total & $100.0 \%$ & $100.0 \%$ & $100.0 \%$ \\
\hline \multirow[t]{5}{*}{ Italy } & Never participated & $85.5 \%$ & $61.0 \%$ & $71.2 \%$ \\
\hline & Stopped participating & $.5 \%$ & $3.2 \%$ & $2.1 \%$ \\
\hline & B egan to participate & $12.5 \%$ & $26.6 \%$ & $20.7 \%$ \\
\hline & Always participated & $1.5 \%$ & $9.2 \%$ & $6.0 \%$ \\
\hline & Total & $100.0 \%$ & $100.0 \%$ & $100.0 \%$ \\
\hline \multirow[t]{5}{*}{ Spain } & Never participated & $80.6 \%$ & $60.5 \%$ & $70.7 \%$ \\
\hline & Stopped participating & $4.8 \%$ & $2.9 \%$ & $3.8 \%$ \\
\hline & B egan to participate & $10.7 \%$ & $24.7 \%$ & $17.6 \%$ \\
\hline & Always participating & $4.0 \%$ & $11.9 \%$ & $7.9 \%$ \\
\hline & Total & $100.0 \%$ & $100.0 \%$ & $100.0 \%$ \\
\hline
\end{tabular}

Source: Author's own research on MOVEACT data 
We can see how the degree of cognitive political mobilisation globally explains the motivation or lack of motivation to participate, in any category of continuity (never / always) or discontinuity (start /stop). Thus, CPM affects participation in both cases, when participation is continuous or discontinuous.

Connecting it to the contextual factors of the place of residence, we can say that migrants with a high CPM are more likely to engage in political action. This participatory potential would be activated in conflictive situations which could possibly lead to protests, both for issues affecting them as a group (loss of rights, abuse, discrimination) and for issues affecting the general population. On the other hand, it is important to note that political socialisation is the main source of this motivation for political action, measured in the CPM index. We refer to one of the main agents of political socialisation: parents. The frequency of talking politics in the family environment when individuals were children explains CPM. The two approaches, by migrant group or by destination country, clearly show such dependence. Especially high are the asymmetric coefficients with CPM depending on socialisation.

Table 7. CPM by political socialisation in the family and migrant group

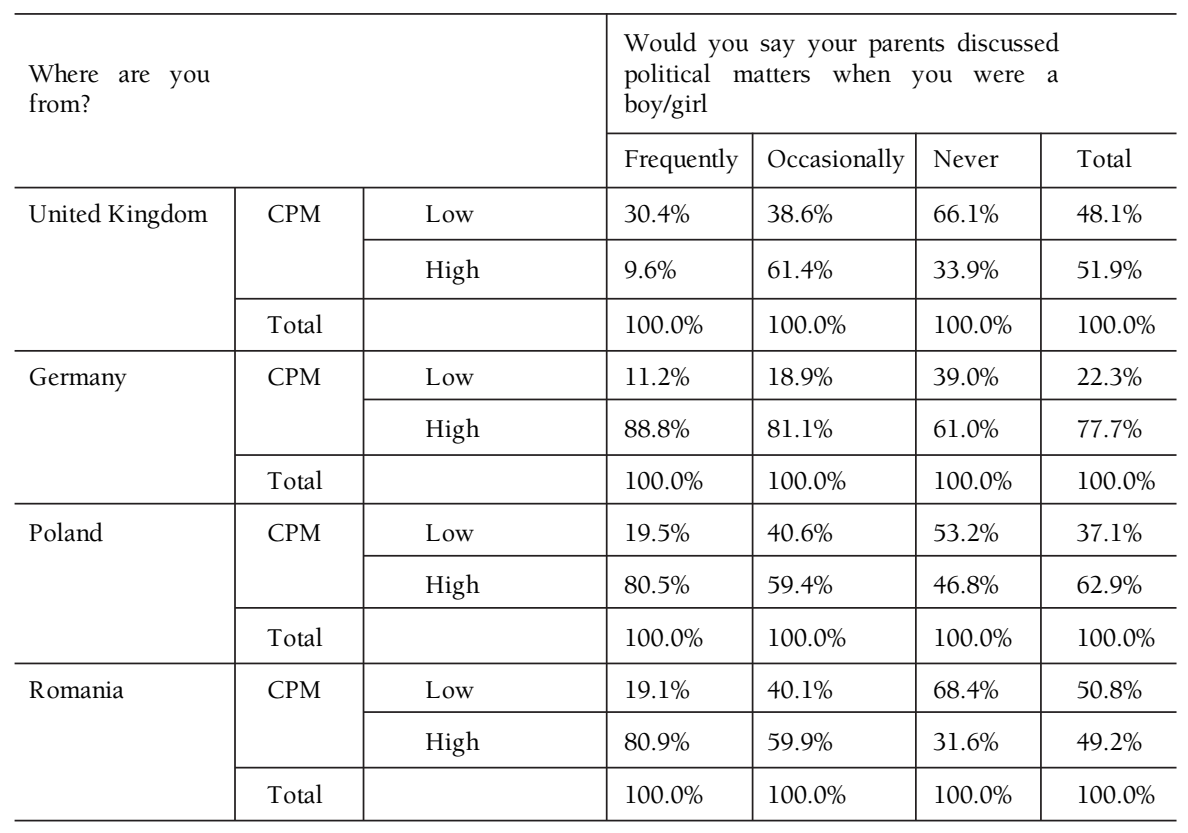

Source: Author's own research on MOVEACT data 
Table 8. CPM by socialisation and country of residence of the migrant group

\begin{tabular}{|c|c|c|c|c|c|c|}
\hline \multicolumn{3}{|c|}{ Dataset source } & \multicolumn{4}{|c|}{$\begin{array}{l}\text { Would you say your parents discussed } \\
\text { political matters when you were a } \\
\text { boy/girl }\end{array}$} \\
\hline & & & \multirow{2}{*}{$\begin{array}{l}\text { Frequently } \\
19.2 \%\end{array}$} & \multirow{2}{*}{$\frac{\text { Occasionally }}{29.5 \%}$} & \multirow{2}{*}{$\begin{array}{l}\text { Never } \\
62.3 \%\end{array}$} & \multirow{2}{*}{$\frac{\text { Total }}{37.8 \%}$} \\
\hline Greece & $\mathrm{CPM}$ & Low & & & & \\
\hline & & High & $80.8 \%$ & $70.5 \%$ & $37.7 \%$ & $62.2 \%$ \\
\hline & Total & & $100.0 \%$ & $100.0 \%$ & $100.0 \%$ & $100.0 \%$ \\
\hline \multirow[t]{3}{*}{ France } & \multirow[t]{2}{*}{$\mathrm{CPM}$} & Low & $16.9 \%$ & $25.1 \%$ & $50.7 \%$ & $30.5 \%$ \\
\hline & & High & $83.1 \%$ & $74.9 \%$ & $49.3 \%$ & $69.5 \%$ \\
\hline & Total & & $100.0 \%$ & $100.0 \%$ & $100.0 \%$ & $100.0 \%$ \\
\hline \multirow[t]{3}{*}{ Italy } & \multirow[t]{2}{*}{$\mathrm{CPM}$} & Low & $16.4 \%$ & $39.9 \%$ & $61.3 \%$ & $40.0 \%$ \\
\hline & & High & $83.6 \%$ & $60.1 \%$ & $38.7 \%$ & $60.0 \%$ \\
\hline & Total & & $100.0 \%$ & $100.0 \%$ & $100.0 \%$ & $100.0 \%$ \\
\hline \multirow[t]{3}{*}{ Spain } & \multirow[t]{2}{*}{$\mathrm{CPM}$} & Low & $24.2 \%$ & $49.4 \%$ & $61.8 \%$ & $50.4 \%$ \\
\hline & & High & $75.8 \%$ & $50.6 \%$ & $38.2 \%$ & $49.6 \%$ \\
\hline & Total & & $100.0 \%$ & $100.0 \%$ & $100.0 \%$ & $100.0 \%$ \\
\hline
\end{tabular}

Source: Author's own research on MOVEACT data

\subsection{The dimension of social integration}

As seen above, cognitive political mobilisation comprehensively explains the participation of migrants. For all populations studied, the probability of unconventional political participation depends on a high cognitive mobilisation. In turn, this is the outcome of the socialisation process and the political culture of the country of origin.

Nevertheless, there are other variables that should be incorporated into the analysis to explain the discontinuities in the dynamics of participation in the mobility experience. These two variables point to the degree of integration into the host society. The first (membership of associations) has a strong sociopolitical character (integration through associative networks) and opens the possibility of coordinated collective action. The second (expectation that they will stay or return to the country of origin) allows us to observe the socio-cultural dimension of integration and shows a psychological attitude (in which social space respondents will be located in the future) that in terms of political participation may lead to a proactive orientation regarding political mobilisation. As we can see, for all countries of residence and all migrant groups, these two variables affect the dynamics of participation. 
As for the membership of associations, the number of associations to which one belongs explains the beginning (Start) of unconventional participation. Regression analysis shows that this is true for all nationalities.

Table 9. Regression analysis (dependent variable: start to participate)

\begin{tabular}{|c|c|c|c|c|c|c|}
\hline \multirow[t]{2}{*}{$\begin{array}{l}\text { Where are you } \\
\text { from? }\end{array}$} & & \multicolumn{2}{|c|}{$\begin{array}{l}\text { Unstandardized } \\
\text { Coefficients }\end{array}$} & \multirow{2}{*}{$\begin{array}{l}\text { Standardized } \\
\text { Coefficients } \\
\text { Beta }\end{array}$} & \multirow[t]{2}{*}{$\mathrm{t}$} & \multirow[t]{2}{*}{ Sig. } \\
\hline & & $\mathrm{B}$ & Error típ. & & & \\
\hline \multirow[t]{3}{*}{ United Kingdom } & (Constant) & .301 & .054 & & 5.621 & .000 \\
\hline & $\begin{array}{l}\text { Number of } \\
\text { associations }\end{array}$ & .059 & .012 & .217 & 4.924 & .000 \\
\hline & $\begin{array}{l}\text { Language knowledge } \\
\text { now }\end{array}$ & -.051 & .018 & -.127 & -2.894 & .004 \\
\hline \multirow[t]{3}{*}{ Germany } & (Constant) & .351 & .054 & & 6.552 & .000 \\
\hline & $\begin{array}{l}\text { Number of } \\
\text { associations }\end{array}$ & .027 & .013 & .091 & 1.992 & .047 \\
\hline & $\begin{array}{l}\text { Language knowledge } \\
\text { now }\end{array}$ & -.060 & .021 & -.133 & -2.928 & .004 \\
\hline \multirow[t]{2}{*}{ Poland } & (Constant) & .159 & .048 & & 3.280 & .001 \\
\hline & $\begin{array}{l}\text { Number of } \\
\text { associations }\end{array}$ & .059 & .014 & .186 & 4.123 & .000 \\
\hline \multirow[t]{2}{*}{ Romania } & (Constant) & .076 & .033 & & 2.256 & .025 \\
\hline & $\begin{array}{l}\text { Number of } \\
\text { associations }\end{array}$ & .036 & .008 & .206 & 4.537 & .000 \\
\hline
\end{tabular}

Source: Author's own research on MOVEACT data

Table 10. Where will you live in five years * STOP/START non-conventional participation (by nationality) \% of WHERE WILL LIVE IN FIVE YEARS

\begin{tabular}{|c|c|c|c|c|c|}
\hline \multirow[t]{2}{*}{$\begin{array}{l}\text { Where are you } \\
\text { from? }\end{array}$} & \multirow{2}{*}{\multicolumn{2}{|c|}{ Where will live in five years }} & \multicolumn{2}{|c|}{ STOP/START } & \multirow[t]{2}{*}{ Total } \\
\hline & & & & 1 & \\
\hline \multirow[t]{3}{*}{ United Kingdom } & & $\mathrm{COO}$ & $20.0 \%$ & $80.0 \%$ & $100.0 \%$ \\
\hline & & COR & $9.8 \%$ & $90.2 \%$ & $100.0 \%$ \\
\hline & Total & & $10.5 \%$ & $89.5 \%$ & $100.0 \%$ \\
\hline \multirow[t]{3}{*}{ Germany } & & $\mathrm{COO}$ & $50.0 \%$ & $50.0 \%$ & $100.0 \%$ \\
\hline & & COR & $8.3 \%$ & $91.7 \%$ & $100.0 \%$ \\
\hline & Total & & $10.4 \%$ & $89.6 \%$ & $100.0 \%$ \\
\hline \multirow[t]{3}{*}{ Poland } & & $\mathrm{COO}$ & $40.0 \%$ & $60.0 \%$ & $100.0 \%$ \\
\hline & & COR & $3.0 \%$ & $97.0 \%$ & $100.0 \%$ \\
\hline & Total & & $9.9 \%$ & $90.1 \%$ & $100.0 \%$ \\
\hline \multirow[t]{3}{*}{ Romania } & & $\mathrm{COO}$ & $100.0 \%$ & & $100.0 \%$ \\
\hline & & COR & $26.3 \%$ & $73.7 \%$ & $100.0 \%$ \\
\hline & Total & & $31.7 \%$ & $68.3 \%$ & $100.0 \%$ \\
\hline
\end{tabular}

Source: Author's own research on MOVEACT data 
On the other hand, future projections of migrants largely explain the dynamics of participation in mobility. It is also the variable that could allow an operational distinction between "migrants" (those who intend to return to the country of origin) and "citizens" (those who develop their civic dimension in the destination country). The prospect of living in the country of destination for the next five years determines the start of unconventional participation. For all nationalities, over $90 \%$ of cases whose experience of migration brought a change in their political behaviour did so because they initiated their unconventional political activity then. In the case of the British participation is high in any case.

Table 11. Where will you live in five years * STOP/START non-conventional participation (by country of residence) \% of WHERE WILL LIVE IN FIVE YEARS

\begin{tabular}{|c|c|c|c|c|c|}
\hline \multicolumn{3}{|c|}{ Dataset source } & \multicolumn{2}{|c|}{ STOP/START } & \multirow[t]{2}{*}{ Total } \\
\hline & & Where will live in five years & 0 & 1 & \\
\hline \multirow[t]{3}{*}{ Greece } & & $\mathrm{COO}$ & $31.3 \%$ & $68.8 \%$ & $100.0 \%$ \\
\hline & & $\mathrm{COR}$ & $12.0 \%$ & $88.0 \%$ & $100.0 \%$ \\
\hline & Total & & $14.8 \%$ & $85.2 \%$ & $100.0 \%$ \\
\hline \multirow[t]{3}{*}{ France } & & $\mathrm{COO}$ & $33.3 \%$ & $66.7 \%$ & $100.0 \%$ \\
\hline & & $\mathrm{COR}$ & $8.4 \%$ & $91.6 \%$ & $100.0 \%$ \\
\hline & Total & & $9.9 \%$ & $90.1 \%$ & $100.0 \%$ \\
\hline \multirow[t]{3}{*}{ Italy } & & $\mathrm{COO}$ & $100.0 \%$ & & $100.0 \%$ \\
\hline & & $\mathrm{COR}$ & $5.3 \%$ & $94.7 \%$ & $100.0 \%$ \\
\hline & Total & & $7.7 \%$ & $92.3 \%$ & $100.0 \%$ \\
\hline \multirow[t]{3}{*}{ Spain } & & $\mathrm{COO}$ & $50.0 \%$ & $50.0 \%$ & $100.0 \%$ \\
\hline & & $\mathrm{COR}$ & $13.7 \%$ & $86.3 \%$ & $100.0 \%$ \\
\hline & Total & & $18.1 \%$ & $81.9 \%$ & $100.0 \%$ \\
\hline
\end{tabular}

Source: Author's own research on MOVEACT data

\section{CONCLUSIONS}

Mobility is a characterising feature of contemporary society, and it is a key element in explaining social and political change. Spatial mobility promotes a redefinition of social experience beyond borders, and, therefore, also has a deep impact on participative repertoires. Non-conventional participation represents a distinct and autonomous field, and contributes to change in institutio- 
nal arrangements, generating a reciprocal interaction with institutional change. Non-conventional participation constitutes a great channel of change, promoting a bottom-up democratisation of European society.

In this article, we have tried to shade light on how a strategic segment of the European population, European movers, redefine their participative repertoires of non-conventional participation. Our analysis has confirmed that mobility does not affect the type and degree of participation in a simple way. Several variables interact in shaping the relation between movers and nonconventional participation. The interaction between these variables leads some movers to diminish their activation, other movers to follow a continuity in the change, and finally, other movers to increase and diversify their participative repertoires. Specifically, data analysis highlights three relevant dimensions to explain the unconventional political participation of EU movers: social integration, situational context and individual characteristics. Among the latter, cognitive mobilisation plays a crucial role.

We can summarise some major findings of our analysis:

1) Membership of associations and social networks facilitates the non-conventional mobilisation of EU movers;

2) EU movers' expectations of living in the country of residence (COR) in the future affects their non-conventional participation. These expectations heighten attention to the problems of the COR, through a proactive psychological orientation. For many movers, the destination country is the place where they have established a new economic and sociocultural life. It makes sense to be interested in public affairs, and to be mobilised at certain times, in the civic space where people and their descendants will live for good (or an indefinite future, at least).

3) The degree of Cognitive Political Mobilisation (CPM) of EU movers is the key aspect to understand their non-conventional participation, both in general and to give support to the changing patterns of participation after their change of residence. CPM creates a mobilisation potential that is activated at critical moments. Cognitive Political Mobilisation is revealed to be a key factor: cognitively mobilised movers generally have a personal history of social and political commitment. Experiencing mobility is not an obstacle to participation. On the contrary, they get even more involved. This happens because they are better equipped with the necessary resources to adapt to different political and social contexts. As a result, mobility, from the point of view of participation, turns into a positive-sum game, while for less skilled movers' mobility does not promote an enrichment of repertoires of participation, but a general detachment from politics. 
4) The degree of CPM of EU movers depends basically on family socialisation. An increasing degree of CPM is expected among movers who talked about politics in the family environment during their childhood. It is statistically significant that the more they talked about politics in their family, the greater their cognitive political mobilisation.

5) Together with political socialisation, the political culture represented by the democratic tradition of the country of origin is also a relevant variable that explains cognitive political mobilisation and participation levels. The culture of mobilisation in the country of origin explains the degree of nonconventional participation after the mobility experience.

Movers' mobilisation in the country of residence is influenced by certain conjuncture opportunities (conflictive political situations such as political and social crises, or threats to community residents) as well as by the opportunities that different destination countries offer for migrants. The problems that can affect immigrants are very diverse and common to the population where they live, but they are also specific. As non-conventional participation is, by its very nature, discontinuous and unstable, contingent and conjectural variables turned to be relevant in explaining political activation: when relevant issues are at stake, participation is higher.

Despite their legal status as citizens, many within the population of European movers seem to have features in common with the more traditional experience of migration. Migrants are traditionally less engaged than nationals and scarcely involved in the political life of the country of residence. Their participative repertoires are poorer and mainly oriented toward co-national communities and networks. We find nevertheless a significant portion of movers who experience mobility as truly European citizens. They do not merely use their right to free movement to pursue individual goals. Mobility also promotes a change in their civic and political aptitudes.

The comparison between nationalities, from this point of view, suggests that the lower participative aptitude of Eastern Europeans is indeed explainable by the different individual characteristics of this sub-population. Individual characteristics, and in particular cognitive mobilisation, influence the objective and the subjective self-characterisation of European movers as citizens or migrants, and, consequently, their approach toward non-conventional participation. In other words, cognitive political mobilisation acts as a filter, allowing European movers to move beyond the mere legal status and to be active in the making of a novel political transnationalisation which is conducted in the realm of non-conventional politics, even more than in the realm of conventional politics. Cognitive political mobilisation provides them with the cognitive tools 
to orient themselves in a complex environment, offering new opportunities and stimuli, which for less skilled movers turn out to be barriers.

Europeanisation does not mean only a change in scale - it also promotes a more general dynamic of political change, where change in individual values and attitudes foster change in participative repertoires. Mobile European citizens are protagonists of these dynamics: they contribute to Europeanisation from below as leading actors in experimenting with forms of non-nation-based participation, primarily in the realm of non-conventional participation.

\section{BIBLOGRAPHY}

Alaminos, A. and Penalva, C. (2012). "The Cognitive Mobilisation Index: Crisis and Political Generations". Sage Open 2 [http://sgo.sagepub.com/content/2/1/21582440 12440437].

Baglioni, L.G. and Recchi E. (2013). "La classe media va in Europa? Transnazionalismo e stratificazione sociale nell'Unione Europea". SocietàMutamentoPolitica 7, 47-69.

Barnes S.H. and Kaase M. (1979). Political Action: Mass Participation in Five Western Democracies. London-New York: Sage.

Brady, H. E.; Verba, S and; Schlozman, K. L. (1995). "Beyond SES: A Resource Model of Political Participation". American Political Science Review, 89, 271-94. https://doi.org/10.2307/2082425

Castells, M. (1996). The Rise of the Network Society, The Information Age: Economy, Society and Culture. Cambridge, MA- Oxford, UK: Blackwell.

Castles, S. and Miller, M.J. (2009). The Age Of Migrations. International Population Movement in the Modern World. London: Palgrave Macmillan.

Crouch, C. (2004). Postdemocracy. Oxford-New York: Oxford University Press.

Dalton, R.J. (1984). "Cognitive Mobilisation and Partisan Dealigment in Advanced Industrial Democracies". The Journal of Politics 46 (1): 264-284. https://doi.org/10. 2307/2130444

Danese, G. (2001). Participation Beyond Citizenship: Migrants'Associations in Italy and Spain. Patterns of Prejudice 35(1): 69-89. https://doi.org/10.1080/003132 201128811070

Della Porta, D. and Caiani, E. (2007). "Europeanization from Below? Social movements and Europe". Mobilization: An International Quarterly 12(1), 101-116.

De Rooij, E.A. (2011). "Patterns of Immigrant Political Participation: Explaining Differences in Types of Political Participation between Immigrants and the Majority Population in Western Europe". European Sociological Review 28(4), 470.

De Vreese, C.H. (2007). "The EU as a Public Sphere". Living Review on European Governance, 2.

Dryzek, J.S. and Holmes, L. (2002). Post-Communist Democratization. Cambridge: Cambridge University Press. https://doi.org/10.1017/CBO9780511492112 
Duchesne, S. (2008). "Waiting for a European Identity. Reflections on the Process of Identification with Europe". Perspectives on European Politics and Society 9(4), 397-410. https://doi.org/10.1080/15705850802416796

Fennema, M. and Tillie, J. (2004). "Civic Community, Political Participation and Political Trust of Ethnic Groups". Connections 24(1), 26-41.

Francés García, F. J. (2008). "El laberinto de la participación juvenil: estrategias de implicación ciudadana en la juventud". OBETS. Revista de Ciencias Sociales 2, 3551 https://doi.org/10.14198/OBETS2008.2.03

Glick Schiller, N.; Basch, L. and Szanton-Blanc, C. (1992). Towards a Transnational Perspective on Migration: Race, Class, Ethnicity, and Nationalism Reconsidered. New York: The New York Academy of Science.

Haerpfer, C.W. (2002). Democracy and Enlargement in Post-Communist Europe. The Democratization of the General Public in Fifteen Central and Eastern European Countries, 1991-1998. London-New York: Routledge.

Inglehart, R. (1970). "Cognitive Mobilisation and European identity". Comparative Politics 3(1), 45-70. https://doi.org/10.2307/421501

Inglehart, R. (1990). Culture Shift in Advanced Industrial Society. Princeton: Princeton University Press.

Ireland, P. (1994). Becoming Europe. Immigration, Integration and the Welfare State. New York: Columbia University Press.

Klandermans, B. (1997). The Social Psychology of Protest. Cambridge: Blackwell.

Koopmans, R. and Statham, P. (eds.) (2000). Challenging Immigration and Ethnic Relations Politics: Comparative European Perspectives. Oxford: Oxford University Press.

Letki, N. (2003). Explaining Political Participation in East-Central Europe: Social Capital, Democracy and the Communist Past. Oxford: Nuffield College Politics Working Paper 2.

Martiniello, M. (2006). "Political Participation, Mobilisation and Representation of Immigrants and their Offspring in Europe". In R. Bauböck, (ed.) Migration and Citizenship. Legal Status, Rights and Political Participation. Amsterdam: Amsterdam University Press, pp. 84.

Mau, S. (2010). European Societies. Mapping Structure and Change. Bristol: Policy Press.

Merelman, R. (1986). "Revitalizing political socialisation". In M.G. Hermann (ed.). Political Psychology: Contemporary Problems and Issues. San Francisco: Jossey-Bass, pp. 279-319.

Østergaard-Nielsen, E. (2003). International Migration and Sending Countries: Perceptions, Policies, and Transnational Relations. London: Palgrave McMillan. https://doi.org/10.1057/9780230512429

Milbrath, L.W. and Goel M. L. (1977). Political Participation. How and why do people get involved in politics? Chicago: Rand McNally.

Miller, R.F. (1993). The Developments of Civil Society in Communist Systems. Sydney: Ilen \& Unwin. 
Morales, L. and Giugni, M. (eds.) (2011). Social Capital, Political Participation and Migration in Europe, Making Multicultural Democracy Work? Basingstoke: Palgrave Macmillan. https://doi.org/10.1057/9780230302464

Moya, J. C. (2005). "Immigrants and Associations: a Global and Historical Perspective". Journal of Ethnic and Migration Studies. 31(5), 833-864. https://doi.org/10.1080/13691830500178147

PIDOP (2012). "What do psychological theories tell us about citizen participation?". In PIDOP Policy Briefing Paper 4. European Commission, European Research Area, Social Science and Humanities. [http://www.fahs.surrey.ac.uk/pidop/docu ments/Briefings/PIDOP\%20Policy\%20Briefing\%20Paper\%20No.\%204.pdf]

Pharr, S. J. and Putnam R.D. (2000). Disaffected democracies. What's troubling the trilateral countries? Princeton: Princeton University Press.

Portes, A.; Guarnizo, L.E. and Landolt, P. (1999). The study of transnationalism: pitfalls and promise of an emergent research field. Ethnic and Racial Studies 22: 217-237. https://doi.org/10.1080/014198799329468

Raffini, L. (2008). "Cittadini precari. I giovani italiani tra fuga nel privato e nuove forme d'impegno". In A. Pirni, G., Bettin Lattes and; S. Monti Bragadin, (eds.) Tra il palazzo e la strada. Soveria Mannelli: Rubbettino.

Recchi, E. (2015). Mobile Europe: The Theory and Practice of Free Movement in the EU. Basingtoke: Macmillan. https://doi.org/10.1057/9781137316028

Ryan, L.; Sales, R.; Tiki, M. and Siara, B. (2008). "Social Networks, Social Support and Social Capital: The Experience of Recent Polish Migrants in London". Sociology 42, 672-687. https://doi.org/10.1177/0038038508091622

Santacreu, O. (2008). "La participación social de los jóvenes españoles". OBETS. Revista de Ciencias Sociales 2, 25-34. https://doi.org/10.14198/OBETS2008.2.02

Schrover, M. and Vermeulen, F. (2005). "Immigrant Organizations". Journal of Ethnic and Migration Studies 31(5), 823-832. https://doi.org/10.1080/13691830500177792

Torcal, M. and Montero, J. R. (2006). Political Disaffection in Contemporary Democracies. Social Capital, Institutions and Politics. London-New York: Routledge.

Trenz, H.-J. and Eder, K. (2009). "The democratizing dynamics of a European Public Sphere. Towards a Theory of Democratic Functionalism". European Journal of Social Theory 7(1), 5-25. https://doi.org/10.1177/1368431004040016

Verba, S, Schlozman, K.L. and Brady, H.E. (1995). Voice and Equality: Civic Volunteerism in American Politics. Cambridge: Harvard University Press.

Verba, S. and Nie, N.H. (1972). Participation in America: Political democracy and social equality. New York: Harper and Row. 


\section{BREVES NOTAS BIOGRÁFICAS}

ANTONIO ALAMINOS is Professor of Mathematical Sociology at the University of Alicante. His research interests are the methods and techniques of comparative social research, socialization and acculturation processes and the dynamics of social and political change.

https://orcid.org/0000-0002-7294-9878

CLEMENTE PENALVA: PhD in Sociology, associate professor at the Departament of Sociology II (University of Alicante). His main research interests are social capital and social mobilisation, mutual support networks and networks for political action, and the economic dimension of social trust.

https://orcid.org/0000-0002-5408-388X

LUCA RAFFINI: PhD in Sociology and Political Sociology from the University of Florence. Fellow Researcher at the Department of Political Science, University of Genoa. Among his interest of research: participation and social movement, migration and mobility, youth condition.

https://orcid.org/0000-0002-0689-2316

OSCAR SANTACREU: PhD in Sociology from the University of Alicante, full professor of sociology at the Department of Sociology II and researcher at the Interuniversity Institute for Social Development and Peace (University of Alicante). He belongs to the European Observatory of Social Trends. Academic coordinator of the Degree in Sociology at the Faculty of Economic and Business Sciences of the University of Alicante. Research lines: migration and mobility, social participation, ethnocentrism, European integration, research methodology and methods and techniques for social innovation.

https://orcid.org/0000-0002-8903-8683

Recibido: 11-09-2018

Aceptado: 10-10-2018

\section{(c) (1) Licencia Creative Commons Reconocimiento (CC BY 4.0)}




\section{LEISURE SPORTS HABITS IN SPANISH ADULTS: GENDER AND SOCIAL DIFFERENCES HABITOS DEPORTIVOS DE OCIO EN ADULTOS ESPAÑOLES: GÉNERO Y DIFERENCIAS SOCIALES}

\author{
María Espada \\ Universidad Politécnica de \\ Madrid, Madrid. Spain. \\ maria.espada@upm.es \\ María Martín \\ Universidad Politécnica de \\ Madrid, Madrid. Spain \\ maria.martin@upm.es \\ Víctor Jiménez \\ Universidad Camilo José Cela, \\ Madrid. Spain \\ vjdiaz-benito@ucjc.edu
}

\author{
David Moscoso \\ Universidad Pablo de Olavide, \\ Sevilla. Spain \\ dmoscoso@upo.es
}

Emilio Jiménez-Beatty

Universidad de Alcalá.Spain emilio.beatty@uah.es

Antonio Rivero

Universidad Politécnica de Madrid, Madrid. Spain antonio.rivero@upm.es

\section{Cómo citar / citation}

Espada, M., Martín, M., Jiménez, V., Moscoso, D., Jiménez-Beatty, E. y Rivero, A. (2018) "Leisure sports habits in Spanish adults: gender and social differences". OBETS. Revista de Ciencias Sociales, 13(2): 495-513.

doi: 10.14198/OBETS2018.13.2.02

\section{Abstract}

The aim of this study was to analyse sports habits in Spanish adults according to the temporal aspects of the activities, gender and social class. The research followed a cross-sectional quantitative methodology. The sample was made up of 3.463 people, 1.732 men ( $46.6 \pm 9.7$ years) and 1.731 women $(44.5 \pm 9.6$ years). Twostep cluster and classification tree (Exhaustive-Chi-squared Automa- 
tic Interaction Detection) multivariate models were used to identify the best predictor variables on the temporal aspects of the sports activities. The results show that women and older people have fewer sports habits.

Keywords: physical activity and sport; age; gender; educational level and social class.

\section{Resumen}

El objetivo principal de este estudio fue analizar los hábitos deportivos de los adultos españoles según los aspectos temporales de las actividades, el género y la clase social. La investigación siguió una metodología cuantitativa y transversal. La muestra estuvo formada por 3,463 personas, 1,732 hombres (46,6 $\pm 9,7$ años) y 1,731 mujeres (44,5 $\pm 9,6$ años). Se ha realizado un método de análisis multivariante (análisis cluster) a través de la técnica del árbol de decisión (CHAID exhaustivo) para identificar las mejores variables predictivas en los aspectos temporales de las actividades deportivas. Los resultados muestran que las mujeres y las personas mayores son los grupos que tienen menos hábitos deportivos.

Palabras clave: Actividad Física y Deporte; edad; género; nivel educativo y clase social.

\section{INTRODUCTION}

The increase in the adult population in the last few decades, together with the effect of the present economic crisis, and the decrease in income and consumption (Laparra et al., 2012), suggest the advisability of carrying out research to acquire more detailed knowledge of the repercussions that these changes may have on the habits and demand for sports services in the Spanish adult population. With regard to these changes, one of the tendencies underlined by García Ferrando and Llopis (2011) in their survey of sports habits in Spain was the increase in autonomous practice (75\%) and the decrease in organised practice in both sexes and different age groups. This trend, which represents an important change in the Spanish market for sports services, was already visible in 1990 but has become more accentuated in the last few years.

From another perspective, it is worth mentioning how important it is for the large population of adults to incorporate regular sports practice into their lifestyles. This would have tremendous repercussions on their health and quality of life, as well as current and future health spending (Stearns et al., 2000), especially with regard to women as they have a longer life expectancy and greater prevalence of disease. 
There is a great deal of scientific evidence that physically active people have better levels of physical health and lower rates of chronic illnesses (USDHHS, 2008). Similarly, many studies have shown the benefits that sport brings to those that practise it, not only at the physical level but also at the psychological, affective and social level (Strawbridge et al., 2002).

Recently in Spain it has emerged that people who practise sport report better health and improved well being and also see their lives in a more positive light; that sports practice improves this perception and that, together with age, work and family situation, sport is one of the four elements that most influence the perception of quality of life in the adult population (Moscoso et al., 2008).

All the international recommendations for health (World Health Organisation, Public Health Agency of Canada, The U.S. Department of Health and Human Services, U.K The National Health Service, among others), propose including measures and programmes of physical activities in public health polices in all countries to reduce the huge problems associated with sedentary behaviour. These measures and programmes are recommended especially for women and others social groups with more prevalence of a sedentary lifestyle.

If the results of the last Eurobarometer on sport in 2014 (European Commission, 2014) are analysed it can be seen that the weekly rate of sports practice (without including walking or dancing) in the adult European population between 40 and 54 years is $40 \%$ in men and 36\% in women. This study also specifies that the rate of weekly practice in Spain has increased in the last few years to around 36\% nearing the European average of $41 \%$.

The successive sociological studies on sports habits in Spain carried out by the Centre for Sociological Research in 2011, directed by Manuel García Ferrando and financed by the High Council of Sport, have also highlighted the fact that in Spain, in the last few decades, the number of people practising a sport regularly and sporadically (including dancing but not walking) has increased to $43 \%$, in the 35 to 44 age group has increased to $44 \%$ and $30 \%$ in the 44 to 55 age group. This reference source in Spain has also shown the evolution of the imbalances in sports practice between men and women in general (young people, adults and the elderly); imbalances which have been decreasing but which are still important: $31 \%$ of women practising versus $49.1 \%$ of men. Some of the factors that influence the lower level of practice of physical activities in women are more family and labour responsibilities, resulting in less free time (Martínez del Castillo et al., 2005), so it is interesting to ascertain the temporal aspects of sports habits in women to design suitable public health polices. 
Given the scarcity of studies on the sports practice of adult men and women carried out after the start of the current economic crisis, and with the understanding that knowledge of their demands is one of the requirements for public and private sports organisations to be able to suitably adapt their provision of services, the objectives of the present study with respect to women and men between 30 and 64 years of age, were:

- To discover the sports habits of Spanish adults in relation to different temporal aspects and their distribution among the different social groups.

- To determine if there existed relations between the sports habits analysed and the different social groups, also studying possible gender differences.

\section{METHODOLOGY}

\section{Participants}

The size of the final sample was of 3,463 adults, 1,732 men (mean age 46.6 years \pm 9.7 ) and 1,731 women (mean age 44.5 years \pm 9.6 ).

Table I. Sociodemographic characteristics by gender

\begin{tabular}{|c|c|c|c|}
\hline & & Man & Woman \\
\hline \multirow[t]{4}{*}{ Age } & $30-39$ & $34,6 \%$ & $32,5 \%$ \\
\hline & $40-49$ & $34,1 \%$ & $32,5 \%$ \\
\hline & $50-59$ & $22 \%$ & $25 \%$ \\
\hline & $60-64$ & $9,4 \%$ & $10,2 \%$ \\
\hline \multirow[t]{3}{*}{$\begin{array}{c}\text { Level of completed } \\
\text { education }\end{array}$} & $\begin{array}{l}\text { Less than } \\
\text { primary }\end{array}$ & $7,8 \%$ & $10,1 \%$ \\
\hline & $\begin{array}{c}\text { Non- } \\
\text { university }\end{array}$ & $64,4 \%$ & $62,6 \%$ \\
\hline & University & $27.8 \%$ & $27,2 \%$ \\
\hline \multirow[t]{3}{*}{ Social class } & Upper & $4,4 \%$ & $5 \%$ \\
\hline & Middle & $60 \%$ & $60,1 \%$ \\
\hline & Lower & $35 \%$ & $34,9 \%$ \\
\hline
\end{tabular}

Source: Prepared by the authors 
Design and procedure: The methodology consisted of carrying out structured interviews with a statistically representative sample of the women and men between 30 and 64 resident in Spain (47,265,321 people (100\%), 23,966,965 women (50\%) and 23,298.356 men (50\%) according to the National Institute of Statistics Municipal Census for 2012). Given that this population is infinite or very numerous, working with a confidence interval of $95.5 \%$, and assuming in the populational variance the worst case of $\mathrm{p}$ equalling $\mathrm{q}$, the sampling margin of error was $\pm 1.7 \%$. The sampling method chosen was multistage probability (Bryman, 2004). In Stage one, the sampling units were municipalities; that is, there was a random selection of municipalities in Spain, where the interviews with the adults were to be carried out using the questionnaire. Interviews were conducted in proportion to the number of adults residing in the municipalities in Spain, according to their population (less than 10,000 inhabitants; between 10,000 and 50,000; between 50,000 and 100,000; and more than 100.000).

In Stage two, the sampling units were the 348 streets at the start of each interviewer's route (there were 348 routes) in each of the boroughs selected in the previous stage. These streets were randomly selected. Each interviewer's route consisted of ten interviews; that is, the questionnaire was to be administered to ten adults, five women and five men (selection was made proportional to the gender distribution of the population of adults residing in Spain).

In Stage three, the sampling units were the adults $(\mathrm{N}=3,480)$ that should be selected for interviewing in their homes, using the research questionnaire. Only one adult was interviewed in each home; the only selection criterion was that the person had to be between 30 and 64 years, and they could be either male or female, depending on the interviews pending in each route. Each participant was informed about the characteristics of the research, the anonymity of their answers and their protection according to the Data Protection Law. When the participants gave their verbal consent to participate in the study, we proceeded to apply the questionnaire. Finally, a total of 3,463 adults gave their consent to participate in the research.

The Ethics Committee from the research group on psychosocial aspects in physical activity and sport in the Faculty of Physical Activity and Sport Sciences, Polytechnic University of Madrid, Spain, approved the study protocol.

The field work was carried out during the months of October to December 2012, January and February 2013 and October to December 2013. The interviewers applied the written questionnaire in personal face-to-face interviews, in the adult's normal home. Since the sample is totally random and probabilistic, the results could be generalised to all Spanish adults. 
Instrument: The instrument used to collect the data and which needed to fulfil the objectives of the study, was drawn up using the "Questionnaire on physical activity and sport in women: habits, demand and barriers" [Cuestionario de actividad física y deporte en mujeres: hábitos demandas y barreras] (Martínez del Castillo et al., 2005) designed to measure the demand for physical activity in adult women and other related variables, which has already been applied and validated in several studies.

Statistical analyses: Firstly, the analyses performed were: descriptive (a univariate analysis with frequency distribution tables and a bivariate analysis with relative frequency tables) and inferential, using Pearson's chi-squared test. The significance level was set at 0.05 .

Secondly, a two-step clustering procedure, using indexes derived from principal component analysis, was used to disclose temporal aspects of sports habits within the time chosen for weekly practice, time of the day chosen for practising sport and duration of the sports session. Moreover, a classification tree analysis was used to determine temporal aspects of sports habits according to social differences. This technique allows splitting the sample into different subgroups (nodes) based on the impact of predictions (i.e. gender, age, social class, level of completed education) on temporal aspects of sports habits. Furthermore, this analysis provides visual information from the impact of each independent variable in a hierarchical tree model (Camp \& Slattery, 2002; Schnell, Mayer, Diehl, Zipfel, \& Thiel, 2014). The algorithm used was the exhaustive CHAID (Chi-square automatic interaction detection), appropriate for nominal dependent and independent variables. The chi-square test identifies the relationships between independent variables by completing three steps on each node of the root (merging, splitting and stopping) to find the analysts that exert the most influence on the dependent variable. The exhaustive CHAID examines all possible splits for each predictor and the merging step increases the search procedure to merge any similar pair until only one single pair remains (Schnell et al., 2014).

The following statistical specifications were considered: (i) significance level was set to $\mathrm{P}<0.05$; (ii) Pearson's Chi-square was used to detect the relationships between independent variables; (iii) the maximum number of interactions was 100; (iv) the minimum change in expected cell frequencies was 0.001 ; (v) the significant values adjustment was done using the Bonferroni method; and (vi) the tree had a maximum of 5 levels in order to reduce the misclassification risk. Finally, the risk of misclassification was calculated as a measure of the reliability of the model (Schnell et al., 2014). Both statistical 
analyses were performed using IBM SPSS statistics for Windows, version 20.0 (Armonk, NY: IBM. Corp.)

\section{Results}

\section{Unadjusted analyses}

Table II below shows that people between 30 and 39 years of age mainly practise sport during the week independently of gender, while for the rest of the age groups women mainly practise on weekdays while men practise on weekdays and at weekends. There was a low but statistically significant relation between age and time chosen for weekly practice and the age ranges 30 to 39 [ $2(4)=58.346 ; \mathrm{p}<.00 ;=.24], 40$ to $49[2(3)=40.285 ;=.20], 50$ to 59 [ $2(3)=$ $42.128 ;=.25$ ] and 60 to 64 [ $2(3)=11.983 ;=.21]$.

With regard to formal education, the people with a lower level of completed education practise sport mainly on weekdays and at weekends irrespective of gender. Women with a university and non-university education mainly practise on weekdays and men practise on weekdays and at weekends, although in the latter the percentages obtained are very similar to those for practise on weekdays. A moderate and statistically significant relation has been obtained between time chosen for weekly practice and people with less than primary education [ $2(3)=14.113 ;=.26$ ] and a statistically significant but low relation with people with a non-university [ $2(3)=98,302 ;=.23$ ], and university [ $2(3)=35.532 ;=.20$ ] education.

Finally, it seems that men belonging to the upper social class state that they practise sport mainly on weekdays and at weekends, with similar percentages and women mainly during the week. Middle class people practise mainly on weekdays irrespective of gender. For their part the men from the lower class practise sport on weekdays and at weekends and the women on weekdays. There is no statistically significant relation between people belonging to the upper social class and time chosen for weekly practice [ $2(3)=4.194 ;=.17]$. A statistically significant but low relation was observed between with people from the middle class [ $2(3)=81.433 ;=.22$ ] and a moderate and statistically significant relation with people from the lower class [ $2(4)=55.639 ;=.25]$.

Table III shows that people of between 30 and 49 years of age mainly practise sport in the afternoon and evening irrespective of gender, as do women between 50 and 59, while men of the same age state that the morning is the time when they mostly practise sport. People between 60 and 64 chose the morning as the time when they mostly do sport although with a similar percentage to 
Table II. Moment chosen for weekly practice as a function of age, level of completed education and social class

\begin{tabular}{|c|c|c|c|c|c|c|}
\hline & & & $\begin{array}{c}\text { Weekdays } \\
\%\end{array}$ & $\begin{array}{c}\text { Weekends } \\
\%\end{array}$ & $\begin{array}{c}\text { Weekdays } \\
\text { and } \\
\text { weekends } \\
\%\end{array}$ & $\begin{array}{c}\text { When I can } \\
\%\end{array}$ \\
\hline \multirow[t]{8}{*}{ Age } & \multirow[t]{2}{*}{$30-39$} & & 37.5 & 19.1 & 33.4 & 9.8 \\
\hline & & Woman & 59.1 & 7.0 & 25.0 & 8.9 \\
\hline & \multirow[t]{2}{*}{$40-49$} & Man & 35.9 & 18.2 & 37.1 & 8.8 \\
\hline & & Woman & 53.5 & 7.5 & 32.5 & 6.4 \\
\hline & \multirow[t]{2}{*}{$50-59$} & & 29.1 & 17.9 & 44.3 & 8.8 \\
\hline & & Woman & 48.2 & 5.6 & 42.3 & 3.8 \\
\hline & \multirow[t]{2}{*}{$60-64$} & & 30.2 & 6.9 & 55.2 & 7.8 \\
\hline & & Woman & 50.7 & 2.8 & 40.8 & 5.6 \\
\hline \multirow{6}{*}{$\begin{array}{l}\text { Level of } \\
\text { completed } \\
\text { education }\end{array}$} & \multirow[t]{2}{*}{$\begin{array}{l}\text { Less than } \\
\text { primary }\end{array}$} & Man & 25.3 & 10.3 & 49.4 & 14.9 \\
\hline & & Woman & 43.5 & 5.2 & 47.8 & 3.5 \\
\hline & \multirow[t]{2}{*}{$\begin{array}{c}\text { Non- } \\
\text { university }\end{array}$} & & 34.4 & 18.8 & 37.8 & 8.9 \\
\hline & & Woman & 54.5 & 6.6 & 32.9 & 6.1 \\
\hline & \multirow[t]{2}{*}{ University } & Man & 37.2 & 16.2 & 38.4 & 8.2 \\
\hline & & Woman & 54.5 & 6.5 & 30.6 & 8.4 \\
\hline \multirow[t]{6}{*}{$\begin{array}{c}\text { Social } \\
\text { class }\end{array}$} & \multirow[t]{2}{*}{ Upper } & Man & 40.6 & 15.6 & 40.6 & 3.1 \\
\hline & & Woman & 45.9 & 6.8 & 39.2 & 8.1 \\
\hline & \multirow[t]{2}{*}{ Middle } & Man & 36.9 & 18.6 & 35.9 & 8.6 \\
\hline & & Woman & 55.0 & 6.6 & 31.3 & 7.2 \\
\hline & \multirow[t]{2}{*}{ Lower } & Man & 31.0 & 15.8 & 43.4 & 9.6 \\
\hline & & Woman & 52.9 & 6.0 & 35.8 & 5.3 \\
\hline
\end{tabular}

Source: Prepared by the authors 
those practising in the afternoon and evening. Furthermore, there is a low relation but statistically significant with participants of between 40 to 49 years of age [ $2(4)=12.606 ;=.11]$ and 50 to 59 [ $2(4)=18.150 ;=.16]$. However, there was no statistically significant relation with participants of 40 to 49 [ $2(4)=$ $12.606 ;=.11$ ], 50 to 59 [ $2(4)=18.150 ;=.16], 30$ to 39 [ $2(5)=7.392 ;=.08$ ], 60 to 64 [ $2(4)=4.693 ;=.13]$.

The moment of the day when sport is mostly practiced is in the afternoon and evening irrespective of gender and level of completed education. There is also a moderate and statistically significant relation between time of the day chosen for practising sport and the people with a lower level of completed education [ $2(4)=17.150 ;=.29$ ], and a statistically significant but low relation with those who have a non-university [ $2(4)=14.808 ;=.09$ ], and those who have a university education [ $2(4)=10.631 ;=.11]$.

With regard to social class, it can be seen that men from the upper class mainly practise sport in the mornings and women in the afternoon and evening. Middle class people mainly practise sport in the afternoon and evening. For their part men from the lower class carry out their sporting activities mainly in the morning and the women in the afternoon and evening, although in both cases the percentages are very similar. However, there was no statistically significant relation between time of the day chosen for practising sport and participants from the upper class [ $2(4)=2.486 ;=.13$ ]; although, there was a low and statistically significant relation with people from the middle class [ $2(4)=$ $15.610 ;=.09]$, and a moderate and statistically significant relation with the people from the lower class [ $2(4)=19.479 ;=.10]$.

Table IV shows that a greater percentage of women, irrespective of age, practise in one hour sessions. In contrast men practise sport in sessions lasting between one and two hours, with the exception of men from 60 to 64 who mostly state that they practise for one hour. A moderate and statistically significant relation has been obtained between the duration of the sports session and all age ranges 30 to 39 [ $2(4)=78.394 ;=.28$ ], 40 to 49 [ $2(4)=94.518 ;=$ .31 ], 50 to 59 [ $2(3)=53.356 ;=.29], 60$ to 64 [ $2(3)=18.295 ;=.26]$.

If we consider level of completed education, men mostly practise sport in sessions of between one and two hours, except those who have a university education, who mostly practise in one hour sessions. With regard to the women, irrespective of their level of completed education, they mostly practise in one-hour sessions. Here it can be seen that women with a lower level of completed education are less likely to practise for between one and two-hours and more than two hours. A moderate and statistically significant relation has been obtained between the duration of the sports session and people with less 
Table III. Time of the day chosen for practising sport as a function of age, level of completed education and social class

\begin{tabular}{|c|c|c|c|c|c|c|c|}
\hline & & & $\begin{array}{c}\text { Morning } \\
\%\end{array}$ & $\begin{array}{c}\text { Midday } \\
\%\end{array}$ & $\begin{array}{c}\text { Afternoon and } \\
\text { evening } \\
\%\end{array}$ & $\begin{array}{c}\text { Night } \\
\%\end{array}$ & $\begin{array}{c}\text { When I } \\
\text { can } \\
\%\end{array}$ \\
\hline \multirow[t]{8}{*}{ Age } & $30-39$ & & 24.4 & 3.8 & 39.8 & 7.3 & 24.6 \\
\hline & & Woman & 29.8 & 3.3 & 41.3 & 6.5 & 19.1 \\
\hline & $40-49$ & & 30.1 & 3.1 & 32.6 & 6.8 & 27.5 \\
\hline & & Woman & 31.2 & 3.8 & 40.7 & 5.3 & 19.0 \\
\hline & $50-59$ & & 37.2 & 2.0 & 28.4 & 5.1 & 27.4 \\
\hline & & Woman & 36.3 & 3.5 & 40.4 & 3.8 & 15.9 \\
\hline & $60-64$ & Man & 44.8 & 3.4 & 26.7 & 2.6 & 22.4 \\
\hline & & Woman & 38.0 & 7.0 & 35.2 & 1.4 & 18.3 \\
\hline \multirow{6}{*}{$\begin{array}{l}\text { Level of } \\
\text { completed } \\
\text { education }\end{array}$} & Less than & & 29.9 & 0.0 & 33.3 & 4.6 & 32.2 \\
\hline & & Woman & 38.3 & 6.1 & 40.9 & 2.6 & 12.2 \\
\hline & $\begin{array}{c}\text { Non- } \\
\text { university }\end{array}$ & & 32.4 & 2.6 & 32.7 & 6.7 & 25.6 \\
\hline & & Woman & 34.8 & 3.8 & 37.0 & 5.0 & 19.3 \\
\hline & University & Man & 26.9 & 5.0 & 37.2 & 5.9 & 24.9 \\
\hline & & Woman & 26.8 & 3.3 & 46.4 & 5.5 & 17.9 \\
\hline \multirow[t]{6}{*}{$\begin{array}{l}\text { Social } \\
\text { class }\end{array}$} & Upper & Man & 39.1 & 4.7 & 29.7 & 4.7 & 21.9 \\
\hline & & Woman & 31.1 & 4.1 & 41.9 & 2.7 & 20.3 \\
\hline & Middle & Man & 28.8 & 3.6 & 35.3 & 6.7 & 25.6 \\
\hline & & Woman & 31.1 & 3.8 & 41.2 & 5.5 & 18.4 \\
\hline & Lower & Man & 33.4 & 1.3 & 32.7 & 5.1 & 27.2 \\
\hline & & Woman & 34.4 & 4.2 & 39.3 & 4.2 & 17.9 \\
\hline
\end{tabular}

Source: Prepared by the authors 
Table IV. Duration of the sports session as a function of age, level of completed education and social class

\begin{tabular}{|c|c|c|c|c|c|c|}
\hline & & & $\begin{array}{c}\text { Less than } \\
\text { an- hour } \\
\%\end{array}$ & $\begin{array}{c}\text { An-hour } \\
\%\end{array}$ & $\begin{array}{c}\text { Between } \\
\text { one and } \\
\text { two- hours } \\
\%\end{array}$ & $\begin{array}{c}\text { More than } \\
\text { two-hours } \\
\%\end{array}$ \\
\hline \multirow[t]{8}{*}{ Age } & \multirow[t]{2}{*}{$30-39$} & Man & 8.4 & 30.0 & 40.2 & 21.0 \\
\hline & & Woman & 10.4 & 52.2 & 31.5 & 5.9 \\
\hline & \multirow[t]{2}{*}{$40-49$} & Man & 10.5 & 29.0 & 38.6 & 22.0 \\
\hline & & Woman & 9.1 & 57.5 & 26.5 & 6.6 \\
\hline & \multirow[t]{2}{*}{$50-59$} & Man & 7.1 & 34.8 & 35.5 & 22.6 \\
\hline & & Woman & 12.1 & 54.0 & 28.3 & 5.6 \\
\hline & \multirow[t]{2}{*}{$60-64$} & Man & 7.8 & 37.9 & 34.5 & 19.8 \\
\hline & & Woman & 9.9 & 59.9 & 23.9 & 6.3 \\
\hline \multirow{6}{*}{$\begin{array}{l}\text { Level of } \\
\text { completed } \\
\text { education }\end{array}$} & \multirow[t]{2}{*}{$\begin{array}{l}\text { Less than } \\
\text { primary }\end{array}$} & & 6.9 & 25.3 & 37.9 & 29.9 \\
\hline & & Woman & 9.6 & 60.0 & 26.1 & 4.3 \\
\hline & \multirow[t]{2}{*}{ Non-university } & & 7.3 & 28.3 & 41.0 & 23.3 \\
\hline & & Woman & 9.7 & 55.9 & 28.0 & 6.2 \\
\hline & \multirow[t]{2}{*}{ University } & & 12.6 & 38.4 & 32.6 & 16.4 \\
\hline & & Woman & 12.0 & 52.2 & 29.4 & 6.5 \\
\hline \multirow[t]{6}{*}{$\begin{array}{l}\text { Social } \\
\text { class }\end{array}$} & \multirow[t]{2}{*}{ Upper } & & 21.9 & 32.8 & 26.6 & 18.8 \\
\hline & & Woman & 12.2 & 58.1 & 21.6 & 8.1 \\
\hline & \multirow[t]{2}{*}{ Middle } & Man & 7.7 & 32.9 & 38.8 & 20.5 \\
\hline & & Woman & 10.1 & 55.0 & 28.5 & 6.3 \\
\hline & \multirow[t]{2}{*}{ Lower } & Man & 9.8 & 28.1 & 38.1 & 23.8 \\
\hline & & Woman & 11.0 & 55.0 & 29.4 & 4.6 \\
\hline
\end{tabular}

Source: Prepared by the authors 
than primary education $2(3)=36.943 ;=.42$ ] and with people with a non-university education [ $2(4)=189.197 ;=.32$ ], and a statistically significant but low relation with the people with a university education [ $2(3)=28.221 ;=.18]$.

With regard to social class, it can be seen that men from the upper class indicate that the duration of the sports sessions is mainly one hour while the men from the middle and lower classes mostly carry out sports activities in sessions of between one and two hours. Women irrespective of their social class practise sport in one hour sessions. Furthermore, there is a moderate and statistically significant relation between the duration of the sports session and participants from the upper class [ $2(3)=10.008 ;=.27]$, middle class $[2(4)=$ $125.048 ;=.27$ ], lower class [ $2(4)=104.243 ;=.34]$.

\section{Multivariable}

The analysis starts with the root node. All the predictor variables are tested for their significance in splitting the data set (Camp \& Slattery, 2002). In Figure 1, the predictor "Gender" (a dichotomous variable) is the most significant and the tree splits using this variable, producing two child nodes, one for "Gender= man"and one for"Gender=woman. The p- value, chi-squared value, and degrees of freedom are also illustrated. At level 1 the "Gender=man" and "Gender= Woman" node splits further, and it divides based on "Age" which is an ordinal variable with two levels $(<=43$ and $>43)$. The final tree has two levels and six terminal nodes.

The various categories that the target variable can take are illustrated within each node; there are three different categories according to time chosen for weekly practice; time of the day and duration of the sports session in the statistical model. The first category includes practice weekends and weekdays, between one- and two-hour sessions and at the moment of the day when they can. The second category includes practice weekdays, more than two hours and in the morning. The third category includes practice weekdays, an hour in the afternoon and evening.

The results showed only two significant inducing factors on temporal aspects of sports habits (two-stage tree). The following factors led to 6 nodes of contrasting groups, mainly established by gender (level 1) and age (level 2). Figure 1 shows the categories for the predictor variable and also the 6 nodes defined by the tree analysis classification.

Level 1 (root node) is split by gender. Men mostly practise sport weekends and weekdays, between one and two hours sessions and at the moment of the day when they can (node 1: $46.6 \%$ category $1 ; n=668$ ) while women practise weekdays, an hour in the afternoon and evening (node 2: $46.8 \%$ category 3; $n=651$ ). 
Figure 1. Classification tree analysis (Source: Prepared by the authors)

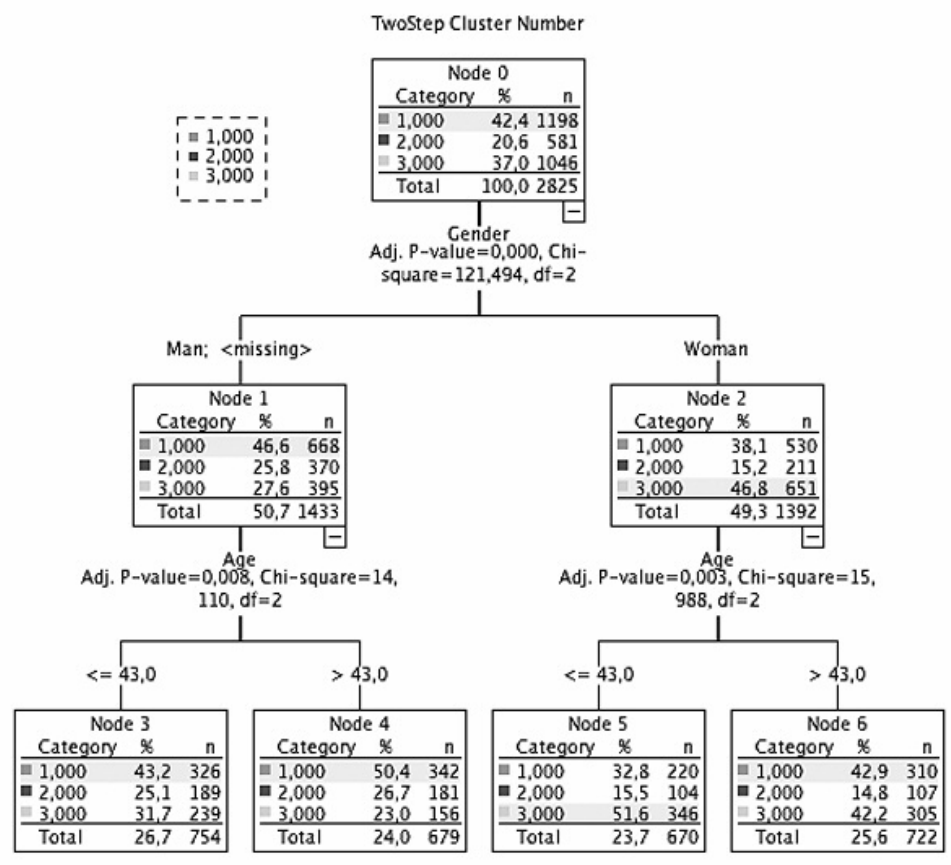

At level 2, there were smaller differences in men than in women. The majority of the men, irrespective of their age, are included in the first category, practise weekends and weekdays, between one and two hour sessions and at the moment of the day when they can (node $3: 43.2 \%$ category $1 ; n=326$; node $4: 50,4 \%$ category $1 ; n=342$ ). Women under 43 years old are included in the third category, practise weekdays, an hour in the afternoon and evening (node $5: 51.6 \%$ category $3 ; \mathrm{n}=356$ ) while women who are more than 43 (node 6: $42.9 \%$ category $1 ; n=310$ ) are included in the first category, practise weekends and weekdays, between one and two hour sessions and at the moment of the day when they can. This classification tree model enabled explaining 46.9\% of total variance.

\section{DISCUSSION}

With regard to duration in all social groups men carry out longer sessions than women. In this line of research different studies show that men have a greater level of sports habits than women (Kaplan et al., 2001; Pitsavos et al., 2005; Aoyagi et al., 2009; European Commission, 2014; Maddah et al., 2014). 
In both genders it can be seen that with advancing age the total number of hours devoted to weekly sport diminishes, coinciding with the results obtained by different authors (Nowak, 2011; Maddah et al., 2014). ahin et al. (2014) in a study carried out with adult women who practised sport, found that the 40-49 age group was the one that presented the highest level of sports habits. These authors indicate that the majority of women practise sport during one hour a week, coinciding with the results of the present study. In contrast, Nowak (2011) found that the great majority of adult women practise sport for between 1 and 2 hours (36.9\%) or more (41.7\%).

The present study revealed that men with a lower level of completed education and lower social class are those that practise the most hours of sport per week, as they scored higher percentages of practice in the sum of the variables "between one and two hours" and "more than two hours".

Adult women revealed that as their level of completed education rises the number of hours spent practising sport per week also rises (between one or two or more hours), an aspect which is not seen in the men. Maddah et al. (2014) reported identical results on this topic in a study carried out in Iran. Similarly, in research by other authors it appears that women with a higher level of completed education have greater sports habits than those with a lower level (Pitsavos et al., 2005; Kruger, Carlson and Buchner, 2007; Nowak, 2011; Odunaiya, Aderibigbe and Oguntibeju, 2011). Equally in the study by ahin et al. (2014) it was revealed that the majority of women who practise sport have a level of completed education higher than primary studies, which may be due to the fact that adult women with a higher level of completed education have more information and are more aware about the benefits of practising sport. However, it has been observed that in men this is not the case. In this line of thought, Odunaiya et al. (2011) explain that in spite of the fact that most people $(73.65 \%)$ are fully aware of the benefits of practising sport for their health, their sports habits are insufficient. However, different authors maintain that individual motivation together with knowledge can play an important role in improving sports habits (Bouchard and Rankinen, 2001; Norman et al., 2007; Odunaiya, et al., 2011).

With regard to social class, it seems that there is not a clear association between this variable and the duration of the practice session in either of the gender groups. Similarly, Pitsavos et al. (2005) also found that this variable had no relation with sports habits in a study carried out in Greece.

The time of day when most adults practise sport is in the afternoon and evening, irrespective of gender and level of completed education, coinciding with the results obtained in the survey of leisure time carried out by the Natio- 
nal Institute of Statistics (Del Barrio, 2007). In this regard, account has to be taken of the fact that the time of day when the majority of adults have the possibility to practise is from 17:30 to 20:30 (Del Barrio, 2007). However, it can be seen that there are certain social groups who mostly practise in the morning: men from the upper class, men of over 50 and women of over 60. Moreover, it appears that in both genders the middle class and people with a higher level of completed education indicate higher percentages of practice in the afternoon. Furthermore, a higher percentage of practice in the morning is recorded with advancing age, both in the men and in the women, coinciding with the results obtained by Martínez del Castillo et al. (2009). Similarly, this result coincides with that obtained by Cohen-Mansfield, Marx, Biddison and Guralnik (2004) in a study of older adults, which indicated that this population group prefers to practise sport before midday. The present study revealed that most adult women of between 50 and 59 years practise sport in the afternoon and evening.

With regard to the moment at which sport is practised, the present study found that, in general, women of all ages are less likely to do sport on weekdays, although the highest percentages obtained in all cases is for "weekdays and weekends". It can also be stated that with advancing age adults of both genders score a lower percentage on the items of doing sport at the weekend or when they can This is possibly due to the greater amount of time that adults have on weekdays for leisure activities as they grow older. Similarly, Martínez del Castillo and Jiménez-Beatty (2002) found that the older adults preferred to practise on weekdays. The level of completed education did not appear to be a determinant variable in either gender for the selection of the day of the week for practising, although it is worth mentioning that a high percentage of men with a lower level of completed education state that they practise when they can in relation to the rest of the groups.

Finally, it can be seen that women state that they practise sport on weekdays. The results from the classification tree analysis identified gender as the most important predictor for determining temporal aspects of sports habits. This aspect may be due to the difference in family responsibilities (Odunaiya et al., 2011), because women may have to continue to play their traditional role of taking care of the housework, much of which is done during the weekend, a time when adults, in general, have fewer professional obligations.

Another aspect that could explain the difference in temporary organization of sport practice is the type of activity they practice, as women are involved in collective classes (body-mind, activities with music and maintenance gymnastics) and demand swimming, whilst men practice and demand more cycling, 
running, outdoor sports, football, bodybuilding and fitness rooms. These last ones are more autonomous activities that are not conditioned by the offer schedule of the activities in sports facilities, what could explain the bigger temporary flexibility in the sport practice by men (Martín and Martín, 2014).

Regarding the limitations of the study, on the one hand, the field work was carried out during the months of October to December 2012, January and February 2013 and October to December 2013 so the potential cross-sectional design may limit assessment of the temporal and thus potential causal relation of the variables. Therefore, it would be interesting to continue working in this field in Spain in the future to be able to verify that the variables studied are stable over time. On the other hand, the sample is of Spanish adults so the results cannot be generalised to other countries. It would be interesting to study these variables in adults in other countries, with random and probabilistic sampling, to help them to better adjust their public health and physical activities polices.

\section{CONCLUSIONS}

Within the most relevant conclusions of the present study it is remarkable that it is the gender variable the one that conditions to the greatest extent the temporary differences in sports habits. Men mostly practice sport during weekends and weekdays, for one to two hours sessions, at the moment of the day when they can, in the same way as women aged over 43 . However, women under 43 years of age practice sport during weekdays, for an hour in the afternoon and the evening.

This difference may be due on one hand to the difference in familiar responsibilities, and on the other hand to the difference in the activities practiced, as men tend to prefer more autonomous and outdoor activities, whilst women prefer guided activities in sports facilities that are submitted to a determined schedule.

These results could be used by the different entities responsible for sports organisation to adapt their programmes to the temporal sports leisure habits of the adult population, bearing in mind the existing socio-demographic differences in some of the variables studied. This could improve the effectiveness of public health policies to reduce sedentary lifestyle in more sedentary social groups, and among them adult women.

\section{REFERENCES}

Aoyagi et al. (2009). Habitual Physical Activity and Physical Fitness in Older Japanese Adults: The Nakanojo Study. Gerontology, 55, 523-531. 
Bouchard, C. \& Rankinen, T. (2001). Individual differences in response to regular physical activity. Medicine and Science in Sports and Exercise, 33, S446-S451.

Bryman, A. (2004). Social research methods. New York: Oxford University Press.

Camp, N., \& Slattery, M. (2002). Classification tree analysis: a statistical tool to investigate risk factor interactions with an example for colon cancer (United States). Cancer Causes \& Control, 13, 813-823. http://dx.doi.org/10.1023/A: 1020611416907.

Cohen-Mansfield et al. (2004). Socio-environmental exercise preferences among older adults. Preventive Medicine, 38, 804-811.

Del Barrio, E. (2007). Uso del tiempo entre las personas [The use of people's time]. Madrid: IMSERSO. Ministerio de Trabajo y Asuntos Sociales.

European Commission. (2014). Special Eurobarometer 412. Sport and physical activity. Bruselas: European Commission.

García-Ferrando, M. \& Llopis, R. (2011). Ideal democrático y bienestar personal, Encuesta sobre los hábitos deportivos en España 2010 [Democratic ideal and personal well being, Survey on sports habits in Spain 2010]. Madrid: Centro de Investigaciones Sociológicas-Consejo Superior de Deportes.

Instituto Nacional de Estadística.(2012). INEbase. Padrón Municipal. Explotación a 1 de enero de 2012. Instituto Nacional de Estadística [Municipal Census on $1^{\text {st }}$ January 2012.]. http://www.ine.es. (accessed April 15, 2013).

Kaplan et al. (2001). Demographic and Psychosocial Correlates of Physical Activity in Late Life. American Journal of Preventive Medicine, 21(4), 306-312.

Kruger, J., Carlson, S.A., \& Buchner, D. (2007). How active are older Americans? Preventing Chronic Disease, 4(3), 1-12.

Laparra et al. (2012). Crisis y fractura social en Europa. Causas y efectos en España. [Crisis and the social divide in Europe. Causes and effects in Spain] Colección Estudios Sociales $n^{\circ}$ 35. Barcelona: Fundación La Caixa.

Maddah et al. (2014). Prevalence of Regular Exercise among Iranian Adults: A Study in Northern Iran. Journal of Physical Activity and Health, 11,810-813.

Martín, M. \& Fierro, S. (Coords.). (2014). Necesidades, barreras e innovaciones en la oferta deportiva a las mujeres adultas en España [Needs, barriers and innovations in the offer sports for adult women in Spain]. Paper presented at Jornadas Nacionales Mujer y Deporte I+D+i. Madrid. Facultad de Ciencias de la Actividad Física y del Deporte. Universidad Politécnica de Madrid.

Martínez del Castillo, J. \& Jiménez-Beatty, J.E. (2002). Planificación de servicios de actividad física para las personas mayores [Planning physical activity services for older adults]. Paper presented at ler Congreso Internacional de actividad física y deportiva para personas mayores. Málaga: Servicio de Juventud y Deportes de la Diputación de Málaga.

Martínez del Castillo et al. (2009). The habits of physical activity of the older women in Spain. International Journal of Sport Science, 14, 81-93.

Martínez del Castillo et al. (2005). La actividad física y deportiva de las mujeres en el municipio de Madrid. [Physical and sports activities in women from the Madrid 
municipality] Madrid: Dirección General de Igualdad de Oportunidades del Ayuntamiento de Madrid.

Moscoso et al. (2008). Deporte, salud y calidad de vida [Sport, health and quality of life]. Barcelona: Fundación La Caixa.

Norman et al. (2007). South African Comparative Risk Assessment Collaborating Group in 2000: Towards promoting health and preventing diseases. South African Medical Journal, 97(7), 637-641.

Nowak, M. (2011). Physical Activity and its Associations with other Lifestyle Elements in Polish Women. Journal of human kinetics, 29,161-172.

Odunaiya, N.A., Aderibigbe, A.A. \& Oguntibeju, O.O. (2011). Physical exercise: knowledge, attitudes and habits of literate women in Westem Nigeria. African Journal for Physical, Health Education, Recreation and Dance, 17(4:2), 789-803.

Pitsavos et al. (2005). Epidemiology of leisure time physical activity in socio-demographic lifestyle and psychological characteristics of men and women in Greece: the ATTICA Study. BMC Public Health, 5-37.

Sahin et al. (2014). Regular Physical Activity habits in women. International Refereed Academic Journal of Sportsm,10(4), 88-97.

Schnell, A., Mayer, J., Diehl, K., Zipfel, S., \& Thiel, A. (2014). Giving everything for athletic success! - Sports-specific risk acceptance of elite adolescent athletes. Psychology of Sport and Exercise, 15, 165-172.

Stearns et al. (2000). The Economic Implications of Self-Care: The Effect of Lifestyle, Functional Adaptations, and Medical Self-Care Among a National Sample of Medicare Beneficiaries. American Journal of Public Health, 90,1608-1612.

Strawbridge et al. (2002). Physical Activity Reduces the Risk of Subsequent Depression for Older Adults. American Journal of Epidemiology, 156(4), 328-334.

USDHHS (2008). Physical Activity Guidelines Advisory Committee Report, 2008. Washington, DC: United States Department of Health and Human Services. http://www.health.gov/paguidelines/guidelines/. (Accessed 18th October 2015)

\section{Authors}

MARIA ESPADA, Doctora en Ciencias de la Actividad y del Deporte, Profesora Ayudante Doctor de la Facultad de Ciencias de la Actividad Física y del Deporte (INEF) de la Universidad Politécnica de Madrid, miembro del Grupo de investigación psicosocial en el deporte de la UPM. Sus principales líneas de investigación se enfocan en la educación y las ciencias sociales aplicadas a la actividad física y el deporte. ORCID: https://orcid.org/0000-0002-3815-1037

MARÍA MARTÍN RODRÍGUEZ, Doctora en Ciencias de la Actividad y del Deporte, Profesora Titular de la Facultad de Ciencias de la Actividad Física y del Deporte (INEF) de la Universidad Politécnica de Madrid y responsable de la 
línea de investigación sobre Igualdad de género en el deporte del Grupo de investigación psicosocial en el deporte UPM. Sus intereses se orientan a la investigación social aplicada al deporte, con especial atención a las mujeres y la salud.

VÍCTOR JIMÉNEZ Graduado en Ciencias de la Actividad Física y del Deporte por la Universidad de Castilla-La Mancha, Máster en Organización, Gestión y Administración de Entidades y Organizaciones Deportivas por la Universidad Politécnica de Valencia, y Máster en Ciencias de la Actividad Física y del Deporte por la Universidad Politécnica de Madrid. Profesor en la Facultad de Educación y Salud de la Universidad Camilo José Cela y del Máster Universitario en Dirección de Organizaciones e Instalaciones de la Actividad Física y del Deporte. Sus líneas de investigación son la organización de programas de ejercicio físico en centros de trabajo.

DAVID MOSCOSO. Doctor en Sociología, Profesor Titular del Departamento de Sociología de la Universidad Pablo de Olavide. Sus líneas de investigación en el ámbito de la sociología del deporte son género y generación, inclusión y diversidad social, y desarrollo rural y deportes de naturaleza.

ORCID: https://orcid.org/0000-0003-4135-1475

EMILIO JIMÉNEZ-BEATTY, Doctor en Ciencias de la Actividad Física y del Deporte y Máster en Dirección de Organizaciones e Instalaciones Deportivas. Profesor Titular de Facultad de Medicina y Ciencias de la Salud de la Universidad de Alcalá. Especialista en planificación y gestión deportiva. Su actividad investigadora se ha centrado en el ámbito de la investigación social y organizativa en la actividad física y el deporte.

ANTONIO RIVERO Licenciado en CC de la Actividad Física y el Deporte (INEF, Madrid) Master en Dirección y Administración Deportiva (UCM-COE) Doctor y Licenciado en Geografía e Historia (U.C.M.) Profesora Titular de la Facultad de Ciencias de la Actividad Física y del Deporte (INEF) de la Universidad Politécnica de Madrid. Sus líneas de investigación son historia del deporte y empresas y organizaciones deportivas.

Recibido: 28-11-2017

Aceptado: 18-06-2018

(c) (i) Licencia Creative Commons Reconocimiento (CC BY 4.0) 



\title{
FROM SOCIAL MOVEMENTS TO POLITICAL
} PARTIES. BARCELONA EN COMÚ'S ELECTORAL MESSAGE, USES AND LIMITATIONS ON TWITTER DURING 2015 CITY COUNCIL ELECTION DE MOVIMIENTOS SOCIALES A PARTIDOS POLÍTICOS.
MENSAJE ELECTORAL, USOS Y LIMITACIONES DE
TWITTER POR PARTE DE BARCELONA EN COMÚ EN
LAS ELECCIONES MUNICIPALES DE 2015

\author{
Lucía García-Carretero \\ Universitat Pompeu Fabra, España \\ lucia.garcia@upf.edu \\ Javier Díaz-Noci \\ Universitat Pompeu Fabra, España \\ javier.diaz@upf.edu
}

\begin{abstract}
Cómo citar / citation
García-Carretero, L. y Díaz-Noci, J. (2018) "From social movements to political parties. Barcelona en comús electoral message, uses and limitations on Twitter during 2015 city council election". OBETS. Revista de Ciencias Sociales, 13(2): 515-545. doi: 10.14198/OBETS2018.13.2.03
\end{abstract}

\begin{abstract}
Twitter as an electoral communication tool is determined by the objectives and the character of each political organization. This article analyses the communication strategies of the political organization Barcelona en Comú on Twitter for a better understanding of the way in which new political forces work in a digital environment. The case study is based on qualitative content analysis with several categories related to the message and the digital network possibilities. The amount of 1,840 tweets from two groups of Twitter accounts was analyzed. First, the tweets disseminated by the six parties that form the electoral coalition Barcelona en Comú. Second, the tweets disseminated by politicians and members of communication commission of the parties. The results allow
\end{abstract}


us to conclude that one of the six parties centralised the communication of the confluence. Also, that the bidirectional communication process among parties and users took place in the second group of Twitter accounts.

Keywords: Social media; Twitter; Political Communication; Online Campaigning; Digital media; Barcelona en Comú.

\section{Resumen}

El uso de Twitter como herramienta de comunicación electoral se encuentra determinado por el carácter de cada organización política. Este artículo analiza las estrategias comunicativas electorales en Twitter de la organización política Barcelona en Comú con el fin de averiguar cómo las nuevas formaciones políticas actúan en el medio digital. El presente caso de estudio se basa en un análisis de contenido cualitativo centrado en diferentes categorías en relación al tema de campaña y a las posibilidades que la red digital ofrece. El universo de estudio son 1.840 tweets organizados en dos niveles de análisis. En primer lugar, los tweets difundidos por las cuentas de los seis partidos que forman la coalición electoral Barcelona en Comú. En segundo lugar, los tweets publicados durante la campaña por las cuentas de los candidatos y miembros de la comisión de comunicación. Los resultados muestran como uno de los seis partidos de Barcelona en Comú centralizó la comunicación durante la campaña. Asimismo, se confirma que el proceso de comunicación bidireccional en Twitter se llevó a cabo mediante los perfiles en la red social de políticos y miembros de los grupos de comunicación de los partidos.

Palabras clave: Medios sociales, Twitter, comunicación política, campaña online; medios digitales, Barcelona en Comú.

\section{INTRODUCTION}

This article seeks to analyze the electoral communication characteristics on Twitter of the electoral coalition Barcelona en Comú from $8^{\text {th }}$ to $22^{\text {nd }}$ of May 2015. The main purpose is to analyze the online communication strategy for a better understanding of the way in which new political forces, which appeared in a digital environment, use digital networks. More specifically, this research study is included in broader research based on a mixed-method approached (Edwards, 2010). The methodological design of this paper is based on a qualitative content analysis. This technique has been applied to two levels of Twitter accounts during the electoral campaign. In order to go in-depth into the first level (1,195 tweets), we analyze the six political parties of the electoral coalition. Also, we study a second level of analysis of 645 tweets spread by other relevant actors such us the politicians of the confluence (e.g@AdaColau) and other users who set the electoral message on Twitter during the campaign (e.g. @3eses), based on the results of previous research (García-Carretero \& Pérez-Altable, 2017). 
The research interest in the use of Twitter as an electoral communication tool has increased substantially in last years (Fenton \& Barassi, 2011; Vaccari, 2013; Bor, 2014; Jungherr, 2015; Campos-Domínguez, 2017). This has contributed to the debate on the potential of social networks as a communication channel in a hybrid media system (Chadwick, 2013), where offline and online forms of communication take place at the same time. Moreover, in political communication "older and new media [...] are on balance, more expansive and inclusive than those that prevailed during the twentieth century" (Chadwick, 2013, 210). The use of social media depends on parties' characteristics and on their adaptation of the parties to the digital communication according to their goals, organization and power situation (Borge \& Esteve, 2017). For that matter, a research based on the Spanish 2016 election, shows the media hybridization and differences among parties characteristics (López-Meri, Marcos-García \& Casero-Ripollés, 2017). The use of social media offers both challenges and opportunities in online political communication (Borge \& Esteve, 2017). In this process, the definition of the objectives, political agenda and the design of ideal communication strategies are essential features to influence citizens' behavior (Maarek, 1997). Thus, "politicians are compelled to pay special attention to what circulates on social networks, to the issue raised and debated by the citizens, and to sense the pulse of public opinion now more unpredictable and volatile than ever before" (Mazzoleni, 2017: 7).

The Spanish social movements were born out of the economic crisis (della Porta \& Mattoni, 2014; Casero et al., 2017) such as The Platform of Mortgage Victims (PAH, according to the Catalan/Spanish spelling) or Indignados movement (Royo, 2014) and introduced a different language and a variety of actions into the public scene (Sampedro \& Sánchez-Duarte, 2011; Flesher \& Montañés, 2014; Casero et al, 2017). The social movements against austerity (della Porta $\&$ Mattoni, 2014) also set a political opportunity for new political parties both in a national and supranational level (Mosca, 2014). In this context, new leftwinged political parties arose in the framework of Mediterranean Europe as Movimento 5 Stelle in Italy, Syriza in Greece, or Podemos in Spain (Auriemma et al., 2015; Poulakidakos \& Veneti, 2016). Spanish national party Podemos (We can) and other local and regional organisations so-called "the commons" that appeared at Post 15M context (Sanz \& Mateos, 2014) crystallised the Spanish social protests in terms of political opportunities. For instance, the political organisations born in 2015 such us Ahora Madrid (Now Madrid) in Madrid, En Marea (En Masse) in Galicia or Barcelona en Comú (Barcelona in Common) in Barcelona (Lobera, 2015; della Porta, Fernández, Kouki \& Mosca, 2017). 
This research study assumes that Barcelona en Comú is a representative example and a case study (Yin, 2009) of movement parties against austerity in Europe and Western World (della Porta, et al., 2017). These are "political parties that have particularly strong organizational and external links with social movements" (della Porta et al. 2017: 4-5). Guanyem Barcelona, currently Barcelona en Comú, was formed in June 2014. Less than one year after its creation, this movement party (della Porta et al. 2017) joined with other five left political parties and formed the confluence Barcelona en Comú ${ }^{1}$. The so-call confluence was formed by the parties Barcelona en Comú -new movement party-, Iniciativa per Catalunya Verds and Esquerra Unida i Alternativa -left-wing minority parties-, Podem -the Catalan We Can-, EQUO -green party-, and Procés Constituent -a left-winged independence Catalan party-. These parties ran in the city council election of May 2015. Finally, on 24 May 2015 Barcelona en Comú won the municipal elections being elected with 11 seats. Nowadays, Ada Colau is the Mayoress of Barcelona, who used to be the spokeswoman of PAH social movement.

Nonetheless, the relevance of Spanish social movements is not only their political opportunity (Mosca, 2014; della Porta et al., 2017). Spanish social movements found in social media a complementary organization and communication channel in addition to mass media coverage (Linares \& Pérez-Altable, 2015; Linares, 2017). Also, these new left-wing political parties inhered the communication practices, tools as digital networks and most of the leaders of social movements (Borge \& Santamarina, 2015) given its lack of hegemony at the public sphere.

\section{SOCIAL AND POLITICAL CONTEXT: FROM SOCIAL MOVEMENTS TO NEW POLITICAL PARTIES}

In Spain, as in many other European countries (Auriemma et al., 2015; Poulakidakos \& Veneti, 2016; della Porta et al., 2017), the economic crisis situation started between the end of 2007 and the beginning of 2008 (Carballo-Cruz, 2011; Orriols \& Cordero, 2016). The financial and economic breakdown has produced, as many other results, a climate of distrust and political disaffection amongst wide layers of the population, singularly the youngest ones (Calvo, Gómez-Pastrana \& Mena, 2011; Likki, 2012; Fernández-Planells, Figueras-Maz $\&$ Feixa, 2014). The economic crisis that concerned Spanish citizens and the

${ }^{1}$ The parties decided to call itself confluence because this word symbolized, according to Barcelona en Comú, the union among left parties. Nevertheless, the proper expression to define this group of parties is an electoral coalition of parties. 
disaffection with the political system were essential features for the outbreak of protests (Castells, 2012; Alonso \& Rovira, 2015; Gerbaudo \& Screti, 2017). The best-known manifestation of social movements against austerity (della Porta \& Mattoni, 2014) was the Indignados movement. In May 2011, massive concentrations took place in Spanish cities such as Catalunya and Sol squares in Barcelona and Madrid. Another example of the inequality rising (Roos \& Oikonomakis, 2014) is the Platform of Mortgage Victims (PAH), whose spokeswomen and activist was Ada Colau. Ada Colau is nowadays is the Mayoress of Barcelona. The PAH "found in the web 2.0 and social networks a useful tool to communicate and mobilize [...] and introduce their topics and frames in political and media agenda-setting" (Alonso-Muñoz \& Casero-Ripollés, 2016: 26).

Moreover, this cycle of mobilizations as a consequence of multi-dimensional crisis "have also contributed to change in the Spanish political system" (della Porta et al., 2017: 46) and given roots for new political parties (Bosi, Giugni \& Uba, 2016, López-García, 2017). These social movements broke "the social and political consensus established in the political transition" and led the political opportunity (della Porta et al., 2017: 45). As a consequence, "processes of movements' institutionalization have taken place with democratization waves throughout the world" (Doowon, 2006, in Piccio, 2016: 265). Between 2014 and 2015, political organizations like Podemos burst into the Spanish system because of social movements' political changes (Sanz \& Mateos, 2014). Up until that moment, the Spanish political system was characterized by the alteration of two main parties in the Government (Orriols \& Cordero, 2016). The relationship between social movements and parties can lead in a context where movements join electoral parties or coalitions (McAdam \& Tarrow, 2010). The Indignados movement has not disappeared but diluted resulting in these new political organizations (Casero-Ripollés, Feenstra \& Tormey, 2016). For this reason, is highly important to figure out how the social media practices of these organizations are more structured with organizational routines and formal communication channels (Mattoni \& Treré, 2014).

\section{SOCIAL MEDIA AND POPULISM AS COMMUNICATION STYLE}

The six parties' communication strategies analyzed in this article are understood as populist communication style. As stated above, Podemos and the other local and regional movement parties as Barcelona en Comú (della Porta et al. 2017) are based on populist communication strategies (López-García, 2017), according to Ernesto Laclau's (2005) and Antonio Gramcsi's (2009) work. In European populist atmosphere, the Spanish left-wing populism is interesting in a con- 
text where right-wing populism is dominant (Casero-Ripollés, Sintes-Olivella $\&$ Franch, 2017). Despite the difficulty to define what populism is (Laclau, 2005), populism denies the left-right dichotomy, it is multiclass and demands equal political rights, social justice and participation of ordinary people against privileged groups (Germani, 2003). Nevertheless, the overcoming of the rightleft binomial as well as the overcoming of the class struggle for this case study is questioned. According to the authors (Aalberg, Esser, Reinemann, Strömbäck \& De Vreesee, 2017; Block \& Negrine, 2017), populism can be understood as a political (communication) style due to "the effect of the mediatisation of the political equating to a simplification of political discourse, it's the reduction to neat us-against-them antagonisms and sound-bite solutions" (Moffitt \& Tormey, 2014: 7). Many elements defined populist political communication style. For instance, the construction of "the people", the anti-elitism and "the people" against "the elite" and, among others, the "crisis" as a central point in the shape of the message (Jagers \& Walgrave, 2007; Moffitt \& Tormey, 2014; Rooduijn, 2014).

In addition, this kind of political communication is related to the theoretical concept of mediatisation of politics (Strömbäck, 2008; Landerer, 2013; Mazzoleni, 2017). Mediatization is a "process of communicative construction of socio-cultural reality" (Couldry \& Hepp, 2013: 196). Hence, mass media are relevant because "they have gained central position in most political routines, as election campaigns" (Mazzoleni, 2008: 3048). In this line, as Bennett and Iyengar (2008) pointed out, media are a part of the political governing process due to its macro-oriented or institutional approach to communication and the variations in the organization, regulation or structure of the media can be an influence to the citizens and the elites.

However, a review of the concept of mediatisation is necessary (Mazzoleni, 2008). This process of communication "cannot be understood without considering the larger context of a world of being integrated technologically, economically, and culturally" (Landerer, 2013: 240). In this sense, social media and mass media have some different characteristics that "makes them distinct engines of the digital public sphere where players engage in dialogical tugs-of-war in the power game" (Mazzoleni, 2017: 142). The so-called alternative or new media are also social spaces where "everyday space in the digital era is not just mediated but 'networked', that is, its action-possibilities are structured by hierarchical and differentiating work of informational networks" (Couldry \& Hepp, 2017: 99). Political parties on social networks, particularly on Twitter, are able to spread and manage their political program without mass media despite the power of social media remains at social networks too (Fenton $\&$ Barassi, 2011). Nevertheless, it is interesting to ask whether the parties and 
candidates take advantage of the -theoretical- lack of intermediaries in the communicative process. As Chadwick sets:

Power in political communication is relational. It is shaped by hybrid networks of social and technological actants whose agency derives from their independence with other social and technological actants in interactive exchanges (2013: 207)

This communication style contributes to "the power game" (Mazzoleni, 2017: 142) based on the articulation of hegemony and counter-hegemony relation (Laclau \& Mouffe, 2001; Laclau, 2005). Hegemony is a type of relation or a political form, with an open and incomplete nature constituted by the antagonisms articulations and frontiers (Laclau \& Mouffe, 2001). The constant redefinition of the hegemony is based on democratic struggles and the difficulty to articulate the system of relations (Laclau \& Mouffe, 2001). In this context, political communication articulates this system of relations. The power relation in political communication is played by two differentiated groups of parties. On one hand, the traditional parties are considered the historical block (Gramsci, 2009) or the hegemonic formation (Laclau \& Mouffe, 2001). On the other hand, the minor or new parties are the counter-hegemonic (Laclau \& Mouffe, 2001).

Television is the main political communication mass medium in Spain (Sampedro, Sánchez-Duarte \& Campos, 2014). Nonetheless, state television time during the Spanish electoral campaign depends on the previous election result according to the LOREG Act ${ }^{2}$. Thus, in the state television coverage "major national and regionalist/nationalist parties have greater coverage in the traditional media than minor/news parties" (Aragón, Kappler, Kaltenbrumer, Laviado \& Volkovich, 2013: 184). Nonetheless, the private television channels are not bound to Act enforcement. In this sense, "the digital landscape provides populist parties with the ability to determinate autonomously their own communicative strategies and then disseminate their discourse and narratives" (Casero-Ripollés et al., 2017). The starting point of this research is that the minor or new parties such as Barcelona en Comú confluence articulate the hegemony in social media, assuming that mass media and social media can coexist (McNair, 2006; Chadwick, 2013; Casero-Ripollés et al. 2016).

\section{TWITTER AS AN ELECTORAL COMMUNICATION TOOL}

Political communication "is critical to the ongoing process of building society and it is considered as an activator that permits two-way communication

\footnotetext{
${ }^{2}$ Organic Act of General Electoral System/Ley Orgánica del Regimen Electoral General.
} 
and participation among members of a society and between different societies" (Holba, 2010: 23). As a consequence, "is not a coincidence that the increased availability of news sources has been accompanied by increasing polarization" (Bennet \& Iyengar, 2008: 720). Even if the most common example regarding online electoral communication is Barack Obama's campaign in 2008 (Nielsen, 2012), there are some factors such as the technological development, the socio-political environment and the party characteristics that determinate the use of social media (Vaccari, 2013). As the author suggests, "the distance between the United States and other countries in this respect is even larger than in terms of the sophistication of the parties and candidates [...]" (Vaccari, 2013: 134). In summary and according to Couldry's (2015) work, in this article digital networks are understood as a tool of political and social mobilization, protest, collective organization and action, but no as a substitute for social or political practice, and foremost, a substitute of other ways of political communication.

The first time that digital tools were capitalized by political parties in Spain was in 2004 and 2008 elections (Sampedro, 2011). Moreover, the use of Twitter as a political communication tool in Spain has been significantly higher since the Spanish protests between 2011 and 2013 (Aragón et al, 2013). Recent studies have explored the use of Twitter as a political communication tool in Spain in regards to council election (Carratalá \& Galán, 2016; Quevedo, Portalés-Oliva \& Berrocal, 2016), regional election (Pérez \& Nicasio, 2015; LópezGarcía, Cano \& Argilés, 2016; Marín \& Díaz, 2016) and general election (Sampedro, 2011; Aragón et al, 2013; Zugasti \& Sabés, 2015; Alonso-Muñoz, Marcos-García \& Casero-Ripollés, 2016; Campos-Domínguez \& Calvo, 2017; Casero-Ripollés et al., 2017; López-García, 2016). Also there are works related to the use of Twitter in relevant political moments in Spain (Marcos-García, Alonso-Muñoz \& Casero-Ripollés, 2017). Scholars have especially focused on two uses of Twitter in political communication, one related to the politicians' and other related to the citizens' (Zugasti \& Sabés, 2015; Tromble, 2016). One of these previous studies was done by Aragón, Volkovich, Laviado and Kaltenbrumer (2015). The authors argue that Barcelona en Comú has two different groups in Twitter: one controlled by the candidate and the political party and other made up of activists (Aragón et al., 2015).

The debate on the potential of social networks in political communication is common. "In the social sciences, there is much disagreement on the political possibilities offered by social media" (Fenton \& Barassi, 2011: 180). In this line, it is necessary to differentiate what participation and interaction are. Participation is not only the access to media; it also requires a bidirectional process of communication (Carpentier, 2015). In addition, "different media practices 
enable different forms of participation" (Fenton \& Barassi, 2011: 180). Thereby, "the adoption of digital media candidates may simply have been premature because fully implementing innovations through complex organizations requires time" (Vaccari, 2013: 50). Only if social networks are based on dialogue and participation, they can be understood as the maximum expression of Web 2.0 (Zugasti \& Sabés, 2015). Twitter is not only a tool to spread propaganda but also a tool to generate a space of debate between politicians or parties and citizens (Aragón et al., 2013). Nonetheless, digital networks do not provide any guarantee of the bi-directional communication process (LópezGarcía et al, 2016). Once the novelty of digital networks has been overcome, it is considered essential to reflect on their multi directionality and their 'democratizing power'.

\section{RESEARCH DESIGN AND METHODS}

The main objective of this research study is to deepen on the electoral communication characteristics on Twitter of the confluence Barcelona en Comú. For that purpose, we analyze the corpus of tweets disseminated by the six parties that formed the confluence Barcelona en Comú during Barcelona city council election. Thus, the 1,195 tweets disseminated from $8^{\text {th }}$ to $22^{\text {nd }}$ of May 2015 by the parties Barcelona en Comú (BeC), Iniciativa per Catalunya Verds (ICV), Procés Constituent (PC), Podem (P), Esquerra Unida i Alternativa (EuiA) and EQUO (E). In a previous research (García-Carretero \& Pérez-Altable, 2017) we explore the confluence behaviour on Twitter and both the interaction between the parties and with the users using explorative social network analysis (SNA). We observed that there is another group of users who also set the electoral message. For that reason, in addition, we analyse 645 tweets disseminated by @AdaColau,@G_Pisarello,@Laiaortiz,@janetsanz, @3eses and @jaumeasens. In agreement with Edwards, we consider that "SNA represents a specific opportunity to mix methods because of its dual interest in both the 'structure' or 'form' of social relations (2010: 4-5). In brief, we use qualitative content analysis with the aim "to supplement its procedures for mapping and measuring networks with more qualitatively sensitive forms of analysis" (Edwards \& Crossley, 2009: 40).

Firstly, this article attempts to identify (O1) the electoral communication strategy according to the message. In other words, find out the thematic selection, the kind of message and if the text electoral message corresponds to the hashtag used. As it has been mentioned, this research study presents the results of qualitative content analysis with the aim of makes inferences from the text (Krippendorff, 2013). Previously, a pre-test was made in order to define the 
content analysis categories. Taking into account the speaker(s), the receiver(s) and the message (Colle, 2011), we used a thematic analysis (Bardin, 2002) to know the campaign issues on Twitter and the context or frame of those issues (Goffman, 1986). Being in agreement with Van Gorp's constructionist approach, the concepts "become frames when someone applies them for their defining capacity" (2010: 88). Several political communication studies use frame analysis (Gitlin, 1980; Entman, 2004; Lakoff, 2004). Thus, we refer to collective action frames, which "organize experience" and "guide action" (Benford \& Snow, 2000: 614). Consequently, we attempt to know how Barcelona en Comú relates their main campaign issues, the cause of the problems, consequences and solutions (Entman, 1993). With the purpose of finding the intention of political parties' communication out, we use the speech acts of Austin (2003) and Searle (1976). We refer to the categories (1) directive, acts when the speaker affirms or denies anything certainly; (2) commissive, when the speaker is committed to future action; (3) expressive, when the speaker express emotions; (4) declaration, act when the speaker is committed to change the reality; and (5) assertive, acts that commit the speaker to the truth of the expressed. However, in agreement with Searle (1976), every expression has an illocutionary force but does not necessarily has propositional content. In addition, verbs are not the only sign of illocutionary force (Alarcón, 2008) and it is possible that several tweets do not have a verb. We use the classification of Lobera (2010) to deepen digital participation. According to the author, there are five sorts of digital participation related to their use and the kind of the social network or online tool used by the political parties. Nevertheless, in this investigation the communication channel is Twitter, so we classify the tweets in connection with their use: (1) information, (2) communication, (3) deliberation, (4) enquiry/decision making and (5) creative action (Lobera, 2010).

Secondly, we analyze (O2) communication possibilities related to the use of Twitter by the six parties in relation to the images, videos or links. Besides, we explore some Twitter possibilities, for example, the number of likes or favorites (Fav), retweets (RT) and the hashtags (\#) used by the political parties.

Thirdly, according to the replies to the parties' tweets, (O3) we analyze the kind of conversation between the political parties of the confluence and Twitter users. The aim is to find out whether is a bidirectional communication between parties and citizens during the electoral campaign. In this sense, several authors have noticed the limitations on the use of digital networks as a bidirectional communication channel (Graham, Broersma, Hazelhoff, Van't Haar, 2013; Jungherr, 2015) because the power, economic and political offline structures prevail (Lilleker, Koc-Michalska \& Schweitzer, 2011). To analyze 
the users' replays we focus in the classification proposed by Freelon (2010) and further expanded by López-García and Valera-Ordaz (2015). Also, ascertain if the replies of the users introduce a new issue (micro issue) and if political parties participate in the conversations generate as a consequence of their tweets. We also investigate the users' comments. In accordance with this taxonomy (Freelon, 2010, López-García \& Valera-Ordaz, 2015), there are three models of conversations, thereby three models of democracy (Table 1).

Finally, following the previous social network analysis (García-Carretero \& Pérez-Altable, 2017), this article also analyses (O4) the message of other users both politicians and citizens, which set the political message of the confluence during the electoral campaign. Hence, this article goes in-depth into two levels of the electoral campaign on Twitter analyzing the different electoral issues. On one hand, we analyze the Twitter accounts of the six political parties or

Table 1. Three models of online democratic communication

\begin{tabular}{|c|c|c|}
\hline $\begin{array}{l}\text { Model of democratic } \\
\text { communication }\end{array}$ & Definitional variables & Sub variables \\
\hline Liberal individualistic & $\begin{array}{l}\text { Monologue } \\
\text { Personal revelation } \\
\text { Personal showcase }\end{array}$ & \\
\hline Communitarian & $\begin{array}{l}\text { Ideological homophile } \\
\text { Mobilization } \\
\text { Community identification }\end{array}$ & $\begin{array}{l}\text { Focused opposite } \\
\text { Opposite } \\
\text { Neutral } \\
\text { Favorable } \\
\text { Positive } \\
\text { Focused positive }\end{array}$ \\
\hline \multirow[t]{2}{*}{ Deliberative } & $\begin{array}{l}\text { Arguments } \\
\text { Reciprocity }\end{array}$ & $\begin{array}{l}\text { No answer/Don't know } \\
\text { Hard language } \\
\text { Reply with arguments }\end{array}$ \\
\hline & Discursive freedom & $\begin{array}{l}\text { Neutral language } \\
\text { Hard language } \\
\text { Hard language with speakers }\end{array}$ \\
\hline
\end{tabular}

López-García \& Valera-Ordaz (2015) basing on Freelon (2010) 
Table 2. Main users on Twitter setting Barcelona en Comú message

\begin{tabular}{l|l|l|l|lll}
\hline Position & Twitter account & Node & Level & N & Tweets/day & In-degree \\
\hline 1 & @bcnencomu (BeC) & MN & First & 570 & 37.87 & 1,263 \\
\hline 2 & @adacolau & SN & Second & 66 & 4 & 880 \\
\hline 3 & @g_pisarello & SN & Second & 22 & 1.33 & 132 \\
\hline 4 & @laiaortiz & SN & Second & 51 & 2.8 & 115 \\
\hline 6 & @janetsanz & SN & Second & 117 & 14.26 & 64 \\
\hline 7 & @3eses & SN & Second & 317 & 19.4 & 61 \\
\hline 8 & @jaumeasens & SN & Second & 72 & 3.33 & 61 \\
\hline 17 & @iniciativabcn (ICV) & MN & Second & 334 & 22.33 & 58 \\
\hline 113 & @podem_bcn (P) & MN & First & 100 & 6.66 & 26 \\
\hline 126 & $@$ euiabcn (EUiA) & MN & First & 38 & 1.86 & 3 \\
\hline 549 & @equobcn (E) & MN & First & 11 & .88 & 0 \\
\hline & & & & 1840 & & 4 \\
\hline
\end{tabular}

main nodes (MN) and politicians' accounts or secondary nodes (SN). On the other hand, we focus on other Twitter accounts (also SN) that set the message. Table 2 shows ten different actors or nodes in the top of the classification, but we also include the other political parties' account of the confluence although with the lower range of in-degree. The lower range of in-degree indicates the connections received by a node (Freeman, 1979).

\section{FINDINGS}

\subsection{First level of analysis: political parties}

\subsubsection{The message}

Before specifying the thematic selection during the electoral campaign, it needs to be emphasized that the six parties of the confluence disseminated a big amount of electoral issues (Figure 1). First of all, the main common issue disseminated by the six parties is a call for public meetings or speeches at the urban area, election debates in the mass media and another kind of announcement of the 
campaign $(\mathrm{BeC}=22.18 \% ; \mathrm{ICV}=24.77 \% ; \mathrm{PC}=42.10 \% ; \mathrm{P}=21 \% ; \mathrm{EUiA}=42.85 \%$; $\mathrm{E}=27.27 \%)$.

Figure 1. Electoral issues disseminated by the six parties

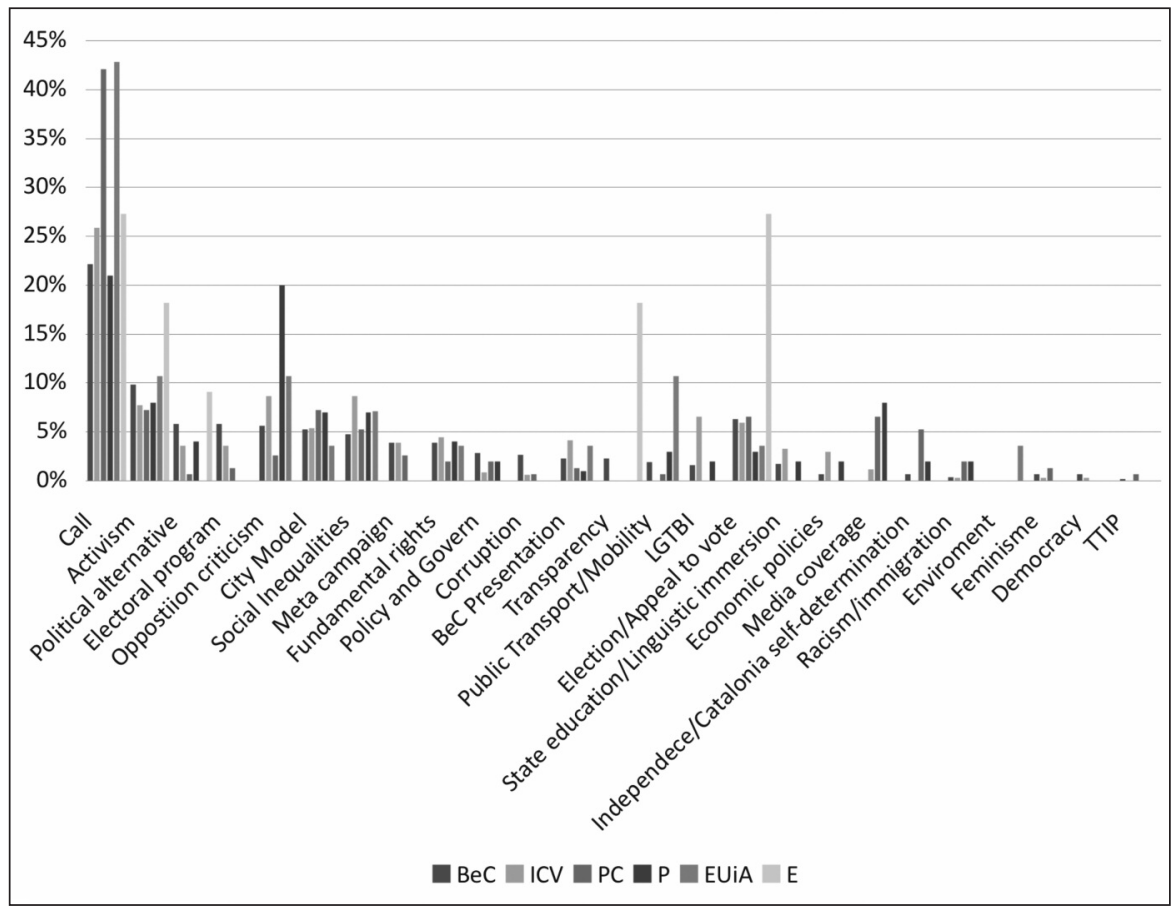

As it has been observed, activism or citizen participation was the second common issue placed by the six parties ( $\mathrm{BeC}=9.86 \% ; \mathrm{ICV}=7.76 \% ; \mathrm{PC}=7.23 \% ; \mathrm{P}=8 \%$; $\mathrm{EUiA}=10.71 \% ; \mathrm{E}=18.18 \%)$. Subsequently, social inequalities and election and appeal to vote were the third and the fourth main issues during the electoral campaign. The social inequalities issue was disseminated by ICV (8.65\%), P (7) and EUiA (7.14\%) while election and appeal to vote was more relevant for the thematic selection of BeC party (6.33\%), PC (6.57\%) and EQUO (27.27\%).

In this research, we consider that some issues are more relevant during the electoral campaign than others. The tweets related to proposals and objectives for a future management of the municipal council are relevant. As Figure 1 notes, some of these issues are the electoral program and the ethical code, the tweets based on the election and the appeal to vote and what the confluence of parties of $\mathrm{BeC}$ is (presentation). Electoral program and the ethical code was spread only for BeC (5.83\%), ICV (3.58\%) and PC (1.31\%). The rest of the parties did not refer to this issue. Regarding the presentation of the confluence, the only 
party that did not spread this issue was EQUO. In contrast, it was disseminated by ICV (4.17\%), BeC (2.28\%), PC (1.31\%), Podem (1\%) and EUiA (3.57\%). Also, some tweets are based on the issue political situation and the necessary change and political alternative and place Barcelona en Comú confluen$c e$ as the actor of this process: BeC (5.83\%), ICV (3.58\%), Podem (4\%), PC (0.65\%) and EQUO (9.09\%).

Another characteristic of the electoral campaign is the attack on the opposition and the negative campaign (Auter \& Fine, 2016; Gross \& Johnson, 2016). In this line, the parties used the opposition criticism issue, especially to criticise the social inequalities as a consequence of their political management $(\mathrm{BeC}=$ $5.63 \% ; \mathrm{ICV}=8.65 \% ; \mathrm{P}=20 \% ; \mathrm{PC}=2.63 \% ; \mathrm{EUiA}=10.71 \%$ ). In addition, it has been possible to differentiate a group of issues in which social content predominates. So, during the electoral campaign, the confluence focused on public education and linguistic immersion, Lesbian, Gay, Transgender, Bisexuals and Intersex, racism and immigration, Spanish historic memory or feminism and inequality.

In order to determine the efficiency of each electoral issue, we used the equation proposed by Alfredo Morales-Guzmán, Javier Borondo-Benito and Rosa M. Benito (2014):

$$
e=\frac{i}{a}
$$

According to the authors, efficiency is the ratio between influence gained and the effort of the political parties spreading the electoral message (MoralesGuzman et al, 2014; García-Carretero \& Pérez-Altable, 2017). For this paper, ' $i$ ' is the number of interactions understanding interactions as the retweets + likes that a tweet received, and ' $a$ ' understood as s the number of tweets disseminated by the parties about an electoral issue.

Table 3. Efficiency of electoral campaign issues

\begin{tabular}{l|l|l|l|l|l|l}
\hline & $\mathrm{BeC}$ & $\mathrm{ICV}$ & $\mathrm{P}$ & $\mathrm{PC}$ & $\mathrm{EUiA}$ & $\mathrm{E}$ \\
\hline Call & 4,8 & 4,1 & 9,3 & 6 & 0,5 & 6,3 \\
\hline Activism/Citizens participation & 40,4 & 2,2 & 9,8 & 10,3 & 1,5 & 1,5 \\
\hline Social inequalities & 51,2 & 4,2 & 11,4 & 11,7 & & \\
\hline Election/Appeal to vote & 24,3 & 4,6 & 6,3 & 9 & 6,3 & 6,3 \\
\hline Electoral program & 34,7 & 3,7 & & 2 & & \\
\hline Opposition criticism & 67,4 & 9,9 & 17,3 & 11.8 & & \\
\hline
\end{tabular}

$\mathrm{e}>\mathrm{l}=$ efficient $; \mathrm{e}<\mathrm{l}=$ no efficient 
As can be seen from Table 3, most of the main campaign issues -according to the number of tweets spread about this issue and the engagement receivedare efficient, excluding EUiA. Highlights especially the participation received in the tweets based on criticism of the opposition

Once the campaign issues have been identified, we explain the intention of the political party according to the speech acts classification. According to the confluence strategy, in five of the six political parties (Figure 2) the assertive acts, in other words, a way to commit the speaker to the truth of the expressed (Austin, 2003; Searle, 1976), predominates (BeC=50.79\%; ICV= 61.07\%; $E=54.54 \%$; $\mathrm{P}=65 \%$; $\mathrm{EUiA}=53.57 \%$ ). However, $\mathrm{PC}$ affirms or denies anything certainly, according to directive acts definition in $50.65 \%$ of the tweets.

Figure 2. Speech acts of political parties' tweets

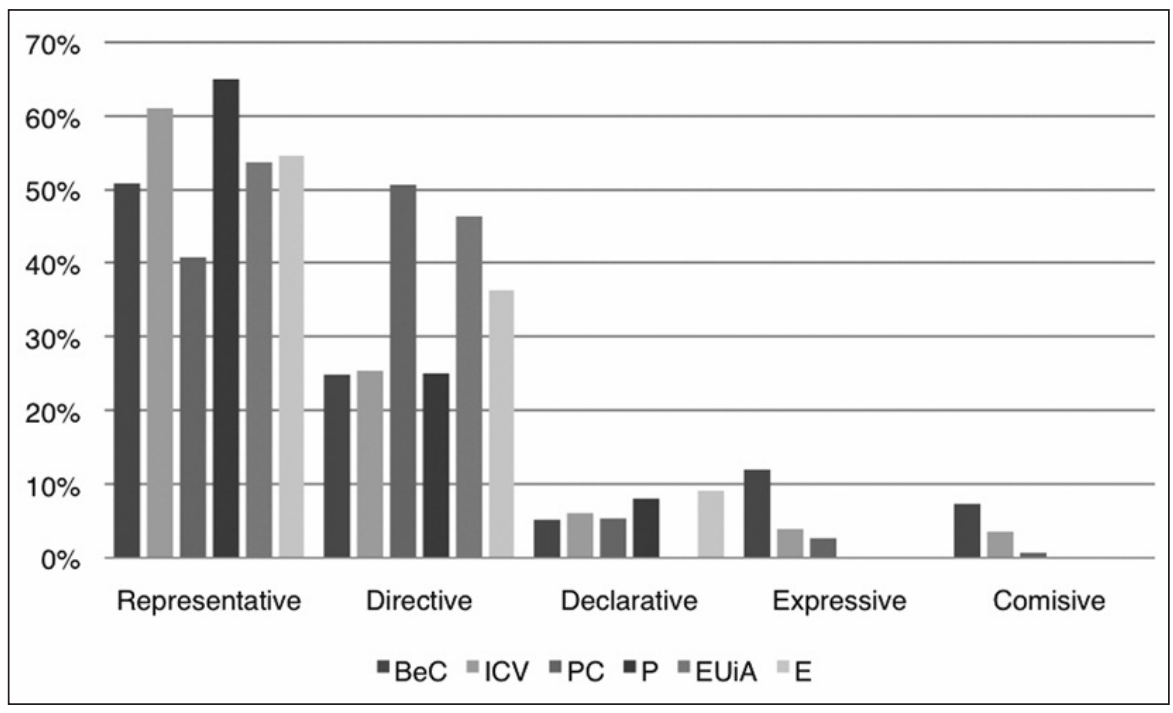

Lastly, regarding the framing of the tweets, the intention of Barcelona en Comú when disseminated tweets of call, was only to attract its target audience to a framing as a fight to recover the public places by the work of the neighbors and the "common" people. The appeal to vote, a directive act too, is framed as the only possibility or the force driving a real change, the hope for a future and the governance of the majority that is the citizenship. The tweets related to the electoral program show categorically that the program is a plan, agreement, stimulus or priority to dignify the policy and to combat social inequalities. Besides, it has observed that the intention of the confluence Barcelona en Comú when 
spreading tweets related to the activism issue was to assert that the citizenship is the protagonist and it is characterized by the political participation, the neighborhood fights and, because of that, the governments must consider it. In the same line, the political change or alternative is defined as a consequence of the activism or a powerful citizenship, which marks a break with previous policy and promotes a change comprehended as a democratic revolution.

\subsubsection{Twitter possibilities}

According to the categories of Twitter possibilities, in BeC electoral communication the use of images $(60.84 \%$ ) besides of videos $(4.76 \%)$ predominates and the use of hashtags (86.24\%) is a usual practice. In respect of links used, only a $16.57 \%$ do not have. In ICV images (35.62\%) prevail over videos $(2.09 \%)$, whereas both are not dominant. Links were added to in a $19.76 \%$ of the tweets and the hashtags in a $74.55 \%$ of the cases. In PC electoral communication, we find that images $(66.44 \%)$ are most common in the messages than videos (11.84\%), hashtags are used in an $87.5 \%$ and link complete the information in a $66.44 \%$ of the cases. Then, the use of images (43\%) predominates in Podem's tweets over the use of videos (6\%). Hashtags are included in a $77 \%$ of the tweets and the links in a 19\%. Basing in EUiA's messages, on one hand, images (39.28\%) are more common than those with videos (7.14\%). On the other hand, links to complete the text of the tweets are present in $28.57 \%$ of them. Finally, we observed that all EQUO's tweets include hashtags, 9 of them link videos and $81.81 \%$ images. During the electoral campaign, 128 hashtags were disseminated by the six political parties of the confluence. Some hashtags such us \#Ada24M, \#guanyarem $24 m$ or \#guanyarembarcelona were disseminated in a crosscutting way for the parties of the confluence. In this sense, the thematic content between the hashtag and the text electoral issue is not necessarily the same. Nevertheless, the use of the hashtags followed a coordinated strategy because allow the users to find information related to an act or event through the general and cross-cutting hashtag as Image 1 shows.

\section{Image 1. Use of hashtags}

Barcelona en Comú @ @bcnencomu.21 may.2015

Cal utilitzar la taxa turística per reinvertir en els barris més afectats \#DebatBCN

\#Ada24M barcelonaencomu.cat/ca/programa/na...

Q 1 个乙 $32 \quad \bigcirc \quad 10$ 
Regarding the typology of digital communication (Lobera, 2010), it has been observed that in $\mathrm{BeC}$ party, communication (82.53\%) is the dominant kind of participation, followed by information (15.87\%), enquiries and decision-making (1.23) and deliberation (0.35\%). By contrast, this political party did not use Twitter like a creative action channel on any occasion. In the same line, in ICV tweets predominated the communication (85.97\%), following information (13.43\%) and deliberation (0.29\%). On the contrary, there is no case of enquiries and decision-making and creative action. In PC, also predominates the use of communication $(73.31 \%$ ) besides of information $(23.68 \%)$. However, the other three kinds of digital communication -deliberation, enquiries and the decisionmaking, creative action- do not appear. In the same line, Podem's digital participation is organized in communication (82\%), information (17\%) and deliberation (1\%). Regarding EUiA, we observe that the two kinds of communication were communication (71.42) and information (28.57\%). Lastly, most of the tweets of EQUO are communication $(90.90 \%)$ and the remaining are basically information $(9,09 \%)$.

The dissemination of information in Twitter -being dissemination understood in terms of retweets and likes- shows that all the tweets belonging to the Twitter of $\mathrm{BeC}$ have been retweeted and also all of them have been marked as a favorite (99.64\%). In the case of ICV, we found $80.23 \%$ tweets with retweets and $61.37 \%$ with likes. Procés Constituent diffusion is organized in an $85 \%$ of the tweets retweeted and a $61.84 \%$ of the tweets liked. Podem tweets have been retweeted in all the cases and an $89 \%$ has been marked as a favorite. In Esquerra Unida i Alternativa, the diffusion is organized in a $64.28 \%$ tweets retweeted and a $50 \%$ liked. By contrast, the diffusion of EQUO was limited by $72.72 \%$ of tweets are retweeted and a $54.54 \%$ of tweets are liked.

\subsubsection{Bidirectional communication process}

In general terms, the six parties gave no answer in the conversations arising out of their tweets (Table 3). However, there are significant differences between parties. In the case of $\mathrm{BeC}$, we observed that about half of the tweets disseminated have replies, concretely a $46.38 \%$ of them. Users always participate, although the political party answers to the users in a $12.16 \%$ and mass media only appeared in one tweet $(0.38 \%)$. In these conversations, the users introduce a new issue different of party's issue in a $26.99 \%$. The results of ICV point out that the number of replies or conversations generated around its tweets is limited. Thus, an $8.65 \%$ of the tweets have replied and a $37.93 \%$ of that introduced new issues. Users or citizens' political agents discuss in the conversation in all the cases and the political party responds in a $17.24 \%$ of the cases while 
mass media do not take part. During the electoral campaign, only a 10,52\% of the tweets from PC were replied and, in these conversations, other issues are introduced in an 18,75. The 17 of the electoral tweets from Podem are replied and only the users have participated in all of them. The digital participation is organized in an $82 \%$ of communication, $17 \%$ of the information and a $1 \%$ of deliberation. Only one of the replies introduced a micro issue. Finally and by contrast, there is only one tweet from Esquerra Unida i Alternativa which has a reply, it does not introduce a micro issue and it belongs to the user. In this line, any tweet from EQUO generates replies.

Table 3. Replies and actors on Twitter

\begin{tabular}{l|l|l|l|l|l}
\hline Tweets with replies (\%) & $\mathrm{BeC}$ & $\mathrm{ICV}$ & $\mathrm{PC}$ & $\mathrm{P}$ & EUiA \\
\hline Yes & 46.38 & 8.65 & 10.52 & 17 & 3.57 \\
\hline No & 53.61 & 91.34 & 89.47 & 83 & 96.42 \\
\hline N Replies & 1197 & 90 & 27 & 20 & 1 \\
\hline Micro issue (\%) & $\mathrm{BeC}$ & $\mathrm{ICV}$ & $\mathrm{PC}$ & $\mathrm{P}$ & EUiA \\
\hline Yes & 26.99 & 37.93 & 18.75 & 1 & \\
\hline No & 73 & 62.06 & 81.25 & 99.99 & \\
\hline Political actors (\%) & $\mathrm{BeC}$ & $\mathrm{ICV}$ & $\mathrm{PC}$ & $\mathrm{P}$ & EUiA \\
\hline Users/Citizens & 100 & 100 & 93.75 & 100 & 100 \\
\hline Mass media & 0.38 & & & & \\
\hline Political parties & 12.16 & 17.24 & 6.25 & & \\
\hline
\end{tabular}

Table 4 shows the categories and subcategories of three different models of democracy (Freelon, 2010; López-García \& Varela, 2015). The replies generated on $\mathrm{BeC}$ and ICV tweets were a majority in Deliberative Model $(\mathrm{BeC} / \mathrm{A}=2.5 \%$; $\mathrm{BeC} / \mathrm{R} 3=36.95 \% ; \quad \mathrm{BeC} / \mathrm{DF}=9.63 \% ; \quad \mathrm{ICV} / \mathrm{A}=2.22 \% ; \mathrm{ICV} / \mathrm{R}=49.99 \%$; $\mathrm{ICV} / \mathrm{DF}=12.21 \%$ ). However, the deliberative model does not necessary guarantee that the arguments of the replies were substantiated arguments. In the case 
Table 4. Kind of conversations according to the three models

\begin{tabular}{|c|c|c|c|c|c|}
\hline Political conversations $(\%)$ & $\mathrm{BeC}$ & ICV & PC & $\mathbf{P}$ & EUiA \\
\hline Individualistic model & 12.65 & 23.33 & 40.74 & 35 & 100 \\
\hline Monologue (M) & 12.19 & 22.22 & 40.74 & 35 & 100 \\
\hline Personal revelation (PR) & 0.25 & & & & \\
\hline Personal show case (PS) & 0.91 & 1.11 & & & \\
\hline Community model & 38.48 & 14.33 & 33.32 & 60 & \\
\hline \multicolumn{6}{|l|}{ Ideological hemophilia (IH) } \\
\hline Focussed opposite & 4.92 & & & 10 & \\
\hline Opposite & 11.19 & 11.11 & 3.70 & 40 & \\
\hline Neutral/No atribuible & 5.01 & 3.33 & 18.51 & 10 & \\
\hline Favourable & 12.19 & & 11.11 & & \\
\hline Focused favourable & 3.59 & & & 5 & \\
\hline Community identification (CI) & 1.42 & & & & \\
\hline Mobilization (M) & 0.16 & & & & \\
\hline Deliberative model & 48.63 & 64.42 & 44.42 & & \\
\hline Arguments (A) & 2.50 & 2.22 & & & \\
\hline \multicolumn{6}{|l|}{ Reciprocity (R) } \\
\hline \multicolumn{6}{|l|}{ NA/DN } \\
\hline Formally replied & 20.05 & 33.33 & 11.11 & & \\
\hline Reply with arguments & 16.45 & 16.66 & 7.40 & & \\
\hline \multicolumn{6}{|l|}{ Discursive freedom (DF) } \\
\hline Neutral language & 1.69 & & & & \\
\hline Hard language & 4.67 & 6.66 & 7.40 & & \\
\hline Hard language speaker & 2.67 & 3.33 & 3.70 & & \\
\hline Exceptions & 0.60 & 2.22 & 14.81 & & \\
\hline
\end{tabular}


of PC and EUiA parties, Individualistic model predominates over the rest of models ( $\mathrm{PC} / \mathrm{M}=40.74 \%$; $\mathrm{EUiA} / \mathrm{M}=100 \%)$. By contrast, the replies of Podem party were within the Community Model $(\mathrm{P} / \mathrm{IH}=65 \%)$.

\subsection{Second level of analysis}

In accordance with the secondary actors, we analyzed the Mayoress' Twitter account (@AdaColau), the Deputy Mayor's accounts Gerardo Pisarello's (@g_pisarello), Laia Ortíz’s (@laiaortiz), Janet Sanz’s (@janetsanz) and Jaume Asens (@jaumeasens)'s. Finally, we analyse the communication commission member Sergio Espín (@3eses) profile. With regard to the electoral issue, we observed many tweets with the same issue than political parties account. For example, the opposition criticism or negative campaign was relevant in the case of @janetsanz (30.77\%) and @jaumeasens (31.94\%). Nevertheless, @ada colau, @janetsanz, @jaumeasens introduced new issues. In particular, the politicians of Barcelona en Comú confluence provided personal details (e. g. Image 2, Image 3) in responding to users questions.

Furthermore, politicians used Twitter as a bidirectional communication channel to a greater extent than the replies in political parties accounts (@jau measenes=52.7\%; @janetsanz=52.13\%; @adacolau=40.9\%; @g_pisarello=13.63\%; @laiaortiz=9.8\%).

In this line, it should be pointed out that more than the half of the tweets disseminated by @3eses, member of Barcelona en Comú communication commission, are replies to other issues (69.4\%). In this case, most of the electoral

\section{Image 2. Ada Colau's tweet}

Ada Colau $\$$ @AdaColau · 15 may. 2015

En respuesta a @FelipGordillo

(4)FelipGordillo és que no tinc cap Iphone. No n'he tingut mai

$\begin{array}{lllll}4 & 1 & 0 & 1\end{array}$

Image 3. Jaume Asens' tweet

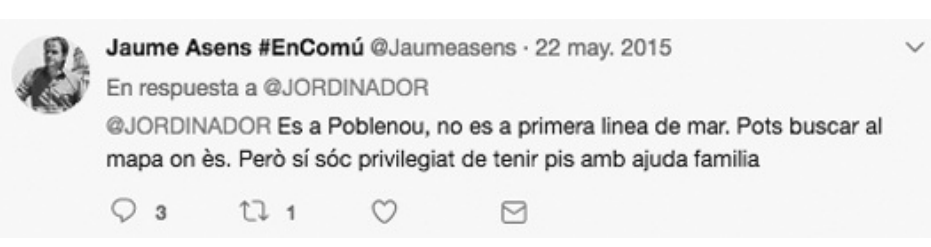


issues were in line with political parties messages $(81.7 \%)$. The three main electoral issues were the opposition criticism (22.08), the response to the criticism of the candidate Ada Colau (14.82\%), and tweets related to the electoral campaign organization (9.46\%). These two last issues from @3eses would be pointed out. First, because the main characteristic of his communication on Twitter was the roll to respond the users/citizens criticism with arguments like the link to the electoral program or another kind of information. At the same time, his replies show more freedom of speech (Image 4) because he was not a politician. Also, @3eses introduced information about the meta-campaign or how the confluence organized the communication.

\section{Image 4. Tweet from @3eses}

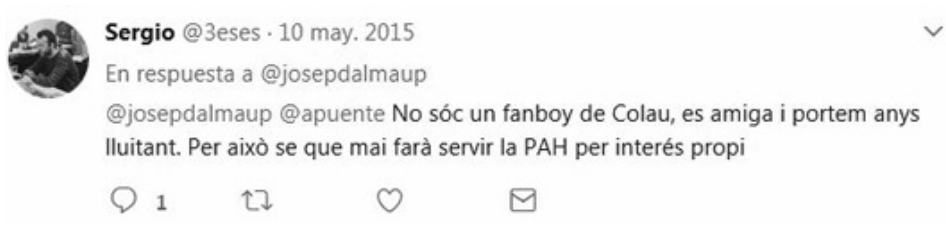

\section{CONCLUSIONS, LIMITATIONS AND FURTHER RESEARCH}

The results of our case of study allow us to conclude that the political party Barcelona en Comú (BeC) centralized the electoral communication of Barcelona en Comú confluence on Twitter. Not only according to the number of tweets disseminated, but also in communication strategic terms. $\mathrm{BeC}$ guided the issues as we observed in the tweets and re-tweets of the other five parties. The references of the five parties to $\mathrm{BeC}$ in their tweets were also common. Also, this political party carries out the most effective communication in Twitter in relation to the rest of the parties of the electoral coalition. As we aforementioned, the parties disseminated a big amount of issues but the corresponding number of tweets for each issue is not a very high number. Twitter was mainly used as a call for public or media acts, as retransmission channel for public meetings or speeches at the urban area, election debates in the mass media. In the same way that recent researches warned of the use of Twitter for the diffusion of their proposals (López-Meri, Marcos-García \& Casero-Ripollés, 2017) or how the new parties were just as prolific on Twitter as the traditional ones (Gómez-Calderó). This was mainly related to directive speech acts (Searle 1976, Austin, 2003). To sum up, the main functions of Twitter as an electoral communication tool by the confluence were as a "notice board" and as a tool for live coverage. The results show that the main sort of digital participation (Lobera, 2010) 
was communication. In other words, the exchange of information. Although the citizens/users were the main political agent that participated. The replies which generated dialogue (López-García \& Valera, 2015) were not assertive, so the interaction was limited to positive or negative comments. In the same line, in the argumentative replies, the quality of these arguments was superficial. For all those reasons, we agree with Carratalá and Galán's (2016) affirmation that citizen platforms or new parties do not maintain the level of participation and interaction. That confirms the thesis of mass media logic because the most common kind of participation was communication, instead of deliberation or enquiry/decision-making. Political parties did not exploit the potential or communication possibilities of Twitter in this sense, and their strategies are based on an hybrid logic (Alonso-Muñoz et al., 2016; López-García, 2016). In conclusion, the use of Twitter by the confluence Barcelona en Comú is limited as one way communication with the exception of the politician and the members of the communication group.

The most outstanding result from the message is the construction or framing of the electoral issue. In this sense, Barcelona en Comú built itself as an "alternative", "the common people" against "the others". As well, the electoral victory was constructed as the recovery of the public institutions and spaces, because they were stolen by "the others". For that, we conclude that Barcelona en Comú used a populist style of communication (Jagers \& Walgrave, 2007; Taggart, 2000; Moffit \& Tormey, 2016). In this case of study, the parties situated themselves in the left, so left-right dichotomy that according to Laclau (2005) populism denies is not clear in this case study. By contrast, we found simple and direct solutions based on the struggle between the elites and the people, the crisis or breakdown and the "others" (Moffit $\&$ Tormey, 2016). In line with the negative campaign (Auter \& Fine, 2016; Gross \& Johnson, 2016) the opposition parties were identified emphatically with a negative frame. This frame was based on corruption, cowardice, privatization, with "revolving doors" -the direct relation from politicians to companies- and humans' rights attack. The opposition parties were presented as the cause of social inequalities, which are a structural problem in Barcelona, and a priority of Barcelona en Comú. However, this negative campaign is more obvious and direct in the politicians' accounts.

Social media could be a channel to play the democratic struggle or the articulation of the hegemony (Laclau \& Mouffe, 2001; Laclau, 2005). However, it has been observed that the mass media logic is represented in their electoral communication (Bennet \& Iyengar, 2008; Chadwick, 2013; Vaccari, 2013; Couldry \& Hepp, 2017). In this regard, two kinds of strategies were differen- 
tiated. On one hand, the parties used Twitter to disseminate their content but they didn't use it as a bidirectional communication or a co-participation channel (Martínez, 2005; Aragón et al., 2013; Carpentier, 2015; Zugasti \& Sabés, 2015). Except in very few cases, the parties did not answer the users' interventions, ignoring that the more parties and politicians interact through networks, the more part of a community users/citizens feel (Jivkova-Simova, Requeijo-Rey \& Padilla-Castillo, 2017). On the other hand, we observed a second group formed by the politicians and people who took part in communication group that answered the users. This second group used Twitter as a bidirectional tool of communication so, accordingly to Aragón et al. (2015), Barcelona en Comú had two groups of actors on Twitter. One controlled by the party and other controlled by activists.

Although this study provides key features of the communication strategies and our objectives defined were responded, we consider that future research is necessary to complete the study of Barcelona en Comú electoral campaign. The analysis of this political coalition raises many questions that should be deepening in further research. The bidirectional process of communication took place among users, such as @3eses and citizens. Nevertheless, the communication commission members did not explicitly identify itself as members of the confluence. That suggests that the role played by these actors during the electoral campaign was as "citizens". The not so much coordinated communication strategy among the six political parties, with different Twitter accounts; makes us wonder what the internal organization of communication groups was. For all of this, we are aware that further research should consider semi-structured interviews with the community managers of the six parties.

\section{REFERENCES}

Aalberg, T., Esser, F., Reinemann, C., Strömbäck, J. \& De Vreese, C. (2017). Populist Political Communication in Europe. London: Routledge. ISBN: 9781315623016

Alarcón, M. A. (2008). "Austin y Searle: la relación entre verbos y actos ilocutorios". Literatura y lingüística, 19, 235-250.

Alonso, S. \& Rovira, C. (2014). "Spain: No Country for the Populist Radical Right?". South European Society and Politics, 20(1), 21-45.

DOI: $10.1080 / 13608746.2014 .985448$

Alonso-Muñoz, L., \& Casero-Ripollés, A. (2016). "La influencia del discurso sobre cambio social en la agenda de los medios. El caso de la Plataforma de Afectados por la Hipoteca". OBETS. Revista de Ciencias Sociales, 11(1), 25-51.

DOI: 10.14198/OBETS2016.11.1.02

Alonso-Muñoz, L., Marcos-García, S. \& Casero Ripollés, A. (2016). "Political Leaders in (inter)Action. Twitter As a Strategic Communication Tool in Electoral Campaigns". Tripodos, 39, 71-90. ISSN: 1138-3305 
Aragón, P., Kappler, K. E., Kaltenbrunner, A., Laviado, D. \& Volkovich, Y. (2013). "Communication Dynamics in Twitter During Political Campaigns: The Case of the 2011 Spanish National Election”, Policy and Internet, 5(2), 183-206.

https://doi.org/10.1002/1944-2866.poi327

Aragón, P., Volkovich, Y., Laviado, D. \& Kaltenbrunner, A. (2015). "When a Movement

Becomes a Party: The 2015 Barcelona City Council Election”. Eurecat, Spain. Recovered from https://arxiv.org/abs/1507.08599

Auriemma, M., Esposito, E., Iadiciccio, E., Marrazzo, F., Polimene, A., Punziano, G. \& Sarnelli, C. (2015). "Euroscetticismo a 5 Stelle: Stili comunicativi e online text data nel caso delle elezioni europee 2014". Sociologia della comunicazione, 49, 3654. http://dx.doi.org/10.3280/SC2015-049004

Austin, J. L. (2003). Cómo hacer cosas con palabras. Barcelona: Paidós. ISBN:9789501 267228

Auter, J. Z. \& Fine, J. A. (2016). "Negative Campaigning in the Social Media Age: Attack Advertising on Facebook". Political Behaviour, 38(4), 999-1020. doi:10.1007/s11109-016-9346-8

Bardin, L. (2002). Análisis de contenido. Madrid: Akal. ISBN: 978-84-7600-093-9

Benford, R. D. \& Snow, D. A. (2000). "Framing Processes and Social Movements: An Overview and Assessment". Annual Review of Sociology, 26, 611-639. https://doi.org/10.1146/annurev.soc.26.1.611

Bennett, L. W. \& Iyengar, S. (2008). "A New Era of Minimal Effects? The Changing Foundations of Political Communication". Journal of Communication, 58, 707-731. https://doi.org/10.1111/j.1460-2466.2008.00410.x

Block, E. \& Negrine, R. (2017). "The Populist Communication Style: Toward a Critical Framework". International Journal of Communication, 11, 178-197.

Bor, S. E. (2014). "Using social network sites to improve communication between political campaigns and citizens in the 2012 election". American Behavioural Scientist, 58(9), 1195-1213. https://doi.org/10.1177/0002764213490698

Borge, R. \& Santamarina, E. (2015). From protest to political parties: online deliberation in the new parties in arising in Spain. Paper prepared for the international conference: Democracy: A Citizen Perspective. Panel II: Political participation through social media. Chair: Rachel Gibson. Åbo Akademi University. Center of Excellence in Democracy Research (D:CE). Turku, Finland. May 27-28, 2015. Turku: Åbo Akademi University.

Borge, R. \& Esteve, M. (2017). "Organization Still Matters: Parties' Characteristics, Posting and Followers' Reactions on Facebook". International Journal of E-Politics, 8(1), 30-49.

Bosi, L., Giugni, M., \& Uba, K. (2016). "The consequences of social movements: taking stock and looking forward”. In L. Bosi, M. Giugni and K. Uba (Eds.), The consequences of social movements United Kingdom: Cambridge University Press, 3-37. ISBN: 978-1-107-53921-1 
Calvo, K., Gómez-Pastrana, T. \& Mena, L. (2011). "Movimiento 15M: ¿Quiénes son y que reivindican?". In: Especial 15-M Report. Recovered from http://www.fundacionalternativas.org/laboratorio/documentos/zoom-politico/especial-15-m

Campos-Domínguez, E. (2017). "Twitter y la comunicación política”, El Profesional de la Información, 26(5), 785-793.

Campos-Domínguez, E. \& Calvo, D. (2017). "La campaña electoral en Internet: planificación, repercusión y viralización en Twitter durante las elecciones municipales de 2015". Comunicación y Sociedad, 29, 93-116. ISSN-e 0188-252X

Carballo-Cruz, F. (2011). "Causes and Consequences of Spanish Economic Crisis: Why the Recovery is Taken so Long?". Panoeconomicus, 3, 309-328.

Carpentier, N. (2015). "Differentiating between access, interaction and participation". Conjunctions. Transdisciplinary Journal of Cultural Participation, 2(2), 7-28.

https://doi.org/10.7146/tjcp.v2i2.22915

Carratalá, A. \& Galán, M. (2016). "Estrategias comunicativas en Twitter de los ayuntamientos españoles gobernados por plataformas ciudadanas”. Revista Far@, 2(24), 126-150. e-ISSN 0718-4018

Casero-Ripollés, A., Feenstra, R. A., \& Tormey, S. (2016). "Old and New Media Logics in an Electoral Campaign: The Case of Podemos and the Two-Way Street Mediatization of Politics". The International Journal of Press/Politics, 21(3), 378-397. https://doi.org/10.1177/1940161216645340

Casero-Ripollés, A., Sintes-Olivella, M. \& Franch, P. (2017). "The Populist Political Communication Style in Action: Podemos' Issues and Functions on Twitter During the 2016 Spanish General Election". American Behavioral Scientist, 0(0), 1-16. https://doi.org/10.1177/0002764217707624

Castells, M. (2012). Redes de indignación y esperanza. Los movimientos sociales en la era de Internet. Madrid: Alianza Editorial. ISBN: 978-84-206-0960-7

Chadwick, A. (2013). The Hybrid Media System. Politics and Power. New York: Oxford University Press. ISBN: 978-0-19-975948-4

Colle, R. (2011). "El análisis de contenido de las comunicaciones". Cuadernos Artesanos de Latina, 11, La Laguna, Tenerife.

Couldry, N. \& Heep, A. (2013). "Conceptualizing Mediatization: Context, Traditions, Arguments". Communication Theory, 23(3), 191-202. DOI: 10.1111/comt.12019

Couldry, N. (2015). "The myth of 'us': digital networks, political change and the production of collectivity". Information, Communication E Society, 18(6), 608-626. https://doi.org/10.1080/1369118x.2014.979216

Couldry, N. \& Hepp, A. (2017). The Mediated Construction of Reality. Cambridge: Polity Press. ISBN: 978-0-7456-8130-6

della Porta, D. \& Mattoni, A. (2014). "Patterns of Diffusion and the Transnational Dimension of Protest in the Movements of the Crisis: An Introduction”. In D. Della Porta \& A. Mattoni (Eds.), Spreading Protest. Social Movements in Times of Crisis. United Kingdom: ecpr Press, 1-18. ISBN: 978-1910259207 
della Porta, D., Fernández, J., Kouki, H. \& Mosca, L. (2017). Movement Parties Against Austerity. Cambridge: Polity Press.

Edwards, G. \& Crossley, N. (2009). "Measures and Meanings: Exploring the Ego-Net of Helen Krikpatrick Watts, Militant Suffragette". Methodological Innovations Online, 4, 37-61. ISBN 1748-0612online

Edwards, G. (2010). "Mixed-Method Approaches to Social Network Analysis. ESRC National Centre for Research Methods". ESRC. Research National Center for Research Methods.

Entman, R. M. (1993). "Framing: Toward clarification of a fractured paradigm". Journal of Communication, 43(4), 51-58. https://doi.org/10.1111/j.1460-2466.1993.tb01304.x

Entman, R. M. (2004). Projections of Power: Framing News, Public Opinion, and U. S. Foreign Policy. Chicago: University of Chicago Press. ISBN: 9780226210728

Fenton, N. \& Barassi, V. (2011). "Alternative Media and Social Networking Sites: The Politics of Individuation and Political Participation". The Communication Review, 14(3), 179-196. https://doi.org/10.1080/10714421.2011.597245

Fernández-Planells, A., Figueras-Maz, M. \& Feixa, C. (2014). "Communication among Young people in the \#spanishrevolution: Uses of online-offline tools to obtain information about the \#acampadabcn". New Media E Society, 16(8), 1287-1308. DOI: $10.1177 / 1461444814530097$

Flesher, C. \& Montañés, A. (2014). "Transnational Diffusion Across Time: The Adoption of the Argentinian Dirty War 'Escrache' in the Context of Spain's Housing Crisis". In: D. della Porta, Donatella \& A. Mattoni (Eds.), Spreading Protest. Social Movements in Times of Crisis. United Kingdom: ecpr Press, 19-41.

ISBN: 9781910259207

Freelon, D. G. (2010). "Analyzing online political discussion using three models of democratic communication". New Media E Society, 12(7), 1172-1190. https://doi.org/10.1177/1461444809357927

Freeman, L. C. (1979). "Centrality in Social Networks. Conceptual Clarification". Social Networks, 1, 215-239.

García-Carretero, L. \&Pérez- Altable, L. (2017). "Barcelona en Comú on Twitter. Analysing the electoral communication of the confluence during the 2015 council election". El Profesional de la Información, 26(5), 872-884 ISSN: 1699-2407

Gerbaudo, P. \& Screti, F. (2017). "Reclaiming Popular Sovereignty: The Vision of the State in the Discourse of Podemos and Movimento 5 Stelle". Javnost-The Public, 24(4), 320-335. http://dx.doi.org/10.1080/13183222.2017.1330089

Germani, G. (2003). Autoritarismo, fascismo y populismo nacional. Buenos Aires: Temas. ISBN: 9789879164884

Gitlin, T. (1980). The Whole World is Watching. Berkeley: University of California Press. ISBN: 9780520239326

Goffman, E. (1986). Frame Analysis. An Essay on the Organization of Experience. Boston: Northeastern University Press. ISBN: 0-930350-91-X 
Gómez-Calderón, B., Roses, S. \& Paniagua-Rojano, J. (2017). "La campaña en 140 caracteres. Empleo de Twitter por parte de los candidatos mayoritarios ante las elecciones generals de 2016 en España”. El Profesional de la Información, 26(5).

Graham, T., Broersma, M., Hazelhoff, K. \& G. van't Haar (2013). "Between Broadcasting Political Messages and Interacting with voters: The Use of Twitter during 2010 UK General Election". Information, Communication and Society, 16(5), 692716.

Gramsci, A. (2009). De la política al Estado moderno. Madrid: Biblioteca de Pensamiento Crítico. ISBN: 8437008877778

Gross, J. H. \& Johnson, K. T. (2016). "Twitter Taunts and Tirades: Negative Campaigning in the Age of Trump". Political Science E Politics, 49(4), 748-754. doi:10.1017/S1049096516001700

Holba, A. M. (2010). Political Communication and Leisure. The Review of Communication, 10(1), 20- 37. https://doi.org/10.1080/15358590903248736

Jagers, J. \& Walgrave, S. (2007). "Populism as Political Communication Style: An Empirical Study of Political Parties' Discourse in Belgium". European Journal of Political Research, 46(3), 319-45. DOI: 10.1111/j.1475-6765.2006.00690.x

Jivkova-Semova, D.; Requeijo-Rey, P. \& Padilla-Castrillo, G. (2017). "Usos y tendencias de Twitter en la campaña a las elecciones generals españolas del 20D de 2015: hashtags que fueron trending topic". El Profesional de la Información, 26(5), 824-837.

Jungherr, A. (2015). "Twitter use in election campaigns: Systematic literature review. Journal of Information Technology \& Politics", 13(1), 72-91.

DOI: $10.1080 / 19331681.2015 .1132401$

Krippendorff, K. (2013). Content Analysis. An introduction to its methodology. Los Ángeles: SAGE Publications. ISBN: 978-1-4129-8315-0

Laclau, E.\& Mouffe, C. (2001). Hegemony and Socialist Strategy. Towards a Radical Democracy Politics. London: Verso. ISBN: 1-85984-330-1

Laclau, E. (2005). On populist reason. London: Verso. ISBN: 9781859846513

Lakoff, G. (2004). Don't Think of an Elephant!: Know your Values and Frame the Debate. Canada: Chelsea Green Publishing Company. ISBN: 1-931498-71-7

Landerer, N. (2013). "Rethinking the Logics: A Conceptual Framework for the Mediatization of Politics". Communication Theory, 23(3), 239-258.

DOI: $10.1111 /$ comt. 12013

Likki, T. (2012). "15M Revisited: a diverse movement united for change". Zoom Politico. Recovered from: http://www.falternativas.org/laboratorio/libros-einformes/zoom-politico/15m-revisited-a-diverse-movement-united-for-change

Lilleker, D. G., Koc-Michalska, K. \& Schweitzer, E. J. (2011). "Informing, engaging, mobilizing or interacting: Searching for a European model of web campaigning". European Journal of Communication, 26(3), 195-213.

Linares-Lanzman, J. \& Pérez-Altable, L. (2015). Usos de Twitter durante el 15-M. El caso de la prensa catalana. Dur le Journalism, 4(1), 67-75.

Linares Lanzman, Juan (2017). El 15M y los medios españoles. Análisis de redes temáticas en Twitter. (PhD Dissertation) Universitat Pompeu Fabra, Barcelona. 
Lobera, J. (2010). Sostenibilitat, participació i educació: les concepcions del món i de la tecnociència en la transformació dels conflictes socioambientals (PhD Dissertation). Universidad Politécnica de Catalunya, Barcelona.

Lobera, J. (2015). "De movimientos a partidos. La cristalización electoral de la protesta". RES, 24, pp. 97-105. ISSN: 1578-2824

López-García, G. \& Valera-Ordaz, L. (2015). "El estudio de los flujos de comunicación en procesos de comunicación política: una aproximación metodológica". Recovered from https://www.academia.edu/18288900/El_estudio_de_los_flujos_de_comu nicaci\%C3\%B3n_en_procesos_de_comunicaci\%C3\%B3n_pol\%C3\%ADtica_una_ aproximaci\%C3\%B3n_metodol\%C3\%B3gica

López-García, G. (2016). 'New' vs 'old' leadership: the campaign of Spanish general elections 2015 on Twitter. Communication \& Society, 29(3), 149-168.

https://doi.org/10.15581/003.29.3.149-168

López-García, G., Cano, L. \& Argilés, L. (2016). "Circulación de los mensajes y establecimiento de la agenda en Twitter: el caso de las elecciones autonómicas de 2015 en la Comunidad Valenciana”. Trípodos, 39, 163-183. ISSN: 1138-3305

López-García, G. (2017). "Comunicación política y discursos sobre el poder". El Profesional de la Información, 26(4), 573-578. eISSN: 1699-2407

López-Meri, A., Marcos-García, S. \& Casero-Ripollés, A. (2017). "What politicians do on Twitter? Functions and communication strategies in the Spanish electoral campaign of 2016". El Profesional de la Información, 26(5), pp. 795-804.

Maarek, P. J. (1997). Marketing político y comunicación. Claves para una buena información política. Barcelona: Paidós. ISBN: 9788449304514

Marcos-García, S., Alonso-Muñoz. L. \& Casero Ripollés, A. (2017). "Usos ciudadanos de Twitter en eventos políticos relevantes. La \#SesiónDeInvestidura de Pedro Sánchez". Comunicación y Hombre, 13, 25-49.

Marín, P. P. \& Díaz, A. (2016). "Uso de Twitter por los partidos y candidatos políticos en las elecciones autonómicas de Madrid 2015". Ámbitos: Revista Internacional de Comunicación, 32, 1-16.

Martínez, L. (2005). "La participación de los usuarios en los contenidos periodísticos en la Red". In: G. López-García (Ed.), El ecosistema digital: modelos de comunicación, nuevos medios y público en Internet. Valencia: Universitat. ISBN 84-370-6302-7

Mattoni, A. \& Treré, E. (2014). "Media Practices, Mediation Processes, and Mediatization in the Study of Social Movements". Communication Theory, 24, 252-271. https://doi.org/10.1111/comt.12038

Mazzoleni, G. (2008). "Mediatization of Politics". In: W. Donsbach (Ed), The International Encyclopedia of Communication. Malden, MA: Blackwell, 3017-305.

Mazzoleni, G. (2017). "Changes in Contemporary Communication Ecosystems Ask For A "New Look" At The Concept of Mediatisation". Javnost-The Public, 1-10. Recovered from http://dx.doi.org/10.1080/13183222.2017.1290743

McAdam, D. \& Tarrow, S. (2010). "Ballots and barricades: On the reciprocal relationship between elections and social movements". Perspectives on Politics, 8(2), 529542. http://dx.doi.org/10.1017/S1537592710001234 
McNair, B. (2006). Cultural Chaos: Journalism and Power in a Globalised World. London: Routledge. ISBN-10: 0415339138

Moffitt, B. \& Tormey, S. (2014). "Rethinking Populism: Politics, Mediatisation and Political Style". Political Studies, 62, 381-397. DOI: 10.1111/1467-9248.12032

Morales-Guzmán, A. J., Borondo-Benito, J. \& Benito, R. M. (2014). "Efficiency and human activity of information spreading on Twitter". Social Networks, 39, 1-11 https://doi.org/10.1016/j.socnet.2014.03.007

Mosca, L. (2014). "The Five Star Movement: Exception or Vanguard in Europe? The International Spectator”. Italian Journal of International Affairs, 49(1), 36-52. http://dx.doi.org/10.1080/03932729.2013.875821

Nielsen, S. W. (2012). "Three faces of political marketing strategy". Journal of Public Affairs, 12(4), 293-302.

Orriols, L. \& Cordero, G. (2016). "The Breakdown of the Spanish Two-Party System: The Upsurge of Podemos and Ciudadanos in the 2015 General Election". South European Society and Politics, 21(4), 469-492.

http://dx.doi.org/10.1080/13608746.2016.1198454

Pérez, M. \& Nicasio, B. (2015). "Campañas 2.0 en la Comunidad Valenciana: las primarias en Coalició Compromís y Ciudadanos como estudio de caso". Ámbitos: Revista Internacional de Comunicación, 29.

Piccio, D. R. (2016). "The impact of social movements on political parties". In L. Bosi, M. Giugni, and K. Uba (Eds.), The consequences of social movements. United Kingdom: Cambridge University Press, 263-284. ISBN: 978-1-107-53921-

Poulakidakos, S. \& Veneti, A. (2016). "Political Communication and Twitter in Greece: Jumps on the Bandwagon or an Enhancement of the Political Dialogue?" In: Dezelan, Tomaz; Vobic, Igor (Eds.), (R)evolutionizing Political Communication through Social Media. USA: IGI Global, pp. 119-146.

Quevedo, R., Portalés-Oliva, M \& Berrocal, S. (2016). "El uso de Twitter durante la campaña electoral municipal de 2015 en España”. Revista Latina de Comunicación Social, 71, 85-107. DOI: 10.4185/RLCS-2016-1085

Rooduijn, M. (2014). "The Mesmerising Message: The Diffusion of Populism in Public Debates in Western European Media”. Political Studies, 62, 726-744.

DOI: $10.1111 / 1467-9248.12074$

Roos, J. \& Oikonomakis, L. (2014). "They don't represent us! The Global Resonance of the Real Democracy Movement from the Indignados Occupy". In D. Della Port \& A. Mattoni (Eds.), Spreading Protest. Social Movements in Times of Crisis. United Kingdom: ecpr Press, 117-136. ISBN: 978-1910259207

Royo, S. (2014). "Institutional Degeneration and the Economic Crisis in Spain". American Behavioral Scientist, 58(12), 1568-1591.

http://dx.doi.org/10.1177/0002764214534664

Sampedro, V. (Coord.) (2011). Cibercampaña. Cauces y diques para la participación. Las Elecciones Generales de 2008 y su proyección tecnopolítica. Madrid: Complutense. ISBN: 978-84-9938-094-0 
Sampedro, V., \& Sánchez-Duarte, J. M. (2011). "15-M: La Red era la plaza". In V. Sampedro (Coord.), Cibercampaña. Cauces y diques para la participación. Madrid: Complutense, 237-242. ISBN: 978-84-9938-094-0

Sampedro, V., Sánchez-Duarte, J. M., \& Campos, E. (2014). "Participación ciudadana en las cibercampañas electorales. Debates teóricos y una aproximación tipológica". In R, Cotarelo y J. A. Olmeda (Comps.), La democracia del siglo XXI. Política, medios de comunicación, internet y redes sociales. Madrid: Centro de Estudios Políticos y Constitucionales. ISBN: 978-84-259-1591-8

Sanz, J., \& Mateos, O. (2014). “¿No es país para jóvenes? Juventud, indignación y cambio social en el contexto post-15-M". Iglesia Viva, 258, 29-52.

Searle, J. R. (1976). "Una taxonomía de los actos ilocucionarios". Teorema: revista internacional de filosofía, 6(1), 43-78.

Strömbäck, J. (2008). "Four phases of mediatization: An analysis of the mediatization of politics". The International Journal of Press/Politicas, 13(3), 228-246.

https://doi.org/10.1177/1940161208319097

Taggart, P. (2000). Populism. Birmingham: Open University Press.

Tromble, R. (2016). "Thanks for (actually) responding! How citizen demands shapes politicians' interactive preactices on Twitter". New Media E Society, 23, 1-22. https://doi.org/10.1177/1461444816669158

Vaccari, C. (2013). Digital Politics in Western Democracies. A Comparative Study. Baltimore: The Johns Hopkins University Press.

Van Gorp, B. (2010). "Strategies to Take Subjectivity Out of Framing Analysis". In P. D'Angelo and J. A. Kuypers (Ed.), Doing News Framing Analysis. Empirical and Theoretical Perspectives. New York: Routledge, 84-109. ISBN: 0415992362

Yin, R. K. (2009). Case Study Research: Design and Methods. London: Sage.

Zugasti, R. \& Sabés, F. (2015). "Los issues de los candidatos en Twitter durante la campaña de las elecciones generales de 2011". Zer, 20(38), 161-178. 


\section{BREVES NOTAS BIOGRÁFICAS}

LUCÍA GARCÍA-CARRETERO: Degree in Journalism from Universidad de Valladolid and master in Social Communication at Universitat Pompeu Fabra. A predoctoral researcher at the Communication Department at Pompeu Fabra University. Her main lines of research are political communication and digital journalism.

https://orcid.org/0000-0002-1414-3921

JAVIER DÍAZ-NOCI: Full professor at Communication Department at Pompeu Fabra University in Barcelona. PhD in Journalism and PhD in Law. His main research interests are online journalism and online news, history of journalism and copyright and news reporting.

http://orcid.org/0000-0001-9559-4283

Recibido: 07-11-2017

Aceptado: 23-11-2018

(C) (7) Licencia Creative Commons Reconocimiento (CC BY 4.0) 



\title{
LA PARTICIPACIÓN SOCIAL ONLINE Y OFFLINE DE ESTUDIANTES UNIVERSITARIOS ESPAÑOLES ${ }^{1}$ ONLINE AND OFFLINE SOCIAL PARTICIPATION OF SPANISH GRADUATE STUDENTS
}

\author{
Izarne Lizaso Elgarresta \\ Universidad del País Vasco/Euskal Herriko \\ Unibertsitatea (UPV/EHU), España \\ izarne.lizaso@ehu.eus \\ Inmaculada Sánchez-Queija \\ Universidad de Sevilla (US), España \\ queija@us.es \\ Agueda Parra Jiménez \\ Universidad de Sevilla (US), España \\ aparra@us.es \\ Enrique Arranz Freijo \\ Universidad del País Vasco/Euskal Herriko \\ Unibertsitatea (UPV/EHU), España \\ e.arranzfreijo@ehu.es
}

Cómo citar / citation

Lizaso, I., Sánchez-Queija, I., Parra, A. y Arranz, E. (2018) "La participación social online y offline de estudiantes universitarios españoles". OBETS. Revista de Ciencias Sociales, 13(2): 547-567.

doi: 10.14198/OBETS2018.13.2.04

${ }^{1}$ El presente artículo ha sido posible gracias a financiación del Ministerio de Economía y Competitividad del Gobierno de España (Referencia: EDU2013-45687-R).

Correspondencia: Inmaculada Sánchez Queija, Dpto. Psicología Evolutiva y de la Educación, Universidad de Sevilla, Facultad de Ciencias de la Educación. c/ Pirotecnia, s/n, 41013 Sevilla (España). E-mail: queija@us.es 


\title{
Resumen
}

El objetivo fundamental del trabajo es conocer si la participación social online favorece la participación social offline de los jóvenes universitarios. 1502 estudiantes universitarios respondieron la encuesta latinoamericana de participación cívica, a la que se añadieron ítems de participación online. Los resultados mostraron que los jóvenes más activos en la vida online respecto a una temática lo son también en la vida offline en esa misma temática. Se discute que el mundo online es una ampliación del offline tan real como este último. Potenciar la participación online redundará en la mejora social y en la tarea de convertirse en ciudadano.

Palabras clave: participación social, redes sociales, contexto universitario, comunicación digital, internet, interacción/interactividad, sexo, educación superior.

\begin{abstract}
The main aim of this paper is to check if offline social participation is fostered by online undergraduates social participation. 1502 undergraduate students are fulfilled Latin American social participation questionnaire. Two new specific items were added to evaluate the online social participation. Result showed the most networking active graduates are the most active ones in face to face on the very same topic. The online world is an extension as real as the offline. The enhancement of the online social participation will promote both social improvement, and the achievement of civic responsibility as an individual developmental task.
\end{abstract}

Keywords: Social Participation, social networks, university context, digital communication, internet, interaction, sex, high education.

\section{Extended abstract}

Social participation refers to individual and collective actions aimed at identifying and dealing with questions of public interest. The social media foster interactions between people and are characterized by their immediacy. They can therefore help individuals participate more actively in society. Indeed, over recent years, the social media have become one of the fastest and most accessible means of online social participation.

The main aim of this paper was to determine whether online social participation fosters offline social participation among university undergraduate students. The study was based on the gateway hypothesis, according to which, activation through the more immediate and accessible social media promotes offline participation among citizens. Undergraduate students have traditionally been considered very active at a social level, which is why we also decided to analyze whether or not the knowledge area of their chosen subject fostered their active social participation. Gender differences were also explored in relation to students' online participation.

A traditional, offline survey was administered to a sample of 1502 undergraduate students $(39.9 \%$ men, mean age $=20.32)$ from two Spanish universities. The sample was representative of the different areas of knowledge. Participants 
completed the Latin American civic participation questionnaire (Adúriz \& Ava, 2006), to which two items were added on online social participation. The results revealed that the most frequent type of participation among undergraduate students consists of completing surveys or opinion polls (74\%), followed by making political demands through the social media (63.3\%), online support for political events (46\%) and participation in sports associations (30\%) and protest marches (27\%).

As regards area of knowledge, students studying health sciences were particularly active as regards making political demands through the social media; however, they were also those who supported political events through the social media least frequently. Arts and humanities students were the group with the highest level of online support for political events. In terms of gender, women made more political demands through the social media, although no gender differences were observed in relation to online support for political events. As regards the gateway hypothesis, a relationship was observed between making demands on the social media and participating in NGOs, being a member of a political party or completing surveys or opinion polls. However, no association was observed between making demands online and other types of offline participation. For their part, those who most supported political events online were also those who participated more in political parties, protest marches and surveys and opinion polls; they were also those who were most likely to contact the government. Online support for political events was not found to be associated with any of the other types of offline participation. The results of this study indicate that the social media are used for something more than simple entertainment or for expanding one's personal social network: they are also used to engage with civic, social or political issues. Thus, the social media are a place for learning, exchange and awareness-raising in relation to how to deal with and regulate issues of public interest.

The undergraduate students in the sample group were not found to participate more than their non-university counterparts. Nor indeed was the subject of their university studies, represented in terms of knowledge areas, observed to have any clear relationship with a greater or lesser degree of participation. This was particularly evident in the case of those studying the health sciences, who were the most participatory in terms of making demands over the social media, yet the least participatory in terms of supporting political events. Nevertheless, arts and humanities students were found to be more supportive of political events, thus opening up a new avenue of research which requires more in-depth study in the future.

Consistently with the greater level of participation observed among women in community-oriented issues, such as efforts to improve society or helping those in need, female undergraduates were observed to make more political demands through the social media than their male counterparts. This may be due to the fact that most political demands made online are related to this kind of social improvement or helping those in need. Nevertheless, no gender differences were observed in relation to participation in political events, which may reflect a closing of the gender gap in this sense. 
Finally, the gateway hypothesis was not supported by the findings of this study, which moreover revealed that socially-active people are not active in relation to any issue and through all formats. Rather, their participation varies in accordance with content. Thus, those who support political events online are more likely to contact the government, participate in political events offline and go to protest marches; in other words, they participate in political issues both online and offline, but do not participate in other aspects of civil life, such as sports associations, religious organizations or NGOs. The findings support the idea that the online environment is really no different from other forms of social participation, but rather merely expands the traditional circuits for gathering, socialization and participation to a new context, namely the online world. It is therefore important to question whether we should continue to make a distinction between the offline and online worlds, viewing them as if they were completely different universes. The results of this study support the idea that both environments are equally real, and moreover, are interdependent. Online demands have a repercussion on people's daily offline lives. Similarly, online support for political events may result in real decisions made by elected officials, thus affecting the whole population.

Shouldering one's civic responsibilities is one of the developmental tasks pertaining to young adulthood. Social engagement and participation (both online and offline) not only help improve the society in which young people live, they also contribute to enhancing their own personal wellbeing. Given the importance of the social media in 21 st century society, it is logical to assume that an increasing proportion of young people's social participation will take place in these virtual environments. It is a type of social participation that will hopefully give rise to a new e-generation of more critical citizens, resulting in empowerment through education and social and political movements capable of steering society towards greater levels of social equality and balance.

\section{INTRODUCCIÓN}

En los últimos años el uso de Internet se ha generalizado, especialmente en personas jóvenes menores de 30 años y por medio de los teléfonos móviles como dispositivos de última generación (Pew Research Center, 2012). Según ese mismo estudio, desde 2009 cerca del 93\% de los adolescentes utiliza Internet, el $60 \%$ de ellos se conecta para obtener noticias e información sobre eventos de actualidad o política, y más del 70\% usa una red social en Internet. En España, en el mismo año 2012, según el INE, el 88,5\% de los jóvenes entre 16 y 24 años utilizaba las redes sociales, ascendiendo este porcentaje al 90\% de los adolescentes entre 14 y 18 años en 2013 (García, López de Ayala y Catalina, 2013) y al 96,64\% de los estudiantes universitarios en 2015 (Sánchez-Rodríguez, RuizPalmero y Sánchez-Rivas, 2015).

Las redes sociales son una estructura que contiene un servicio, basado en Internet, que permite a las personas construir un perfil público o semipúbli- 
co dentro de un sistema delimitado, manejar una lista de usuarios con los que compartir una conexión, ver y explorar su lista de conexiones y aquellas realizadas por otros usuarios dentro del sistema (Boyd y Ellison, 2007). A diferencia de otros medios de comunicación, como por ejemplo la televisión, las redes sociales se caracterizan por la inmediatez y la interactividad (García-Galera, Del-Hoyo y Fernández, 2014); es decir, tienen la capacidad de favorecer la interacción entre personas, por lo que pueden ayudar a su integración y participación en la vida social activa.

Un tipo de participación que crece en este entorno virtual es la participación social, que se ha definido como "las acciones individuales y colectivas destinadas a identificar y abordar cuestiones de interés público" (American Psychological Association, 2014, p.58). Así, la persona socialmente participativa se describe "como un ciudadano activo que participa en la vida de una comunidad con el fin de mejorar las condiciones para los demás o para ayudar a formar el futuro de la comunidad" (Adler y Goggin, 2005, p. 241). En ese sentido, la participación social hace referencia a la participación del ciudadano en la agenda pública, y no sólo en los asuntos del estado, sino además en otros aspectos de interés público como puedan ser las ONG y otros ámbitos de la sociedad civil (Adúriz y Ava, 2006). Una participación que puede realizarse en entornos institucionalizados o no (Ganuza y Francés, 2015).

Una de las formas más accesibles y rápidas para la participación social es a través de Internet (Amna, Ekstrom, Kerr y Stattin, 2009; Jacobson y Culver, 2012), principalmente a través de las redes sociales (Facebook, Twitter, blogs...). Los jóvenes usan estas redes para organizar actividades, discutir, compartir información, participar y expresar su descontento (González, Becerra y Berenice, 2016). En ocasiones, la persona decide dar un paso más allá de ese intercambio de mensajes en la red social de turno para trasladar su defensa de los valores al mundo offline (García-Galera, et ál., 2014). En esos casos, la denominada participación directa o presencial se da cara a cara en el espacio físico y consiste en la participación en manifestaciones, sindicatos, organizaciones de la comunidad, etc. (Winocur, 2006).

Al igual que la investigación ha mostrado que la mayoría de las redes sociales sirven para reforzar relaciones sociales existentes (Subrahmanyam, Reich et al., 2008), algunos autores apuntan que los jóvenes que participan en redes sociales son más políticamente activos también en el mundo real (Zhou y Pinkleton, 2012). Sería la hipótesis del Gateway, según la cual la activación a través de internet desencadenaría la participación directa de los ciudadanos. Por el contrario, otros afirman que las personas utilizan las redes sociales principalmente con fines informativos y expresivos y que los jóvenes utilizan internet 
para obtener información relacionada con las protestas, pero esta actividad no afecta a su comportamiento offline (Macafee y De Simone, 2012). Desde esta perspectiva, internet/redes sociales son un contexto diferenciado del mundo offline y el comportamiento de las personas sería diferente en uno y otro espacio.

Esta dicotomía (Gateway o no) se refleja en nuestro entorno más inmediato. Así, en un estudio reciente (García-Galera, et al, 2014) en el que han participado más de 1300 jóvenes españoles a través de la red social Tuenti, los resultados ponen de manifiesto que, aunque un $26 \%$ de los jóvenes está de acuerdo con la afirmación "las redes sociales me han llevado a desarrollar/participar en alguna acción de protesta social", más de un $44 \%$ reconoce que, aunque participa en eventos online, no se suma a ellos en la vida offline. En el trabajo que aquí se presenta, se aportarán datos para conocer si la hipótesis del Gateway se cumple en una muestra de estudiantes universitarios españoles que cumplimentaron la información de manera presencial, no virtual como en el estudio de García-Galera et al (2014).

Los jóvenes universitarios han sido, tradicionalmente, especialmente reivindicativos para la mejora de la sociedad, tal y como demuestran las movilizaciones de los indignados del 15-M del 2011 en España. En estas movilizaciones se protestaba en contra de un sistema que, especialmente según los más jóvenes, no brindaba oportunidades laborales por causa de una clase política desprestigiada y buscaba, a través de protestas pacíficas, mayor participación ciudadana (Ayala, 2014). Se han producido movilizaciones similares en Latinoamérica, como por ejemplo, las movilizaciones estudiantiles en Chile en pro de la democracia y contra la corrupción (Montes, 2015), en Colombia en contra de los procesos de mercantilización de la educación (Archila, 2012), las que se produjeron en 2013 y 2014 en Brasil (Ayala, 2014), o las movilizaciones estudiantiles Venezolanas en una relación de antagonismo con un gobierno de orientación anti-neoliberal (Uzcátegui 2014). Se suele argumentar que estos jóvenes poseen formación, capacidad para cuestionar el estatus-quo político o social y la juventud necesaria para querer cambiar ese estado de las cosas en pro de una mejor vida que comienzan a vivir.

Sin embargo, no conocemos ningún trabajo que analice empíricamente si los ámbitos específicos de conocimiento de la formación universitaria están relacionados con una mayor facilidad para la participación social. Así, en este trabajo se analizará la participación social online de jóvenes que estudian diferentes áreas de conocimiento, de manera que se podrá comparar si el tipo de disciplina que se estudia influye -o no- en la participación social online de los jóvenes. En este sentido, y de forma intuitiva, se parte de dos hipótesis. La primera, sugiere que los y las jóvenes que estudian humanidades serán más proclives 
a la participación social online al estar motivados para formarse y estar recibiendo formación relacionada con la cultura humana y cómo mejorarla. La segunda estaría más relacionada con el formato de participación. Así aquellos jóvenes que más se relacionan con las nuevas tecnologías y su aparataje tendrían más facilidad para participar online, por tanto habría más participación online del estudiantado de ingeniería y arquitectura.

Una cuestión que sí ha generado investigación son las diferencias de género tanto en el uso de las redes sociales como en la participación social. Respecto a las redes sociales, parece que las chicas utilizan las redes sociales tipo facebook más que los chicos (Thompson y Ches, 2012). Sin embargo, este mayor uso de ellas se realiza con fines comunicativos (Kimbrough, Guadagno, Muscanell y Dill, 2013), no de participación social. Respecto a la participación social offline de los jóvenes, el Eurobarómetro de la Comisión Europea de 2015 informa que los chicos participan más que las chicas en actividades relacionadas con los clubs deportivos, organizaciones para pasar el tiempo libre o cualquier otro tipo de organización juvenil, mientras que no aparecen diferencias de género en la participación social juvenil destinada a mejorar la comunidad a nivel local, en organizaciones culturales, organizaciones destinadas a mantener o promocionar los derechos humanos y el desarrollo global, relativas al cambio climático o no gubernamentales (UE, 2015).

El primer objetivo de este trabajo consistió en describir la participación social online (a través de plataformas y redes sociales) y offline de una muestra de estudiantes universitarios. Teniendo en cuenta que la participación online es menos costosa que la offline y que sin necesidad de esfuerzo, sentados delante de su ordenador aparecerán en la pantalla diferentes cuestiones de interés público que harán platearse al universitario hacer click o no para sumarse, compartir o discutir alguna de ellas, nuestra hipótesis fue que la participación online sería mayor que la offline (H1). En segundo lugar, este trabajo se planteó algo completamente novedoso en el estudio de la participación social a través de las redes sociales: si la rama de conocimiento que están estudiando los jóvenes influye en una mayor o menor participación online. En este sentido, se partió de dos hipótesis diferentes: los jóvenes que estudian humanidades serán más participativos (H2) o bien lo serán aquellos que están más habituados al uso de las nuevas tecnologías (H3). Un tercer objetivo fue conocer las diferencias en función del género de la participación social online. En este sentido, y teniendo en cuenta el tipo de preguntas que se plantean, relacionadas con la reivindicación vía red social y el apoyo a actos políticos en redes sociales, se esperó una participación similar de chicos y chicas (H4). 
Una vez descrita la participación online en función de la rama de conocimiento y el género de los participantes en el estudio abordamos el principal objetivo de esta investigación, probar si la aproximación a la participación social a través de las redes sociales se queda ahí o facilita una mayor implicación y participación social en la vida pública fuera del mundo virtual. Es decir, la hipótesis del Gateway o puerta de entrada en la participación social offline a raíz de la E-participación. Esperábamos encontrar que los jóvenes más activos, es decir, más participativos, lo serán en ambos contextos (H5).

\section{METODOLOGÍA}

La muestra estuvo compuesta por 1502 estudiantes universitarios de la Universidad de Sevilla y la Universidad del País Vasco/Euskal Herriko Unibertsitatea (39,9\% varones; Edad $M=20.32, D T=2.13$, Rango= 18-29). Según el Ministerio de Educación, Cultura y Deporte, en el curso escolar 2014/15 -momento de la recogida de datos- el 45,6\% de los estudiantes fueron varones (MECD, 2015), lo que justifica la menor proporción de chicos que de chicas en nuestra muestra. Respecto al nivel socioeconómico percibido de los participantes, un $15,8 \%$ informó tener un nivel bajo, un 70,1\% medio y un $14,1 \%$ se percibió con un nivel socioeconómico alto. Por otro lado, se intentó que la distribución de la muestra fuera representativa de las diferentes ramas de conocimiento. Así, la muestra se distribuyó de la siguiente forma (en primer lugar aparece el porcentaje muestral y en segundo lugar el porcentaje de estudiantes de esa rama de conocimiento según el MECD, 2015): Artes y humanidades (8,5\% y 9,5\% respectivamente), Ciencias Sociales y Jurídicas (32,2\% y 46,6\%), Ingeniería y Arquitectura (23,5\% y 20,2\%) y Ciencias de la Salud (29,2\%, $17,0 \%)$ y Ciencias (6,7\% y $5,7 \%)$. El análisis de aquiescencia eliminó a 11 participantes que habían contestado sí a una participación activa en todos los organismos y no en todos los ítems de participación opinativa. Así la muestra final estuvo compuesta por 1490 jóvenes adultos, es decir, un 99,27\% de la muestra inicial.

Los datos se recolectaron durante la primavera de 2015, en formato papel y en las aulas universitarias, de forma que la muestra no recoge a personas especialmente activas en las redes sociales, sino que es una muestra representativa de la población universitaria de las dos universidades implicadas. El procedimiento seguido en este estudio fue aprobado por el comité de ética de la investigación biomédica de la Junta de Andalucía. La participación fue voluntaria y anónima.

El instrumento de evaluación se basó en la encuesta latinoamericana sobre participación cívica (Adúriz y Ava, 2006). Esta encuesta ofrece un índice de participación directa offline $(\alpha=0,71)$ compuesto por 11 preguntas sobre si 
participa o no en diferentes organizaciones como sindicatos, asociaciones deportivas y estudiantiles (ver tabla 1). Las opciones de respuesta son 0 , no participo; 1, participo (denominado participación simple); 2 , tengo un cargo directivo, participo en reuniones, pago cuotas, realizo donaciones o participo en la toma de decisiones (denominado participación activa). La encuesta ofrece también un índice de participación opinativa ${ }^{2}$ sumando los cuatro ítems en los que se pregunta si se utiliza algún medio (ver tabla 2) para opinar sobre cuestiones sociales. Sin embargo, el alfa de cronbach obtenido en esta subescala $(\alpha=0,28)$ desaconseja su utilización en calidad de escala.

Para cubrir los objetivos de la presente investigación y obtener información de la participación social online se añadieron las preguntas: ¿Te uniste a alguna reivindicación solidaria vía Twitter, Facebook, Tuenty u otra red social?; ¿Apoyaste o reclamaste algún acto político en las redes sociales? Las opciones de respuesta fueron sí o no.

\section{RESULTADOS}

Para responder al primer objetivo, en la tabla 1 se presentan los porcentajes de respuesta obtenidos en el cuestionario de participación directa o participación offline. La última columna presenta la prevalencia de participación, que se obtiene con la suma de las columnas participación simple y activa.

La forma más frecuente de participación offline (tabla 1) es a través de asociaciones deportivas y manifestaciones, con una prevalencia de participación del $30,5 \%$ y $27,4 \%$ respectivamente. La participación más baja se encuentra en los sindicatos o colegios profesionales (3,9\%). Si se analizan los datos considerando cada tipo de participación, los datos indican una participación social muy baja. En un rango posible de 0 (no participación) a 18 (participación activa en cada modalidad) se obtiene una Media de participación de 1,91 y Desviación tipo de 2,55.

Respecto a la participación opinativa (tabla 2), los estudiantes universitarios entrevistados prefieren participar en encuestas o consultas, siendo la opinión en programas de Tv o el contacto directo con el gobierno las opciones menos utilizadas. En ningún momento se indicó que las consultas o encuestas tuvieran que ser offline por lo que las respuestas a este ítem pueden estar incluyendo participación online.

Finalmente, en las cuestiones específicamente relacionadas con la participación online a través de las redes sociales se encuentran las tasas de partici-

${ }^{2}$ Aunque el adjetivo opinativo no existe según la RAE, hemos decidido mantener el nombre original propuesto por los autores. 
Tabla 1. Porcentaje de respuestas de los encuestados a las preguntas relacionadas con la participación directa offline

\begin{tabular}{l|c|c|c|c}
\hline & $\begin{array}{c}\text { No } \\
\text { participación } \\
\%\end{array}$ & $\begin{array}{c}\text { Participación } \\
\text { Simple } \\
\%\end{array}$ & $\begin{array}{c}\text { Participación } \\
\text { Activa } \\
\%\end{array}$ & $\begin{array}{c}\text { Prevalencia } \\
\%\end{array}$ \\
\hline $\begin{array}{l}\text { Partidos y movimientos } \\
\text { políticos }\end{array}$ & 85,2 & 9,7 & 5,1 & 14,8 \\
\hline ONGs & 87,8 & 7,5 & 4,7 & 12,2 \\
\hline Organización religiosa & 88,3 & 6,5 & 5,2 & 11,7 \\
\hline Movimiento local & 82,4 & 11,5 & 6,1 & 17,6 \\
\hline Organización deportiva & 69,5 & 21,4 & 9,1 & 30,5 \\
\hline Redes solidarias & 86,9 & 9,3 & 3,9 & 13,2 \\
\hline Sindicato, colegio profesional & 96,1 & 2,2 & 1,7 & 3,9 \\
\hline Asociaciones estudiantiles & 91,7 & 4,8 & 3,5 & 8,3 \\
\hline Organizaciones artísticas & 91,3 & 6,0 & 2,7 & 8,7 \\
\hline Manifestaciones & 72,6 & 23,9 & 3,5 & 27,4 \\
\hline Otro & 94,3 & 3,2 & 2,5 & 5,7 \\
\hline
\end{tabular}

pación más elevadas, con un $46,1 \%$ de apoyo a actos políticos en redes sociales y un 63,3\% de reivindicación en las redes sociales.

Como segundo y tercer objetivo, nos plateábamos comparar la participación online de chicos y chicas estudiantes universitarios y del estudiantado de las diferentes ramas de conocimiento. Para ello se han realizado tablas de contingencia comprobando la significación estadística con la prueba Chi-cuadrado y el tamaño del efecto con la $V$ de Cramer. Debido a la extensión de la descripción de los resultados de estos análisis, y para facilitar la lectura de los mismos, en caso de relaciones significativas sólo se aportará el indicador de tamaño del efecto $V$ de Cramer, sin aportar los datos de Chi-cuadrado y su significación estadística. Se tomó esta decisión debido a que cuando aparecen relaciones estadísticamente significativas con un tamaño del efecto despreciable ( V Cramer<= 0,1) se considera que no hay relación (Volker, 2006). Cuando el tamaño del efecto sea, al menos, bajo y, en los casos que así se requiera, se indicará también el tipificado corregido. En todo momento se presentarán primero los resultados relativos a las reivindicaciones vía red social y, posteriormente el apoyo a actos políticos en las redes sociales. 
Tabla 2. Porcentaje de respuesta de los participantes del estudio a las preguntas de participación opinativa (cuatro primeros ítems) y de participación online (dos últimos ítems)

\begin{tabular}{l|l}
\hline & $\begin{array}{l}\text { Sí } \\
(\%)\end{array}$ \\
\hline Enviar artículos o cartas a los medios & 6,7 \\
\hline Dar opinión en programas de tv & 5,0 \\
\hline Participar en consultas o encuestas & 74,0 \\
\hline Contactar con gobierno & 5,1 \\
\hline Reivindicación vía red social & 66,3 \\
\hline Apoyo acto político en redes sociales & 46,1 \\
\hline
\end{tabular}

Los resultados indican que son especialmente reivindicativos vía red social ( $V$ Cramer $=0,12)$ el estudiantado de ciencias de la salud $(73,6 \%$, tipificado corregido $=3,5)$ y especialmente poco reivindicativos los y las estudiantes de arquitectura e ingeniería $(56,6 \%$, tipificado corregido $=3,4)$. Por su parte, apoyan actos políticos en las redes sociales $(V$ Cramer $=0,13)$ especialmente los y las estudiantes de Artes y Humanidades (65,2\%, tipificados corregidos $=4,2$ ) mientras que son más inactivos de lo esperado por azar los y las estudiantes de Ciencias de la Salud $(41,1 \%$, tipificado corregido= 2,4$)$.

Respecto a las diferencias en función del género es más frecuente que las chicas $(71,2 \%)$ realicen reivindicaciones vía red social a que lo hagan los chi$\cos (59,5 \%)$ (V Cramer $=0,122)$. Sin embargo, no aparecen diferencias significativas en función del género en el apoyo a actos políticos online (Chi-cuadra$\mathrm{do}=1,5 ; p=0,23$ ).

Para conocer si aquellos estudiantes universitarios más participativos en las redes sociales lo son también en la vida offline (objetivo 4), hipótesis del Gateway, se realizaron dos comparaciones de medias entre las dos variables de participación online, Reivindicación vía red social y Apoyo a actos políticos en redes sociales y, el indicador cuantitativo de participación directa offline. Los resultados indican que quienes utilizan las redes sociales para realizar reivindicaciones 
Figura 1. Porcentaje de reivindicación vía red social y apoyo político en redes sociales en función del género y la rama de conocimiento que estudian los participantes en el estudio

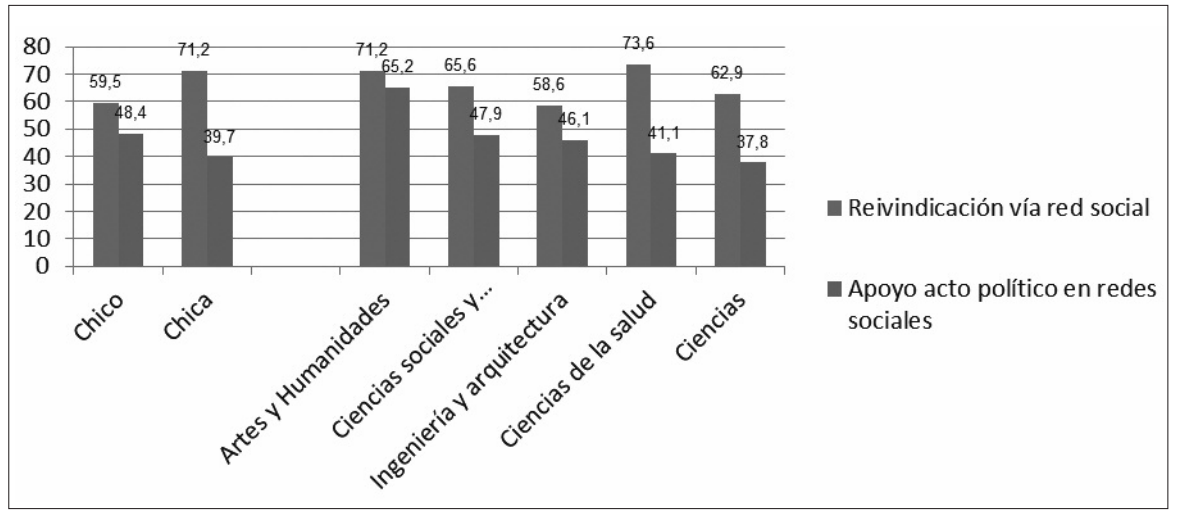

sociales tienen un índice de participación directa de 2,28 frente al 1,55 de quienes no las realizan, diferencias estadísticamente significativas $F(1,1337)=$ 23,56; $p<0,001$, aunque con un pequeño tamaño del efecto (Eta cuadrado= $0,017)$. En cuanto al apoyo a actos políticos en las redes sociales, aquellos jóvenes que participan online de la vida política son más participativos a nivel directo $(M=2,60)$ que quienes no participan de la vida política online $(M=1,57)$. Estas diferencias vuelven a ser estadísticamente significativas $F(1,1313)=$ 53,$25 ; p<0,001, y$ en este caso con un mayor tamaño del efecto (Eta cuadrado $=0,04)$, que no llega al 0,06 que se requiere para ser medio.

El resultado anterior parece apoyar la hipótesis Gateway. Sin embargo, en el índice de participación directa offline aparecen contenidos muy diferentes (ver tabla 1). Por este motivo, se realizaron pruebas de $X^{2}$ entre la prevalencia de cada una de las actividades de participación directa offline y, la reivindicación vía red social por una parte y el apoyo a actos políticos en redes sociales por otra. De nuevo, en caso de relaciones significativas sólo indicamos el tamaño del efecto ( $V$ de Cramer).

Así, existe una relación pequeña entre la reivindicación vía red social y el participar en partidos políticos (V Cramer $=0,10)$ y en ONGs (V Cramer=0,11). Sin embargo, no existe relación entre la reivindicación vía red social y participar en organizaciones religiosas ( $V$ Cramer $=0,06$ ), Movimientos locales o vecinales (V Cramer= 0,05), Organización deportiva (V Cramer= 0,05), Beneficiencia o redes solidarias ( $V$ Cramer $=0,07$ ), Organizaciones artísticas (V Cramer= $0,05)$ y, Manifestaciones (V Cramer $=0,08)$. La relación $\left(X^{2}\right)$ no llega a ser sig- 
Figura 2. Porcentaje de estudiantes universitarios que participan en la vida online y offline

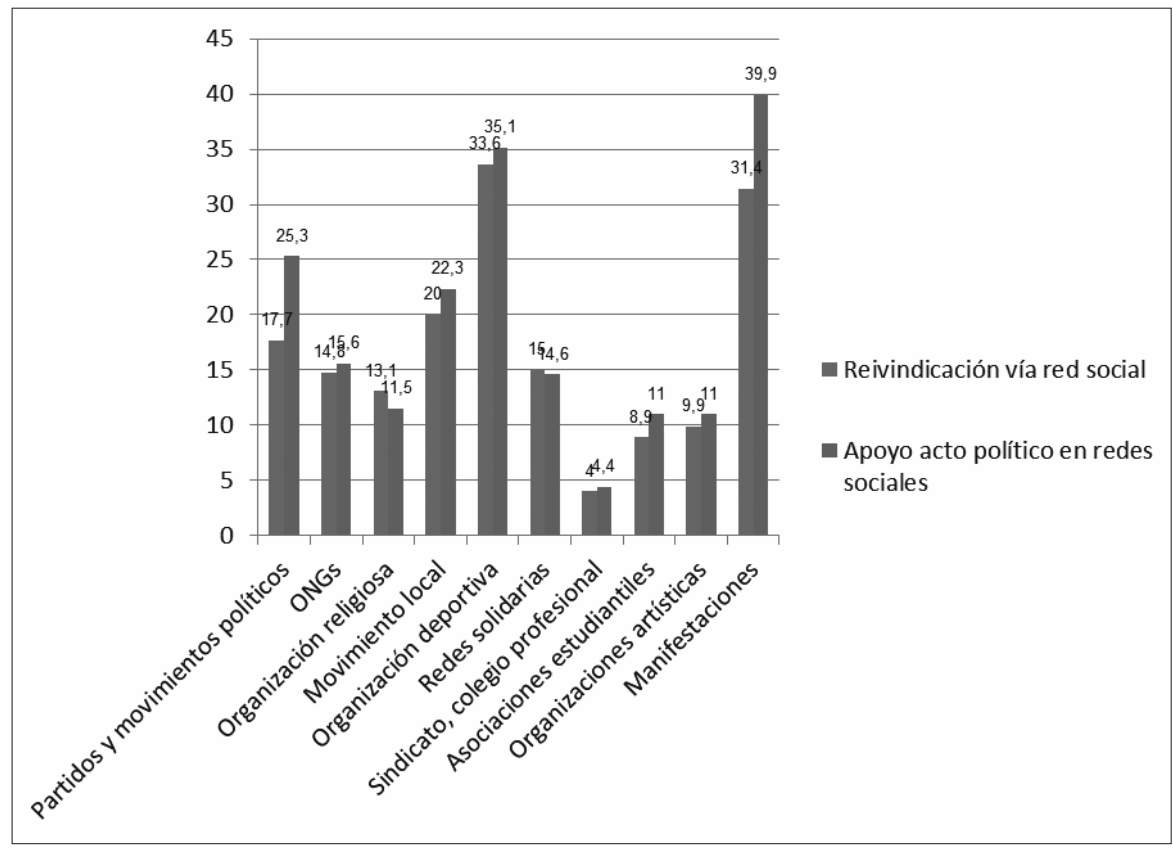

nificativa en cuanto a los Sindicatos o colegios profesionales y Asociaciones estudiantiles.

En cuanto a la variable apoyo a los actos políticos vía red social los resultados indican que quienes lo hacen a nivel online también participan en partidos políticos ( $V$ Cramer = 0,25, a partir de 0,3 se considera tamaño del efecto medio) y manifestaciones ( $V$ Cramer $=0,22)$. Sin embargo, no existe relación con participar en ONGS ( $V$ Cramer $=0,09$ ), Movimientos locales o vecinales (V Cramer = 0,09), Organización deportiva (V Cramer= 0,06), Asociaciones estudiantiles (V Cramer $=0,09)$ y Organizaciones artísticas (V Cramer $=0,07)$. La relación no llega a ser significativa entre el apoyo online a partidos políticos y la participación en organizaciones religiosas, de beneficencia o redes solidarias ni sindicato/cooperativa/colegio profesional.

De esta forma se ha podido constatar que, en lo referente a la participación directa offline, aunque las comparaciones de medias indicaban que la hipótesis del Gateway es correcta es decir, quienes más participan online también lo hacen offline, las pruebas más específicas de Chi-cuadrado indican que esta relación es así sólo cuando los contenidos entre la participación online y offline son simi- 
lares. Así, es más probable que los estudiantes universitarios que reivindican vía red social participen en partidos políticos u ONG, sin que tenga que aparecer la relación entre la reivindicación vía red social y el resto de actividades de participación social. Igualmente, es más probable que quienes en la red apoyan actos políticos también participen en estos partidos en la vida offline o acudan a manifestaciones, sin que exista relación con el resto de tipos de participación.

En cuanto a las variables relacionadas con la participación opinativa, existe relación de tamaño pequeño entre quienes realizan reivindicaciones vía red social y quienes participan en encuestas para dar su opinión (V Cramer $=0,15)$. Sin embargo, no existe relación entre aquellas personas que realizan reivindicaciones online y quienes envían artículos o cartas a los medios (V Cramer= 0,06). La relación no llega a significativa entre realizar reivindicaciones online y dar opinión en programas de Tv o radio, o contactar con el gobierno.

Respecto al apoyo político en las redes sociales, no se relacionó con Enviar artículos o cartas a los medios ( $V$ Cramer $=0,06$ ), o dar una opinión en programas televisivos o de radio ( $V$ Cramer $=0,08$ ). Sí se relacionó el apoyo político en las redes sociales con participar en consultas o encuestas ( $V$ Cramer= $1,2)$ y contactar con el gobierno (V Cramer $=1,4)$.

De nuevo, en lo referente a la participación opinativa, se encuentra que a la hora de establecer relaciones, el contenido prima sobre la forma de participación, online u offline. Así, quienes reivindican vía red social es más probable que participen en encuestas, pero no hay relación con otros contenidos de participación opinativa como contactar con el gobierno. Por su parte, quienes participan online apoyando actos políticos es más probable que contacten con el gobierno, pero no se relaciona con aspectos como enviar cartas a los medios.

\section{DISCUSIÓN Y CONCLUSIONES}

Los resultados de este trabajo muestran que la participación social offline de los universitarios de esta muestra es baja. De hecho, la mayor participación se produce acudiendo a manifestaciones o a organizaciones deportivas, y sólo son un $23,9 \%$ y un $21,4 \%$ de los jóvenes respectivamente. Sin embargo, la participación online se puede considerar elevada, ya que un $66,3 \%$ de los jóvenes realizan reivindicaciones a través de las redes sociales y un $46,1 \%$ apoyan actos políticos mediante esta vía. En cualquier caso, existen 20 puntos de diferencia entre la participación en un tema y otro, mostrando que el objeto de la participación moderará la cantidad y, posiblemente forma e implicación del tipo de participación social (Pérez, Berná y Arroyas, 2016).

Se confirma, de esta manera, la primera hipótesis que se planteó en este trabajo, y que coincide con los resultados expuestos por García-Galera y Del- 
Hoyo (2013) y García-Galera et al. (2014) con muestras no universitarias, en el sentido de que los jóvenes utilizan las redes sociales para algo más que divertirse o ampliar las redes sociales, las utilizan también para implicarse en el ámbito cívico, social o político. De esta forma, las redes sociales se configuran como un lugar de aprendizaje, intercambio y concienciación relativo al abordaje y regulación de cuestiones de interés público.

Existe la idea de que los jóvenes universitarios son más participativos socialmente que sus coetáneos que no universitarios (Watermeyer, 2015). Sin embargo, los porcentajes de participación de los jóvenes de este estudio son similares a los que se presentan en el Eurobarómetro (UE, 2015), por lo que no parece que los universitarios sean más participativos que el resto de jóvenes de nuestra sociedad.

En este trabajo quisimos ir un poco más allá y analizar si el área de conocimiento en el que los jóvenes universitarios se están formando influye en su participación social online. Los resultados llevan a rechazar las dos hipótesis planteadas: por una parte, cuando los estudiantes de ingeniería y arquitectura destacan, es para ser los menos activos a la hora reivindicar vía red social, por lo que no parece que el hecho de utilizar más las tecnologías y probablemente las nuevas tecnologías les lleve a una mayor implicación social usando estas herramientas. Por otra, los estudiantes de Ciencias de la salud son los más reivindicativos vía red social $y$, al mismo tiempo, los que menos apoyan actos políticos en estas mismas redes. No parece que el contenido de lo que se estudia lleve a una mayor o menor participación. Sin embargo, sí son los estudiantes de artes y humanidades los que más apoyan actos políticos, por lo que quizás, esta línea de investigación no deba obviarse del todo.

Respecto al género, hemos encontrado que las chicas son más reivindicativas vía red social que los chicos, mientras que no hay diferencias de género en el apoyo a actos políticos en las redes sociales. Este hecho lleva a aceptar parcialmente la hipótesis de partida de igualdad entre los sexos. Otros trabajos han encontrado mayor participación femenina en cuestiones orientadas a la comunidad, tales como ayudar a mejorar la sociedad o ayudar a las personas con necesidades (Crocetti, Jahromi y Meeus, 2012). Y buena parte de las reivindicaciones que se realizan en la red social son referentes a cuestiones de estas características. La ausencia de diferencias significativas en función del género en cuanto a la participación en actos políticos refrenda los datos del Eurobarómetro (UE, 2015) y llevan a la creencia de que, al menos en este contenido, la brecha de género está desapareciendo, y las mujeres están comenzando a ser agentes activos también en el mundo de la política. 
Finalmente, nuestros datos nos han permitido comprobar que los jóvenes universitarios más participativos en la vida online, lo son también en la vida offline, por lo que la hipótesis cinco se vería apoyada. Profundizando en esos mismos datos, hemos encontrado que esto no significa que los jóvenes universitarios activos lo son en cualquier tema y formato (online y offline), sino que el tópico o contenido prima sobre el formato. Así, aquellas personas que apoyan actos políticos en las redes sociales es más probable que contacten con el gobierno, participen en actos políticos o acudan a manifestaciones, es decir, que participen en cuestiones políticas tanto en la red como presencialmente, pero que no participen de otras aspectos de la vida civil como organizaciones deportivas, religiosas u ONGs. Se apoya, por tanto, la idea de que el entorno online no presenta un desplazamiento de otras formas de pertenencia, sino que permite ampliar los circuitos tradicionales de encuentro, socialización y participación (Winocur, 2006). Este hecho explicaría el escaso éxito que han tenido los proyectos que se han implementado con el objetivo de incrementar la participación en política de los jóvenes a partir de la e-participación (Saebo, Rose y Flak, 2008). Con estos datos volvemos a preguntarnos: ¿es la participación en las redes sociales una puerta de entrada o Gateway para la participación en la vida offline o más bien son los jóvenes más participativos quienes lo son en uno y otro entorno? Solo un estudio longitudinal podría responder con escrupulosidad a esta pregunta, lo que nos lleva a las limitaciones de este trabajo.

La primera limitación es precisamente el diseño transversal de la investigación. Sin embargo, el hecho de que los resultados coincidan con otras investigaciones transversales de nuestro entorno (García-Galera et ál., 2014) pero con muestras y formatos diferentes (frente a datos recogidos online en la red social, datos de encuestas en papel de estudiantes universitarios) nos lleva a postular este trabajo como un indicador más para la aceptación de la hipótesis de la puerta de entrada.

En cualquier caso, la vida online es cada vez más poderosa: las actuaciones a través de plataformas virtuales como change.org o avaaz, con uno u otro signo político, acaban teniendo un resultado en la vida real de las personas. También encontramos apoyo a actos políticos en las redes que acaban suponiendo un cambio de políticas reales en la vida pública. Es decir, quizás debamos eliminar la dicotomía offline - online en el convencimiento de que tan real es un tipo de entorno como el otro, y que ambos pueden tener efectos contrastables en el día a día de las personas.

Por otra parte sólo teníamos dos preguntas relativas a la participación social online. Quizás, si el cuestionario hubiera constado de más preguntas, en las que se especificara en el caso de reivindicaciones vía redes sociales qué tipo de 
reivindicaciones, o se preguntara por apoyo a otras organizaciones no políticas, los resultados de este trabajo hubieran sido aún más precisos.

A pesar de estas limitaciones, creemos que este trabajo ha ampliado el conocimiento existente sobre la participación social de los y las jóvenes universitarios en España. El tipo de análisis efectuado, la amplitud de la muestra, su pertenencia a distintas áreas de conocimiento y el importante número de preguntas permite aportar un conocimiento válido, fiable y también fiel respecto a hasta qué punto participación online y offline coinciden o se diferencian. Hemos aportado y comenzado a responder una nueva pregunta de investigación, ¿influye el contenido de los estudios en la participación social online de los estudiantes universitarios? Y hemos contribuido a mostrar que las diferencias de género en cuanto a participación social están disminuyendo.

Asumir responsabilidades cívicas es una de las tareas evolutivas a conseguir durante la juventud (Havighurst, 1972). Así, participar a nivel social, con la responsabilidad cívica que implica, sería un objetivo que la sociedad espera que la persona cumpla al inicio de su vida adulta que por una parte, aumentará el sentido de competencia de la persona dentro de su comunidad y, por otra, le servirá como preparación para afrontar nuevas tareas propias de la madurez. En este sentido, y subrayando la importancia de la participación social durante la juventud, diferentes investigaciones relacionan la participación social con el ajuste psicosocial de jóvenes y adolescentes (McPherson, et ál. 2013; McPherson, et ál. 2014). Estos trabajos vendrían a demostrar que la implicación y la participación social (ya sea virtual o presencial) redundan no sólo en la mejora de la sociedad en la que los y las jóvenes habitan, sino también en su propio bienestar personal.

Sin duda, dada la trascendencia que las redes sociales han adquirido en nuestra sociedad del S. XXI cada vez será mayor la participación social de nuestros jóvenes a través de los entornos virtuales. Una participación social que debería redundar en una nueva e-generación de ciudadanía más crítica, que permita el empoderamiento desde la educación con movimientos sociales y políticos capaces de llevar a la sociedad hacia mayores cotas de igualdad y equilibrio social. A través del presente trabajo hemos profundizado en la participación social de los universitarios españoles en las redes sociales. Estamos convencidos de que este tipo de trabajos son fundamentales de cara al diseño de intervenciones educativo-preventivas para potenciar la integración de los y las jóvenes y su participación activa en la sociedad.

\section{APOYOS}

Investigación financiada en el Plan Estatal 2013-2016 Retos - Proyectos I+D+i por el Ministerio de Economía y Competitividad (referencia EDU2013-45687-R) 


\section{REFERENCIAS}

American Psychological Association (2014). Civic engagement. Descargado en enero de 2017 de https://goo.gl/P5AUJC

Adler, R. P., y Goggin, J. (2005). What do we mean by "civic engagement"? Journal of Transformative Education, 3(3), 236-253. doi: 10.1177/1541344605276792

Adúriz, I., y Ava, P. (2006). Construccción de ciudadanía: experiencia de implementación de un índice de participación ciudadana en América Latina. América Latina Hoy, 42, 15-35. Disponible en: < https://goo.gl/0gJeUU>

Amna, E., Ekstrom, M., Kerr, M. et al. (2009). Political socialization and human agency: The development of civic engagement from adolescence to adulthood. StatsvetenskapligTidskrift, 111(1), 27-40. Descargado en octubre de 2016 de https://goo.gl/ 5IhbVV

Archila, M. (2012). El movimiento estudiantil en Colombia. Revista del observatorio social de América Latina, 31, 71-103. Descargado en diciembre de 2016 de https:// goo.gl/4DgLaA

Ayala, T. (2014). Redes sociales, poder y participación ciudadana. Revista Austral de Ciencias Sociales (26), 23-48. doi:10.4206/rev.austral.cienc.soc.2014.n26-02

Boyd, D. y Ellison, N. (2007). Social Network Sites: Definition, History, and Scholarship. Journal of Computer-Mediated Communication 13, 210-230. doi: 10.1109/emr.2010.5559139

Crocetti, E., Jahromi, P., y Meeus, W. (2012). Identity and civic engagement in adolescence. Journal of adolescence, 35(3), 521-532.

doi: 10.1016/j.adolescence.2011.08.003

Ganuza, E., y Francés, FJ. (2015). Citizen Participation in Europe: A Comparative Analysis from the Sociopolitical Contexts. OBETS. Revista de Ciencias Sociales, 10(1), 235-260. doi: 10.14198/OBETS2015.10.1.09

García-Galera, M.C. y Del-Hoyo, M. (2013). Redes sociales, un medio para la movilización juvenil. Zer- Revista de Estudios de Comunicación, 18(34), 111-125.

García-Galera, M.C., Del-Hoyo, M. y Fernández, C. (2014). Jóvenes comprometidos en la Red: El papel de las redes sociales en la participación social activa [Engaged Youth in the Internet. The Role of Social Networks in Social Active Participation]. Comunicar, 43(XXII), 35-43. doi: 10.3916/c43-2014-03

García, A., López de Ayala, M. C. y Catalina, B. (2013). Hábitos de uso en Internet y en las redes sociales de los adolescentes españoles. [The Influence of Social Networks on the Adolescents' Online Practices]. Comunicar, 41(XXi), 195-204.

doi: 10.3916/c41-2013-19

González, G.; Becerra, M.T. y Berenice, M. (2016). Ciberactivismo: nueva forma de participación para estudiantes universitarios [Cyberactivism: A new form of participa tionforUniversityStudents]. Comunicar, 46(XXIV), 47-54.

doi: 10.3916/c46-2016-05

Havighurst, R.J. (1972). Developmental tasks and education. New York: Davis McKay. 
Jacobson, T., y Culver, S. H. (2012). Alfabetización mediática como método para fomentar la participación cívica [Media Literacy and Its Use as a Method to En courageCivicEngagement]. Comunicar, XX(39), 1-16. doi: 10.3916/c39-2012-02-07

Kimbrough, A. M., Guadagno, R. E., Muscanell, N. L.et al. (2013). Gender differences in mediated communication: Women connect more than do men. Computers in Human Behavior, 29(3), 896-900. doi: 10.1016/j.chb.2012.12.005

Macafee, T., y De Simone, J. J. (2012). Killing the bill online? Pathways to young people's protest engagement via social media. Cyberpsychology, Behavior, and Social Networking, 15(11), 579-584. doi: 10.1089/cyber.2012.0153

McPherson, K. E., Kerr, S., Morgan, A., et al. (2013). The association between family and community social capital and health risk behaviours in young people: an integrative review. BMC Public Health, 13, 971. doi: 10.1186/1471-2458-13-971

McPherson, K. E., Kerr, S., McGee, E., et al. (2014). The association between social capital and mental health and behavioural problems in children and adolescents: an integrative systematic review. BMC psychology, 2(1), 7.

doi: 10.1186/2050-7283-2-7

Ministerio de Educación, Cultura y Deporte (MECD, 2015). Datos y Cifras del Sistema Universitario Español (Data and Figures of the Spanish University System). Curso 2014/15. Madrid: Ministerio de Educación, Cultura y Deporte. Retreived May 25, 2016 from http://www.mecd.gob.es/educacion-mecd/areas-educacion/univer sidades/estadisticas-informes/datos-cifras.html

Montes, R. (2015). Miles de estudiantes chilenos salen a la calle en medio de la crisis política. El país internacional, 16 de abril de 2015, descargado en noviembre de 2016 de: https://goo.gl/XcG3Bl

Pérez, P.L., Berná, C., y Arroyas, E. (2016). The Conversation on Political Issues on Twitter: An Analysis of the Participation and Frames in the Debate on the 'Wert Law' and Evictions in Spain. OBETS. Revista de Ciencias Sociales, 11(1), 311-330. doi:10.14198/OBETS2016.11.1.12

Pew Research Center (2012). Social Networking Popular Across Globe. Arab Publics Most Likely to Express Political Views Online, descargado en noviembre de 2016 de: https://goo.gl/OyQyN

Sæbø, Ø., Rose, J., y Flak, L. S. (2008). The shape of eParticipation: Characterizing an emerging research area. Governmentinformationquarterly, 25(3), 400-428. doi: 10.1016/j.giq.2007.04.007

Sánchez-Rodríguez, J., Ruiz-Palmero, J., y Sánchez-Rivas, E. (2015). Uso problemático de las redes sociales en estudiantes universitarios. Revista Complutense de Educación, 26, 159-174. doi: 10.5209/rev_rced.2015.v26.46360

Subrahmanyam, K., Reich, S. M., Waechter, N., et al. (2008). Online and offline social networks: Use of social networking sites by emerging adults. Journal of applied developmental psychology, 29(6), 420-433. doi: 10.1016/j.appdev.2008.07.003

Thompson, S. y Ches, E. (2012). Frazzled by facebook? An exploratory study of gender differences in social network communication among Undergraduate men and women. College Student Journal, 46, 88-98. 
Unión Europea (UE, 2015). Flash Eurobarometer 408. "European Youth". TNS Political y Social. Descargado en enero de 2017 de https://goo.gl/7US7Xk

Uzcátegui, R. (2014). Movilizaciones estudiantiles en Venezuela. Del carisma de Chávez al conflicto en redes. Nueva sociedad, 251, 153-165. Descargado en noviembre de 2016 de https://goo.gl/piHAz3

Volker, M.A. (2006). Reporting effect size estimates in school psychology research. Psychology in the Schools, 43(6), 653-672. doi: 10.1002/pits.20176

Watermeyer, R. (2015). Lost in the 'third space': the impact of public engagement in higher education on academic identity, research practice and career progression. European Journal of Higher Education, 5(3), 331-347. doi: 10.1002/pits.20176

Winocur, R. (2006). Internet en la vida cotidiana de los jóvenes. Revista Mexicana de Sociología, 68(3), 551-580. Disponible en: https://goo.gl/9msUoV

Zhou, Y. y Pinkleton, B.E. (2012). Modeling the effects of political information source use online expression on young adults' political efficacy. Mass Communication and Society, 15(6), 813-830. doi: 10.1037/e521582014-078

\section{NOTAS BIOGRÁFICAS}

IZARNE LIZASO ELGARRESTA. Profesora Doctora Agregada del área de Psicología Evolutiva y de la Educación, del Departamento de Procesos Psicológicos Básicos y su Desarrollo de la Facultad de Psicología en la Universidad del País Vasco. Ha trabajado como psicóloga en centros gerontológicos y su investigación se centra tanto en la nueva imagen de la vejez como en dar a conocer la adultez emergente y sus características. Toda la autoría forma parte del estudio sobre la transición a la adultez en España.

(http://grupos.us.es/transadultez/)

INMACULADA SÁNCHEZ-QUEIJA. Profesora Contratada Doctora acreditada a Titular del Dpto. de Psicología Evolutiva y de la Educación de la Universidad de Sevilla. Ha centrado su investigación en las etapas evolutivas de la adolescencia y la adultez emergente, tanto en temas relativos a la salud positiva como en temas de relaciones interpersonales.

Página web: http://personal.us.es/queija/

Orcid: https://orcid.org/0000-0002-4688-4206

ÁGUEDA PARRA JIMÉNEZ. Profesora Titular del Dpto. de Psicología Evolutiva y de la Educación de la Universidad de Sevilla. Ha centrado su investigación en las relaciones familiares y el desarrollo positivo durante la adolescencia y es investigadora principal del estudio La Transición a la Adultez en España: 
estudio sobre las claves del ajuste psicosocial y fundamentos para su intervención preventiva.

Página web: http://personal.us.es/aparra/

Orcid: https://orcid.org/0000-0001-8435-2422

ENRIQUE ARRANZ FREIJO. Catedrático de Psicología de la Familia, imparte docencia en el área de Psicología Evolutiva y de la Educación, del Departamento de Procesos Psicológicos Básicos y su Desarrollo de la Facultad de Psicología en la Universidad del País Vasco. Su investigación se ha centrado principalmente en las competencias parentales de familias con hijos e hijas tanto en edad infantil como adolescente.

Recibido: 21-11-2017

Aceptado: 09-08-2018

(C) (7) Licencia Creative Commons Reconocimiento (CC BY 4.0) 



\title{
PERFILES DE OPINIÓN DE LOS ESTUDIANTES UNIVERSITARIOS ACERCA DE LA HOMOPARENTALIDAD EN EL CONTEXTO ACTUAL DE METAMORFOSIS FAMILIAR OPINION PROFILES OF THE UNIVERSITY STUDENTS ABOUT HOMOPARENTHOOD IN THE FAMILIAR METAMORPHOSIS CURRENT CONTEXT
}

\author{
José Ocón-Domingo \\ Universidad de Granada, España \\ joseocon@ugr.es \\ Clemente Rodríguez-Sabiote \\ Universidad de Granada, España \\ clerosa@ugr.es \\ Daniel Álvarez-Ferrándiz \\ Universidad de Granada, España \\ ferrandiz98@correo.ugr.es
}

Cómo citar / citation

Ocón-Domingo, J., Rodríguez-Sabiote, C. y Álvarez-Ferrándiz, D. (2018) "Perfiles de opinión de los estudiantes universitarios acerca de la homoparentalidad en el contexto actual de metamorfosis familiar". OBETS. Revista de Ciencias Sociales, 13(2): 569-591. doi: 10.14198/OBETS2018.13.2.05

\section{Resumen}

El presente trabajo se propone como objetivos de estudio determinar la opinión de estudiantes universitarios acerca de la homoparentalidad, comprobar si existen, o no, diferencias estadísticamente significativas al cruzar dicha opinión con diferentes variables de identificación con el objetivo final de establecer un perfil característico de los estudiantes con mejor o peor actitud hacia la dicha tipología familiar. La metodología utilizada se basa en un diseño descriptivo tipo encuesta aplicado sobre un tamaño muestral que asciende a 332 
estudiantes que han sido seleccionados mediante muestreo probabilístico estratificado en la Facultad de Educación de la Universidad de Granada. Los resultados obtenidos apuntan a una opinión, en general, favorable hacia dicha tipología familiar si bien, tres de las cuatro variables identificativas han marcado diferencias estadísticamente significativas. A partir de esta premisa hemos podido establecer como conclusión fundamental un perfil de alumnado universitario más favorable hacia la homoparentalidad que estaría conformado por mujeres de todas las titulaciones objeto de investigación, menos el Grado de Pedagogía, que conocen a parejas homoparentales y que proceden, indistintamente, de ámbitos de nacimiento rural o urbano.

Palabras clave: Familia homoparental, diversidad, formación del profesorado; árboles de decisión.

\section{Abstract}

This paper proposes as objectives of the study to determine the opinion of university students about homoparenthood, to verify if there are, or not, statistically significant differences when crosscheking opinion with different identification variables with the final objective of establishing a characteristic profile of the students with the best or worst attitude towards homoparenthood. The methodology used is based on a descriptive design type survey applied on a sample size of 332 students that have been selected by stratified probabilistic sampling of the Faculty of Education of the University of Granada. The results obtained suggest that the opinion, in general, is in favour of this family typology, while it is true that three of the four identification variables make statistically significant differences. Starting out from this premise, we have been able to establish as a main finding a profile of university students more favourable toward homoparenthood which is composed of women from all Degrees, except Degree in Pedagogy, who know same-sex couples, whose places of birth are, indistinctly, rural or urban

Keywords: LGBT parenting; diversity; teacher training; answer trees.

\section{Extended Abstract}

This paper proposes as objectives of the study to determine the opinion of university students about homoparenthood, to verify if there are, or not, statistically significant differences when crosscheking opinion with different identification variables with the final objective of establishing a characteristic profile of the students with the best or worst attitude towards homoparenthood. In terms of sample, sample characteristics and sampling process we must emphasise that the sample size is 332 students who have been selected using stratified probabilistic sampling with only stratum. The sample size determination procedure starts from a population of approximately 6000 students, a confidence level of 0.95 and a sampling error of $\pm 5 \%$ with unknown probabilities $\mathrm{p}=\mathrm{q}=0.5$. As for the sample characteristics the average age of students is 20.03 years with a standard deviation of $3.69,19 \%$ corresponding to men and the remaining $81 \%$ to women. In relation to birth $39.2 \%$ were born in rural areas and $60.8 \%$ in urban areas. Also $37.7 \%$ do not know any cases of homo- 
parental families, while $62.3 \%$ do. Finally, in terms of their degree, $23.8 \%$ correspond to Social Education, 36.9\% to Primary Education, 26.8\% to Infant Education and $17.5 \%$ remaining of Pedagogy.

As regards the data collection we have been administered an adaptation of the Scale Attitude Towards Homoparenthood Families (SATHF) was used by Ramírez, Moliner and Vicent (2008). This scale consists of 20 items in Likert format with five possible level of measurement from 1: never / strongly disagree to 5: always / strongly agree. We have included five identification variables that act as grouping variables to denote future comparisons. These variables are age, gender, degree, scope of birth and whether you know homoparenthood families. With respect to terms of reliability and validity of scale. Firts reliability as internal consistency, since we only have one administration. To do this we have calculated the reliability coefficient of Cronbach's $\alpha$ that has yielded a value of $\alpha=0.81$. Consequently, we can affirm that the AHFM scale administered to our sample is consistent and stable and that the different items that conform it, being highly correlated, guarantee convincingly that they are measuring the same latent variable.

From the second parameter, validity we contemplate the validity of content or degree in which the items that make up the scale actually measure the construct for which they have been developed. For your guarantee we have taken a scale already developed and used in a previous investigation (see section immediately above). We have also contemplated the concurrent criterial validity. For this we have calculated the corrected item-total correlation, that is, the correlation of each item individually with the total test (as internal criterion) minus the item in question. In all cases, correlation coefficients $r>0.35$ have been obtained, which is why we can affirm that each item measures individually what the total of the scale (uniqueness).

For the data analysis of the information collected using the scale described above, we used the quantitative data analysis program SPSS v.24. We have performed analysis of a descriptive type (arithmetic means), inferential (nonparametric type of significance test) and multivariate (hierarchical segmentation using the CHAID-Chi-Squared Automatic Interaction Detection technique) for the fulfillment of the fundamental research objective. As a procedure prior to any type of analysis, we have re-codified the inverse items and, in addition, we have created a new variable of dummy type made up of the average sum of the 20 items that has served as a global measure of the variable dependent opinion on homoparenthood families.

On the other hand, and with the aim of establishing student profiles, we highlight the possible differential effects (statistically significant) between the different levels that make up the identification variables contemplated. Thus, with regard to the sex variable, we find that women value homosexual families better than men, without detriment to the favorable opinion of men. We also confirm that those students who know same-sex couples value homoparenthood families better than those who do not know them, although this does not mean, as in the case of sex, that those students who know them do not have a good assessment of families. Regarding the degrees that have participated in this 
research (Degree in Early Childhood Education, Degree in Social Education, Degree in Pedagogy and Degree in Primary Education), it is noted that it is the degree of Pedagogy that has shown less agreement with families homoparentales, although as in the previous two cases, its valuation remains above 4 and, therefore, can be considered as moderately important. The totally opposite case has been from the field of birth of the students. In this particular case there have been no statistically significant differences between the rural vs. urban environment. This means, therefore, that students of rural and urban origin value similarly to homoparenthood families. In any case, this assessment can be considered very favorable to homoparenthood families.

Precisely the presence of statistically significant differences between the different levels of the identification variables justifies the development of a multivariate analysis technique capable of establishing profiles from the division of a "tree" in nodes. This procedure is CHAID technique. Once implemented, it has been confirmed the presence of two well differentiated profiles:

a) Students who are moderately in favor of homoparenthood families that would be made up, essentially, by men of the Degree of Pedagogy who do not know homoparental couples and who come from both the rural and urban areas.

b) The students who are very in favor of the homoparenthood families that would be constituted, in essence, by women of all the grades under investigation, less the Degree of Pedagogy, who do know homoparenthood couples and who come, in the same way, indistinctly from rural and urban areas.

Finally, we must highlight the limitations of this research and improvement proposals to try to overcome them. The first is the sample size used. We think that a larger sample size that includes more degrees from the University of Granada would significantly improve the power of generalization of the established conclusions. We also believe that the administration of some kind of qualitative data collection technique can help in the methodological triangulation of the data and give validity and legitimacy to the conclusions and findings of the study.

\section{INTRODUCCIÓN}

De todas las investigaciones que abordan el tema de la familia, con independencia de la perspectiva que se adopte para su estudio, se deriva una consecuencia ineludible: la importancia que, históricamente, viene teniendo esta institución en cualquier tipo de sociedad. Así figura en el artículo 16.3, de la Declaración Universal de los Derechos Humanos, de 10 de diciembre de 1948: "La familia es el elemento natural y fundamental de la sociedad y tiene derecho a la protección de la sociedad y del Estado". Pero esta permanencia no impide que las dinámicas y los recorridos de vida intrafamiliar se perciban inmersas en un intenso proceso de cambio (Alberdi, 1999; Meil, 1999; Jurado, 2005; EspingAndersen, 2013). De ahí que el modelo de familia tradicional, pese a continuar 
como referente, haya evolucionado hacia otros modelos no tan bien delimitados. Por ello muchos autores, en lugar de "familia", prefieren utilizar el término "familias", como forma de cubrir la diversidad actual de formas coexistentes (Berger y Berger, 1983). Estas modificaciones no significan, para la mayoría de los autores, una decadencia o un debilitamiento del modelo tradicional de familia nuclear. Constituyen, más bien, el resultado de una adaptación a entornos crecientemente complejos, que parecen requerir de las personas otras opciones matizadas y diversas (Díaz, Chuliá y Fernández, 2000).

Una encuesta, a cargo del CIS (2004), abunda en estas cuestiones. Frente a la división de roles propios de la familia tradicional, un $88,4 \%$ de los entrevistados, se muestra "muy de acuerdo" o "bastante de acuerdo" con que hombre y mujer deben contribuir a los ingresos familiares; así como un 92,9\% elige entre estas dos opciones, cuando opinan sobre el reparto de las tareas domésticas. Estos cambios de mentalidad hacen que hoy contemos con la convivencia de un mayor abanico de modelos de organización familiar, dotados, por otra parte, de características propias. Nos referimos, básicamente, a las familias adoptivas, reconstituidas, cohabitantes, monoparentales y homoparentales. Y es que, en palabras de Alberdi (1995):

La familia en los albores del siglo XXI, ya no es la de antaño ni las normas jurídicas pueden ser las mismas. Una sociedad plural basada en relaciones de igualdad y libertad dan lugar a muy diversas formas de relaciones familiares todas ellas válidas y aceptadas por el derecho (p. 382).

Entre estas nuevas realidades familiares, la familia homoparental resulta especialmente novedosa. La singularidad de los actores implicados en estos procesos tan particulares y los elementos ideológicos que comporta, han hecho que, en nuestro país, hayan permanecido bajo un gran oscurantismo y ostracismo hasta finales del siglo XX. Hasta los años noventa han carecido de una identidad y reconocimiento social; no existiendo, siquiera, un nombre para dirigirse a ellas. Tampoco figuraban en los recuentos oficiales del Instituto Nacional de Estadística (2004), referidos al censo de 2001 (González, Chacón, Gómez, Sánchez y Morcillo, 2004). No obstante, Cortina y Cabré (2010) presentan, a partir de una explotación de los datos del Censo de 2001, una caracterización sociodemográfica de dichas uniones en España. Entre otros detalles, indican, que están formadas por cónyuges jóvenes, con un elevado nivel de instrucción y con residencia mayoritaria en áreas urbanas. El número de uniones de hombres es dos veces mayor que el de mujeres, elemento que refuerza la tesis que apunta a una mayor incidencia de la homogamia masculina: 6.996 (por hombres) y 3.478 (por mujeres). Esto representa una tasa del 1.1 por cada mil parejas. 
Este anonimato, si miramos retrospectivamente, no resulta tan extraño en España, pues las connotaciones de los casi cuarenta años bajo el marco político y social franquista, han calado de modo especial en el colectivo homosexual. Este régimen, que adoptará la moral católica y permitirá la omnipresencia del clero en los distintos organismos y actividades del Estado (Nacionalcatolicismo), entre otros muchos aspectos, destacará por una política represora de la homosexualidad. Claras manifestaciones fueron el riesgo permanente de los integrantes de este colectivo de ser juzgados según las directrices de la Ley de Vagos y Maleantes (1933) y de la Ley de Peligrosidad y Rehabilitación Social (1970), así como de ser encarcelados en el penal-reformatorio de Huelva, creado para la rehabilitación de los mismos (Soriano, 1978; Ocón, 2013).

Con la aprobación de la Constitución Española de 1978 y la democracia se consagra la igualdad, sin discriminación, de todos los españoles en su artículo 14. De modo que la homosexualidad, desde esas fechas, transita del ámbito penal al ámbito civil, demandando el colectivo un trato de igualdad con los heterosexuales, incluida la posibilidad de matrimonio. Este debate de gran trascendencia política y social, en torno a las posibilidades jurídicas de esta opción matrimonial y a su conveniencia como nueva forma de familia, se ha venido intensificando con el transcurrir democrático y con las experiencias de otros países (Ocobock, 2018). Estos cambios de la sociedad española, según Lázaro (2016), sirvieron de base para una interpretación evolutiva y de cultura jurídica del Derecho, antes que normativa. Es decir, tomando como apoyo el cambio de las circunstancias sociales que, a la postre, darían lugar a la aprobación del matrimonio homosexual a pesar de que todavía es importante el rechazo de determinados núcleos de la sociedad española que sigue mirando con recelo, cuando no con burla y desprecio al colectivo LGTB (Amat y Moliner, 2017). Precisamente, este aspecto tiene un difícil afrontamiento al estar arraigado en profundas estructuras cognitivas de carácter conservador en la sociedad, como es el caso particular que nos muestra Perales (2018) en un estudio implementado en Australia.

Así ha quedado reflejado en el estudio del CIS (2004), recogido previamente, donde se señala cómo un $67,7 \%$ de los encuestados considera que las parejas estables del mismo sexo deben disfrutar de los mismos derechos y obligaciones que las heterosexuales. Un 56,9\% se muestra partidario del matrimonio entre homosexuales, y un 32,2\% rechaza esta alternativa. Por otra parte, un $42,4 \%$ de los consultados está "muy o bastante de acuerdo" con la adopción por parejas homosexuales, mientras que, un 48,1\%, se manifiesta "poco" o "nada de acuerdo" con esta opción. Al respecto, un estudio reciente de Rodríguez (2018) en Colombia concluye que cada vez hay un mayor desarrollo norma- 
tivo que regula la adopción para familias del mismo sexo en paralelo a un mayor apoyo desde la ciudadanía. Por su parte, Montes, González, López-Gaviño y Angulo (2016), tratan de conocer los cambios en el grado de apertura y de aceptación de las familias homoparentales españolas, antes y después de la aprobación del matrimonio entre personas del mismo sexo en 2005. Se entrevistó a 66 familias, encabezadas por parejas de lesbianas (48) o de gays (18), que llevaban juntas, al menos desde 2004, y tenían hijos o hijas menores de edad en común. Los resultados obtenidos indican que, antes del cambio legislativo, en el ámbito de las amistades era donde las parejas muestran una mayor apertura, seguido del de los familiares, siendo mucho menos visible el cambio en el ámbito laboral. Tras aprobarse la ley aumenta, tanto el grado de apertura, como la aceptación percibida en todos los contextos estudiados: amistades, familia y laboral, resultando estas diferencias estadísticamente significativas. Otros estudios de ámbito internacional como los de Machín (2016) en Brasil y Delaunay (2018) en Francia y Portugal muestran que el proceso de adopción en familias homoparentales es un aspecto en franca consolidación normativa y social, a la par que también aparecen nuevas controversias en aspectos relacionados, sobre todo, con la reproducción asistida.

Todo este proceso ha culminado con la aprobación de la Ley 13/2005, de 1 de julio, "por la que se modifica el Código Civil en materia de derecho a contraer matrimonio"; así como otros derechos relacionados con el mismo: paternidad conjunta, herencia o pensión (Boletín Oficial del Estado, 2005). Por otra parte, la presencia de parejas homosexuales que deseaban formar una familia y de otras que ya disponían de ella, al contar con hijos nacidos de relaciones heterosexuales previas, por inseminación artificial o por vía de la adopción individual, se ha venido perfilando como una realidad en la sociedad española y su incremento parece incuestionable (Sánchez Díaz, Podestá González y Garrido, 2018). También debemos anotar la opción, en algunos países, de los servicios por subrogación de las denominadas "madres de alquiler", "de sustitución" o "portadoras", cuya regulación legal, avivada por los grupos LGBT, se presume próxima en España.

Pero, en definitiva, quizás el planteamiento más importante, desde una perspectiva psicológica y social, debe centrarse en discernir la capacidad real que estas familias tienen a la hora de satisfacer, en su caso, las distintas necesidades de los menores. No conviene olvidar que, lo prioritario, es salvaguardar el interés del menor y su bienestar psicológico, amén de los efectos positivos que esta realidad pudiera reportar a los contrayentes o, en su caso, al resto de integrantes de la unidad familiar (Ocón, 2013). Pese a la existencia de distintas posiciones, nos atreveríamos a afirmar desde esta posición psicosocial, que las resis- 
tencias existentes en esta materia vienen girando en torno a las siguientes consideraciones fundamentales (Ocón, 2002: 100 y ss.):

Se recogen inconvenientes acerca de la transmisión de aquellos contenidos que la familia heterosexual tiene encomendados como principal agente socializador. Nos estamos refiriendo, básicamente, a los relacionados con el aprendizaje de los roles de género. También, si el hecho de no contar con una madre y un padre, puede conllevar un inadecuado desarrollo psicológico, un rechazo social y, en consecuencia, problemas relacionados con la integración social. Finalmente, la existencia de un recelo a que los hijos puedan seguir la misma orientación sexual de los padres adoptivos y "caer" en la homosexualidad.

Con cierta independencia del peso de las razones anteriores que, por otra parte serían susceptibles de diversas opiniones, hay que subrayar, que desde las primeras investigaciones, en los años 70, se evidencia un correcto desarrollo de los niños/as cuya vida transcurre en el seno de una familia homoparental. En este sentido, señalaba Herrero Brasas, en 1993, que los estudios llevados a cabo en este EE.UU., no han mostrado ningún efecto negativo sobre estos niños, ni tampoco se incrementa en estas familias la posibilidad de que desarrollen una orientación homosexual. En esta dirección, opina Gilgoff (2004), que tras tres décadas de investigación sociológica en Estados Unidos, la Asociación de Psicología Americana, la Academia de Pediatras Estadounidense, la Asociación Nacional de Asistentes Sociales y la Asociación de Abogados Estadounidenses han hecho declaraciones públicas aprobando la paternidad gay . También FríasNavarro, Pascual, Monterde-Bort (2003) y González (2005), recogen estas manifestaciones institucionales. Gilgoff (2004: 5), por su parte, hace referencia a las palabras de Judith Stacey, catedrática de Sociología, Género y Sexualidad de la Universidad de Nueva York: "no hay un solo estudio que haya hallado diferencias [entre los niños de padres gay y de padres heterosexuales] que puedan interpretarse como perjudiciales". Estudios más recientes, entre otros los de Juárez Mendez y Chávez Intriago (2016), Placeres Hernández, Olver Moncayo, Rosero Mora, Urgilés Calero y Abdala-Jalil Barbadillo (2017) y Sánchez Díaz, Podestá González y Garrido (2018) también llegan a conclusiones semejantes negando efectos perjudiciales en los hijos e hijas criados dentro del seno de una familia homoparental.

Respecto a que los hijos de gays y lesbianas puedan manifestar trastornos de identidad, estos primeros estudios, prácticamente en su totalidad, anotan la inexistencia de diferencias significativas entre los hijos criados por homosexuales y heterosexuales. A modo de ejemplo, podemos citar los trabajos de Steckel (1987); Brewaeys, Ponjaert, Van Hall y Golombok, 1997 y más recientemente los de Gates (2015) y Farr (2017). En todos ellos se concluye que no hay mayo- 
res niveles de trastorno de identidad en hijos de parejas homoparentales en comparación a sus iguales de familias heterosexuales.

Tampoco las hay en lo que respecta a la tipificación sexual, es decir, al proceso por el cual se aprende lo que, teóricamente, es considerado propio de cada sexo: Cramer (1986); Gottman (1989); Green y Bozzett (1991); Patterson (1992, 1997). En la misma dirección concluyen los estudios sobre la mayor posibilidad, por parte de los hijos e hijas de gays y lesbianas, de seguir la orientación sexual de sus padres y madres: Hotvedt y Mandel (1982); Green y Bozett (1991); Falk (1994); Golombok y Tasker (1996) y los más novedosos de Ocobock (2018) y Luke (2018). Asimismo, indican, que la comparación del ajuste psicológico entre hijos de padres/madres homosexuales e hijos de padres/madres heterosexuales, en ningún caso, arrojaba diferencias significativas. En lo relativo al autoconcepto y a la autoestima, entre muchos otros, son varios los que no encuentran diferencias significativas: Golombok, Spencer y Rutter (1983); Patterson (1992) y Fitzgerald (1999). En lo concerniente a los trastornos de conducta, entre unos hijos y otros, no resultan diferencias significativas: Green, Mandel, Hotvedt, Gray y Smith (1986); Kleber, Howell y Tibbits-Kleber (1986); Gibbs (1988); Fitzgerald (1999).

Un avance de los resultados globales del primer estudio, realizado en Francia por estas fechas, sobre una muestra de 58 niños criados por padres homosexuales, discurre en esta dirección. La autora, Nadaud (2002: 302), indica: "No se trata pues de afirmar que todos los niños de padres homosexuales van bien, sino de aportar una piedra suplementaria al edificio de los estudios que ya muestran que los comportamientos corresponden a los de otros niños de su edad".

Estos resultados cosechados por las investigaciones iniciales, con lógicas mejoras metodológicas, siguen encontrando apoyo en los estudios actuales. En lo relacionado con el ajuste psicológico de estos hijos e hijas, por problemas asociados con un desarrollo adecuado de la autoestima y con un mayor peligro de desarrollar trastornos de naturaleza emocional y/o comportamental, resulta muy relevante un estudio, publicado en EE. UU., por Gartrel y Bos (2010). Los resultados encontrados, en contraste con los datos poblacionales disponibles, llegan incluso a destacar, ciertas diferencias significativas de lado de niños y niñas de madres lesbianas. Es decir, mayores puntuaciones en competencias social y académica, así como menores niveles en problemas sociales y agresividad. También Bos y Sandfort (2010), y las autoras Golombok y Badger (2010), en un estudio longitudinal, contrastan el ajuste psicológico de jóvenes adultos criados, desde el nacimiento, con madres lesbianas solas, con otros jóvenes adultos criados en un grupo familias de madres solas heterosexuales y, otros, criados en familias heteroparentales biparentales. Tanto los jóvenes criados 
por madres solas heterosexuales, como los criados por madres lesbianas, obtuvieron mejores puntuaciones en las medidas de depresión, ansiedad y hostilidad, que los criados en familias heteroparentales biparentales. Más recientemente Cenegy, Denney y Kimbro (2018) también han presentado un trabajo, cuyas principales conclusiones sugieren que una peor o mejor salud mental entre los niños de parejas del mismo sexo, parejas de diferentes sexos y familias monoparentales parece ser en gran medida consecuencia de las diferencias demográficas y socioeconómicas en lugar de la exposición a formas familiares no tradicionales.

En lo que respecta al "riesgo" o preocupación de que los hijos de padres gays o madres lesbianas puedan seguir la orientación sexual de sus padres, con mayor probabilidad que los criados por padres heterosexuales, son bastantes los resultados que desmienten esta probabilidad. Así, en un estudio a cargo de Goldberg (2010) y otro de naturaleza longitudinal, realizado por Golombok y Badger (2010), se concluye que una gran mayoría de los integrantes de muestras de niños/niñas con padres/madres homosexuales, dicen sentirse heterosexuales. En esta dirección se pronuncian Gartrell, Boss y Goldberg (2012), según una muestra de jóvenes adolescentes, criados por gays o lesbianas.

También en España, los todavía pocos estudios sobre homoparentalidad, han venido aportando resultados en el mismo sentido. Así, las conclusiones del primer estudio, a cargo de González et al. (2002), alertan de que no pueden establecerse distinciones apreciables en capacidades, ni en desarrollo personal y afectivo entre los niños y niñas criados en familias homoparentales y los niños crecidos en el seno de familias heteroparentales. Se subraya, en cualquier caso, una mayor apertura de aquellos menores a la hora de considerar los roles de género y las distintas opciones de orientación sexual.

En cuanto al ajuste psicológico de niños y niñas de padres gays o madres lesbianas, en comparación con los hijos e hijas de padres o madres heterosexuales, González et al. (2005) recogen normalidad en la medida de la autoestima, ajuste emocional y conductual. También Oliva y Arranz (2010), encontraron patrones de normalidad en ajuste psicológico en los menores estudiados en familias homoparentales similares a los manifestados en otras organizaciones familiares. Otras investigaciones, igualmente, entre las más recientes las de Amat y Moliner (2017) y Neto (2017), han constatado que el grado de apoyo social percibido por las familias homoparentales no se diferencia significativamente del manifestado por las heterosexuales. También, estos padres y madres se muestran altamente satisfechos con el apoyo emocional e instrumental prestado por las personas consideradas muy importantes en sus vidas cotidianas (González y Sánchez, 2003). 
En definitiva, lógicamente, cuando se toma una determinada decisión, el niño se convierte en sujeto único de derecho. Por ello lo fundamental estribaría ahora, no tanto en factores relacionados con la concepción de la familia y las funciones a desempeñar por los distintos padres o madres, sino en la capacidad de tolerancia, flexibilidad, control emocional, etc., que en realidad constituyen los basamentos imprescindibles para la debida crianza y atención a los niños.

\section{MÉTODO}

Para el desarrollo del presente estudio se ha utilizado un diseño descriptivo, con mayor precisión un estudio de encuesta, cuyos principales objetivos de investigación son, por una parte, determinar la opinión que una muestra de alumnado perteneciente a diferentes titulaciones de las Facultades de Ciencias de la Educación de la Universidad Granada han mostrado sobre la homoparentalidad como modalidad familiar y, por otra, comprobar si existen, o no, diferencias estadísticamente significativas al cruzar dicha opinión con las diversas titulaciones, géneros, ámbitos de nacimiento, así como si conoce o no a parejas homoparentales de cara a establecer un perfil característico de los estudiantes con mejor o peor actitud hacia dichas parejas homoparentales.

\subsection{Variables de la investigación}

Contemplamos dos tipos de variables en nuestro estudio. En primer lugar, las variables independientes con carácter meramente atributivo y no experimental entre las que se encuentran:

a) Género: hombre vs mujer.

b) Titulación: Grado de Educación Social, Infantil, Primaria y Pedagogía.

c) Si conoce o no algún caso de pareja homoparental.

d) Ámbito de nacimiento: rural vs urbano.

En segundo lugar contemplamos las variables criterio, o sea, cada uno de los 20 ítems que conforman la escala de opinión hacia familias homoparentales.

\subsection{Recogida de información}

\subsubsection{Muestra, características muestrales y proceso de muestreo}

El tamaño muestral asciende a 332 estudiantes que han sido seleccionados mediante muestreo probabilístico estratificado que ha tomado como estrato único a la titulación. El procedimiento de determinación de tamaño muestral parte de una población de aproximadamente 6000 estudiantes, un nivel de 
confianza de 0.95 y un error muestral de $\pm 5 \%$ con probabilidades desconocidas $\mathrm{p}=\mathrm{q}=0.5$. En cuanto a las características muestrales la edad media de los estudiantes se sitúa en 20,03 años con una desviación típica de 3,69, correspondiendo el $19 \%$ a hombres y el $81 \%$ restante a mujeres. En cuanto al ámbito de nacimiento el 39,2\% nacieron en un ámbito rural y el 60,8\% en urbano. También el 37,7\% no conocen ningún caso de familias homoparentales, mientras el 62,3\% sí. Finalmente y por lo que respecta a la titulación que cursan, el 23,8\% corresponden al Grado de Educación Social, el 36,9\% al de Primaria, el 26,8\% al de Infantil y el 17,5\% restante al de Pedagogía.

\subsubsection{Instrumento de recogida de información}

Para la recogida de información se ha utilizado una adaptación de la escala de Actitud hacia las Familias Homoparentales (AHFH) de Ramírez, Moliner y Vicent (2008) que consta de 20 ítems en formato Likert con cinco respuestas posibles que van desde 1: nunca/muy en desacuerdo hasta 5 : siempre/muy de acuerdo. Por nuestra pare hemos incluido 5 variables de identificación que actúan como variables de agrupación para denotar futuras comparaciones. Estas variables son edad, género, titulación, ámbito de nacimiento y si conocen o no familias homoparentales.

\subsection{Parámetros de calidad de la escala AHFM}

Como parámetros de calidad de la escala AHFM hemos contemplado la fiabilidad y la validez. Del primero, la fiabilidad como consistencia interna, dado que sólo disponemos de una sola administración. Para ello hemos calculado el coeficiente de fiabilidad de $\alpha$ de Cronbach que ha arrojado un valor $\alpha=0,81$. En consecuencia, podemos afirmar que la escala AHFM administrada a nuestra muestra es consiste y estable y que los diferentes ítems que la conformar, al estar muy correlacionados entre sí, garantizan de forma convincente que están midiendo la misma variable latente.

Del segundo parámetro, la validez contemplamos la validez de contenido o grado en que los ítems que conforman la escala miden realmente el constructo para el cual han sido elaborados. Para su garantización hemos tomado una escala ya elaborada y utilizada en una investigación anterior (consultar apartado inmediatamente anterior). También hemos contemplado la validez criterial concurrente. Para ello hemos calculado la correlación ítem-total corregida, es decir, la correlación de cada ítem individualmente con el total de prueba (como criterio interno) menos el ítem en cuestión. En todos los casos, se han conseguido coeficientes de correlación $\mathrm{r}>0.35$, razón por la cual podemos afirmar que cada ítem mide individualmente lo que el conjunto de la escala (univocidad). 


\section{ANÁLISIS Y DISCUSIÓN DE DATOS}

Para el análisis de la información recolectada mediante la escala descrita anteriormente hemos utilizado el programa de análisis de datos cuantitativos SPSS v.24. Hemos implementado análisis de naturaleza descriptiva, inferencial y multivariante para el cumplimiento del fundamental objetivo de investigación planteado. Como procedimiento previo a cualquier tipo de análisis hemos recodificado los ítems inversos y, además, hemos creado una nueva variable de tipo dummy conformada por el sumatorio promedio de los 20 items que nos ha servido como medida global de la variable dependiente opinión sobre las familias homoparentales. Presentamos a continuación los resultados obtenidos comparativamente por variables de identificación (variables independientes atributivas) contempladas (sexo, ámbito de nacimiento, titulación y si conoce o no alguna familia homoparental). Hemos descartado la variable edad, dado que más del $90 \%$ de la muestra se concentraba entre los 18 y los 21 años, con lo cual no hay la heterogeneidad necesaria para denotar efectos diferenciales.

Como se deduce de la observación de esta primera tabla, el primer aspecto destacable es la buena opinión que han mostrado los estudiantes objeto de estudio acerca de las familias homoparentales como nueva forma de estructura familiar. Ello es así, porque dado que los ítems están conformados por respuestas de 1 a 5 , donde el 1 es el mínimo acuerdo y 5 el máximo acuerdo, ninguna media aritmética es menor de 4 , según se puede observar en los niveles disgregados de cada una de las variables independientes contempladas (de naturaleza atributiva).

Otro aspecto diferente, es la intensidad con que se ha valorado la opinión hacia las familias homoparentales por cada uno de dichos niveles que conforman las cuatro variables atributivas contempladas. Aquí sí que podemos apreciar, a priori, diferencias sensibles, entre hombres frente a mujeres, entre conocimiento o no de parejas homoparentales, entre las diferentes titulaciones objeto de estudio, etc. De hecho, para determinar si estas diferencias son, o no, estadísticamente significativas $(p<0.05)$ se han implementado dos pruebas de significación de naturaleza no paramétrica (U Mann. Whitney cuando son dos los niveles a comparar y el ANOVA unifactoral de Kruskal-Wallis cuando han sido más de dos los niveles a comparar) ante el incumplimiento de los supuestos paramétricos y el sesgo que podría conllevar su cálculo e interpretación.

Los resultados obtenidos muestran que, en efecto, tres de las cuatro variables contempladas marcan diferencias estadísticamente significativas entre sus diferentes niveles. Estas variables son el género $(p<0.05)$, donde la mayor media es para las mujeres $(4,29)$, el conocimiento o no de una familia homoparental $(p<0.001)$, donde la media superior ha sido para los que sí conocen familias homoparentales $(4,29)$ y la titulación que cursan los estudiantes $(p<0.001)$, 
Tabla Medias del total de prueba por variables atributivas contempladas

\begin{tabular}{|c|c|c|}
\hline Sexo & Media & Sig. Est ${ }^{\mathrm{i}}$. \\
\hline Hombre & 4,03 & \multirow{3}{*}{$0.030 *$} \\
\hline Mujer & 4,29 & \\
\hline Total & 4,24 & \\
\hline Ámbito de nacimiento & Media & Sig. Est ${ }^{\mathrm{i}}$. \\
\hline Rural & 4,27 & \multirow{3}{*}{0.356} \\
\hline Urbano & 4,23 & \\
\hline Total & 4,24 & \\
\hline Conoce a una pareja homoparental? & Media & Sig. Est'. \\
\hline No & 4,15 & \multirow{3}{*}{$0.001 * * *$} \\
\hline $\mathrm{Si}$ & 4,29 & \\
\hline Total & 4,24 & \\
\hline Titulación & Media & Sig. Est ${ }^{\mathrm{ii}}$. \\
\hline Educación Social & 4,36 & \multirow{5}{*}{$0.001 * * *$} \\
\hline Educación Primaria & 4,26 & \\
\hline Educación Infantil & 4,21 & \\
\hline Pedagogía & 4,09 & \\
\hline Total & 4,24 & \\
\hline
\end{tabular}

i Prueba U-Mann-Whitney para dos muestras independientes.

ii Prueba de ANOVA unifactorial de Kruskal-Wallis para K muestras independientes.

Diferencias estadísticamente significativas: ${ }^{*}<0.05^{* *}<0.01^{* * *}<0.001$

donde la media más grande ha correspondido al Grado de Educación Social $(4,36)$. Por el contrario, la pertenencia de los mismos a ámbitos rural o urbano no ha marcado diferencia alguna $(p>0.05)$, si bien hay una ligera superioridad del alumnado de ámbito rural frente al urbano. En este contexto, donde conocemos que tres de las cuatro variables atributivas sí que marcan opiniones diferenciales resulta conveniente implementar una técnica multivariante que se sea capaz de conformar perfiles diferenciales que sean útiles para discernir 
qué rasgos caracterizan a los estudiantes que están muy de acuerdo con las familias homoparentales, de aquellos que lo están en menor medida, pero que al fin y al cabo, también muestran un moderado acuerdo con las familias homoparentales como estructura familiar.

Para ello hemos decidido implementar una técnica de segmentación denominada árboles de decisión mediante el método CHAID (Chi-square automatic interaction detector). En esencia, como indican Berlanga, Rubio y Vilá (2013: 65) un árbol de decisiones es una técnica estadística para la segmentación, la estratificación, la predicción, la reducción de datos y el filtrado de variables, la identificación de interacciones, la fusión de categorías y la discretización de variables continuas, en búsqueda de un perfil característico, añadimos nosotros.

En cuanto al método CHAID debemos destacar que permite crear perfiles a partir la comparación de los niveles de las variables consideradas predictoras y su interacción con la variable considerada criterio o dependiente. Dichos niveles de cada predictor se funden si no son significativamente distintos respecto a la variable criterio de tal forma, que se van creando nodos por variables de manera jerárquica, de tal forma que las primeras variables son mejores predictores que las que aparecen con posterioridad.

En el presente trabajo al contemplar como variable criterio una variable cuantitativa (total prueba promedio) no utilizaremos la prueba de chi cuadrado, sino la razón entre la media cuadrática entre e intra (F) con su grado de significación correspondiente. Los principales resultados obtenidos a este respecto son los siguientes.

Tabla 1. Resumen del modelo

\begin{tabular}{l|l|l}
\hline Especificaciones & Método de crecimiento & CHAID \\
\hline & Variable dependiente & TOTAL_PRUEBA PROMEDIADA \\
\hline & Variables independientes & $\begin{array}{l}\text { sexo, Ámbito de nacimiento, Conoce a una } \\
\text { pareja homoparental?, TITULACIÓN }\end{array}$ \\
\hline & Validación & Validación cruzada \\
\hline & Máxima profundidad del árbol & 3 \\
\hline Resultados & Casos mínimos en nodo padre & 100 \\
\hline & Casos mínimos en nodo hijo & 50 \\
\hline & $\begin{array}{l}\text { Variables independientes } \\
\text { incluidas }\end{array}$ & $\begin{array}{l}\text { sexo, TITULACIÓN, Conoce a una pareja } \\
\text { homoparental? }\end{array}$ \\
\hline & Número de nodos & 7 \\
\hline & Número de nodos terminales & 4 \\
\hline & Profundidad & 3 \\
\hline
\end{tabular}


En la tabla inmediatamente anterior pueden apreciarse las especificaciones del modelo implementado. También los resultados del mismo donde la principal consideración a tener en cuenta es la eliminación de la variable ámbito de nacimiento como predictor de la opinión global sobre parejas homoparentales. A continuación mostramos el diagrama de árbol resultante.

Gráfico 1. Diagrama de árbol para la opinión sobre familias homoparentales de los estudiantes de la Facultad de Ciencias de la Educación de la Universidad de Granada

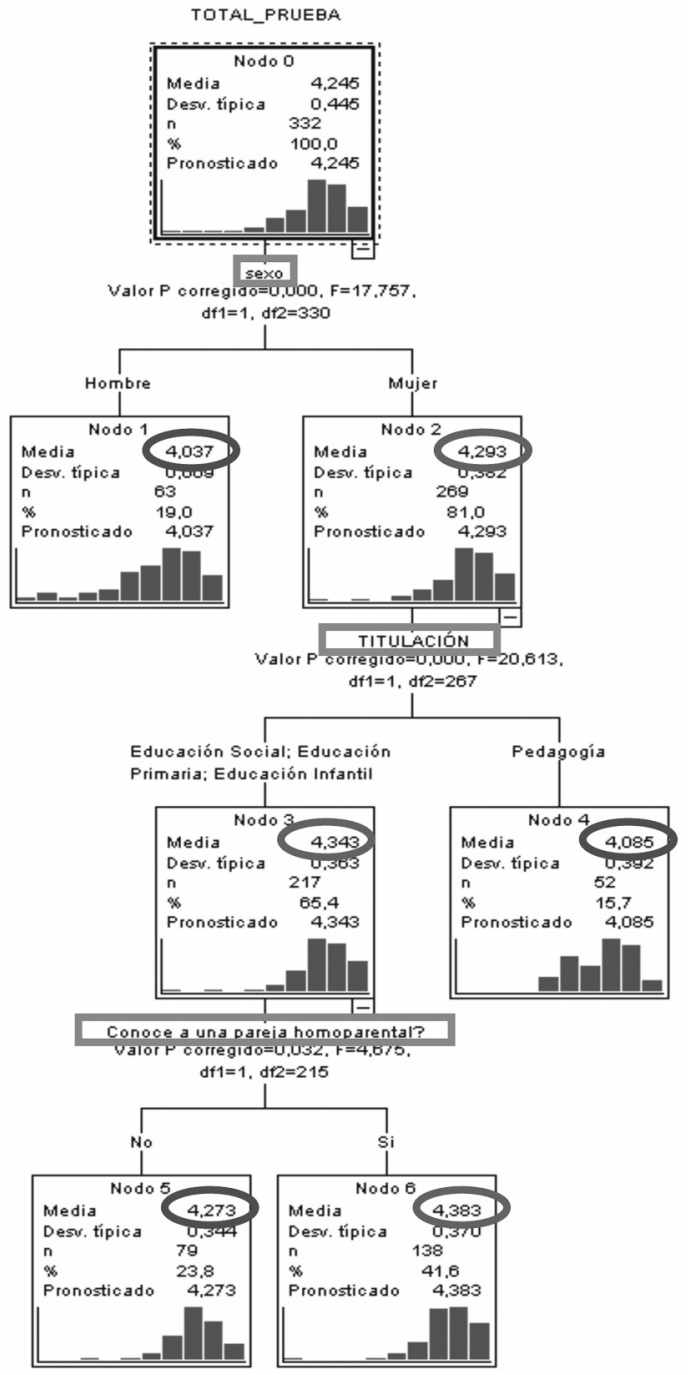


Como podemos apreciar el árbol de decisiones ha creado hasta 6 nodos. En el nodo 0 se sitúa la variable dependiente opinión hacia las familias homoparentales y en el mismo pueden apreciarse los estadísticos descriptivos básicos (media real y pronosticada y la desviación típica, así como el tamaño muestral). En los nodos 1 y 2 puede apreciarse la primera variable de mayor poder predictivo que ha inferido la técnica CHAID. En este caso, encontramos la variable sexo en la que puede apreciarse en azul la media de las mujeres $(\mathrm{M}=$ $4,29)$ superior a la de los hombres $(M=4,03)$ en rojo. La prueba de significación para denotar diferencias entre dichas medias (nodos) ha arrojado un valor $F(1,330)=17,75, p=0.000$, es decir, que hay diferencias estadísticamente significativas en favor de las mujeres. En los nodos 3 y 4 , por su parte, se representa la variable predictiva titulación. Es la segunda variable pronóstico en importancia y puede apreciarse como el nodo 3 (en azul) está conformado por todas las titulaciones participantes en el estudio $(M=4,29)$, menos el Grado de Pedagogía $(M=4,08)$ que se sitúa en solitario en el nodo 4 (en rojo). La prueba de significación para tratar de determinar si entre dichas medias (nodos) existen o no diferencias ha arrojado un valor $F(1,267)=20,61, p=0.000$, es decir, que hay diferencias estadísticamente significativas en favor de todas las titulaciones con respecto al Grado de Pedagogía. Por último encontramos los nodos 5 y 6 conformados por la variable conocimiento o no de una pareja homoparental. En este caso, dicha variable podría ser considerada como la tercera variable predictiva en importancia. El nodo 5 (en rojo) corresponde a los estudiantes que no conocen familias homoparentales $(M=4,27)$ menor que la obtenida por aquellos que sí conocen familias homoparentales (nodo 6, en azul) con una $(M=4,38)$. La prueba de significación para tratar de determinar si entre dichas medias (nodos) existen o no diferencias ha arrojado un valor $\mathrm{F}(1,215)$ $=4,87, \mathrm{p}=0.032$, es decir, que hay diferencias estadísticamente significativas en favor de los que sí conocen familias homoparentales, frente a los estudiantes que no las conocen.

Otro aspecto decisivo de la técnica CHAID es conocer el grado de ajuste o precisión del mismo a la hora de predecir los perfiles de estudiantes que muestran un mayor acuerdo o un acuerdo moderado con las parejas homoparentales como nueva estructura familiar. A este respecto el modelo ha calculado el llamado riesgo con una estimación de 0,17 asociado a una error estándar de 0,024 . Para apreciar con mayor entendimiento estos resultados debemos destacar que el modelo predictivo posee un error del $17 \%$ y, en consecuencia, una precisión predictiva del 83\% con un error típico realmente bajo. 


\section{CONCLUSIONES}

Queda constatada, por razones obvias, la existencia y permanencia histórica de la institución familiar. Pero esta situación, como vemos, no ha impedido importantes cambios en su estructura o configuración familiar. De modo que, en la actualidad, junto al modelo de familia tradicional, se constatan otras formas diversas de organización familiar. Entre ellas, la familia homoparental, siguiendo distintas formas de acceso, resulta, obviamente, especialmente novedosa. Y es que, la interpretación de la Constitución Española de 1978 y el Derecho de Familia, han posibilitado, al igual que en otros países, que incluso el matrimonio entre personas que comparten una misma orientación sexual, puedan, desde el año 2005, contraer matrimonio. Las reticencias observadas, en torno a la idoneidad de estas familias para cumplir con sus funciones básicas y el adecuado desarrollo de la personalidad y conducta de los hijos, han sido rechazadas. Todo ello, de conformidad con los resultados cosechados por el conjunto de investigaciones nacionales e internacionales, que no vienen encontrando diferencias significativas entre las familias heteroparentales y homoparentales en aquellas dimensiones consideradas más trascendentales.

Otra de las consideraciones que hemos de mencionar, con respecto al análisis de los datos realizado a la muestra de estudiantes que han participado en el estudio, es la de señalar su opinión globalmente favorable acerca de las familias homoparentales, como constata las presencia de medias aritméticas iguales o superiores a 4 (continuum de 1 a 5 ) y obtenidas en todos los niveles que conforman las distintas variables de perfil establecidas, es decir, sexo, titulación, conocimiento o no de una pareja homoparental, así como la procedencia rural o urbana.

Por otra parte, y con el objetivo de establecer perfiles de alumnado, destacamos los posibles efectos diferenciales (estadísticamente significativos) entre los distintos niveles que conforman las variables de identificación contempladas. Así en cuanto a la variable sexo, constatamos que las mujeres valoran mejor que los hombres a las familias homoparentales, sin menoscabo de que la opinión de los hombres sea también favorable. También confirmamos que aquellos estudiantes que conocen a parejas homoparentales valoran mejor a las familias homoparentales que aquellos que no las conocen, aunque ello no signifique, igual que en el caso del sexo, que aquellos estudiantes que las conocen no tengan una buena valoración de las familias homoparentajes. En cuanto a las titulaciones que han participado en esta investigación (Grado en Educación Infantil, Grado en Educación Social, Grado en Pedagogía y Grado en Educación Primaria), se constata que es el grado de Pedagogía el que ha mostrado un menor acuerdo con las familias homoparentales, aunque como en los dos casos 
anteriores, su valoración se mantenga por encima de 4 y, por tanto, pueda considerarse como moderadamente importante. Caso totalmente opuesto ha sido es del ámbito de nacimiento de los estudiantes. En este caso particular no se han producido diferencias estadísticamente significativas entre el ámbito rural vs urbano. Ello significa, por consiguiente, que el alumnado de procedencia rural y urbano valoran de forma parecida a las familias homoparentales. En cualquier caso, dicha valoración puede considerarse muy favorable a las familias homoparentales.

Precisamente la presencia de diferencias estadísticamente significativas entre los distintos niveles de las variables identificativas justifica el desarrollo de una técnica de análisis multivariante capaz de establecer perfiles a partir de la división de un "árbol" en nodos. Esa técnica no es otra que la técnica CHAID. Una vez implementada se ha constatado la presencia de dos perfiles bien diferenciados:

a) El alumnado que está moderadamente a favor de las familias homoparentales que estaría conformado, fundamentalmente, por hombres del Grado de Pedagogía que no conocen parejas homoparentales y que proceden indistintamente de los ámbitos rurales y urbanos.

b) El alumnado que se muestra muy a favor de las familias homoparentales que estaría constituido, en esencia, por mujeres de todos los grados objeto de investigación, menos el Grado de Pedagogía, que sí conocen parejas homoparentales y que proceden, del mismo modo, indistintamente de los ámbitos rurales y urbanos.

\section{BIBLIOGRAFÍA}

Alberdi, I. (1995). Informe sobre la situación de la familia en España. Madrid: Ministerio de Asuntos Sociales, Centro de Publicaciones.

Alberdi, I. (1999). La nueva familia española. Madrid: Taurus.

Amat, F. y Moliner. L. (2017). "Me aconsejaron o casi me obligaron a ser 'normal'. Análisis de las barreras de exclusión a partir de historias de vida de mujeres lesbianas y bisexuales". OBETS. Revista de Ciencias Sociales, 12(1): 41-59.

doi:10.14198/OBETS2017.12.1.02

Arranz, E. y Oliva, A. (2010). Desarrollo psicológico en las nuevas estructuras familiares. Madrid: Pirámide.

Berger, B. y Berger, P. L. (1983). The war over the family: Capturing the middle ground. London: Hutchinson.

Bos, H. y Sandfort, T. G. (2010). "Children's gender identity in lesbian and heterosexual two-parent families". Sex Roles, 62(1-2), 114-126.

Brewaeys, A. Ponjaert, I., Van Hall, E. V. y Golombok, S. (1997). "Donor insemination: child development and family functioning in lesbian mother families". Human Reproduction, 12(6), 1349-1359. 
Cenegy, L.F; Denney, J. T. \& Kimbro, R.T. (2018). "Family Diversity and Child Health: Where Do Same-Sex Couple Families Fit?" .Journal of Marriage and Family, 80(1), 198-218.

CIS (2004). Opiniones y actitudes sobre la familia. Estudio número 2.578 (OctubreNoviembre). Recuperado de http://www.cis.es/cis/export/sites/default/-Archivos/Mar ginales/2560_2579/2578/Es2578.pdf

Comisión de Derechos Humanos. Declaración Universal de los Derechos Humanos de 1948. Descargado de: http://www.un.org/es/universal-declaration-human-rights/

Cortina, C. y Cabré, A. (2010). "Las uniones homosexuales en España. Una caracterización sociodemográfica a partir del censo de 2001". Papers: revista de sociologia, 95(3), 565-583.

Cramer, D. (1986). "Gay parents and their children: A review of research and practical implications". Journal of Counseling E Development, 64(8), 504-507.

Del Campo, S. (1982). La evolución de la familia española en el siglo XX, Madrid: Alianza.

Delaunay, C. (2018)."Mapping socio-technical controversies about same-sex couples access to assisted reproductive technologies in France and Portugal". Salute e Societa, 17 (2), 72-89.

Díaz, V. P. Chuliá, E. y Fernández, C. V. (2000). La familia española en el año 2000: innovación y respuesta de las familias a sus condiciones económicas, políticas y culturales (Vol. 16). Madrid: Fundación Argentaria.

Espíng-Andersen, G. (2013). (Coord.). El déficit de natalidad en Europa. La singularidad del caso español. Barcelona: Fundación BBVA

Falk, P. J. (1994). "The gap between psychosocial assumptions and empirical research in lesbian-mother child custody cases”. In Redefining families (pp. 131-156). Springer US.

Farr, R. H. (2017). "Does parental sexual orientation matter? A longitudinal follow-up of adoptive families with school-age children". Developmental Psychology, 53(2), 252264.

Fitzgerald, B. (1999). "Children of lesbian and gay parents: A review of the literature." Marriage \& Family Review, 29(1), 57-75.

Frías Navarro, D. Pascual, J. y Monterde Bort, H. (2003). "Familia y diversidad: hijos de padres homosexuales". En: IV congreso virtual de Psiquiatria. Recuperado: http://www.interpsiquis.com/2003.

Fundación Adecco (2012). II Informe mujer con responsabilidades familiares no compartidas y empleo. Descargado de: http://www.west-info.eu/in-spain-a-default-leadsto-another/informe-3...

Gahan, L. (2018). "Separated Same-Sex Parents: Troubling the Same-Sex Parented Family". Sociological Research Online, v.23(1), 245-261.

Gartrell, N. K. Bos, H. M. y Goldberg, N. G. (2012). "New trends in same-sex sexual contact for American adolescents?" Archives of sexual behavior, 41(1), 5-7.

Gartrell, N., y Bos, H. (2010). "US National Longitudinal Lesbian Family Study: psychological adjustment of 17-year-old adolescents". Pediatrics, 126(1), 28-36. 
Gates, G. J. (2015). "Marriage and family: LGBT individuals and same-sex couples". Future of Children, 25(2), 67-87.

Gibbs, E. D. (1989). "Psychosocial development of children raised by lesbian mothers: A review of research". Women \& Therapy, 8(1-2), 65-75.

Gilgoff, D. (02-12-2004). "Hijos de un solo sexo". El País, pp. 5.

Goldberg, A. E. (2010). Lesbian and gay parents and their children: Research on the family life cycle. Universidad de Michigan: American Psychological Association.

Golombok, S. Spencer, A. y Rutter, M. (1983). "Children in lesbian and single parent households: Psychosexual and psychiatric appraisal”. Journal of Child Psychology and psychiatry, 24(4), 551-572.

Golombok, S. y Badger, S. (2010). "Children raised in mother-headed families from infancy: a follow-up of children of lesbian and single heterosexual mothers, at early adulthood". Human Reproduction, 25(1), 150-157.

Golombok, S. y Tasker, F. (1996). "Do parents influence the sexual orientation of their children? Findings from a longitudinal study of lesbian families". Developmental psychology, 32(1), 3.

González, M. M. (2005). Homosexualidad y adopción. Entre la ciencia y el prejuicio. INFOCOP, 24, 16-19.

González, M. M. Morcillo, E. Sánchez, M. Á. Chacón, F. y Gómez, A. (2004). “Ajuste psicológico e integración social en hijos e hijas de familias homoparentales". Infancia y aprendizaje, 27(3), 327-343.

González, M. M. y Sánchez, M. (2003). "Las familias homoparentales y sus redes de apoyo social". Portularia: Revista de Trabajo Social (Vol. 3, p. 207-220).

González, M. M., Chacón, F. Gómez, A. Sánchez, M. A. y Morcillo, E. (2002). "Dinámicas familiares, organización de la vida cotidiana y desarrollo infantil y adolescente en familias homoparentales". En Estudios e investigaciones 2002 (pp. 521-606). Madrid: Oficina del Defensor del Menor de la Comunidad de Madrid.

Gottman, J. S. (1989). "Children of gay and lesbian parents". Marriage E Family Review, 14 (3-4), 177-196.

Green, G. D. y Bozett, F. W. (1991). "Lesbian mothers and gay fathers". In J. C. Gonsiorek y J. D. Weinrich (Eds.), Homosexuality: Research implications for public policy (p. 197-214). Newbury Park, CA: Sage.

Green, R. Mandel, J. B. Hotvedt, M. E. Gray, J. y Smith, L. (1986). "Lesbian mothers and their children: A comparison with solo parent heterosexual mothers and their children". Archives of sexual behavior, 15(2), 167-184.

Herrero Brasas, J. A. (1993). "La sociedad gay: una invisible minoría". Claves de Razón Práctica, (37), 26-42.

Hotvedt, M. E. y Mandel, J. B. (1982). "Children of lesbian mothers". En: Homosexuality: Social, psychological, and biological issues, 275-285.

Huggins, S. L. (1989). "A comparative study of self-esteem of adolescent children of divorced lesbian mothers and divorced heterosexual mothers". Journal of homosexuality, 18 (1-2), 123-135. 
Juárez Mendez, A.J. Chávez Intriago, M.Y. (2016). "La experiencia de ser familia en una pareja homosexual" Revista Publicando, 3(7). 2016, 69-89.

Jurado, T. (2005). "Las nuevas familias españolas". En J.J. González y M. Requena (eds.). Tres décadas de cambio social en España. Madrid: Alianza.

Kleber, D. J. Howell, R. J. y Tibbits-Kleber, A. L. (1986). "The impact of parental homosexuality in child custody cases: A review of the literature". Bulletin of the American Academy of Psychiatry and Law, 14(1), 81-87.

Machin, R. (2016). "Homoparenthood and adoption: (re)affirming its place as family". Psicologia e Sociedade, 28 (2)350-359.

Meil, G. (1999). La postmodernización de la familia española. Madrid: Acento.

Montes, A. González, M. López-Gaviño, F. y Angulo, A. (2016). "Familias homoparentales, más visibles y mejor aceptadas: efectos del matrimonio en España". Apuntes de Psicología, 34(2-3), 151-159.

Nadaud, S. (2002). Homoparentalité. Une nouvelle chance pour la famille? París: Fayard.

Navarro, F. Pascual Llobell, J. y Monterde Bort, H. (2004, Febrero). Hijos de padres homosexuales: qué les diferencia. En Ponencia presentada en el V Congreso Virtual de Psiquiatría. Recuperado de http://www. felgt. org/files/docs/7e65bee1c39e. pdf.

Neto, P.P.B. y Pedrosa, M.I. (2017). "Children's meaning-making process about gay families". Arquivos Brasileiros de Psicologia, 69 (3), 21-35.

Ocobock, A. (2018). "Status or Access? The Impact of Marriage on Lesbian, Gay, Bisexual, and Queer Community Change". Journal of Marriage and Family, v.80(2), 367382.

Ocón J. (2013). Fundamentos de Sociología. Granada: Gami.

Ocón, J. (2002). "Reflexiones en torno a la adopción por parejas homosexuales". Cuadernos de Trabajo Social, 15, 93-114.

Oliva Delgado, A. y Arranaz, E. (2010). Nuevas familias y bienestar infantil. Vol. 2. Sevilla: Universidad de Sevilla.

Palau, C. M. L. (2016). "La Reforma del Matrimonio Civil en España". Avances, 11(13), 13.

Patterson, C. J. (1992). "Children of lesbian and gay parents". Child development, 63(5), 1025-1042.

Patterson, C. J. (1997). "Children of lesbian and gay parents." Advances in clinical child psychology (pp. 235-282). Springer US.

Perales, F. (2018). "The cognitive roots of prejudice towards same-sex couples: An analysis of an Australian national sample". Intelligence, 68, 117-127.

Placeres Hernández, J. F., Olver Moncayo, D. H., Rosero Mora, G. M., Urgilés Calero, R. \& Abdala-Jalil Barbadillo, S. (2017). "La familia homoparental en la realidad y la diversidad familiar actual". Revista Médica Electrónica, 39(2), 361-369.

Ramírez, S. Moliner, V. y Vicent, L. (2006). "Actitudes frente a las familias homoparentales en el contexto escolar". Fòrum de Recerca, 12, 1-23.

Rodríguez, L. (2018). "La adopción homoparental en Colombia: consideraciones conceptuales y jurisprudenciales". Inciso, 19(2), 1-16. 
Sánchez Díaz, S., Podestá González, S. P., Garrido, P. (2018). "Ser madre fuera de la heteronormatividad: Trayectorias vitales y desafíos de familias homoparentales chilenas". Psicoperspectivas. Individuo y Sociedad, 17(1), 1-10.

Soriano G. (1978). Homosexualidad y represión. Madrid: Zero Zix.

Steckel, A. (1987). Psychosocial development of children of lesbian mothers. In F. W. Bozett (Ed.), Gay and lesbian parents (pp. 75-85). New York: Praeger.

Van de Kaa, D. J. (1987). "Europe's second demographic transition". Population bulletin, 42(1), 1-59.

VV.AA. (Ed.) Agencia Estatal Boletín Oficial del Estado. (2008) Boletín Oficial del Estado, núm. 157, de 2 de julio de 2005.

\section{BREVES NOTAS BIOGRÁFICAS}

JOSÉ OCÓN-DOMINGO. Licenciado en Sociología. Profesor titular del Departamento de Sociología y Ciencias Políticas de la Universidad de Granada. Imparte asignaturas de Fundamentos de la Sociología y Técnicas de Investigación Social en los Grados de Sociología y Educación Social. Correo electrónico. joseocon@ugr.es

CLEMENTE RODRÍGUEZ-SABIOTE. Licenciado en Pedagogía y Diplomado en Trabajo Social. Profesor titular del Departamento de Métodos de Investigación y Diagnóstico en Educación de la Universidad de Granada. Imparte asignaturas de metodología de la investigación en los Grados de Pedagogía y Educación Social.

Correo electrónico: clerosa@ugr.es

Código ORCID: https://orcid.org/0000-0003-3094-9199

DANIEL ÁLVAREZ-FERRÁNDIZ. Alumno del Grado de Primaria de la Universidad de Granada. Coautor de numerosos trabajos presentados en Congresos Internacionales, así como de algunos artículos publicados en revistas científicas. Correo electrónico: ferrandiz98@correo.ugr.es

Recibido: 05-11-2017

Aceptado: 18-06-2018

(C) (7) Licencia Creative Commons Reconocimiento (CC BY 4.0) 



\title{
ANÁLISIS DEL DESEMPEÑO OCUPACIONAL DE LAS PERSONAS EN SITUACIÓN DE DESALOJO EN LA CIUDAD DE A CORUÑA (GALICIA-ESPAÑA) ANALYS OF THE OCCUPATIONAL PERFORMANCE OF PEOPLE IN SITUATIONS OF EVICTION IN THE CITY OF A CORUÑA. (GALICIA. SPAIN)
}

\author{
Irene Pazos-Carro \\ Residencia Geriátrica "O Fogar de Gandarío" \\ irenepazos1@hotmail.com \\ Ana-Isabel Souto-Gómez \\ Federación Galega de Esclerose Múltiple (FEGADEM), España \\ anasogo@hotmail.es \\ Miguel-Ángel Talavera-Valverde \\ Universidade da Coruña, España \\ miguel.angel.talavera.valverde@udc.es
}

\section{Cómo citar / citation}

Pazos-Carro, I., Souto-Gómez, AI. y Talavera-Valverde, MA. (2018) "Análisis del desempeño ocupacional de las personas en situación de desalojo en la ciudad de A Coruña (Galicia-España)". OBETS. Revista de Ciencias Sociales, 13(2): 593-620. doi: 10.14198/OBETS2018.13.2.06

\section{Resumen}

Introducción: la crisis global tiene impacto en numerosos hogares debido al desempleo de sus integrantes propiciando desalojos de vivienda por impagos. Esto repercute en la salud y en el desempeño ocupacional de individuos-comunidades. Método: se realizó un estudio cualitativo fenomenológico en A Coruña (Galicia/España), cuyo fin pretendía realizar una aproximación al constructo vivencial del desempeño ocupacional de estas personas. Resultados: se evidencian modificaciones del desempeño ocupacional y de la salud, resultante de las vivencias experimentadas. Conclusión: el constructo vivencial de 
desempeño ocupacional se vio influenciado por cambios en contextos/entornos, acciones de actores sociales implicados y modificaciones experimentadas en su desempeño ocupacional y salud.

Palabras clave: Desalojo, Desempeño Ocupacional; Salud; Terapia Ocupacional; Crisis de vivienda; Recesión económica.

\begin{abstract}
Introduction: the global crisis has an impact on many households due to unemployment of its members encouraging housing evictions for unpaid. This affects health and occupational performance of individuals-communities. Method: it has been made a phenomenological qualitative study in A Coruña (Galicia / Spain), whose purpose intended to make an approach to the experiential construct occupational performance of these people was conducted. Results: show modifications of occupational performance and health, resulting from the experienced experiences. Conclusion: Experiential construct occupational performance was influenced by changes in contexts/environments, actions of social actors involved and experienced changes in their occupational performance and health.
\end{abstract}

Key words: Eviction, Occupational Performance; Health; Occupational therapy; Housing crisis; Economic Recession.

\title{
Extended Abstract
}

The global crisis has impact in numerous homes because of the unemployment of his members encouraging evictions of house by non-payments. This tax increased of significant way in the last years. According to the last data published by the Statistics National Institute, in the first quarter of 2015, produced a total of 11.250 executions mortgage of houses, $0,9 \%$ more than the last quarter of 2014 and 5,2\% less than in the same quarter of 2014. If we take into account the total number of familiar houses (18.363.500) existent in Spain in the first quarter of 2015, 0,048\% initiated an execution mortgage in this period. To regional level, in the first quarter of 2015 Andalucia (5.058) registered the greater number of executions mortgage of houses, in front of The Rioja and Basque Country (both with 70). Galicia, finds in an intermediate place (8/17) with a total of 445 executions mortgage of houses. All this situation repercussion in the health and in the exert occupational of individualscommunities.

We frame this work of investigation in a qualitative methodology, to treat to understand the group of characteristics interrelated with the eviction from the perspective experiential of the people. We realise a design phenomenological based in studying the human experience lived, the existential meanings dice by each person based in the perspective experiential of the protagonists, that is to say from the daily experience.

This work of investigation framed inside two paradigm (methodological and of the profession). The first, went a constructivist paradigm, since the investigation allocated to the analysis of the reality, to recognise it and explore it in his historical dimension, built, dynamic and divergent to contribute to the 
transformation and to the compression of the internal and deep relations in a process of investigation with a subjective interval so much by part of the subject researcher as of the object-subject investigated. The second corresponds with the social paradigm of the occupation, with influences of theories linked to the occupational therapy community or social, political occupational therapy and social and theory of the occupational nature.

The territory in which we have carried out the work was: city A Coruna, which stands out for having the highest figures of executions mortgage in all the autonomous community of Galicia. The study lasted 7 months, had the favourable report of the committee of ethical of investigation with the code (2016/024). The informants have selected them using an intentional theoretical sampling open, allowing find categories of people that contributed theoretical concepts of greater importance for the development of the study. To expand the possibility to interview to other people use the strategy of sampling in ball of snow. Besides we realise a triangulation of sources of data with the end to enrich the information of a social reality endowing it of methodological rigour. In summary, on the one hand study the experience of the people in situation of evictions explained by the own leading, and by another the vision of the organisms that are involved in this process. We explain besides, with participation in the process like external evaluator of a person with political charge recognised in the City council of A Coruña in the to the area of social justice and cares, with recognition and experience in this thematic and investigations in this context.

The collected of data established it by means of the interview in depth and the newspaper of field. Besides, the recordings collected in format audio by means of a digital recorder were transcribed literally, beside the data of the participants that employed for the coding and the profile sociodemographic. For the analysis of the data use an approach or approximation inductive since we happen from specifics to generals with the object to explore and describe and afterwards generate theoretical perspectives. We realise an analysis of the interviews in depth and of the annotations collected in the newspaper of field. With the object to guarantee the confidentiality of the process, each recording register it with an alphanumeric code, that only the researchers of the study knew.

The results obtained aim to modifications in the exert occupational of the participants, standing out variable of surroundings and contexts, patterns of exert and areas of the occupation. Besides, it stands out the affectation regarding the health of the people, and the importance of the social actors involved, so many social movements, public or private institutions and banking entities. The main finding obtained and ascertained with the scientific literature, shows a relation between the health of the families in situation of eviction and how these manage his everyday life in surroundings/different contexts to which until the moment presented. In relation to the findings of the investigation, can ascertain that the elements that form the exert occupational of the participants, saw engaged and generated in the people to study an effect dominated, with visible changes in them and in the form to realise the occu- 
pation in his surroundings/context, as they realised it until the moment. Regarding the findings that relate the commitment of the health in relation to the socioeconomic situation in which they find the protagonists, find evidences that corroborate said affirmations.

In accordance with the aims posed, and to the light of the results affirm that the construct experiential of exert occupational of the people that find in this situation sees influenced by several factors: changes in his contexts/surroundings, actions of all the social actors involved in this situation, modifications that these people suffer in his exert occupational and in his health like consequence of the to scale global phenomenon. Regarding the exploration of the exert occupational and the balance of the same, has corroborated the affectation that the informants perceived, because of the different repercussions in the personal contexts, temporary, physical and social surroundings, as well as in the distinct areas of the occupation, key elements in the exert occupational and his balance. Finally, stand out that the confluence of all the previously mentioned factors, of external character to the person and promoted by situations of nature political and economic, had like result a situation of occupational deprivation that nick the health of the population.

\section{INTRODUCCIÓN}

Una de las consecuencias más reseñables de la crisis económica que está afectando a nivel mundial es el desempleo y los fenómenos de desahucios, situación en la que se encuentran actualmente más de 600.000 familias españolas a causa del impago de sus alquileres o hipotecas (Mangot, 2013). Antes de continuar explicando las consecuencias que la crisis de los desahucios tiene en la sociedad española, es necesario clarificar algunos términos que circunscriben este proceso. En primer lugar, debemos diferenciar los conceptos "ejecución", "lanzamiento" o "desahucio". Si revisamos las definiciones de la Real Academia Española (2015) (in extenso RAE) el término ejecución, se entiende como "procedimiento judicial con embargo y venta de bienes para pago de deudas". El desahucio es definido como "dicho de un dueño o arrendador: despedir al inquilino o arrendatario mediante una acción legal". Por último, se encuentra el concepto de lanzamiento haciendo referencia a "despojo de una posesión o tenencia por fuerza judicial". Los términos "desahucio" y "lanzamiento" son utilizados como sinónimos, y se refieren al momento concreto en que la vivienda es despojada del propietario o inquilino, posterior a la subasta, de manera que se le obliga a abandonarla. Esta diferencia se observa fácilmente al explicar el proceso de ejecución hipotecaria (abarcando ejecuciones por impago de hipoteca o de alquiler) desde el momento del impago hasta el lanzamiento. Por último, el término "ejecución" se utiliza para referirse a todo el proceso, desde el aviso de impago hasta la fase posterior a la subasta de la vivienda, proceso que será explicado más adelante (Plataforma de Afectados por la Hipoteca, 2014). 
Todos estos procesos descritos presentan diferentes etapas por las que la persona afectada discurre. La primera fase de este proceso es la notificación de retraso del pago de las cuotas por parte de la entidad bancaria, estableciendo un plazo de 10 días para que el deudor pague la deuda, ya que en caso contrario, recibiría una nueva notificación sobre la fecha estimada de subasta de su vivienda. Hasta este momento, se pueden tomar una serie de medidas legales para intentar paralizar el proceso: negociar con la entidad bancaria, solicitar abogado de oficio, recurrir a la dación en pago, presentar alegaciones ante el tribunal Europeo de Justicia por cláusulas de contratos abusivas, o de manera previa al desahucio, acudir a la Administración Pública, solicitar ayuda de Servicios Sociales o recurrir a las asociaciones, plataformas o movimientos sociales de apoyo a las personas en situación de ejecución hipotecaria. Una vez la vivienda sea subastada, el banco es propietario del $70 \%$ del valor de la tasación, y la persona recibe una tercera notificación comunicándole el plazo del que dispone para abandonar su vivienda. Esta última fase, se puede realizar por dos vías: judicial o extrajudicial. Tras el abandono de la vivienda se produce el desahucio o lanzamiento, para el cual en algunos casos, se requiere de la intervención de las fuerzas del estado (Plataforma de Afectados por la Hipoteca, 2014).

La crisis global, resultante, entre otras, de la supuesta negligencia de bancos y cajas (Colau y Alemany, 2012) tiene impactos sociales en numerosos hogares, los ingresos económicos se ven disminuido debido a situaciones de desempleo (Mangot, 2013). Esta tasa se incrementó de manera significativa en los últimos años siendo ésta) del $8.42 \%$ en el primer trimestre de 2007 y del $23.70 \%$ en el cuarto trimestre de 2014, lo cual implica un aumento de más del doble en siete años (Instituto Nacional de Estadística, 2015) (in extenso INE). Este fenómeno cobró relevancia en los últimos años, incrementándose considerablemente. El 2011 pasó a ser un año negro y será recordado como el año de la indignación, de las protestas del desarrollo de movimientos sociales. Desde el 2011 hasta el 2014 se dieron una serie de situaciones donde la crisis económica fue en aumento, el poder del sector financiero comenzó a tambalearse, empezó de forma notable la desigualdad de ingresos económicos y se inició el drama de las hipotecas (Castell, 2013). Según los últimos datos publicados por el INE (2015), en el último trimestre del año 2014 se llevaron a cabo, a nivel nacional, un total de 8.780 ejecuciones hipotecarias. En el primer trimestre de 2015 , se produjeron un total de 11.250 ejecuciones hipotecarias de viviendas, un $0,9 \%$ más que el último trimestre de 2014 y un 5,2\% menos que en el mismo trimestre de 2014. Si tenemos en cuenta el número total de viviendas familiares (18.363.500) existentes en España en el primer trimestre de 2015, el 0,048\% iniciaron una ejecución hipotecaria en ese periodo. A nivel regional, en el pri- 
mer trimestre de 2015 Andalucía (5.058) registraba el mayor número de ejecuciones hipotecarias de viviendas, frente a La Rioja y País Vasco (ambas con 70). Galicia, se encuentra en un puesto intermedio (8/17) con un total de 445 ejecuciones hipotecarias de viviendas. Según el Instituto Gallego de Estadística (2015) (in extenso IGE), en el año 2014 se llevaron a cabo 2016 ejecuciones hipotecarias, y un total de 325 por impago de alquileres, siendo A Coruña (838) una de las provincias con más casos.

Dejando a un lado las repercusiones económicas y abarcando las consecuencias que la crisis tiene en todos los niveles, encontramos que el aumento de estos procesos de ejecución de las viviendas por impago, de alquiler o hipotecario, tiene consecuencias en otras esferas de la sociedad española. Los movimientos del tercer sector dirigido por los ciudadanos que luchaban por el derecho a una vivienda justa ante un ciclo económico adversos (Sequera, 2011), dieron paso tras la explosión de la burbuja inmobiliaria al desarrollo de movimientos sindicales y sociales, cuyo objetivo es la defensa de las personas afectadas por esta situación, como son "Democracia Real YA!", "Juventud Sin Futuro" "Movimiento 15-M" o, el de mayor éxito por su repercusión social, "Plataforma de Afectados por la Hipoteca" (in extenso PAH). La PAH surge del movimiento "V de vivienda" y destaca frente a los demás por diversos factores: estructurales, de coordinación, repercusión social o efectividad en las acciones. Desde su nacimiento en Barcelona en 2009, paralizó 2045 desahucios y, en su obra social, se realojaron a 2500 familias (Cano y Extezarreta, 2014). Una de las claves del éxito de la PAH es la manera en la que surge y la velocidad en la que se disemina por el resto del país. Este movimiento se creó a partir de la unión de personas afectadas y sobrepasadas con esta situación, que abogaban por el cambio social (Mangot, 2013). La actividad de los núcleos que componen la PAH, ofreciendo sinergias entre sí y su carácter asambleario fue la clave del éxito funcional de esta plataforma (Adell et al., 2014). La PAH se define como un movimiento social, conformado por afectados y voluntarios, que llevan a cabo acciones de asesoramiento, movimientos de protesta, concentraciones y difusión del fenómeno. Según Cano y Etxezarreta (2014), el movimiento anti-desahucios en España es convulso en cuanto a la denuncia y defensa de las vulnerabilidades relacionadas con la vivienda, encajando en un marco de innovación social, (convergencia de iniciativas sociales y comunitarias destinadas a satisfacer necesidades sociales).

La PAH cubrió numerosos escenarios cuya responsabilidad correspondía a las administraciones públicas (Adell $e t$ al., 2014). Esta plataforma fue clave para lidiar con numerables situaciones tales como las grandes desigualdades a nivel social, tendiendo a una desaparición del estado de bienestar y a una mayor ruptura de clases sociales. Algunos autores y autoras comparan este fenó- 
meno con la crisis Argentina de 2001 (De la Rosa, 2014), pero también existen fenómenos comunes en otros países: la crisis inmobiliaria en Estados Unidos, Inglaterra o Grecia incrementó el número de suicidios entre los años 20052010, pasando a ser la segunda causa de muerte (Fowler et al., 2015). En España, se observan cierta influencia de factores socioeconómicos relacionados con pérdida del empleo o vivienda y la afectación de la salud mental en personas allegados que se encuentran en esta situación, aumentando así los episodios de depresión, dependencia al alcohol o fármacos, malestar general, bajo estado de ánimo, o aumento de la tentativas autolíticas (Menéndez et al., 2013). Autores como Gil y Campuzano (2014) desarrollan la idea de que a consecuencia de las crisis hay más sectores de la población expuestos a la pobreza, desempleo, exclusión y precariedad laboral, lo cual puede aumentar la desigualdad social de la salud.

Para destacar la importancia que todos estos factores que hemos detallado tienen en la salud de las personas y comunidades, debemos tener en cuenta la actual definición de salud y determinantes sociales de la salud (in extenso DSS). La salud es definida por la Organización Mundial de la Salud (in extenso OMS) (López y Frías-Osuna, 2000) en el año 1946 como estado de completo bienestar físico y mental, y no solo la ausencia de enfermedad. Esta definición fue criticada por diversos autores y autoras a mediados del siglo XX por considerarla estática, subjetiva y utópica, por lo que se propusieron diversas alternativas. Actualmente, se evolucionó hacia un concepto dinámico y ecológico de salud, en el cual se incluye la interacción entre cuatro factores: biología humana (genética, envejecimiento), estilo de vida (conductas de salud), medio ambiente (contaminación química, física, biológica, psicosocial y cultural) y el Sistema de Asistencia Sanitaria. En el año 2003, la OMS (Mejía, 2013) propuso crear una política de relación de conocimiento y acción para enfocar sus intervenciones a reducir las inequidades en salud, y en 2005 se conformó la Comisión de Determinantes Sociales de la Salud (in extenso CDSS), los cuales son definidos como aquellos factores biológicos, ambientales, políticos, económicos y culturales que determinan y condicionan la salud de población en general, y que dependiendo de su naturaleza (positiva o negativa) pueden ser factores de protección o de riesgo. A partir de ese momento, se realizaron múltiples investigaciones acerca de cómo influyen los factores socioeconómicos en la salud de las personas.

Para comprender la transcendencia que esta situación tiene desde la perspectiva de la terapia ocupacional, debemos comenzar mencionando que esta es una disciplina que promueve la salud y el bienestar de las personas a través de la ocupación, siendo su meta primordial que todas ellas participen en las ocupaciones que personalmente quieren hacer, necesitan hacer o que en su cultu- 
ra y sociedad se espera que hagan (Moruno y Romero, 2003). Su práctica se basa en la idea de que el ser humano es un ser ocupacional por naturaleza ya que las actividades que realiza la persona, aportan significado a su vida, organiza el espacio y el tiempo en los que se lleva a cabo y permite a la persona relacionarse con sus entornos y contextos. Además la ocupación, potencia el bienestar psicológico y social de la persona (aspectos esenciales en el concepto actual de salud) está relacionado con la capacidad de la ésta para realizar ocupaciones socialmente valoradas Wilcock (2006). Esto tiene sentido en lo relativo a la perspectiva de Moruno y Romero (2003), desde la cual la ocupación es una pieza esencial en la consecución del bienestar y, como consecuencia, en su estado de salud, al ser el vehículo que la relaciona con su entorno y contexto y que permite que se desarrolle en éstos de manera significativa.

De esta interacción entre persona-entorno-ocupación surge el concepto de desempeño ocupacional, el cual es responsable de las variaciones del estado de bienestar y calidad de vida. Para garantizar un beneficio en estos aspectos, es necesario que el desempeño ocupacional esté equilibrado (Gómez, 2006), entendiendo éste, como resultado de la adaptación a nivel interno del individuo en base a las demandas del entorno por medio de las actividades en las que nos comprometemos.

Además, se observa que la persona-ocupación-entorno forma una tríada que garantiza la salud y el bienestar de las personas y comunidades, y por ende equilibrio en el desempeño ocupacional. Este, puede verse afectado por la variación de cualquiera de sus componentes. Un desequilibrio causado por factores externos de carácter político o económico, conduciría a la deprivación ocupacional (Towsend y Wilcock, 2004) siendo responsable de dificultar o impedir el acceso a recursos y oportunidades de participación en actividades que resultan culturalmente significativas en el entorno de las personas o comunidades, repercutiendo en el desarrollo social, cultural y económico.

Por tanto, teniendo en cuenta que aquellas personas que se encuentran afectadas por la crisis de los desalojos en Galicia presentan una pérdida de su hogar, el cual es una parte esencial en su entorno y desarrollo de la ocupación, se considera importante realizar un análisis del desempeño ocupacional de estas. Para ello nuestro objetivo general será el de realizar una aproximación al constructo vivencial del desempeño ocupacional de las personas en situación de desalojo. Mientras que los objetivos específicos: (a) explorar las características básicas del desempeño ocupacional, (b) analizar los elementos del equilibrio ocupacional, (c) indagar la gestión de los informantes sobre los entornos y contextos desde donde se desarrolla la ocupación. 


\section{METODOLOGÍA}

\section{Diseño del estudio}

Enmarcamos este trabajo de investigación en una metodología cualitativa, para tratar de entender el conjunto de características interrelacionadas con el desalojo desde la perspectiva vivencial de las personas (Ruiz, 2012). Realizamos un diseño fenomenológico (Salgado, 2007) fundamentado en estudiar la experiencia humana vivida, los significados existenciales dados por cada persona basados en la perspectiva vivencial de los protagonistas, es decir desde la experiencia cotidiana (lo básico de la vida, el aspecto más primario que aporta identidad y significado) (Talavera, 2012).

Este trabajo de investigación se enmarcó dentro del paradigma metodológico constructivista interpretativo (Guba y Lincoln, 2002), ya que la investigación se destinó al análisis de la realidad, a reconocerla y explorarla en su dimensión histórica, construida, dinámica y divergente para contribuir a la transformación y a la compresión de las relaciones internas y profundas en un proceso de investigación con un intervalo subjetivo tanto por parte del sujeto investigador como del objeto-sujeto investigado. Sin embargo, el paradigma de la terapia ocupacional corresponde con el paradigma social de la ocupación (Morrison et al., 2011), con influencias de teorías vinculadas a la terapia ocupacional comunitaria o social, terapia ocupacional política y social y teoría de la naturaleza ocupacional e inferencias del Occupational therapy practice framework: Domain and process (American Occupational Therapy Association, 2014) como modelo profesional de terapia ocupacional en la categorización de datos.

\section{Participantes}

El territorio en el que hemos llevado a cabo el trabajo fue: ciudad A Coruña, la cual destaca por tener las cifras más altas de ejecuciones hipotecarias en toda la comunidad autónoma de Galicia. Hemos seleccionado a las personas informantes utilizando un muestreo teórico intencionado abierto (Hernández et al., 2010b), permitiendo encontrar categorías de personas que aportasen conceptos teóricos de mayor relevancia y que cumplieran unos criterios de selección para el desarrollo del estudio. En la tabla 1, se especifican los criterios de selección empleados en cada categoría de informantes.

Para ampliar la posibilidad de entrevistar a otras personas utilizamos la estrategia de muestreo en bola de nieve (Hernández et al., 2010b), consistente en que una vez se estableció el contacto con algunos informantes, éstos y éstas facilitaron el contacto y ubicación de otros y otras. Además realizamos una triangulación de fuentes de datos (Okuda y Gómez-Restrepo, 2005) con el fin 
Tabla1. Criterios de inclusión y exclusión empleados para seleccionar la muestra

\begin{tabular}{|c|c|c|}
\hline & Inclusión & Exclusión \\
\hline $\begin{array}{l}\text { Criterios selección } \\
\text { personas en } \\
\text { situación de } \\
\text { desalojo. }\end{array}$ & $\begin{array}{l}\text { Edad igual o superior a los } 18 \text { años. } \\
\text { Ser el titular de la hipoteca por la que se } \\
\text { realiza el desalojo. } \\
\text { Encontrarse en situación de desalojo por } \\
\text { impago de la hipoteca de su residencia. } \\
\text { Encontrarse con el proceso de desalojo } \\
\text { finalizado o a partir de la fase pre- } \\
\text { subasta. }\end{array}$ & $\begin{array}{l}\text { Presentar un problema de } \\
\text { salud que perjudique la } \\
\text { recogida de datos. } \\
\text { Residir fuera del área } \\
\text { metropolitana de A Coruña. } \\
\text { Ser propietario de dos } \\
\text { viviendas. }\end{array}$ \\
\hline $\begin{array}{l}\text { Criterios selección } \\
\text { organismos } \\
\text { defensores de } \\
\text { derechos. }\end{array}$ & $\begin{array}{l}\text { Unidades u organizaciones cuyo objeto } \\
\text { sea el establecimiento o la defensa de } \\
\text { los intereses de las personas en } \\
\text { situación desalojo. } \\
\text { Sede física en la ciudad de A Coruña. } \\
\text { Carácter público o informal. }\end{array}$ & $\begin{array}{l}\text { Entidades con ánimo de } \\
\text { lucro. } \\
\text { Llevar a cabo acciones de } \\
\text { carácter asistencial. }\end{array}$ \\
\hline $\begin{array}{l}\text { Criterios selección } \\
\text { entidades } \\
\text { intervención } \\
\text { comunitaria. }\end{array}$ & $\begin{array}{l}\text { Organismos con carácter público, } \\
\text { privado y colectivos sociales. } \\
\text { Sede en la ciudad de A Coruña. } \\
\text { Trabajar junto a personas mayores de } \\
\text { edad en situación de desalojo } \\
\text { hipotecario. } \\
\text { Entidades de intervención social. }\end{array}$ & $\begin{array}{l}\text { Actuaciones dirigidas a la } \\
\text { asesoría jurídica. } \\
\text { Actuaciones en el ámbito } \\
\text { socioeducativo. }\end{array}$ \\
\hline
\end{tabular}

Fuente: elaboración propia. 2016

de enriquecer la información de una realidad social dotándola de rigor metodológico. En resumen, por un lado estudiamos la vivencia de las personas en situación de desalojo contada por los propios protagonistas, y por otro la visión de los organismos que están involucrado en este proceso.

El número final de informantes fue $n=11$ participantes (tabla2), a los cuales accedimos por medio de la figura del gatekeeper ${ }^{1}$. Detuvimos la recolección de datos mediante las entrevistas cuando los datos adicionales no aportaban

${ }^{1}$ Persona que tuvo un papel regulador en el acceso al campo, es decir autorizándonos y facilitándonos la entrada en el ambiente. Ayudó en la localización de personas participantes, pero no influyó en la selección de estas para el estudio. 
Tabla2. Descripción de informantes

\begin{tabular}{|c|c|c|c|c|c|c|c|}
\hline Código & $\mathbf{G}$ & $\mathbf{E}$ & ROrg & REst & $\mathbf{N}$ & Entidad & ROL \\
\hline A1M36U & M & 36 & $\begin{array}{l}\text { SEMIURB } \\
\text { (Uruguay) }\end{array}$ & $\begin{array}{l}\text { URB } \\
\text { (A Coruña) }\end{array}$ & Ur & $\begin{array}{l}\text { Stop Desahucios } \\
\text { (A Coruña) }\end{array}$ & Afectado \\
\hline C1F31TS & F & 31 & $\begin{array}{l}\text { URB } \\
\text { (A Coruña) }\end{array}$ & $\begin{array}{l}\text { URB } \\
\text { (A Coruña) }\end{array}$ & Esp & Caritas & Trabajadora Social \\
\hline A3F39U & F & 39 & $\begin{array}{l}\text { URB } \\
\text { (A Coruña) }\end{array}$ & $\begin{array}{l}\text { URB } \\
\text { (A Coruña) }\end{array}$ & Esp & $\begin{array}{l}\text { Stop Desahucios } \\
\text { (A Coruña) }\end{array}$ & Afectada \\
\hline A6F34U & F & 34 & $\begin{array}{l}\text { URB } \\
\text { (A Coruña) }\end{array}$ & $\begin{array}{l}\text { URB } \\
\text { (A Coruña) }\end{array}$ & Esp & $\begin{array}{l}\text { Stop Desahucios } \\
\text { (A Coruña) }\end{array}$ & Afectada \\
\hline A7F37U & $\mathrm{F}$ & 37 & $\begin{array}{l}\text { URB } \\
\text { (A Coruña) }\end{array}$ & $\begin{array}{l}\text { URB } \\
\text { (A Coruña) }\end{array}$ & Esp & $\begin{array}{l}\text { Stop Desahucios } \\
\text { (A Coruña) }\end{array}$ & Afectada \\
\hline V2M34 & M & 34 & $\begin{array}{l}\text { URB } \\
\text { (A Coruña) }\end{array}$ & $\begin{array}{l}\text { URB } \\
\text { (A Coruña) }\end{array}$ & Esp & $\begin{array}{l}\text { Stop Desahucios } \\
\text { (A Coruña) }\end{array}$ & $\begin{array}{l}\text { Voluntario, } \\
\text { no afectado, } \\
\text { portavoz }\end{array}$ \\
\hline A5M42U & M & 42 & $\begin{array}{l}\text { URB } \\
\text { (A Coruña) }\end{array}$ & $\begin{array}{l}\text { URB } \\
\text { (A Coruña) }\end{array}$ & Esp & $\begin{array}{l}\text { Stop Desahucios } \\
\text { (A Coruña) }\end{array}$ & Afectado \\
\hline A2F33U & F & 33 & $\begin{array}{l}\text { URB } \\
\text { (Ourense) }\end{array}$ & $\begin{array}{l}\text { URB } \\
\text { (A Coruña) }\end{array}$ & Esp & $\begin{array}{l}\text { Stop Desahucios } \\
\text { (A Coruña) }\end{array}$ & $\begin{array}{l}\text { Afectada, } \\
\text { voluntaria }\end{array}$ \\
\hline A4M56U & M & 56 & $\begin{array}{l}\text { URB } \\
\text { (A Coruña) }\end{array}$ & $\begin{array}{l}\text { URB } \\
\text { (A Coruña) }\end{array}$ & Esp & $\begin{array}{l}\text { Stop Desahucios } \\
\text { (A Coruña) }\end{array}$ & $\begin{array}{l}\text { Afectado, } \\
\text { voluntario }\end{array}$ \\
\hline V1F32 & F & 32 & $\begin{array}{l}\text { URB } \\
\text { (Vigo) }\end{array}$ & $\begin{array}{l}\text { URB } \\
\text { (A Coruña) }\end{array}$ & Esp & $\begin{array}{l}\text { Stop Desahucios } \\
\text { (A Coruña) }\end{array}$ & $\begin{array}{l}\text { Voluntaria, } \\
\text { no afectada, } \\
\text { comunicación. }\end{array}$ \\
\hline C2F29TS & $\mathrm{F}$ & 29 & $\begin{array}{l}\text { URB } \\
\text { (A Coruña) }\end{array}$ & $\begin{array}{l}\text { URB } \\
\text { (A Coruña) }\end{array}$ & Esp & Caritas & Trabajadora Social \\
\hline
\end{tabular}

G: género; E: edad; ROrg: residencia de origen; REst: residencia durante el estudio; N: nacionalidad; ROL: rol en la entidad; URB: urbana; SEMIURB: semiurbana; F: femenino; M: masculino; Esp: Española; Ur: Uruguaya. Fuente: elaboración propia. 2016.

al desarrollo de la teoría, es decir cuando se llegó a la saturación teórica (Arias y Giraldo, 2011). Las características socio-demográficas de la población de estudio la conformaron 7 participantes mujeres y 4 hombres con edades comprendidas entre los 27 y 56 años. Contamos además, con participación en el proceso como evaluadora externa (Hernández et al., 2010a) de una persona con cargo político reconocido en el Ayuntamiento de A Coruña en el al área de justicia social y cuidados, con reconocimiento y experiencia en esta temática e investigaciones en este contexto. 


\section{PROCEDIMIENTOS}

El estudio duró 7 meses, contó con el informe favorable del comité de ética de investigación con el código (2016/024). Se inició en noviembre de 2015 y finalizando en junio de 2016. Se dividió en tres fases. La primera, abarcó desde el comienzo del proceso hasta enero de 2016, y consistió en la realización de la búsqueda bibliográfica, la elaboración del proyecto y petición de permisos. A continuación, realizamos la selección de informantes y entrada a campo, finalizando esta fase en abril 2016. Por último, el mes de mayo estuvo destinado a la elaboración del informe final.

En cuanto a la posición y experiencia de las y los investigadores, buscamos una postura reflexiva intentando minimizar la influencia que sobre los y las participantes pudiéramos ejercer sobre sus creencias o fundamentos asociados al objeto de estudio. La aproximación al contexto la realizamos desde un conocimiento teórico-práctico. La recogida de datos la establecimos mediante la entrevista en profundidad y el diario de campo (Vargas, 2012).

Con el afán de no perder información que fuera relevante para su posterior análisis, realizamos las anotaciones de este diario en momentos previos al comienzo de las interacciones con las personas participantes y siempre al terminar cada entrevista. Las anotaciones las estructuramos en tres categorías, metodológicas, teóricas y descriptivas. Así mismo, las archivamos de forma independiente por evento, tema y periodo (Hernández et al., 2010c).

En cuanto a las grabaciones recogidas en formato audio mediante una grabadora digital, fueron transcritas literalmente junto a los datos de los participantes que se emplearon para la codificación y el perfil sociodemográfico.

\section{Análisis de los datos}

Utilizamos un enfoque o aproximación inductiva (Hernández et al., 2010c) ya que pasamos de lo particular a lo general con el objeto de explorar y describir y luego generar perspectivas teóricas. Realizamos un análisis de las entrevistas en profundidad y de las anotaciones recogidas en el diario de campo. Con el objeto de garantizar la confidencialidad del proceso, cada grabación la registramos con un código alfanumérico, que solo los investigadores del estudio conocíamos. Después de la transcripción literal de las entrevistas, cada persona investigadora llevó a cabo un análisis independiente de los datos con la ayuda del software Atlas Ti. 6.0. Las tres personas investigadores organizaron codificadores de datos comparando las notas e interpretaciones de los análisis individuales, al tiempo que discutían cómo llegar al consenso. Posteriormente, recopilamos las unidades en categorías y más tarde comparamos las categorías entre sí para agruparlas en temas. En cuanto al proceso de análisis, lo realiza- 
mos incorporando concepciones de diversos teóricos de la metodología en el campo cualitativo, en base a los resultados que se encontraron conforme avanzaba del proceso, sin haber establecido un esquema previo de los mismos (Hernández et al., 2010c). Una vez finalizado el trabajo, las grabaciones y transcripciones fueron destruidas.

\section{Resultados}

Los resultados obtenidos (figura 1), apuntan hacia modificaciones en el desempeño ocupacional de las personas participantes, destacando variables de entornos y contextos, patrones de desempeño y áreas de la ocupación. Además, des-

Figura 1. Correspondencias obtenidas en el análisis de los datos recopilados en la investigación entre Temas, Categorías, Sub-categorías y códigos

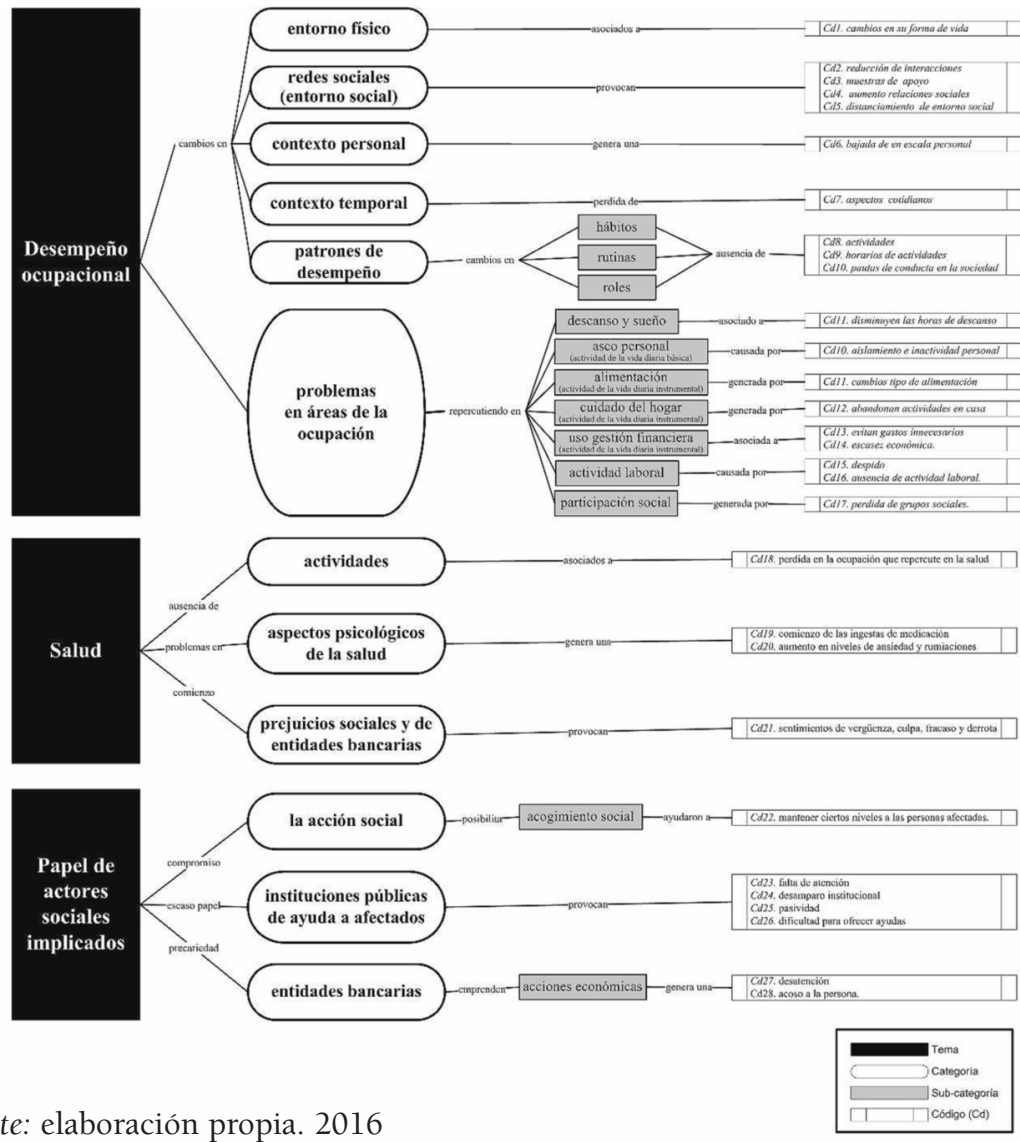

Fuente: elaboración propia. 2016 
taca la afectación en cuanto a la salud de las personas, y la relevancia de los actores sociales implicados, tantos movimientos sociales, instituciones públicas o privadas y entidades bancarias.

En primer lugar encontramos el tema denominado "desempeño ocupacional", en el cual emergieron diferentes categorías que agrupan las habilidades de percibir, desear, recordar, planificar y llevar a cabo roles, rutinas, tareas y pasos, con el propósito de que la persona pueda desarrollar las diferentes áreas de la ocupación, en respuesta a las demandas de entorno. Así, en la primera categoría, el entorno físico, hubo personas a las que el cambio les fue indiferente, mientras que a otros participantes, cambiar de entorno o el mero hecho de planteárselo como una opción real, aunque no llegase a realizarlo, si les supuso ciertos cambios:

(...) Cambios en mi forma de vida: a mí tanto me da dónde vivir, (...) (A.6F34U).

(...) pasé de mi casa a un piso con 36 años, con dos hijos, en una habitación, como un estudiante, no es lo mismo, claro. (A.1M36U).

De igual forma, en la siguiente categoría, las redes sociales (entorno social) los cambios propiciaron modificaciones en las formas de mantenerlas. Algunos participantes hablaron de la reducción de esta interacción con otros:

...tuve una desestructuración de familia, esto llevó a problemas familiares, de pareja y (...) lo llevaba lo mejor posible." (A.1M36U).

Así mismo, algunos participantes destacaron, que con esta situación su red social, les mostró más apoyo e incluso, otros participantes manifestaron que esta situación generó una ampliación de las relaciones sociales que hasta ese momento mantenían:

... gracias a Dios como está ahí mi madre, pues siempre me ayudaba, pero (...) eres una persona adulta no quieres ser una carga" (A.7F37U).

... socialmente (...) me benefició, aunque parezca mentira..., tenía más tiempo para dedicarles a mis amigos... (A.1M36U).

Por otro lado, a pesar de que en algunos casos la familia adoptó una actitud de apoyo, las experiencias y cambios en los patrones de desempeño que conlleva el proceso de desalojo implicó un distanciamiento involuntario de su entorno social:

...el poco tiempo que tengo lo tengo que repartir entre la niña (...) recabar información, para poder defenderme... no tuviera este problema se lo dedicaría sólo a ella. (A.3F339U).

En el caso de algunas personas participantes, en la siguiente categoría: contexto personal, hubo una ruptura con situaciones percibidas que generaron reac- 
ciones en cadena a la hora de la competencia ocupacional, así para algunos la sensación de bajada en la escala tras el desalojo fue una de las respuestas que más aparecían en su narrativas:

...dejas de existir, (...) de no ser ciudadano, de que tú ves tus derechos, que creías que tenías, pasas a ser...eso, un fantasma, una sombra. (A.4M56U).

A su vez, el contexto temporal (otra de las categorías), representó una incertidumbre y una inestabilidad que generó en sus narrativas, una pérdida de aspectos relacionados con lo cotidiano, incluso este cambio repercutió en lo institucional:

... te queda parte de aquella deuda... que te perseguirá toda la vida: los intereses suben (...) es una ruina" (A.7F37U).

...quedas condenada a no poder comprar nada durante muchísimos años porque arrastras deudas. Sólo que vayas a telefónica, a hacer un contrato de un móvil ya no puedes. No puedo tener una tarjeta de crédito, no puedes tener la tarjeta de "El Corte Inglés"..., no, no puedo comprar una lavadora a plazos no, porque siempre está aquello allí. (A.6F34U).

Estas modificaciones en las anteriores categorías, generaron una serie de cambios en los patrones de desempeño, que motivó que en esta categoría se evidenciara un antes y un después en la gestión de los hábitos, las rutinas y lo roles:

... tu vida pasa de girar en torno a tu familia y a tu hija, a girar en torno a ese problema. El resto secundario: familia, trabajo (...) (A.3F39U).

Todas estas variaciones en los diferentes entornos, contextos y patrones de desempeño, generan una fluctuación clara en la siguiente categoría, las áreas de la ocupación, destacando áreas tales como el descanso y el sueño, en donde se observaron respuestas vinculadas con la modificación de actividades relacionadas con el sueño, con pérdida en ocasiones de ritmos de vigilia:

... empecé a dormir mal, no podía más (A 1M36U).

... no desconectas, no descansas, es una lucha constante (A.3F39U).

Además, se produjo un deterioro en el aseo personal (actividades de la vida diaria básicas) y actividades de ocio, con una tendencia progresiva de las personas al aislamiento y la inactividad en cuanto a esta área.

A todo esto se le sumaron los cambios en las actividades de la vida de diaria instrumental (alimentación) por la escasez de recursos económicos, y en las actividades de la vida diaria instrumental (cuidado del hogar), lo que generó reacciones en las personas de evitación de gastos innecesarios, repercutiendo además en el uso de la gestión financiera (actividad de la vida diaria instrumental): 
...con el paso de tiempo se iba descuidando su aspecto físico (C.1F31TS).

... los viernes quedaba con mis amigas para tomar un café después de trabajar, ahora no lo puedes hacer (...) Y te sientes mal, porque tú dices: llegará el momento que dejen de llamarte (A.2F33U).

... tener que darle el biberón frío porque no había (llora)... (V.2M34).

... no puedes... ni comprarte algo para la casa, en un piso en que te puedes ir en cualquier momento, no sabes si te vas a quedar o te vas a ir, vives en una casa desorganizada (...) no inviertes un duro en la casa (A.3F39U).

... te conviertes en lo que se dice una "economía de guerra": todo lo que es superfluo, (...) es suprimido... La tarjeta de crédito que antes te daban con alegría ya no existe (...) (A.4M56U).

Estas situaciones condicionadas a la escasez económica, derivaron una falta de actividad laboral que, de forma tácita, marcó un punto de inflexión en los discursos de los participantes y que son clave para entender alguna de las variables influyentes en los desalojos:

(la gente) desahuciada por un tema de deuda hipotecaria es gente con una vida laboral amplia (...) con una vida normalizada, que tenía su trabajo (...) de repente, se acabó el trabajo y yo esto ahora cómo lo pago (C.2F29TS).

Viéndose incluso limitada la actividad en la participación social de los y las participantes:

(...) no tenía yo el humor para andar con (...) socializar, vamos (A.4M56U).

El segundo tema, denominado "salud", narra el vínculo de la falta de actividad con la salud, el cual es fluctuante en los actores implicados. La repercusión de la ausencia de actividad, afectaron de forma evidente, formando parte esencial de las constantes narraciones de los participantes:

... además eso, tiene repercusiones en tu salud, en tu estado de ánimo, en todo, en todos los aspectos de tu vida, claro (A.4M56U).

Las respuestas que se dieron en las personas afectadas, se vincularon con falta de salud, desembocando en el fallecimiento de algunos afectados, así como en problemas con respecto a los aspectos psicológicos de salud, entre los que destacan las constantes rumiaciones sobre la situación, sentimientos de miedo/ angustia/nerviosismo a causa de estos pensamientos y estos elevados niveles de nerviosismo generaron incertidumbre en las personas afectadas:

(...) se murió por la situación, claro, por el estrés, y... el cansancio y demás (A.3F39U).

... lo que te mata es esa carga, la incertidumbre de no saber qué vas a hacer, qué vas a tener (A.7F37U). 
... a nivel psicológico sí, horrible, pasé unos nervios que en mi vida Yo era una persona tranquila y ahora...tiene gran nerviosismo a raíz de aquello (A.2F33U).

Además, los prejuicios que la sociedad emitió acerca de las personas que se encuentran en esta situación, así como el trato que éstos recibieron por parte de las entidades bancarias e instituciones públicas, generó en éstas personas sentimientos de vergüenza y culpa. El cúmulo de esta situación, provocó que en las narrativas de los participantes aparezca el fracaso y la derrota:

... les hacen creer que si no pueden pagar su hipoteca es culpa suya, por haberse metido fue una época donde nos la metieron doblada (V.1F32), .. es un bajón, $y$ es un fracaso a nivel personal, ¿no? lo vives como un fracaso: ¿Por qué yo no pude conseguir esto con lo que me había esforzado? (A.2F33U).

Por último, encontramos el tema del "papel de los actores sociales implicados". En el transcurso de un desalojo, el vínculo del participante con las diferentes estructuras implicadas se mostró de forma clara en sus discursos, con constantes verbalizaciones sobre su función o la dificultad por adquirir un compromiso con la situación previa o tras desalojo. El papel de organizaciones tanto públicas como privadas, generó en los protagonistas diferentes reacciones en sus discursos:

... gracias a todos los movimientos anti desahucios que hubo las cosas han ido mejorando (C.2F29TS).

La acción social, destaca en cuanto a la creación de movimientos sociales, que fueron en un primer momento el punto de anclaje de los participantes. Estos movimientos ayudaron a mantener ciertos niveles en las personas afectadas, cumpliendo, según los participantes, cuatro estratos de ayuda.

El primero hace referencia al nivel de acogimiento social, el siguiente de mediación frente al desalojo, otro de denuncia social y, para finalizar de orientación:

... a partir de Stop desahucios hablé con ellos y me sentí bastante arropado (A.5M42U).

... procuramos apoyarlos a algunos en ese mes para que no les inicien trámites judiciales y no los desahucien del piso (C.2F29TS).

... que otro tipo de políticas de vivienda es, son posibles, (...) Y que... la situación en España es terrible (V.1F32).

Como segunda categoría, de este tema, los participantes destacaron el papel de las instituciones públicas de ayuda a los afectados en los desalojos, destacaron la falta de atención, o reacción de estos niveles de atención, generando situaciones de desamparo institucional y en ocasiones de pasividad ante la situación:

... las instituciones tienen conciencia cero, se toma el que me ayudes como una beneficencia (A.7F37U). 
Toda esta situación generó en las familias una dificultad para percibir ayudas, lo que incluso les llevó a recurrir al sector privado (asociaciones de afectados o similares) para resolver la situación:

... gente que termina de cobrar la prestación y no encuentra trabajo, viven con $400 €$ paga recibos, come... Es muy complicado (A.3F39U).

La tercera categoría emergente, corresponde a las entidades bancarias, agentes que durante la crisis fueron la válvula reguladora de la situación y que generaron en las personas afectadas malestar, y dificultad para gestionar aspectos de índole económica. Las acciones económicas que las entidades bancarias acometían sobre esta población a estudio generaban situaciones hilarantes para los afectados, con niveles de desatención y acoso a la persona:

... contrata unas líneas telefónicas de reclamaciones (...) te llaman, a le decían que le iban a quitar a sus hijos si se quedaba sin vivienda a mí me llamaban al trabajo a cada rato también (...) te hacian sentir como un ciudadano de tercera hace mucho daño (A.1M36U).

... a raiz de la crisis, la mayoría de los casos que atendemos por hipoteca son familias normalizadas (C.1F31TS).

Las acciones de estos bancos, hizo que el perfil de unidades familiares que se encuentran en situación de desalojo cambiase, de manera que los núcleos "familiares normalizados" pasaron a encontrarse en una situación de riesgo de exclusión social. De este modo, el perfil predominante es el de mujer de mediana edad divorciada o en proceso de divorcio, aunque también se dieron casos "cronificados", de personas que se encontraban previamente en riesgo de exclusión social y, en cuyos casos, el desalojo supone una problemática añadida:

... la mayoría de los casos que atendemos por hipoteca son familias normalizadas (C.1F31TS).

... si sacásemos estadísticas probablemente tendría cara de mujer... y de mujer mayor, o sea, los casos más sangrantes (V.1F32).

... nosotros atendemos más de desahucios por alquileres porque son casos que ya estamos atendiendo por otras cosas y que este año tienen el problema del desahucio, pero para el año lo vamos a seguir atendiendo por otra cosa que no sea el desahucio (C.1F31TS).

\section{Discusión}

El principal hallazgo obtenido y constatado con la literatura científica, muestra una relación entre la salud de las familias en situación de desahucio y cómo estas gestionan su cotidianeidad en entornos/contextos diferentes a los que hasta el momento presentaban. En la discusión analizamos los principales 
resultados de la investigación a partir de la secuencia empleada en la exposición de los resultados. Por ese motivo, en primer lugar, describiremos los principales hallazgos sobre el desempeño ocupacional y personas con desahucio. Tras esa parte enfatizaremos en los datos sobre el compromiso con la salud de esta población, para acabar matizando cómo los agentes implicados fueron piedra angular en este tipo de población en situación o riesgo de desahucio.

En relación al primer hallazgo de la investigación, podemos constatar que los elementos que forman el desempeño ocupacional de los participantes, se vieron comprometidos y generaron en las personas a estudio un efecto dominó, con cambios visibles en ellos y en la forma de realizar la ocupación en su entorno/ contexto, tal y como la realizaban hasta el momento. Encontramos evidencia científica que confirma el hecho de que la crisis económica y la creciente desigualdad social influyen en el desempeño ocupacional y salud de las personas. España es el tercer país con la tasa de riesgo de pobreza más elevada de Europa $(21.8 \%)$ y el que mayor brecha social tiene en el mismo contexto, contando con más de 3.000.000 de personas que actualmente viven en condiciones de "extrema pobreza (Van Bruggen, 2014). Este proceso de empobrecimiento, el cual discierne del clásico concepto de "pobreza" debido a su componente multifactorial y su carácter creciente (De la Vega, 2014), produce cambios en la vida cotidiana de aquellas personas que antes del comienzo de la crisis financiera internacional no se encontraban en el umbral de la pobreza, (Sánchez-Valdemoro, 2015), lo cual se encuentra relacionado con los resultados hallados en este estudio acerca de los contextos personal y temporal, respecto a situaciones como el descenso en la escala social y pérdida de lo cotidiano.

En esta línea, corroboramos que las principales repercusiones recaen sobre los patrones de desempeño, las actividades de la vida cotidiana que se encuentran en relación con las áreas de descanso (dormir), actividades instrumentales de la vida diaria (alimentación, mantenimiento del hogar) ocio y participación social, incluyéndose además el área de educación (en caso de los hijos de estas familias) (Sánchez-Valdemoro, 2015). En este último caso, el pacto de silencio en las familias para no desestabilizar a los hijos e hijas generó un efecto boomerang ya que ante esta actitud los adolescentes comenzaron a repetir estas conductas de evitación en esferas como la educación o las relaciones interpersonales, situación similar a lo recogido por la AAVV (2016).

Por último, destacamos la influencia que esta situación de empobrecimiento y crisis tiene sobre los entornos físico y social de la población española. En primer lugar, el entorno físico (vivienda), se considera el nivel en que las personas llevan a cabo sus actividades cotidianas (Núñez, 2012), y su pérdida, tiene repercusiones en todos los aspectos del desempeño ocupacional mencionados 
anteriormente (Sánchez-Valdemoro, 2015). Además, también se perciben influencias de ésta problemática en el entorno social. Un estudio longitudinal acerca de las relaciones familiares, la economía y la salud de los miembros de las familias afectadas por el desempleo, evidencia que la crisis española y el desempleo se deben considerar como un factor de riesgo en cuanto a las relaciones familiares, destacando el incremento de divorcios o problemas de pareja y una tendencia a la "des-funcionalización" de la familia (Díez et al., 2014), lo cual se encuentra en el mismo espacio de los resultados hallados en el presente estudio. En la línea opuesta, se encontró evidencia acerca del fenómeno de ampliación de la red social a causa de la crisis (Sánchez-Valdemoro, 2015), el cual también corrobora nuestros resultados, a pesar de que no se obtuvo evidencia acerca de la posición de apoyo que puede tomar la familia.

Con respecto a los hallazgos que relacionan el compromiso de la salud en relación a la situación socioeconómica en la que se encuentran los protagonistas, encontramos evidencias que corroboran dichas afirmaciones. Anteriormente se mencionaron estudios recientes, propios de terapia ocupacional, como son la investigación de Sánchez-Valdemoro (2015) o Van Bruggen (2014), en los que se corroboran los hallazgos de este estudio acerca de las consecuencias negativas en la salud y desempeño ocupacional de las personas que se encuentran en situación de empobrecimiento y riesgo de exclusión social en el contexto de la sociedad española. Además, se hallaron estudios elaborados en terapia ocupacional, que coinciden con lo anteriormente expuesto y relacionan estos hechos con los conceptos de privación, alienación y desequilibrio ocupacional (Moruno y Fernández, 2012), como consecuencia de factores políticos, económicos y sociales externos a la persona (Cerdeña 2015).

Sobre los resultados referentes a la mortalidad, se encontró evidencia, como es el caso de la investigación mencionada anteriormente en este estudio de Fowler et al. (2015), sobre el incremento de suicidios en EEUU a consecuencia de la crisis de vivienda. En el contexto español, hemos encontrado evidencia sobre esta situación, derivado de un empeoramiento de la salud mental de aquellas personas que se encuentran en situación de extrema pobreza, entre las que se encuentran aquellas personas que han vivido o se encuentran en proceso de desalojo (Menéndez et al., 2013). La vivencia de esta situación deriva en el empeoramiento de la condición de salud mental, predominando los episodios de depresión, sentimientos de rabia, tristeza o dependencia a fármacos y tóxicos, entre otros. Al margen de la mortalidad por suicidio, se obtuvo evidencia que relaciona la situación de pobreza con un empeoramiento de salud, debido a la disminución de recursos socioeconómicos (Cerdeña, 2015). 
Dentro de esta relación entre pobreza, desalojos y salud, debemos destacar las consecuencias en la salud mental de esta situación socioeconómica, ya que este resultado emergió en la mayor parte de narraciones de los participantes. Dentro de la evidencia científica producida en el ámbito de la ciencia de la ocupación, encontramos estudios que hacen referencia al concepto de malestar postmoderno acuñado por Bauman y Giddenes (1995), en el cual se engloban aquellos sentimientos de fracaso, incertidumbre, malestar, en que se encuentran las personas cuyas vivencias se encuentran influenciadas por el contexto de crisis en que nos encontramos inmersos. Así, estas vivencias y sentimientos, contribuyen a aumentar la ausencia de bienestar y desarrollar la enfermedad (Arcand-Dusseault y Egan, 2015), como hemos podido comprobar en el presente estudio. Además, en los discursos de los participantes de este estudio, aparece continuamente el truncamiento de los proyectos de vida o proyectos personales a consecuencia del fenómeno de estudio, y como causa de gran parte del malestar psicológico.

Con respecto a esto, existe evidencia, como es la investigación realizada por Arcand-Dusseault y Egan (2015) que relaciona el concepto de conjunto de acciones interrelacionadas a lo largo del tiempo con la finalizad de lograr o mantener una serie de metas que fueron establecidas por el propio individuo (proyectos personales) con la ocupación, los cuales se encuentran íntimamente vinculados, debido a que las ocupaciones en las que una persona se compromete a lo largo de su vida, se encuentran en consonancia con su proyecto personal. Esta investigación también establece que ambos conceptos tienen consecuencias en la salud de las personas, a nivel físico y mental, y que desde una perspectiva acorde al concepto de justicia ocupacional (Moruno y Fernández, 2012) esta relación tiene importancia, ya que si la persona no se puede comprometer con las ocupaciones que tienen importancia desde su proyecto personal, éste se verá truncado, lo cual repercutirá en su desempeño ocupacional y salud.

Además, encontramos la relación entre las vivencias de las personas que se encuentran en esta situación, su salud y su desempeño ocupacional con los principales actores sociales que forman parte de este fenómeno: movimientos sociales o instituciones privadas que ofrecen ayuda a las personas en situación de desahucio, instituciones públicas de ayuda a personas en situación de riesgo de exclusión social y entidades bancarias.

Ahondando en esta línea, destacar el elevado número de movimientos sociales que surgieron desde el estallido de la crisis. Como principal movimiento de apoyo a las personas en situación de desahucio, encontramos "Stop Desahucios", que surge como una campaña específica de la $\mathrm{PAH}$, pero que con el 
paso del tiempo se consolida como un movimiento social propio. Existe evidencia acerca de la importancia que las acciones de estos colectivos tuvieron en este fenómeno, promoviendo la lucha y defensa por los derechos de los ciudadanos, así como mediante la creación de una nueva red de apoyo e innovación social (Cano y Extezarreta, 2014). Estos hallazgos se corresponden con lo reflejado en nuestro estudio, en la que todos los participantes reconocieron la encomiable labor de este movimiento, haciendo especial hincapié en la esfera de apoyo emocional que ofrecen. Además, en el trabajo realizado por la PAH, en colaboración con el Observatori Decrets Econòmics Socials i Culturals (in extenso DESC) (Plataforma de Afectados por la Hipoteca, Observatorio DESC, 2013), se hace un repaso a las diferentes acciones, desde el plano legal, que lleva a cabo este movimiento, y se hace un estudio de las respuestas institucionales en cuanto al fenómeno de los desahucios, teniendo en cuenta la esfera legal de este fenómeno.

Así, se contemplan estas acciones, que se vieron reflejadas en nuestro estudio, como una violación de diferentes derechos regidos en la legislación nacional e internacional vigente con respecto a la vivienda, como son el artículo 47 título 1 de la constitución española (1978), sobre el derecho a la vivienda digna. Destacar que la Organización de las Naciones Unidas (in extenso ONU) emitió dentro de su programa ONU-Hábitat (2010) un informe acerca del derecho a una vivienda adecuada, recogido la Declaración Universal de los Derechos Humanos de 1948 y en el Pacto Internacional de derechos Económicos, Sociales y Culturales de 1966. Basándose en estos dos documentos, la ONU informa de que las prácticas tales como los desahucios son acciones que violan estos derechos y otros derechos humanos que se encuentran interrelacionados, y que los gobiernos no sólo deben evitarlas, sino que deben ofrecer alternativas habitacionales a la población que tenga algún problema en el acceso o mantenimiento de su derecho de tenencia, así como controlar las acciones de las entidades bancarias para evitar la especulación en torno a la vivienda. En esta línea se encuentra la categoría correspondiente a las acciones de las entidades públicas y bancarias. Por un lado, aparece el desamparo que sienten los ciudadanos respecto a la preservación de sus derechos más básicos, tanto por parte de las instituciones públicas, vinculadas con el gobierno, como por las entidades bancarias. Con el proyecto La realidad del mercado del crédito no hipotecario en España, la Asociación de Usuarios de Bancos, Cajas y seguros (in extenso ADICAE) junto con la Agencia Española de Consumo, Seguridad Alimentaria y Nutrición (in extenso AECOSAN) (2015) emitieron dos informes, producto de sus trabajos de investigación sobre el crédito hipotecario, y de cómo el sobreendeudamiento de la población española, a causa de la emi- 
sión descontrolada de créditos basura, tuvieron repercusiones en ésta. También se hace mención a aspectos que se reflejaron en este trabajo, como son la subcontratación de empresas de presión y reclamación de cobro, así como la formación de "listas negras" o "registros de morosos", que violan los derechos de las personas endeudadas con la entidad, y repercuten en su salud y vida diaria, como se reflejó en nuestro estudio.

Desde la posición de la terapia ocupacional con respecto a los derechos humanos, establecida por la World Federation Of Occupational Therapists (in extenso WFOT) (2006), tiene una gran importancia considerar la violación de los mismos que produce esta situación, ya que existen una serie de factores, entre ellos la pobreza, que compromete los derechos ocupacionales de la personas y, por tanto, su acceso al compromiso ocupacional. Por ello, en el citado documento se propone identificar estas situaciones de injusticia, incrementar la concienciación sobre éstas situaciones y trabajar en colaboración con los principales actores sociales para revertirlas y evitarlas.

Por otro lado, nos encontramos con las instituciones privadas de ayuda a personas en situación social, entre las que se encuentra Cáritas. En el informe emitido por el Equipo de Estudios de Cáritas española (2013) sobre el empobrecimiento y la desigualdad social en el contexto español, se encuentran varios datos que ratifican los resultados de nuestro estudio, sobre todo en dos puntos de ese documento: en primer lugar, se hace mención al creciente empobrecimiento y crecimiento de la desigualdad social en España, llevando a familias normalizadas a una situación de exclusión social tras el estallido de la burbuja inmobiliaria. Así, se menciona que la mayor parte de personas que se atienden en Cáritas son personas que previamente se encontraban en situación de exclusión social (casos cronificados), pero también familias para las cuales esta situación es nueva, destacando el perfil de mujer de mediana edad. En segundo lugar, también se trata la ineficacia de los Servicios sociales. La mayor parte de personas que acuden al recurso privado, vienen derivadas de los recursos públicos, en algunos casos por insuficiencia de los mismos y, en otros, porque éstos no pueden dar respuesta a todos los casos, hecho que se vieron reflejado en los diferentes discursos de los participantes del presente estudio.

\section{Futuras líneas de investigación}

Proponemos ampliar los conocimientos desde la ciencia de la ocupación, acerca de cómo, en este contexto, los diferentes factores políticos, históricos, culturales o socioeconómicos, ejercen influencias y provocan repercusiones significativas en la vida diaria y salud de las poblaciones. En nuestra opinión, los resultados logrados, deberían ser tenidos en cuenta con el fin de lograr la aper- 
tura de nuevos campos de práctica profesional, desde una perspectiva acorde con la acción en la comunidad de la terapia ocupacional, que se enmarca en la emergencia de ésta como fenómeno social (Galheigo y Simó 2012)

\section{Limitaciones del estudio}

Falta de evidencia científica con respecto a algunos de los temas que emergieron como resultado de este trabajo, sobre todo en la disciplina de terapia ocupacional al tratarse de un tema novedoso e inexplorado.

\section{CONCLUSIÓN}

En consonancia con los objetivos planteados, y a la luz de los resultados afirmamos que el constructo vivencial de desempeño ocupacional de las personas que se encuentran en esta situación se ve influenciado por varios factores: cambios en sus contextos/entornos, acciones de todos los actores sociales implicados en esta situación, modificaciones que estas personas sufren en su desempeño ocupacional y en su salud como consecuencia del fenómeno a escala global. En cuanto a la exploración del desempeño ocupacional y el equilibrio del mismo, se ha corroborado la afectación que los informantes percibieron, debido a las diferentes repercusiones en los contextos personales, temporales, entornos físicos y sociales, así como en las distintas áreas de la ocupación, elementos clave en el desempeño ocupacional y su equilibrio. Por último, destacar que la confluencia de todos los factores anteriormente mencionados, de carácter externo a la persona e impulsados por situaciones de índole política y económica, tuvieron como resultado una situación de privación ocupacional que mella la salud de la población.

\section{AGRADECIMIENTOS}

Los autores no tienen conflicto de intereses y detallan no haber recibido financiación alguna para el desarrollo de esta investigación

\section{REFERENCIAS BIBLIOGRÁFICAS}

Adell, M., Lara, A. y Mármol, E. (2014). La PAH: Origen, evolución y rumbo. Anuario 2013. Bizkaia: Fundación Betiko, Recuperado de http://docplayer.es/5146536-Lapah-origen-evolucion-y-rumbo-1.html

ADICAE, Ministerio de Sanidad, Servicios sociales e Igualdad, AECOSAN. (2015). La Realidad del crédito no hipotecario en España. Análisis económico y jurídico del crédito de consumo y los créditos rápidos. Zaragoza: ADICAE. 
American Occupational Therapy Association (2014). Occupational therapy practice framework: Domain and process ( $3^{\text {rd }}$ ed.). American Journal of Occupational Therapy, 68(Suppl 1): S1-S48. doi: 10 5014/ajot 2014682006

Arcand-Dusseault, C., y Egan, M. (2015). Occupations and personal projects: A comparison of the concepts. British Journal of Occupational Therapy, 78(5), 303-310. doi: 10.1177/0308022615578606

Arias, M.M., y Giraldo, C.V. (2011). El rigor científico en la investigación cualitativa. Investigación y Educación en Enfermería, 29(3), 500-514. Recuperado de : http://www.redalyc.org/articulo.oa?id=105222406020

AAVV (2016). Te quedarás en la oscuridad. Desahucios, familias e infancia desde un enfoque de derechos. Madrid: PAH-Madrid, Enclave y Quiteria. Recuperado de https://www.cuartopoder.es/wp-content/uploads/2016/11/Informe_PAH.pdf

Bauman, Z., y Giddenes, A. (1995). Modernidad e identidad del yo. El yo y la sociedad en la época contemporánea. Barcelona: Ediciones península/ideas.

Cano, G., y Extezarreta, A. (2014). La crisis de los desahucios en España: Respuestas institucionales y ciudadanas. Revista de Economía Crítica, 10(17), 44-57. Recuperado de http://revistaeconomiacritica.org/sites/default/files/revistas/n17/03_CanoEtxezarreta_Crisis-de-los-deshaucios.pdf

Castells, M. (2013). Redes de indignación y esperanza: los movimientos sociales en la edad de internet. Cuadernos de geografía. Revista Colombiana de Geografía, 22(2), 273-276. Recuperado de: http://www.scielo.org.com/pdf/rcdg/v22n2/v22n2a15.pdf

Cerdeña, I. (2015). Desempleo y su repercusión en la salud. TOG (A Coruña), 12 (22), 1-13. Recuperado de http://www.revistatog.com/num22/pdfs/revision1

Colau, A y Alemany, A (2012). Como hemos llegado hasta aquí: el ADN de la burbuja inmobiliaria. En: A. Colau y A. Alemany. Vidas hipotecadas. De la burbuja inmobiliaria al derecho a la vivienda. (pp. 65-72) Barcelona: Cuadriláteros de libros.

Constitución Española. [Const] de 1978. Boletín Oficial del Estado. Madrid, 29 de diciembre de 1978, núm. 311, pp 29313-29424.

De la Vega, S. (2014). La pobreza que no está en los pobres. Revista Política y Cultura, 21(41), 209-226. Recuperado de http://www.redalyc.org/pdf/267/26730752011.pdf

Díez, C., López, C., Palatucci, A., Sesé, E., y Tapiador, N., (2014). Crisis económica y disfunción ocupacional: efectos y propuestas de cambio en contexto de crisis. TOG (A Coruña), 11(20), 1-12. Recuperado de:

http://www.revistatog.com/num20/pdfs/colabl.pdf

Equipo de Estudios de Cáritas española, Observatorio de Realidad social. (2013). VIII Informe del observatorio de Realidad social: Empobrecimiento y desigualdad social. El aumento de la fractura social en una sociedad vulnerable que se empobrece. Madrid: Cáritas.

Fowler, K.A., Gladden, R.M., Vagi, K.J., Barnes, J., y Frazier, L. (2015). Increase in suicides associated with home eviction and foreclosure during the US housing crisis: findings from 16 national violent death reporting system states, 2005-2010. American Journal of Public Health, 105(2), 311-317. doi: 10.2105/AJPH.2014.301945. 
Galheigo, S., y Simó, S. (2012). Maestras de la terapia ocupacional. Sangra Galheigo: la poderosa emergencia de la terapia ocupacional social. TOG (A Coruña), 9(15), 1-41. Recuperado de http://www.revistatog.com/num15/pdfs/maestros.pdf

Gil, A., y Campuzano, P. (2014). Pobreza y Salud. Eu-topías, 4(7), 71-78. Recuperado de http://eu-topias.org/pobreza-y-salud/

Gómez, S. (2006). Equilibrio y organización de la rutina diaria. Revista Chilena de Terapia Ocupacional, 6(6), 1-11. doi: 10.5354/0717-5346.2006.111

Guba, E., y Lincoln, Y. (2002). Paradigmas en competencia en la investigación cualitativa. En Por los rincones. Antología de métodos cualitativos en la investigación social. (pp.113-45). Hermosillo: Sonora.

Hanneke, V. (2014). Abordando las desigualdades de la Terapia Ocupacional: contribuciones al programa del próximo MDG 2015 y el futuro que queremos para todos. TOG (A Coruña), 12(10), 33-49. Recuperado de http://www.revistatog.com /suple/num10/addressing.pdfs

Hernández, R. Fernández, C., y Baptista, P. (2010a). El inicio del proceso cualitativo: planteamiento del problema, revisión de la literatura, surgimiento de las hipótesis e inmersión en el campo. En: R. Hernández, C. Fernández y P. Baptista. Metodología de la investigación. (5 ed.) (pp.363-390). México: McGraw-Hill.

Hernández, R. Fernández, C., y Baptista, P. (2010b). Muestreo en la investigación cualitativa. En: R. Hernández, C. Fernández y P. Baptista. Metodología de la investigación. (5 ${ }^{a}$ ed.) (pp.392-406). México: McGraw-Hill.

Hernández, R. Fernández, C., y Baptista, P. (2010c). Recolección y análisis de los datos cualitativos. En: R. Hernández, C. Fernández y P. Baptista. Metodología de la investigación. (5 ed.) (pp 407-490). México: McGraw-Hill.

Instituto Gallego de Estadística. (2015). Execucións hipotecarias presentadas polos Tribunais Superiores de Xustiza. Datos por Comunidades Autónomas. Recuperado de: http://www.ige.eu/igebdt/selector.jsp?COD=5228\&paxina=001\&c=0205005

Instituto Nacional de Estadística. (2015). INE. Recuperado de http://www.ine.es

López, V., y Frías-Osuna, A. (2000). Concepto de salud pública. En: A. Frías-Osuna. Salud pública y educación para la salud. (p.3-14). Barcelona: Masson,

Mejía, LM. (2013). Los determinantes Sociales de la Salud: base teórica de la salud pública. Revista Facultad Nacional de Salud Pública, 31(1), 28-36. Recuperado de http://www.scielo.org.co/pdf/rfnsp/v31s1/v31sla03.pdf

Mangot, L. (2013). La plataforma de Afectados por la Hipoteca. De la crisis a la Estafa. Del prozac al empoderamiento. Clivatge. Revista d'estudis i testimonis sobre els conflictes i els canvis socials, 2(2), 56-88. Recuperado de http://revistes.ub.edu/index.php/clivatge/article/view/10021

Menéndez, F, Márquez I., Gay E., Armañanzas, G., Angosto, T., Gómez, C.,... Filgueira, J. (2013). Suicidios, desahucios y más recortes. Revista Norte de salud mental, 11(45), 7-9. Recuperado de https://dialnet.unirioja.es/descarga/articulo/4222059.pdf

Morrison, R.J., Olivares, D.A., y Vidal, D.M. (2011). La filosofía de la Ocupación humana y el paradigma social de la ocupación. Algunas reflexiones y propuestas 
sobre epistemologías actuales en Terapia Ocupacional y Ciencias de la Ocupación. Revista Chilena de Terapia Ocupacional, 11(2), 1-18. doi: 10.5354/0717-5346.2011.17785

Moruno, P., y Romero, D.M. (2003). Definición de la terapia ocupacional. En: P. Moruno y D.M. Romero. Terapia Ocupacional: Teoría y Técnicas. (pp 41-53). Barcelona: Masson.

Moruno, P., y Fernández, P. (2012). Análisis teórico de los conceptos privación, alienación y justicia ocupacional. TOG (A Coruña), 9(monog. 5), 44-48. Recuperado de http://www.revistatog.com/mono/num5/teorico.pdf

Núñez, J.M. (2012). Estudio longitudinal de las familias afectadas por el desempleo: relaciones familiares, economía y salud. INFAD Revista de psiquiatría y psicología del niño y del adolescente, 1(2), 361-369. Recuperado de https://dialnet.unirioja.es/servlet/articulo? codigo $=5229514$

Nuño, J. (2014). Del "que se vayan" al "no nos representan". Respuestas de la crisis económica en España y Argentina. Ágora, 1(2), 101-16. Recuperado de http://www.e-revistes.uji.es/index.php/kult-ur/article/view/1503

Okuda, M., y Gómez-Restrepo, C. (2005). Métodos en investigación cualitativa: triangulación. Revista Colombiana de Psiquiatría, 34(1), 118-24.

Oficina de Alto Comisionado para los Derechos Humanos, Organización de las Naciones Unidas. (2010). ONU Hábitat: El derecho a una vivienda adecuada. Génova: ONU.

World Federation of Occupational Therapists (WFOT). (2006). Position Statement of Human Rights. Australia: WFOT

Plataforma de Afectados por la Hipoteca, Observatorio DESC. (2013). Emergencia habitacional en el estado Español, la crisis de las ejecuciones hipotecarias y los desalojos desde una perspectiva de derechos humanos. Barcelona: Plataforma de Afectados por la Hipoteca. Recuperado de http://www.afectadosporlahipoteca.com/2013habita cional/informe-emergencia-habitacional/

Plataforma de Afectados por la Hipoteca, Obervatori DESC. (2014). Libro verde de la PAH: Una guía básica sobre la PAH. Barcelona: Plataforma de Afectados por la Hipoteca.

Real Academia de la lengua Española (2015). Diccionario de la Real Academia de la lengua Española. Madrid: RAE.

Ruíz, J.L. (2012). Control de calidad de la metodología cualitativa. En: J.L. Ruíz Olabuenaga. Metodología de la investigación cualitativa. (pp 83-116). Bilbao: Deusto.

Salgado, A.C. (2007). Investigación cualitativa: Diseños, evaluación del rigor metodológico y retos. Liberabit (Lima). 13(13), 71-78. Recuperado de:

www.redalyc.org/articulo.oa? $\mathrm{id}=68601309$

Sánchez-Valdemoro, S. (2015). Crisis económica y vida diaria: elementos, fenómenos y políticas. TOG (A Coruña), 12(22), 1-14. Recuperado de:

http://www.revistatog.com/num22/pdfs/colab2.pdf

Sequera, J (2011). Del movimiento vecinal a las movilizaciones por una vivienda digna en Madrid. De la necesidad hecha derecho al derecho hecho necesidad. 
Nómadas, Revista Crítica de Ciencias Sociales y Jurídicas, 29(1), 1-17. Recuperado de http//www.redalyc.org/articulo.oa?id=18118941025

Talavera, M.A. (2012). El valor del objeto en lo cotidiano. TOG (A Coruña), 9(16), 1-12. Recuperado de http://www.revistatog.com/num22/pdfs/colab2.pdf

Towsend, E., y Wilcock, A.A. (2004). Occupational justice and client-centred practice: a dialogue in progress. Candian Journal of Occupational Therapy, 71(2), 75-87. doi:

$10.1177 / 000841740407100203$

Vargas, I. (2012). La entrevista en investigación cualitativa: nuevas tendencias y retos. Revista de Calidad de Educación Superior, 3(1), 119-139. Recuperado de https://dialnet.unirioja.es/servlet/articulo? codigo $=3945773$

Wilcock, A.A. (2006). An Occupational perspective of health. United States Of America: SLACK Incorporated.

\section{BREVES NOTAS BIOGRÁFICAS}

IRENE PAZOS-CARRO: Graduada en Terapia Ocupacional, Universidade de A Coruña. Terapeuta Ocupacional en Residencia Geriátrica "O Fogar de Gandarío". Estudiante Grado en Psicología

e-mail de contacto: irenepazos1@hotmail.com

ANA-ISABEL SOUTO-GÓMEZ: MSc. MEd. Graduada en Terapia Ocupacional y Graduada en Trabajo Social. Coordinadora técnica y Trabajadora social de la Federación Galega de Esclerose Múltiple (FEGADEM). Coordinadora de la secretaría, comité redactor y de difusión de TOG (A Coruña) www.revistatog.com http://orcid.org/0000-0001-7907-0877

e-mail de contacto: anasogo@hotmail.es

MIGUEL-ÁNGEL TALAVERA-VALVERDE: PhD. MSc. OT. Profesor e investigador de la Universidade da Coruña, Unidad de investigación INTEGRA Saúde, Departamento Ciencias de la Salud (España). Miembro del Grupo de Investigación SINERGIA, Universidad del Valle (Colombia). Terapeuta ocupacional en Xerencia de Xestión Integrada de Ferrol (A Coruña). Director de TOG (A Coruña) www.revistatog.com http://orcid.org/0000-0002-9817-373X e-mail de contacto: miguel.angel.talavera.valverde@udc.es

Recibido: 30-06-2017

Aceptado: 28-09-2018

\section{(c) (P) Licencia Creative Commons Reconocimiento (CC BY 4.0)}




\title{
ENTRE "CÁRITAS" Y "TRABAJAR DEMASIADO”: ETNIA, GÉNERO Y RELIGIÓN EN LA EXPERIENCIA MIGRATORIA DE PUEBLOS ORIGINARIOS ECUATORIANOS EN ESPAÑA \\ BETWEEN "CÁRITAS" AND "WORKING TOO MUCH": ETHNICITY AND RELIGIOSITY IN THE MIGRATION EXPERIENCES IN SOUTHERN ECUADOR AND CENTRAL-EASTERN SPAIN
}

\author{
Rocío Pérez Gañan \\ Universidad Nacional de Quilmes (UNQ), Argentina. \\ rocio.ganan@unq.edu.ar
}

\begin{abstract}
Cómo citar / citation
Pérez, R. (2018) "Entre "Cáritas" y "trabajar demasiado": etnia, género y religión en la experiencia migratoria de pueblos originarios ecuatorianos en España". OBETS. Revista de Ciencias Sociales, 13(2): 621-644.

doi: 10.14198/OBETS2018.13.2.07
\end{abstract}

\section{Resumen}

El presente artículo ha tratado de vincular tres espacios geográficos específicos: la sierra del austro ecuatoriano, la provincia de Madrid y el levante español, con un espacio compartido de significado: la afiliación y las prácticas religiosas; y un espacio identitario minoritario y heterogéneo: lo indígena. En estos lugares "intersituados", los procesos migratorios han posibilitado el contacto y la circularidad de creencias y prácticas religiosas de las y los indígenas ecuatorianos a ambos lados del Atlántico, incidiendo, tanto en los territorios del país de destino como en sus lugares de origen a través de la constitución de familias -e incluso comunidades- transnacionales y de los procesos de movilidad circular que desarrollan. A partir del análisis de fuentes bibliográficas, información estadística y datos etnográficos, se ha profundizado en el estudio de la afiliación, las representaciones y prácticas religiosas de las personas indígenas migrantes en el país de destino (España) y en el proceso de integración en el retorno al país de origen (Ecuador) con la intencionalidad de conocer 
los procesos de redefinición de identidad religiosa que están teniendo lugar en los espacios personales, familiares y sociales de las personas indígenas migrantes y migrantes-retornadas del austro ecuatoriano dentro del ámbito específico de las circularidades migratorias Ecuador-España.

Palabras clave: migración; transnacionalismo; etnicidad; género; afiliación religiosa, prácticas religiosas.

\begin{abstract}
This article attempts to link three specific geographical spaces the mountainous regions of southern Ecuador, the province of Madrid, and eastern Spain -with a shared space of meaning- the affiliation and religious practices and a minority and heterogenous space of identity: indigenous culture. In these "intersituated" places, migratory processes have allowed the contact and circularity of religious practices and beliefs of indigenous Ecuadorians between both sides of the Atlantic, affecting both the destination country and the places of origin through family makeup and even the making of communities. By analyzing the relevant literature, statistical information, and ethnographic data, this article has delved into the study of affiliation, representations, and religious practices of indigenous migrants in the destination country (Spain) and the process of integration upon returning to the country of origin (Ecuador), all with the intention of understanding the processes involved in redefining religious identity, which are taking place in individual, family, and social spaces in the communities of indigenous migrants.
\end{abstract}

Keywords: migration; transnationalism; ethnicity; gender; affiliation; religious practices.

\title{
INTRODUCCIÓN
}

Ahora nos hemos descuidado un poco, nos hemos acostumbrado a trabajar como en Europa, es verdad, porque nosotros antes no trabajábamos de verdad, tres o cuatro horitas, no más, pero ahora trabajamos de verdad, diez horas, ocho horas... y eso, a veces, nos dificulta para ir a la misa [...] pero nosotros tenemos la religión católica que nadie puede cambiar.

(Rosa, indígena saragura retornada, 57 años, Saraguro, 2014)

Rosa, indígena de la etnia Saraguro, en el austro ecuatoriano, narraba su trayectoria migratoria hacia España (donde vivió ocho años) como una experiencia sobre la que aprendió mucho, especialmente "a trabajar de verdad", hecho que repetía constantemente en la entrevista mantenida en su comercio de la plaza central de la localidad de Saraguro, en la provincia de Loja, Ecuador. Este aumento de las horas laborales, primero en España y después en el retorno a su lugar de origen, había ocasionado un alejamiento de ciertas prácticas cotidianas que mantenían antes de la migración. Una de estas prácticas había sido acudir a los ritos católicos de manera habitual. Rosa es viuda y es la principal sus- 
tentadora del hogar. Ella abre su comercio pronto en la mañana para aprovechar la visita de las y los turistas que se acercan cada día a conocer el pueblo. La mayoría de turistas que pasan por su negocio son norteamericanos aunque como ella señala "hay de todo". Antes de emigrar a España Rosa no tenía un horario fijo en su negocio de artesanías ni trabajaba tantas horas pero eso ha cambiado tras su viaje. Ahora nunca cierra antes de las seis de la tarde. Su volumen de trabajo, sus empleados y sus ganancias han aumentado considerablemente con este cambio de horario y con "la forma de trabajar", algo que no olvidaba señalar. Rosa ha diversificado su actividad y ya no solo hace venta directa sino que tiene acuerdos de envíos a otros negocios y a otras ciudades como Cuenca y Zamora en Ecuador. Respecto a la religión, Rosa es católica, aunque dice que hace tiempo que no va a misa, solo a algunas, ya que el volumen de trabajo ocupa la mayor parte de sus días, incluso los domingos. Sin embargo, se siente profundamente católica, creencias que la migración a España no ha cambiado, tan solo, como ella cuenta, han cambiado las formas. Rosa continua hablando a Dios en la intimidad, le pide bendiciones para el negocio, su familia y sus amigos y amigas. También le agradece por todo lo que ha conseguido hasta hoy y porque toda su familia goza de buena salud. Ella está segura de que desde la intimidad "Diosito" también la escucha y que aunque ella respeta a las y los que van a todas las actividades de la iglesia, para ella ya no son tan necesarias.

Al igual que Rosa, muchas de las personas entrevistadas señalaban vivencias similares en su migración hacia España en relación a sus prácticas religiosas. Estas tuvieron que ser resituadas mayoritariamente en sus espacios privados (hogar) ante la imposibilidad de acudir a los centros de culto, entre otras cosas, por el amplio horario laboral. A pesar de ello, en las narrativas presentes se expresaba una afirmación en las creencias católicas en el sentido de haber resultado un apoyo fundamental para superar las "dificultades del viaje". Dificultades que atravesaban, también, su identidad étnica y su género. Para todas las personas entrevistadas su condición de indígenas ha transitado por algún espacio de rechazo, minusvalorización, discriminación y explotación en España que recuerdan con tristeza y contraponen a momentos de experiencias positivas que consideran, no obstante, son muy superiores en número. Asimismo, ser mujer va a añadir un nivel más de exclusión en cuanto que va a estar sujeta a unos roles tradicionales fuera y dentro del propio grupo que definen los lugares adecuados y las prácticas que estas mujeres migrantes deben ocupar y hacer.

A su llegada a España, las y los migrantes entrevistados señalan que, además de las redes sociales que se activaron durante el proceso migratorio, el soporte 
que les brindó la fe y la "encomendación a Dios" fue un apoyo fundamental para superar las vicisitudes del viaje en lo personal, lo laboral y lo social, especialmente en sus inicios. En este contexto muchas personas recuerdan y citan la importancia del apoyo recibido a través de la organización Cáritas ${ }^{1}$ (Confederación Oficial de las Entidades de Acción Caritativa y Social de la Iglesia Católica en España) entidad que además de ser una organización conocida previamente en Ecuador les facilitó el acceso a comida, ropa y servicios sociales. A pesar de que Cáritas no brinda un apoyo propiamente religioso sino de ayuda social es fuertemente asociada, en las narrativas, a la iglesia católica.

Este breve marco presentado a modo de introducción revela una serie de interseccionalidades comunes en la migración de Saraguros y Cañaris hacia España que fueron analizadas durante la investigación con el objetivo de conocer las dinámicas de "afiliación" religiosa (Durkheim 2008 [1912]), "representaciones sociales" y "prácticas" (Moscovici 1989) que se conforman. Para alcanzar este objetivo general se operacionalizó el estudio a través de dos objetivos específicos enfocados en conocer los discursos que estas personas migrantes tenían respecto a "lo religioso" (el primero de ellos) y a la observación de las prácticas cotidianas en espacios de trabajo y culto abierto (el segundo). Las hipótesis de partida señalaban que la migración a un país católico (practicante o no practicante) como España facilitaba una continuidad en la afiliación de las creencias en origen. Asimismo, la fuerte presencia de Cáritas (organización humanitaria de la iglesia católica) como entidad de apoyo en los primeros momentos fortalecía esta continuidad. Por otra parte, las hipótesis sugerían la existencia de transformaciones en las creencias y en las prácticas derivadas de los procesos de integración en destino (culturales y, especialmente, trabajo) que eran reproducidas, asimismo, en el retorno al país de origen.

Para mostrar los resultados obtenidos en la investigación y la verificación de las hipótesis de partida, el presente artículo se ha organizado en varios apar-

${ }^{1}$ Cáritas Española es una confederación formada por setenta Cáritas diocesanas de España y tres instituciones: Asociación San Vicente de Paul, Conferencia Española de Religiosos (CONFER) y Federación Española de Religiosos Sociosanitarios. Fue creada en 1947 y tiene personalidad jurídica propia, tanto eclesiástica como civil. Entre sus objetivos destacan la promoción y coordinación de la solidaridad de la comunidad cristiana y la ayuda a la promoción humana y al desarrollo integral de la dignidad humana de todas las personas que se encuentran en situación de precariedad. La mayor parte de su financiación proviene de fondos privados (40.015.262, presupuesto para 2017). La financiación pública corresponde a la administración autonómica, a la central, a la local y a la procedente de la Unión Europea (38.220.931, presupuesto para 2017). Las aportaciones de las Cáritas Diocesanas representan un $1.54 \%$ del total de la financiación (1.234.722, presupuesto para 2017) (Cáritas 2017). 
tados: un marco referencial sobre migración, religiosidad y etnicidad donde se sitúan, interrelacionadamente, el estado de la cuestión, el marco conceptual y el marco teórico general; un apartado donde se contextualiza la investigación; una sección donde se presenta la metodología utilizada y la pertinencia de la misma; y un bloque en el que se exponen los resultados más relevantes. Finalmente, a modo de conclusión, se han sintetizado las ideas más relevantes expuestas a lo largo del texto.

\section{MARCO REFERENCIAL. LA COMPLEJA INTERSECCIONALIDAD DE LOS ESTUDIOS MIGRATORIOS, LA RELIGIOSIDAD, LA ETNICIDAD Y EL GÉNERO}

En los últimos años estamos asistiendo a un incremento en relación al estudio de las relaciones existentes entre migración y religión que responde a un interés por profundizar en las características particulares -muchas hasta ahora invisibilizadas-, que esta interrelación presenta (Stepick 2006; Odgers 2006, 2014; Martínez-Ariño et al. 2011). Diversos autores y autoras han señalado el proceso migratorio como un importante factor de cambio en las representaciones y prácticas religiosas (Kurtz 1995; Odgers 2006, 2014; De la Torre y Gutiérrez 2007; Levitt y Jaworsky 2007; Mallimaci 2016; Fréderiks y Nagy 2016; Rivera Sánchez, Odger Ortiz y Hernández Hernández 2017) destacando la necesidad de "continuar el análisis de la interrelación de esos campos, sistematizando los trabajos ya existentes y construyendo nuevas perspectivas de análisis" (Odgers 2006: 400). Aunque buena parte de la literatura existente se ha centrado en analizar el caso entre la población migrante latinoamericana (mexicana concretamente) a Estados Unidos (Hervieu-Leger 1996; Bastian 1997; Espinosa 1999; Durand y Massey 2001; O'Connor 2001; De la Torre y Gutiérrez 2007; Hernández 2007; Levitt 2003; Galaviz, Odgers Ortiz, y Hernández, 2009; Odgers 2006, 2014; Romizi, 2014; Rivera Sánchez, Odger Ortiz y Hernández Hernández 2017), existen análisis relevantes fuera de este contexto específico enfocados en otros flujos migratorios como son los trabajos de Soper y Fetzer (2007), Maussen (2004) y Saint-Blancat (2002) sobre la diáspora islámica y su inserción en países de destino no islámicos o los de Abdelmalek Sayad (1999), en relación al "quedarse" y/o "retornar" que viven las poblaciones argelinas en Francia; o los recientes trabajos de Mallimaci (2016) sobre la migración y prácticas religiosas bolivianas en Ushuaia, Argentina.

En el proceso migratorio, cuando abordamos cuestiones de identidad indígena es necesario aproximarse a su análisis tanto como una realidad de vivencia personal como una realidad colectiva teniendo en cuenta que se sitúa en la encrucijada de lo individual y lo social y es en esta confluencia en la que cobra 
sentido interrelaciondamente lo biográfico, lo social, lo histórico y lo cultural. Al ponerse en juego elementos del pensamiento y la conducta, por un lado, y las narrativas, creencias y símbolos por otro, convergen y se (re)construyen las historias: las propias y las colectivas. Como realidad de vivencia personal, para Giddens, la identidad "es el resultado de un proceso tanto micro como macrosocial, en el que existe una relación dialéctica entre ambos niveles, y en el que la identidad del Yo es la manera en que nosotros mismos nos percibimos de una manera refleja en función de nuestra biografía" (Giddens 1995: 294). Es decir, construimos nuestro relato en relación a nuestros espacios. Como realidad colectiva para Castells la identidad es "el proceso de construcción de sentido atendiendo a un atributo cultural, o un conjunto relacionado de atributos culturales, al que se da prioridad sobre el resto de las fuentes de sentido. Para un individuo determinado o un actor colectivo puede haber una pluralidad de identidades" (Castells 1998: 28). De este modo, creamos categorías que construyen "comunidades imaginadas" (Anderson 1991, citado en EstebanGuitart, Vila y Bastiani, 2010: 3) que generan un sentido de pertenencia o ausencia. Precisamente, la confluencia de "comunidades imaginadas" en la biografía personal, es decir, de distintas categorías o grupos sociales presentes en la identidad, nos lleva a sugerir el concepto de identidad híbrida, múltiple o compleja. Entendiendo por "identidad híbrida, múltiple o compleja" la puesta en consideración de distintos atributos culturales en el proceso de construcción de sentido existencial. Por ejemplo, "soy hablante del tsotsil, chiapaneco y a la vez mexicano, con fuertes raíces católicas" (Esteban-Guitart, Vila y Bastiani, 2010: 3). En esta definición confluyen, a la vez, de un modo múltiple e híbrido, la referencia a cuatro atributos culturales: la lengua, el estado o región, el grupo nacional y la adscripción religiosa.

No obstante, estas interrelaciones de la biografía y las comunidades imaginadas no se (re)producen sin una interacción de conflicto, como muchas veces las categorías multi, pluri o híbrido parecen reflejar (García Canclini, 1999). Existen relaciones de poder, contradicciones y estrategias situacionales que van a actuar en mayor o menor medida, en una dirección o en otra y/o en un interés o en un beneficio concreto personal o social. Para Moscovici (1963), estas comunidades imaginadas van a generar unas representaciones sociales creadas con un propósito concreto de posicionarse y comunicarse a través de este posicionamiento. Esta posición y la comunicación a través de ella posibilita que las personas procesen y transformen: "las experiencias en modelos internos a través de los símbolos que sirven como guías para la acción futura. Así mismo, a través de los símbolos se dan significado, forma y continuación a las experiencias" (Moscovici 1963, citado en Navarro 2002: 211). Este sistema de 
elaboración y funcionamiento de una representación social se (re)produce, según Moscovici, a través de dos procesos: "La objetivación y el anclaje, que muestran interdependencia entre la actividad psicológica y sus condiciones sociales de ejercicio. El anclaje se refiere al enraizamiento social de la representación y de su objeto, la intervención de lo social se traduce en el significado y la utilidad que le es conferida" (Ibídem).

En este sentido, a las poblaciones saraguras y cañaris de Ecuador al llegar a España son categorizadas mediante una representación, por un lado, como parte de una etnicidad esencialmente "originaria" que les mantiene como "los otros", los que están "allí" y, por otro, como migrantes económicos de bajo poder adquisitivo, católicos (como consecuencia de la conquista de América) e inmersos en procesos de asentamiento donde interrelacionan sus tradiciones con la incorporación de prácticas globalizadas o con las circularidades migratorias: con su llegada "aquí". Siguiendo los postulados de Silvia Rivera Cusicanqui (2010) estas "comunidades imaginarias" y estas biografías representadas nunca podrán converger en una condición de equidad y equilibrio, sino que, más bien, mantendrán una relación en conflicto dependiendo del contexto en el qué y en el para qué se (re)produzcan.

Así, en la migración van a confluir una multitud de procesos internos y externos interdependientes (Massey 2004) que "moldearán" las identidades en grados, niveles y procesos cambiantes y "subobjetivos" y van a conformar las distintas representaciones de estas identidades rechazando la clasificación de los sujetos en categorías universales e inmutables (Butler 2002 [1993]). En este sentido, aunque la afiliación religiosa (Durkheim 2008 [1912]) que saraguros y cañaris profesan en Ecuador es católica y al llegar a España se mantiene por factores socio-culturales compartidos que la refuerzan (idioma, religión, social), las representaciones sociales y las prácticas que despliegan en relación a esta afiliación va a sufrir adaptaciones en relación a la "objetivación y anclaje" señalada por Moscovici (1989), donde la "subobjetividad" y la "necesidad de trabajar" se erige como uno de los principales elementos transformadores.

Los procesos migratorios, atravesados por etnicidad e interculturalidad en España han sido abordados por varios autores como Cruz Zúñiga (2010, 2014), López y Oso (2007) y Sánchez y Cruz (2012), trabajos donde a pesar de que la religiosidad no es el objeto de estudio propiamente dicho sí se hace referencia a su importancia en la generación y mantenimiento de comunidad. De forma específica, la religión se hace presente en los trabajos sobre la pluralidad religiosa en España de García (2008), Pérez-Agote y Santiago (2009), y Pérez Agote (2016), sin embargo, estos trabajos no profundizan en la interrelación de esta religiosidad con la identidad indígena y los procesos migratorios (excepto 
García (2008), para este último caso). Este marco en España revela la escasa obra bibliográfica existente sobre la interrelación de los procesos migratorios con las diversas identidades que los atraviesan.

Asimismo, la complejidad aumenta al tener en cuenta que el género atraviesa todas estas cuestiones de la identidad. En el marco actual de las migraciones Sur-Norte la incorporación de las mujeres al mercado laboral, la cualificación y el envejecimiento de la población han generado "la creación de nichos de trabajo de baja aceptabilidad para los nacionales" (Tapia 2011:121). Una gran parte de estos nichos están relacionados con el campo, los cuidados y los trabajos domésticos, espacios que van a ser ocupados por estas mujeres migrantes indígenas y que van a visibilizar toda una estructura de precariedad, informalidad, desigualdad y estrategias de externalización del trabajo (Morcillo 2012; Tapia 2011; Ariza 2007; Pérez-Orozco 2006). Las mujeres, además de su inserción laboral son tradicionalmente las encargadas de la reproducción de la cultura. Desde esta perspectiva esta migración de mujeres conforma elementos y procesos que pueden posibilitar, entre otras cosas, cambios en las relaciones de género -incremento del número de mujeres jefas de hogar, pérdida del modelo hegemónico de masculinidad, cambios en los roles laborales, sociales, morales, e incluso en las creencias y prácticas religiosas- (Herrera 2005; Yeates 2005; Darvishpour 2003). A pesar de que las narrativas y categorías de análisis patriarcales han enterrado buena parte de la participación de las mujeres, es innegable su importancia, al mismo tiempo, en la reproducción biológica y cultural del grupo étnico dentro de su grupo y en las sociedades en las que se asientan jugando roles destacados en ciertas formas de culto a los antepasados, liderazgos políticos, organizativos, en la producción de comida tradicional (aspectos claves en el mantenimiento de la identidad indígena) y en la vital participación de las mujeres en los espacios de encuentro e interacción de las representaciones sociales del país de origen y de destino (Torres 2004: 2).

En el marco referencial anteriormente expuesto se refleja al mismo tiempo la dificultad y la riqueza al tratar de analizar la intersección de las variables etnia-clase-género-religión en el marco de las migraciones transnacionales.

\section{CONTEXTUALIZACIÓN: MIGRACIÓN Y RETORNO DE SARAGUROS Y CAÑARIS HACIA ESPAÑA}

Las migraciones como estrategias de adaptación y supervivencia han acompañado a los pueblos originarios hasta la actualidad conformando espacios y dinámicas de etnicidad y frontera que han sido objeto de estudio de notable interés para muchas y muchos investigadores (Leach 1954; Barth 1976; Gluckman 
1987; Kurtz 1995; Fredericks y Nagy, 2016). En relación a los pueblos saraguro y cañar ${ }^{2}$ del austro ecuatoriano, estos procesos migratorios comienzan a hacerse visibles a partir de los trabajos de Tual (1979) y Belote (1998 [1984]), quiénes recogen extensamente las características de la migración laboral interna a principios del siglo XX en las que, frecuentemente, entre los saraguros se daba una gran cantidad: [...] de viajes para trabajar en las minas de Zaruma (Bacacela 2003) e incursiones en la zona del Oriente, Yacuambi-Zamora, para formar pastizales y destinarlos a la cría de ganado vacuno" (Belote 1998: 282381; Stewart, Belote y Belote 1976: 377-381; Belote y Belote 1985: 160-177). Asimismo, Bacacela (2003) narra cómo "algunos de los que fueron a Zaruma, Machala y Portovelo cambiaron su etnicidad, se casaron en esas localidades y nunca regresaron a su área de origen" (Belote 1998:450 [1984]).

Además de esta migración interna, las y los saraguros han protagonizado en la década de los noventa una importante migración laboral hacia el exterior

\footnotetext{
${ }^{2}$ El pueblo Saraguro se asienta en las provincia de Loja y Zamora Chinchipe en el Austro ecuatoriano. Las lenguas principales son el kichwa y el español. Su población constituye el 1,68\% (aproximadamente 55.000 habitantes) de la población indígena de Ecuador que constituye, a su vez, un 7, 03\% del total de la población del país (14.483.499 personas). Se estimada que las cifras oscilan entre 45.000-60.000 habitantes, organizados en alrededor de 183comunidades. Su estructura organizativa se rige bajo la concepción comunitaria tradicional sustentada en principios de solidaridad y reciprocidad, pero con nuevos mecanismos de cohesión de corte capitalista. La base del tejido social es la familia que se encuentra organizada en comunas. Es un pueblo eminentemente agrícola, artesano y comercial. Mantienen creencias católicas de herencia colonial (culto a Dios, Jesús y los santos) y ritos institucionalizados (carnavales, semana santa, finados, reyes, navidad, bautizos, matrimonios) con ritos ancestrales de relación con la naturaleza como el Inti-Raymi o la Jahuay (fiesta de la cosecha).

El pueblo Cañari se asienta en la sierra sur ecuatoriana, en las provincias de Azuay y Cañar. Los Cañaris son bilingües. Las lenguas principales son el kichwa y el español. Su población constituye el 2,81\% (aproximadamente 150.000 habitantes) de la población indígena de Ecuador que constituye, a su vez, un 7,03\% del total de la población del país (14.483.499 personas). Su estructura organizativa se rige bajo la concepción comunitaria tradicional sustentada en principios de solidaridad y reciprocidad, pero con nuevos mecanismos de cohesión de corte capitalista. La base del tejido social es la familia que se encuentra organizada en aproximadamente 387 comunidades, siendo la máxima autoridad de todas las comunidades la Asamblea Comunitaria. Mantienen creencias católicas de herencia colonial (culto a Dios, Jesús y los santos) y ritos institucionalizados (carnavales, semana santa, finados, reyes, navidad, bautizos, matrimonios) con creencias ancestrales basadas en leyendas (la leyenda de guacamayas, la leyenda de culebritas, la leyenda de los cajones, la leyenda del jinete) con ritos ancestrales de relación con la naturaleza como el Inti-Raymi (INEC 2010).

Estas relaciones identitarias no son entendidas en una relación de equilibrio u homogeneidad, sino que son pensadas en continua conflictualidad entre las distintas adscripciones de las propias personas (por ejemplo: indígena, mujer, campesina) y en relación a la situación en la que se lleve a cabo la interacción. (Rivera Cusicanqui 2010).
} 
(mujeres especialmente y a España en particular por la incorporación de las mujeres españolas al mercado laboral y la delegación del espacio doméstico y los cuidados a mujeres del sur global (Pérez-Orozco 2006; Pérez Gañán y Neira 2017)). No obstante, esta migración respondía también a un intercambio de información a través de las redes conformadas que percibían una mayor posibilidad de cubrir ciertos nichos laborales (servicio doméstico y cuidados) atribuidos tradicionalmente a las mujeres (Herrera y Martínez 2002: 9). A pesar de la actual crisis a nivel mundial y concretamente de los espacios geográficos de destino de la migración ecuatoriana como España e Italia, la migración exterior se mantiene (con descensos marcados), aunque cambian, sin embargo, las estrategias, los plazos, los ámbitos de inserción laboral y los destinos (Herrera, Moncayo y Escobar 2012).

Por su parte, las y los cañaris, son actores de la práctica migratoria los últimos veinte años en un intento de garantizar la seguridad económica de sus familias (Hirschkind 1995). Según datos del Instituto Ecuatoriano de Estadística (INEC) el $41 \%$ de los hogares del cantón Cañar posee uno o más miembros del núcleo familiar que han migrado a un país extranjero (Herrera, Moncayo y Escobar 2012). Gioconda Herrera y Alexandra Martínez señalan que la migración del Cañar (y del Azuay) ha sido estudiada "como resultado tanto de la política macroeconómica como de lo que se ha empezado a llamar "el síndrome migratorio"" (Herrera y Martínez 2002: 7). Un "síndrome migratorio" que, siguiendo las líneas de trabajo de Walmsley, está conformado no solo por las necesidades de supervivencia, sino por el impacto cultural (cambios en las creencias y en las prácticas) que se genera (Walmsley 2001). Asimismo, Kyle señala como la migración cañar durante los años ochenta no es un fenómeno aislado sino que es un proceso consecuencia de una tendencia y, especialmente, de unas redes transnacionales establecidas por las y los primeros migrantes y que han posibilitado "el camino a miles de personas" (Kyle 2000). Redes migratorias que, según Gurak y Caces (1998), tendrán unas funciones que condicionarán los procesos migratorios como: [...] amortiguar el peso que tienen sobre los migrantes lo costos y la ruptura vital que supone la migración; aislar a los migrantes de la sociedad de destino, (es decir, prolongar y a veces evitar su proceso de adaptación) y mantener sus vínculos con la sociedad de origen" (Citado en Pedone 2001: 7). Asimismo, continua la autora, van a "determinar hasta cierto punto quiénes son los que emigran de las comunidades y las familias; influir en la selección de lugares de destino y de origen; condicionar la integración de los migrantes en la sociedad de destino, servir como canal de información y otros ítems" (Ibídem). 
$\mathrm{Al}$ igual que las redes migratorias se erigen como estrategias para comenzar el viaje, la identidad va a conformarse como una estrategia(s) a la hora de posicionarse en los nuevos espacios en el país de destino. Aquí, la adscripción de clase, religión, adscripción política, ciudadanía, equipo de fútbol o, especialmente etnia -el sujeto de estudio que nos ocupa-, van a activarse en las interacciones cotidianas ${ }^{3}$ definiendo representaciones, narrativas y prácticas que van a incidir en la inserción de las personas migrantes.

\section{METODOLOGÍA}

La metodología utilizada para aproximarse al análisis de la afiliación, la representaciones sociales y las prácticas religiosas de las y los migrantes saraguros y cañaris en España responde a un enfoque cualitativo cuya técnica principal ha sido el análisis crítico del discurso (ACD) de la información obtenida (Van Dijk 1990, 2003), por un lado, a través de la entrevista semiestructurada y, por otro, del grupo focal (Valles 2002; Cannell y Kahn 1993). Concretamente se han realizado quince entrevistas a migrantes indígenas retornados en la localidad de Saraguro, Ecuador, cinco entrevistas a migrantes indígenas cañaris en la ciudad de Cañar, Ecuador, cinco entrevistas a migrantes indígenas cañaris y cinco entrevistas a migrantes indígenas saraguros en Madrid y Valencia, España. Además de las entrevistas se llevó a cabo un grupo focal con diez integrantes en el municipio de Parla en Madrid, España, con personas cañaris y mestizas. Las entrevistas responden a un muestreo no probabilístico por bola de nieve con la intencionalidad de identificar a los sujetos potenciales para la investigación ${ }^{4}$, debido a la dificultad de encontrar individuos por otros medios como listados o registros ${ }^{5}$.

\footnotetext{
${ }^{3}$ Se trató de mantener un equilibrio entre hombres y mujeres, no obstante, de las veinte entrevistas realizadas a migrantes retornados en Ecuador, doce corresponden a mujeres y ocho a hombres. De las diez entrevistas realizadas en España, seis corresponden a mujeres y cuatro a hombres. El grupo focal estaba compuesto por seis mujeres y cuatro hombres.

${ }^{4}$ El trabajo de campo se realizó en un contexto de crisis en España con un cada vez mayor número de retornos de ecuatorianos/as a su país de origen. El acercamiento al objeto de estudio (migración, etnicidad, religión) fue complejo por la sensibilidad que estos temas suscitan.

Como ejemplo podemos citar la publicidad que reparten las iglesias evangélicas en las que, además de los horarios de culto y de reunión se ofrecen servicios gratuitos de asesoramiento médico, psicológico, legal o laboral.

Los rumores y sus circularidades entre España y Ecuador, especialmente con los medios tecnológicos actuales, son muy prolíficas, ejerciendo, en la distancia como mecanismos de control social.

${ }^{5}$ Este proceso de secularización se refleja en el último barómetro realizado por el Centro de Investigaciones Sociológicas (CIS) en España publicados en octubre de 2014 donde un $67,8 \%$ de la población española se considera católica, sin embargo, menos de un $61,0 \%$ de quienes se autodefinen como creyentes de alguna religión señala no asistir a misa o a otros
} 
Asimismo, se realizó un trabajo complementario de observación en campo (Wodak 2002; Guber 2001) en varios espacios de asociación y de culto a los que acudían las personas migrantes indígenas ecuatorianas en las provincias de Valencia y Madrid y en varios lugares en Azogues y Saraguro, en Ecuador. El tipo de observación realizado responde a una observación no participante conformada a partir de cuatro dimensiones de análisis: a) una delimitación espacial adscrita a cuatro espacios principales: el departamento de servicios sociales del Ayuntamiento de Parla en Madrid, la sede de la organización Intiñam en Valencia, el mercado central en Azogues y la plaza de mercado central en Saraguro. Adicionalmente se realizaron observaciones esporádicas en las Parroquia de los Santos Justo y Pastor y Nuestra Señora de la Paz en Parla, la Catedral de Valencia, la Catedral de Azogues y la Iglesia Matriz de Saraguro; b) una delimitación temporal llevada a cabo durante siete meses (de diciembre de 2013 marzo de 2014 en España y de abril a junio de 2014 en Ecuador) en la que se realizaron observaciones con una frecuencia semanal en España y una vez cada tres semanas en Ecuador; c) una delimitación de los roles de las y los migrantes en los espacios frecuentados, en relación, fundamentalmente, con los prácticas laborales; y d) una delimitación de las prácticas religiosas habituales a través del análisis de los comportamientos y prácticas religiosas. Las cuatro dimensiones propuestas se presentan estrechamente relacionadas entre sí y se configuran como parte indispensable del todo que conforma la observación.

Se ha utilizado el programa Atlas.ti 7 como herramienta para el análisis asistido por ordenador en la organización y manejo de los datos de las entrevistas y de los registros de campo.

\section{RESULTADOS DE INVESTIGACIÓN}

4.1. La influencia de la ayuda social de "cáritas" y la "necesidad de trabajar" como variables de anclaje a la afiliación católica y de transformación en las representaciones sociales y prácticas religiosas de los pueblos saraguro y cañar en España

Yo soy de la religión católica. Allá igual, religión católica [...] iba a misa los domingos porque mi mamá trabajaba de lunes a sábado y solo teníamos los domingos para ir a la misa y a las canchas.

(Elisabeth, indígena cañari retornada, 22 años)

oficios religiosos casi nunca. A un 30,8\% de la población encuestada la religión le parece algo "nada importante" y un 87,6\% nunca ha sido parte de una organización religiosa (CIS 2014). 
En relación al objeto de estudio propuesto -la existencia de cambio religioso en las poblaciones saraguro y cañari de Ecuador en su migración a España-, y en línea con el marco referencial planteado, en especial con los conceptos de afiliación religiosa (Durkheim 2008 [1912]) y "objetivación y anclaje" señalados por Moscovici (1989) en relación a las representaciones sociales y prácticas religiosas, "la configuración y composición del mapa religioso de la sociedad de llegada es una variable muy relevante para comprender de qué manera las comunidades de inmigrantes contextualizan y adaptan la vivencia y la práctica religiosa en el entorno de la sociedad receptora" (Martínez-Ariño et al. 2011: 107). Cuando se produce la migración de países de Latinoamérica hacia España, estos tres factores (diferencia lingüística, diferencia religiosa dominante y ausencia de préstamos culturales) se atenúan y se ponen, por el contrario, otras estrategias diferentes en juego, como pueden ser el asociacionismo (indígena en este caso) y la participación en organizaciones religiosas católicas -que posibilitan una continuidad de creencias y prácticas realizadas en origen en el país de destino- y que van a conducir esta afiliación y prácticas religiosas más que hacia un cambio de creencias, hacia una redefinición de la afiliación y de las prácticas (Warner y Wittner 1998; Ebaugh y Chaftez 2000; Menjívar 2003; Furseth y Repstad 2006).

Aunque la coexistencia de una situación de vulnerabilidad en relación a "la exposición a un contexto de mayor diversidad" y el "distanciamiento de los mecanismos de control" (Odgers 2006: 402) que experimentan las personas migrantes a su llegada al país de destino, puede facilitar a priori, un cambio en las afiliación y en las prácticas religiosas como consecuencia de un control social más distendido y de organizaciones religiosas que captan adeptos a través de promociones de ayuda en la inserción ${ }^{6}$, las realidades que se encuentran las personas migrantes al llegar a España son ligeramente diferentes. En primer lugar, al compartir el idioma y algunas raíces culturales -religión católica, entre otras-, aunque existe un "choque" de culturas, no se erige como un obstáculo insalvable. Los discursos de las personas entrevistadas señalaban como son las mujeres las que interaccionan mayoritariamente con los espacios de reproducción social, teniendo los hombres que "trabajar más y poder ocuparse de esas cosas". De ese modo, las mujeres se erigen como protagonistas de, en este caso, del acercamiento a las organizaciones sociales e instituciones religiosas y la

\footnotetext{
${ }^{6}$ Según la investigación de Pérez-Agote y Santiago "La nueva pluralidad religiosa" (2009) publicada por el Ministerio de Justicia de España, un 42\% de las personas migrantes declaraban ser evangélicas. Sin embargo, esta información no se refleja en la población entrevistada en este trabajo, ya que excepto uno de los entrevistados, el resto seguía considerándose católico/a.
} 
reproducción social (anclaje) que se origina de estas interacciones: "Sí es duro al llegar mija, es otra cosa [...], pero, igual una se "enseña" a vivir, a trabajar... y, pues, hablamos casi igualito y eso ayuda, mija" (María Purificación, indígena saraguro retornada, 52 años). De igual modo, la multitud de redes previas existentes organizadas -como se señalaba en el caso de Inti-Ñan- o no organizadas -familiares y amigos/as-, que participan de la afiliación y prácticas religiosas católicas hacen a la vez de elemento facilitador de la inserción (anclaje) y de control social en destino ${ }^{7}$ (objetivación) lo que limita el contacto con "lo otro" (Moscovici 1989; Furseth y Repstad 2006), en este caso, con otras religiones: "A nosotros nos gusta la organización, por ejemplo, hemos estado bien organizados, entre nosotros, toda la gente [...] Inti-Ñan que se llamaba en España, de todos los indígenas. Se iban de Murcia, de Almería, de Valencia... entonces nos organizamos este grupo de personas" (María Juana, indígena cañari retornada, 47 años, Cañar, 2014).

En relación con las organizaciones religiosas (no católicas) que tratan de atraer a estas personas migrantes por su condición de vulnerabilidad hacia sus congregaciones, puede observarse que en España aún no tienen la fuerza y el arraigo suficiente -aunque esta fuerza va creciendo notablemente ante la "crisis de religiosidad" (Pérez-Agote 2012) que vive el país en los últimos añospara competir con las organizaciones religiosas católicas que operan en estos territorios. Multitud de testimonios recogidos en las entrevistas citan a la organización católica Cáritas como la entidad que les prestó ayuda en el momento en el que llegaron al país, organización que a pesar de no ejercer un rol propiamente de entidad religioso sino de asistencia social -como se ha señalado con anterioridad-, está muy relacionada con la iglesia católica, entre otras cosas, por el conocimiento previo de su trabajo en Ecuador -donde sí tiene un carácter más religioso-. Esta organización -a la que según las narrativas de las y los entrevistados acuden principalmente las mujeres-, sirve de anclaje en destino permitiendo una continuidad de afiliación representaciones sociales y prácticas en el lugar de destino.

Yo tuve ayuda sí, desde que llegué, Cáritas me ayudó con la ropa para mi hijito, podías comer, tenían buenos comedores donde podías comer [...] conmigo se portaron muy bien, me ayudaron mucho, ahí conocí a mucha gente buena en España... hay racismo y muchas personas son racistas y es duro, muy duro

${ }^{7}$ Los rumores y sus circularidades entre España y Ecuador, especialmente con los medios tecnológicos actuales, son muy prolíficas, ejerciendo, en la distancia como mecanismos de control social. 
cuando llegas y con un bebé... pero hay mucha gente buena también... Cáritas me "salvo la vida" [risas]. (Aracely, migrante ecuatoriana mestiza, 29 años, Parla, 2014).

A pesar de que se han registrado casos de cambio en los sistemas de creencias y de afiliación religiosa en las migraciones hacia España y una circularidad y comunicación de estos cambios con las familias y sociedades en origen donde la experiencia migratoria: "[...] configura también un contexto favorable al cambio religioso [...] debido a que los sistemas de creencias son fuertemente movilizados y reinterpretados en la búsqueda de nuevos sentidos para la existencia propia, para la representación del origen, y para la construcción de esperanzas para el porvenir (Odgers 2006: 411). Sin embargo, es necesario señalar que este cambio hacia otra religión no ha sido la situación observada durante la investigación sino que más bien se han encontrado cambios en las representaciones y prácticas religiosas dentro de la afiliación católica (distanciamiento por excesivo trabajo, formas distintas de vivir la religiosidad, transformación de las prácticas del día a día, sincretismo con algunos ritos indígenas, etc.).

Yo siempre he sido católico, y lo he seguido manteniendo, ¿no? Allá, pero no con mucho... como le diría... no ha sido constante ir a la iglesia... me he ido muy poco porque... se supone que los españoles nos trajeron la religión, pero allí al menos se ve que los jóvenes ya no se van a misa... hacen la comunión y de ahí ya no pasan... se olvidan... y ahí yo me doy cuenta, ¿no?, de qué tipo de religión nos han inculcado... y ahí como que te nace un poco de desconfianza [...] yo encontré que era otra la visión que tenían aquí, la visión comunitaria era otra, los festejos religiosos eran otros... estamos recuperando lo que nosotros teníamos, lo que habíamos perdido ¿no? Las creencias en la Madre Tierra, en la Naturaleza. (Miguel, indígena saraguro retornado, 46 años)

En este sentido, siguiendo a Stepick (2006), la pertenencia, identificación, discurso y práctica religiosa se resignifican en los contextos migratorios y se refuerzan los vínculos religiosos en las trayectorias personales dentro de la experiencia migratoria. Siguiendo esta línea, la mayor parte de las personas indígenas entrevistadas se referían a la migración como un proceso que había influenciado sobre ellos y ellas y les había hecho repensar aspectos de su identidad, de sus sistemas de creencias (sin cambiarlos) y de sus prácticas:

Ahora tengo una fe en mí misma, en las personas, en lo humano, en la práctica... antes íbamos a misa, mi mamá nos obligaba a ir todas las mañanas a misa, y yo digo obligado porque iba con pereza, no era tan... así. Ahora voy a misa, pero cuando yo siento, cuando yo quiero, voy con gusto, voy porque siento la necesidad o el gusto de ir a la iglesia [...] ahora tengo una fe más "lógica". (Alexandra, indígena saraguro retornada, 32 años) 
No obstante, un factor recurrente en los diferentes testimonios, era que, a pesar de mantener la afiliación católica se producía un distanciamiento de las prácticas como consecuencia del excesivo trabajo que realizaban en sus lugares de destino en España y que les impedía acudir con asiduidad a los ritos cotidianos: "Eso era solo los domingos... porque nosotros hacíamos por no perder esas costumbres, tener fe en "Diosito" [...] pero ya no tocaba ir todo los domingos a misa, por trabajo, solo cuando no hay que trabajar íbamos a la iglesia" (Tránsito, indígena cañari retornada, 45 años).

Siguiendo los postulados de Pérez-Agote (2012) encontramos que las organizaciones religiosas -en su enfoque de ayuda social-, y los espacios que simbolizan se erigen como un factor de integración (anclaje) de las y los migrantes en la sociedad de destino, ya que se convierten en lugares donde las personas acuden para tratar sus problemas cotidianos, compartir experiencias con personas en su misma situación, solicitar y dar consejo y donde pueden crear un sentido de pertenencia y adquirir un "estatuto de normalidad" (PérezAgote 2012).

Yo, en el primer sitio en el que me refugié, o encontré ayuda, yo creo que también la mayoría, no sé, fue en Cáritas, donde llegabas, te apuntabas ahí, y, en principio, ya te daban alimento, te asesoraban de pronto dónde ir para legalizar tu situación, o incluso te ayudaban... en esa época había trabajo [...] y había muchas otras que llegaban de Ecuador con sus hijitos y hablábamos mucho... y hasta amistad hacías... y encontrabas hasta parientes. (Marta, migrante ecuatoriana kichwa, Parla, 2014)

Por otro lado, un fenómeno que llama la atención es la importancia que esta migración está teniendo en el mantenimiento de los ritos católicos en una España inmersa en un fuerte proceso de secularización ${ }^{8}$ (Pérez-Agote 2012) en los últimos años. Durante el trabajo de campo se observaron varios espacios religiosos católicos y evangélicos en España (Valencia y Madrid) y pudo constatarse la gran afluencia en los ritos religiosos de migrantes latinoamericanos, una participación más elevada, muchas veces, que la de los propios españoles y españolas (especialmente las y los jóvenes).

${ }^{8}$ Este proceso de secularización se refleja en el último barómetro realizado por el Centro de Investigaciones Sociológicas (CIS) en España publicados en octubre de 2014 donde un $67,8 \%$ de la población española se considera católica, sin embargo, menos de un $61,0 \%$ de quienes se autodefinen como creyentes de alguna religión señala no asistir a misa o a otros oficios religiosos casi nunca. A un 30,8\% de la población encuestada la religión le parece algo "nada importante" y un $87,6 \%$ nunca ha sido parte de una organización religiosa (CIS 2014). 
La mayor parte de mis feligreses... bueno, ahora sí vienen muchos América... españoles también hay claro [...] si no fuera por ellos, sería muy difícil... muy pocos vienen, solo a bodas, bautizos... en Navidad. (Esteban, párroco valenciano, 52 años)

Por ello, es necesario señalar el destacado papel que las comunidades inmigrantes tienen a la hora de alterar, cambiar y reconfigurar "el paisaje religioso en las sociedades receptoras" (Stepick 2006: 13) alejándose de concepciones en las que se le atribuye un rol lineal a la religión en los contextos migratorios "como si se tratara de un proceso de «trasplantación» de las comunidades religiosas de origen en la diáspora" (Cit. en Martínez-Ariño, et al. 2011: 106). En este estudio, la mayor parte de las personas entrevistadas narraban sus visitas a otras comunidades religiosas fuera de la católica tanto en España como en Ecuador, con un interés "en conocer" y "en qué tenían que ofrecer" estos espacios. De igual manera, señalaban tener varias personas a su alrededor que ya pertenecían a otras iglesias, especialmente a la iglesia evangélica, que no les era del todo ajena. Sin embargo, estas personas tanto en el país de destino como en el retorno habían permanecido con afiliación a la religión católica. Así desde el mantenimiento de su afiliación religiosa, las (re)construcciones y (re)apropiaciones de las representaciones y prácticas religiosas "[...] dan forma a la experiencia migratoria transnacional al mismo tiempo que la población migrante modifica y recrea las religiones globales convirtiéndolas en locales y empezando el proceso de nuevo" (Levitt, 2003: 848).

Yo muchas de las veces he estado en muchas iglesias, o sea, no solo en lo que son católicas, he estado también en iglesias de mormones, ultimadamente pues hay evangélicos, hay protestantes [...] yo lo veo aquí mismo, en lo que es Ecuador. Se ha dividido la iglesia, yo no sé qué pasó... uno empieza a ver muchas creencias, muchas sectas... y he acudido a todas esas... me ha gustado, o sea, en España ayudar a la gente cuando he podido. (Manuel, indígena cañari retornado, 40 años)

Finalmente, es necesario señalar que el impacto que la migración latinoamericana $-y$, en este caso concreto, migración de personas indígenas del austro ecuatoriano- está teniendo sobre el mapa religioso español implica atribuir a esta migración un papel importante en la continuidad de una afiliación y prácticas católicas fuertemente amenazadas por el auge tanto de un laicismo como de otro tipo de religiones, especialmente la evangélica ${ }^{9}$. Sin estos flujos

9 Según la investigación de Pérez-Agote y Santiago "La nueva pluralidad religiosa" (2009) publicada por el Ministerio de Justicia de España, un 42\% de las personas migrantes declaraban ser evangélicas. Sin embargo, esta información no se refleja en la población 
migratorios, es posible que la situación de la afiliación religiosa en el país tuviera una balanza mucho más reducida.

\section{CONSIDERACIONES FINALES}

En la migración de las poblaciones indígenas estudiadas del austro ecuatoriano hacia el levante y centro español más que producirse un cambio de afiliación religiosa - como sucede con frecuencia en contextos migratorios a otros países como Estados Unidos-, se configura una transformación heterogénea en las representaciones y prácticas hacia el interior de la propia religión católica. En este sentido, la confluencia de la religión católica entre el país de origen (Ecuador) y el de destino (España) junto a un apoyo socio-económico de la organización Cáritas (en España) van a servir de anclaje y continuidad de afiliación, representaciones y prácticas religiosas. No obstante, bajo la premisa "hay que trabajar", tan citada por las voces recogidas en este trabajo, aunque los sistemas de creencia y la afiliación no cambien, las representaciones y prácticas se flexibilizan y ajustan para integrarse en el país de destino. Esta integración se enfoca, principalmente, en tratar de trabajar mucho y ganar dinero para invertirlo en diferentes propósitos (envío de remesas, ahorros para el retorno, estudios, etc.). Las largas jornadas de trabajo (de más de diez horas en varios de los sujetos entrevistados) dificultan las prácticas religiosas comunitarias favoreciendo prácticas más privadas. En la privacidad, la religiosidad es repensada y adaptada a la nueva cotidianidad. Esta migración indígena ecuatoriana y la religiosidad que la acompaña se articula además -y dentro de un contexto más amplio de migración latinoamericana-, como un factor relevante a la hora de definir el mapa religioso actual y futuro de España, un país inmerso en un profundo proceso de secularización y diversificación religiosa.

Estas largas jornadas van a afectar a otras prácticas culturales, más allá de las religiosas, siendo las mujeres las que tienden a ocupar más horas al día con trabajo, estudios y asociacionismo bajo las narrativas de "aprovechar el tiempo" y "aprovechar las oportunidades". Aquí, los roles y las relaciones de género, aunque siguen ocupando los espacios tradicionales, también se flexibilizan, teniendo que organizarse los hogares de forma distinta. Paralelamente, el asociacionismo como elemento de supervivencia y de apoyo mutuo es una idea presente en los discursos de las personas entrevistadas, quienes señalan continuamente la importancia del mismo para afrontar sus realidades como migrantes indígenas y las problemáticas que de estas identidades se derivan.

entrevistada en este trabajo, ya que excepto uno de los entrevistados, el resto seguía considerándose católico/a. 
En el contexto de crisis en el que se realizó este estudio, el retorno era una opción habitual de la población analizada, a la que la dicha crisis había afectado profundamente. Gran parte de las personas entrevistadas en Ecuador habían retornado en los últimos dos años y habían abierto pequeños negocios en sus ciudades de origen. Aquí, los hábitos de trabajo adquiridos en España y las prácticas religiosas (re)apropiadas eran desplegadas por estos y estas migrantes, que se enfrentan ahora, a unas nuevas problemáticas que surgen del contraste cultural entre sus nuevas formas de trabajo y religiosidad y su integración en "nuevos" contextos.

\section{REFERENCIAS}

Ariza, M. (2007). "Itinerario de los estudios de género y migración en México". En M. Ariza y A. Portes (Eds.), El país transnacional: migración mexicana y cambio social a través de la frontera. México D.F.: Universidad Autónoma de México, 453-491.

Bacacela, S. (2003). "La migración en los Saraguros: Aspectos positivos y negativos". Boletín ICCI-ARY Rimay [publicación mensual del Instituto Científico de Culturas Indígenas], 5(48), 1-5.

Barth, F. (1976). "Introducción". En F. Barth (Ed.), Los grupos étnicos y sus fronteras. México D.F: Fondo de cultura económica.

Bastian, J. P. (1997). La mutación religiosa en América Latina. Para una sociología del cambio religioso en la modernidad periférica. México D.F: Fondo de Cultura Económica.

Belote, J. (1998[1984]). Los Saraguros del Sur del Ecuador. Quito: Abya-Yala.

Belote, J. y Belote, L. (1985). "Vertical Circulation in Southern Ecuador". En M. Prothero y M. Chapman (Eds.), Circulation in Third World Countries. London: Routledge \& Kegan Paul, 160-177.

Butler, J. (2002 [1993]). Cuerpos que importan. Sobre los limites materiales y discursivos del 'sexo'. Buenos Aires: Paidós.

Cannell, C. y Kahn, R. (1993). "La reunión de datos mediante entrevistas". En L. Festinger y D. Katz (Comps.), Los métodos de investigación en las ciencias sociales. Barcelona: Paidós, 310-352.

Cáritas (2017). "Presupuesto 2017". [En línea], s/p, disponible en: http://www.cari tas.es/cCaritas_financiacion.aspx (consultado el 10/10/2018)

Castells, M. (1998). La Era de la Información. Economía Sociedad y Cultura: la sociedad red (Vol.1). Madrid: Alianza Editorial.

CIS (2014). Barómetro octubre de 2014. [En línea], disponible en: http://www.cis.es/cis/ opencm/ES/1_encuestas/estudios/ver.jsp?estudio=14119 (consultado el 14/10/2018)

Cruz Zúñiga, P. (2014). "La migración de pueblos indígenas de Bolivia y Ecuador en España". Amérique Latine Histoire et Mémoire. Les Cahiers ALHIM. [En línea], s/p, disponible en: http://alhim.revues.org/4974 (consultado el 14/10/2018)

Cruz Zúñiga, P. (2010). "Pueblos indígenas, migración transnacional e identidades. Retos y desafíos en la migración de los pueblos indígenas de Ecuador hacia España". Rev. Inter. Mob. Hum., XVIII(34), 81-98. 
Darvishpour, M. (2003). "Immigrant women challenge the role of men: How the changing power relationship within Iranian families in Sweden intensifies family conflicts after immigration". Journal of Comparative Family Studies, 33(2), 271-296.

De la Torre, R. y Gutiérrez C. (Coords.) (2007). Atlas de la diversidad religiosa en México (1950-2000). México: El Colegio de Jalisco, El Colegio de la Frontera Norte, CIESAS, El Colegio de Michoacán, Secretaría de Gobernación y Universidad de Quintana Roo.

Durand, J. y Massey, D. (2001). Milagros en la frontera. Retablos de migrantes mexicanos a Estados Unidos. México: El Colegio de San Luis, Centro de Investigaciones y Estudios Superiores en Antropología Social.

Durkheim, E. (2008 [1912]). Las formas elementales de la vida religiosa. Madrid: Akal.

Ebaugh H. y Chafetz, J. (2000). Religion and the new immigrants: Continuities and adaptations in immigrant congregations. Walnut Creek: Altamira Press.

Espinosa, V. (1999). "El día del emigrante y el retorno del purgatorio: Iglesia, migración a los Estados Unidos y cambio sociocultural en un pueblo de Los Altos de Jalisco". Estudios Sociológicos, XVII(50), 375-418.

Esteban-Guitart, M., Vila, I. y Bastiani J. (2010). "El carácter fronterizo de las identidades contemporáneas. El caso de Chiapas". Aposta Revista de Ciencias Sociales, 44, 1-19, disponible en: http://www.apostadigital.com/revistav3/hemeroteca/ m0ises2.pdf (consultado el 10/10/2018).

Fréderiks, M. y Nagy, D. (2016). Religion, Migration and Identity: Methodological and Theological explorations. Leiden: Brill.

Furseth, I. y Repstad, P. (2006). An introduction to the sociology of religion: classical and contemporary perspectives. Aldershot: Ashgate Pub Co.

Galaviz, G., Odgers Ortiz, O. y Hernández, A. (2009). "Tendencias del cambio religioso en la frontera norte de México". En C. Rivera y A. Hernández (Eds.), Regiones y religiones en México. Estudios de la transformación sociorreligiosa. Tijuana: El Colef/ Ciesas/Colmich, 227-239.

García, P. (2008). "El carácter transnacional de las creencias y prácticas religiosas de los inmigrantes latinoamericanos en España”. Comunicación presentada en el I Congreso "Nuevos retos del Transnacionalismo en el estudio de las migraciones", 14 y 15 de febrero. Barcelona: Universidad Autónoma de Barcelona, disponible en https://docsgedime.files.wordpress.com/2008/02/tc-paola-garcia.pdf (consultado el 14/10/2018)

García Canclini, N. (1999). "La globalización: objeto cultural no identificado". En N. García Canclini (Comp.). La globalización imaginada. Barcelona: Paidós, 45-65.

Giddens, A. (1995). La Constitución de la Sociedad. Bases para una Teoría de la Estructuración. Buenos Aires: Amorrortu editores.

Gluckman, M. (1987). "Análisis de una situación social en Zululandia moderna”. En B. Feldman Bianco (Comp.), Antropología de las sociedades contemporáneas. São Paulo: Global, 227- 344.

Guber, R. (2001). La Etnografía. Método, campo y reflexividad. Buenos Aires: Siglo XXI Editores. 
Gurak, D. y Caces, F. (1998). "Redes migratorias y la formación de sistemas de migración". En G. Malgesini (Comp.), Cruzando fronteras. Migraciones en el sistema mundial. Barcelona: Icaria- Fundación Hogar del empleado, 75-112.

Hernández, A. (2007). "El cambio religioso en México: crecimiento y auge del pentecostalismo". En C. Rivera Farfán y E. Juárez Cerdi (Eds.), Más allá del espíritu. Actores, acciones y prácticas en iglesias pentecostales. México: CIESAS/El Colegio de Michoacán, 53-90.

Herrera, G. (2005). "Mujeres ecuatorianas en las cadenas globales del cuidado". En G. Herrera, C. Carrillo y A. Torres (Eds.), La migración ecuatoriana. Transnacionalismo, redes e identidades. Quito: FLACSO Ecuador, 281-304.

Herrera, G. y Martínez, A. (2002). Género y migración en la región Sur. Informe de investigación. Quito: FLACSO Ecuador.

Herrera G., Moncayo M. I. y Escobar, A. (2012). Perfil migratorio del Ecuador 2011. Quito: Organización Internacional para las Migraciones (OIM).

Hervieu-Leger, D. (1996). "Por una sociología de las nuevas formas de religiosidad: algunas cuestiones teóricas previas". En G. Giménez (Coord.), Identidades religiosas y sociales en México. México: IFAL/IIS-UNAM, 23-46.

Hirschkind, L. (1995). "History of the Indian Population of Cañar, Colonial Latin". American Historical Review, 4(3), 311-342.

INEC (2010). "Censo Nacional de Población y Vivienda 2010. Ecuador". INEC Ecuador [en línea], disponible en: http://www.ecuadorencifras. gob.ec/censo-de-poblaciony-vivienda/ (consultado el 17/09/2017).

Kurtz, L. (1995). Gods in the Global Village. The World's Religions in Sociological Perspective. Thousand Oaks: Pine Forge Press.

Kyle, D. (2000). Transnational Peasants, Migrations, Networks and Ethnicity in Andean Ecuador. Baltimore: John Hopkins University Press.

Leach, E. R. (1954). Political Systems of Highland Burma. London: Bell.

Levitt, P. (2003). "You Know, Abraham was really the First Immigrant: religion and transnational Migration". International Migration Review, 37(3), 847-873.

Levitt, P. y Jaworsky, N. (2007). "Transnational Migration Studies: past developments and future trends". Annual Review of Sociology, 33, 129-156.

López, D. y Oso, L. (2007). "La inmigración latinoamericana en España. Tendencias y estado de la cuestión". En I. Yépez y G. Herrera (Eds.), Nuevas migraciones latinoamericanas a Europa. Balance y desafíos. Quito: FLACSO-OBREAL-UCL-UB, 31-67.

Mallimaci, A. (2016). "Prácticas religiosas en contextos de migración. Algunas articulaciones entre transnacionalidad, localidad e identidades". Papeles del CEIC. International Journal on Collective Identity Research, 1. [En linea], disponible en: http://www.redalyc.org/articulo.oa?id=76544802010 (consultado el 14/10/2018).

Martínez-Ariño, J. et al. (2011). "Inmigración, diversidad religiosa y centros de culto en la ciudad de Barcelona”. Migraciones, 30, 101-133.

Massey, D. (2004). "Lugar, identidad y geografías de la responsabilidad en un mundo en proceso de globalización”. Treballs de la Societat Catalana de Geografia, 57, 77-84. 
Maussen, M. (2004). "Policy discourses on mosques in the Netherlands 1980-2002: contested constructions". Ethical Theory and Moral Practice, 7(2), 147.

Menjívar, C. (2003). "Religion and immigration in comparative perspective: Catholic and Evangelical Salvadorans in San Francisco, Washington, DC, and Phoenix". Sociology of Religion, 64(1), 21-45.

Morcillo, J. M. (2012). "Una breve revisión de las teorías de las migraciones desde una perspectiva de género. Mujeres rompiendo estereotipos. IV Congreso Virtual sobre historia de las mujeres. [En línea], s/p, disponible en: https://dialnet.unirioja.es/ servlet/articulo? codigo=4714900 (consultado el 13/10/2018).

Moscovici, S. (1989). "Des représentations collectives aux representations sociales: elements pour une histoire". En D. Jodelet (Ed.). Les Répresentations Sociales. París: PUF, 62-86.

Moscovici, S. (1963). "Attitudes and opinions", Annual Review of Psychology, 14, 231-260.

Navarro, O. (2002). "Representaciones sociales de la cultura adaptativa en un pueblo indígena de la Sierra Nevada de Santa Marta (Colombia)". Investigación y Desarrollo, 10(2), 208-221.

O' Connor, M. (2001). "Evangelicals in the Lower Mayo Valley". En A. R. Sandstrom y J.W. Dow (Eds.), In Holy Saints and Fiery Preachers: The Anthropology of Protestantism in Mexico and Central America. New York: Praeger, 25-56.

Odgers Ortiz, O. (2014). "Migración y cambio religioso en México: perspectivas de análisis y agenda de investigación”. Cultura y religión, 8(1), 151-167.

Odgers Ortiz, O. (2006). "Cambio religioso en la frontera norte. Aportes al estudio de la migración y las relaciones trangronterizas como factores de cambio". Frontera Norte 18(35),111-134.

Pedone, C. (2002). "El potencial del análisis de las cadenas y redes migratorias en las migraciones internacionales contemporáneas". En F. G. García Castaño y C. Muriel Lopez (Eds.), Actas del III Congreso sobre la inmigración en España. Contextos y alternativas. Granada: Laboratorio de Estudios Interculturales, 223-235.

Pérez-Agote, A. (2016). "La religión como identidad colectiva: las relaciones sociológicas entre religión e identidad". Papeles del CEIC. International Journal on Collective Identity Research, 2, 1-29.

Pérez-Agote, A. (2012). Cambio religioso en España: Los avatares de la secularización. Madrid: Centro de Investigaciones Sociológicas.

Pérez-Agote, A. y Santiago, J. (2009). La nueva pluralidad religiosa. Madrid: Ministerio de Justicia de España.

Pérez Gañán, R. y Neira, A. (2017). "Las abuelas de la migración. Cuidados, reciprocidad y relaciones de poder en la familia transnacional". Migraciones, 41, 55-77.

Pérez Orozco, A. (2006). Laboratorio Feminista. Transformaciones del trabajo desde una perspectiva feminista: producción, reproducción, deseo y consumo. Madrid: Tierra de Nadie.

Rivera Cusicanqui, S. (2010). Ch'ixinakax utxiwa. Una reflexión sobre prácticas y discursos descolonizadores. Buenos Aires: Tinta Limón. 
Rivera Sánchez, L., Odger Ortiz, O. y Hernández Hernández, A. (2017). Mudar de credo en contextos de movilidad. Las interconexiones entre la migración y el cambio religioso. México D.F.: El Colegio de México, El Colegio de la Frontera Norte.

Romizi, F. (2014). El Dios en la maleta. Los caminos de la significación mítica de la realidad de los ecuatorianos católicos en Barcelona y New York. Tarragona: Publicaciones URV/FLACSO Ecuador.

Saint-Blancat, C. (2002). "Islam in diaspora: between reterritorialization and extraterritoriality". International Journal of Urban and Regional Research, 26, 138-151.

Sánchez, D. y Cruz Zúñiga, P. (Eds.). Pueblos indígenas, identidades y derechos en contextos migratorios. Barcelona: Icaria Editorial.

Sayad, A. (1999). La double Absence. Des illusions de l'émigré aux souffrances de l'immigré. Paris: Seuil.

Soper, C. y Fetzer, J. (2007). "Religious institutions, Church-State history and muslim mobilisation in Britain, France and Germany". Journal of Ethnic and Migration Studies, 33(6): 933-944.

Stewart, N., Belote, J. y Belote, L. (1976). "Transhumance in the Central Andes". Annals of the Association of American Geographers, 66(3), 377-397.

Stepick, A. (2006). "God Is Apparently Not Dead: the obvious, the emergent, and the still unknown in immigration and Religion". En K. Leonard et al. (Eds.), Immigrant faiths: transforming religious life in America. Oxford: Altamira Press, 11-38.

Tapia, M. (2011). "Género y migración: trayectorias investigativas en Iberoamérica". Revista Encrucijada Americana, 4(2), 115-147.

Torres, C. (2004). "Globalization, Education and Transformative Social Justice Learning”. En K. Mündel y D. Schugurensky (Eds.). Lifelong Citizenship Learning, Participatory Democracy and Social Change, Vol. 2. Toronto: OISE-Universidad de Toronto, 562-570.

Tual, A. (1979). "Apuntes sobre dos migraciones de los saraguros". Revista de Antropología, 6, 117-129.

Valles, M. (2002). Entrevistas cualitativas. Cuadernos metodológicos 32. Madrid: CSIC.

Van Dijk, T. (2003). Ideología y discurso. Barcelona: Ariel.

Van Dijk, T. (1990). La noticia como discurso: Comprensión, estructura y producción de la información. Barcelona: Paidós.

Walmsley, E. (2001). "Transformando los pueblos: la migración internacional y el impacto social a nivel comunitario". Ecuador Debate, 54, 155- 174.

Warner, S. y Wittner, J. (Eds.) (1998). Gatherings in Diaspora. Religious Communities and the New Immigration. Filadelfia: Temple University Press.

Wodak R. (2002). Methods of Critical Discourse Analysis. Londres: SAGE.

Yeates, N. (2005). "Global Care Chains: a Critical Introduction". Global Migration Perspectives, 44, 1-19, disponible en: http://www.iom.int/jahia/webdav/site/ myjahiasite/shared/shared/mainsite/policy_and_research/gcim/gmp/gmp44.pdf (consultado el 14/10/2018) 


\section{BREVE NOTA BIOGRÁFICA}

ROCÍO PÉREZ GAÑAN. Doctorado Internacional en Antropología Social y Cultural. Máster Iberoamericano en Cooperación Internacional y Desarrollo. Máster en Género y Políticas públicas. Investigadora Postdoctoral del CONICET con centro de trabajo en el Centro de Estudios de la Argentina Rural (Universidad Nacional de Quilmes). Investigadora del Euro-Mediterranean University Institute (EMUI). Publicaciones destacadas: Pérez Gañán, Rocío y Gorka Moreno (2018). "La emigración académica España-Ecuador durante el periodo de recesión económica: ¿Una geoestrategia de supervivencia de docentes e investigadores españoles?" Iberoamerican Journal of Development Studies, 7(1): 6-28; Pérez Gañán, Rocío (2018). "El fuego que arde en las calles, también arde en la cocina". Mujeres indígenas y otras formas de hacer política en los espacios rurales del Buen Vivir ecuatoriano y el Vivir Bien boliviano". Revista Arenal. Revista de historia de las mujeres, 25(1): 95-121; "North-South Migrations and the Asymmetric Expulsions of Late Capitalism: Global Inequality, Arbitrage, and New Dynamics of North-South Transnationalism", Migration Studies, 2017, 5 (1): 116-135. Líneas de Investigación: 1) Identidad(es), sistemas políticos y desarrollo en América Latina, 2) Movilidades contemporáneas, globalización y desarrollo, 3) Género, territorio y medioambiente.

ORCID 0000-0002-2199-5962

Recibido: 02-10-2017

Aceptado: 24-10-2018

\section{(c) (P) Licencia Creative Commons Reconocimiento (CC BY 4.0)}




\section{HOMBRES CUIDADORES INFORMALES EN LA CIUDAD DE VALENCIA. UNA EXPERIENCIA DE RECIPROCIDAD ${ }^{1}$ \\ INFORMAL MALE CAREGIVERS IN THE CITY OF VALENCIA. AN EXPERIENCE OF RECIPROCITY}

\section{Juan A. Rodríguez del Pino Departament de Sociologia i Antropologia Social Universitat de València, España juan.rodriguez@uv.es \\ Teresa Samper Mas Departament de Sociologia i Antropologia Social Universitat de València, España m.teresa.samper@uv.es}

\section{Susana Marin Traura}

Departament de Teoría de la Educació Universitat de València, España susana.marin@uv.es
Enric Sigalat Signes

Departament de Sociologia i Antropologia Social Universitat de València, España enrique.sigalat@uv.es

\author{
Ana Elisa Moreno Ruíz \\ Institut de Estudis de la Dona \\ Universitat de València, España \\ elsmoru@gmail.com
}




\section{Resumen}

Este artículo forma parte de un estudio de la Universidad de Valencia donde se analiza la percepción que algunos hombres tienen acerca del cuidado de personas adultas (mayores y/o discapacitadas) que ellos realizan de manera informal en su entorno familiar en la ciudad de Valencia. A través de entrevistas en profundidad, identificamos, la responsabilidad que estos hombres se toman con la persona cuidada a través del establecimiento de procesos de reciprocidad. Dicha reciprocidad destaca como un elemento positivo a extraer de sus vivencias que permite reivindicar el cuidado como un valor positivo y no exclusivo de ningún género.

Palabras clave: Reciprocidad; hombres; cuidado informal; Valencia.

\section{Abstract}

This article is part of a study from the University of Valencia which analyzes the perception that some men have about the care of adults (elderly and / or disabled) that they do informally in their family environment in the city of Valencia. Through in-depth interviews, we identify the responsibility that these men take with the person cared for through the establishment of reciprocity processes. Such reciprocity stands out as a positive element to extract from their experiences that allows to claim care as a positive value and not exclusive of any kind.

Keywords: Reciprocity, men, informal care, Valencia

\section{Extended abstract}

The changes that have been occurring in our society gradually imply that we are currently observing two important social aspects: as they are, first, dependence, in view of the law that protects it (law 39/2006) as well as the progressive increase in the dependent population; And second, the feminization of the role of caregiver, with the consequences of that is derived. Throughout these changes, gradual and unreachable, a greater involvement of men is demanded beyond the "I help you?".

In the city council of Valencia they wanted to know what the situation was and at what point were the men who cared for their dependent people. Therefore, in this study, the need for is justified

a) to observe how the caregivers who exist, their own role as caregivers, live.

b) to determine which elements of value can have for the caregiver the attention to dependent people, in order to revalue a clearly reviled element.

The study was developed over a year (2016-2017) and the collaboration of various areas of the city council involved, among others, the areas of Social Services, Elderly People, as well as the area of Equality were sought.

We were interested in factors such as intimacy and complicity, which allow us to discover, in more detail and with greater depth, aspects that they considered relevant and transcendental within their own experience, which is why it is essential Realize it not only individually, but also in spaces where the interviewee felt comfortable and safe. To promote a climate of confidence that would allow to gather not only the speeches but also the silences that could sometimes be loaded with information. 
The initial forecast (when designing the study) was to make a total of 13 to 15 semi-structured interviews. For the interviews were elaborated scripts with general and/or specific topics that should be treated to obtain the information we considered significant. And that if the person interviewed did not address them, the interviewer was in them. This methodology meant that each interview could complement the previous and give rise to the following in a sort of research puzzle that would allow to contrast, and complement the information provided by each of the men interviewed.

In the interviews the emotional, the affective, the personal, turned out to be the key element. They were endogenous interviews, since the gaze was more subjective since it was born from within the interviewed individual; Therefore it turned out to be, at the same time, more introspective.

The interviews were distributed in the following way:

- 11 men caregivers of dependent persons (who are within the dependency system as caretakers or in phase of recognition of this condition), one for each of the 11 social service centers Municipalities in which the city is organized.

. 2 or 4 (would depend on the level of saturation of the information), professionals responsible for the processing and follow-up of the unit that, therefore, were in contact with the caregivers.

In practice this initial forecast was overwhelmed by the interest shown by the Professional staff (especially the social workers) in participating in the study. This has allowed us to extend the most professionalized vision. In this way, in the end a total of 26 interviews were carried out between caregivers and professionals (social workers) covering all the districts of the city.

What we present here shows the information collected, especially of the men caregivers and, of beginning, indicates to us that the care is to be covered in part or in its entirety depending on various factors (deterioration cognitive and physical both of the person Caregiver as well as the person cared for by members of the immediate environment, such as the family. This care comes from an explicit demand or not, and a claim of the "collection" of favors made in the past: "You took care of me, now it's my turn to take care of you." This implies an affective situation that in many cases men, by the patriarchal mandate received have seen severed.

Traditionally the task of caring has been assigned to women and, therefore, has been disparaged since the patriarchal parameters, but with the increase of the life expectancy, the men assume the tasks of the care and they do, sometimes, with the conviction of Return the received. Not in all men or in all situations in a homogeneous way, as we have observed through research, there are generational factors, that is, younger generations assume in a more favorable way the responsibility of the Care. Likewise, the generations of male caregivers usually cope in the worst way that task even though they assume it more as a duty of correspondence towards (in general their mothers).

The main conclusion that is highlighted in the investigation is that the care contributes a value both to the individual who exerts it and to the one who receives it; And it brings an obvious benefit to the collective (care economy). 
From these parameters, little by little, the men who gradually exert it, do so with the satisfaction of the duty fulfilled. They change their way of acting once, by necessity, their perception of care has changed. And that modification was only by exercising and to reflect that before it was reviled as the own of women, it actually possesses an intrinsic value of greater human draught.

On the other hand, some men -still slowly but continuously- are building a new social reality. Certain new ways of interacting with their family environment and also have to do with the revaluation of employment and the discovery of welfare through care.

To the observed, at present, it is necessary to understand the care more as a social and political matter and not only as once, when it was considered a private matter and of women (Comás, 2016: 19). This gives us the possibility of a new social stage in which the traditionally accepted roles can and should be modified. It is not plausible in societies that are increasingly egalitarian, that men continue without being actively involved in activities that were traditionally assigned to women, but whose gender distinction is currently anachronistic.

\section{INTRODUCCIÓN}

La motivación principal de la presente investigación tiene su origen en el estudio de los cuidados a las personas adultas dependientes. Cuando ese cuidado es informal, se le atribuye a la familia, y, más concretamente, se responsabiliza a las mujeres del cuidado. Es crítico situar la génesis de esta situación en el contrato social suscrito en la Era Moderna, pues ese contrato se asentó, y permanece en muchos aspectos en la actualidad, en la diferenciación entre una esfera pública, la configuración del Estado donde se establece el marco de derechos y deberes de la ciudadanía, y una esfera privada, que cubre las necesidades íntimas de los individuos. Ese contrato social fue, en realidad, un contrato sexuado (Pateman citado por Carrasco y Cia, 2011) pues se atribuyeron los derechos universales de la ciudadanía a los hombres y se relegó a las mujeres al ámbito privado, al cuidado de la ciudadanía. Todo ello sancionado por la Filosofía Moderna y Romántica (vg. Rousseau y Hegel) y el Derecho que de ahí deriva para la constitución del nuevo Estado. En la presentación del libro "el trabajo de cuidado", de Cristina Carrasco, Crsitina Borderias y Teresa Torns (2011), nos dejan clara la relación entre cuidados y política: "La organización social de los trabajos de cuidados y el lugar que ocupan en la sociedad actual son producto de un largo proceso histórico que comenzó a gestarse durante la transición al capitalismo liberal." (15).

Es necesario y relevante poner en cuestión el desigual reparto de derechos y obligaciones que están en la base del contrato social que sustentan a los actuales Estados de las sociedades capitalistas. En la actualidad, aunque muy len- 
tamente, estas situaciones comenzaron a cambiar con el Estado del Bienestar gracias a múltiples agentes y actores sociales y políticos, entre las que cabe destacar las reivindicaciones de los derechos de las mujeres como ciudadanas impulsadas por los feminismos. Un ejemplo reciente en nuestro país fue la publicación de la Ley 39/2006, de 14 de diciembre, de Promoción de la Autonomía Personal y Atención a las personas en situación de dependencia -más conocida como ley de dependencia- que mostró la necesidad de regularizar la situación que los procesos relacionados con el cuidado de las personas dependientes generan. Otro agente relevante para revertir la organización social del cuidado es el rol que los hombres, actores políticos disculpados históricamente de esta labor, comiencen a participar, de los cuidados. Es en este punto donde nuestra investigación comienza.

En investigaciones anteriores del equipo de trabajo (Rodríguez y Marín, 2015), se pudo observar como algunos hombres desempleados revisaban ciertos principios que consideraban (y les habían hecho creer que eran) inmutables tales como la idea de "el salario del hombre debía mantener a la familia mientras que el de la mujer sólo era para ella misma o como suplemento del familiar (segundo sueldo)." (Alcañiz, 2015: 103) Así, en la actualidad, el valor que posee el empleo tiene el interés que se merece. Pero ahora convive con otros, que no poseían valor cuando eran hombres trabajadores en activo. Nos referimos a algunos tales como el valor del cuidado tanto de sí mismo (valoración de la salud propia), como de los demás miembros de la familia, de la relación de pareja (al permitirse compartir actividades reveladoras y gratificantes), y de los-as hijos-as (al estar presentes en su proceso de crecimiento y crianza), así como también en el cuidado de las personas ancianas de su entorno (ESECÉ, 2009; Figueroa et alí, 2006; Merla, 2006).

A fin de conocer más sobre los procesos de los cuidados a personas dependientes, en el área de estudios sobre nuevas masculinidades de la Universitat de València, en el que se inserta esta investigación, se ha planteado poner el foco en las figuras masculinas que, por diferentes motivos, asumen este rol de cuidador. El interés del equipo que firma el proyecto está en indagar qué les aporta a los hombres ser cuidadores y en conocer como se sitúan ellos en las relaciones que establecen con las personas dependientes. Asumiendo los cambios que los hombres están adoptando en los roles tradiciones que les eran asignados, como se ha explicado en el párrafo anterior, se tomó la decisión analítica de tomar conceptos de organizaciones sociales previas a la formación del Estado. Así, para la estructuración y comprensión de las relaciones de cuidado se observó que un instrumento explicativo vehicular válido podía ser la teoría de la reciprocidad y el intercambio que desarrollaron autores como Mauss, 
Polanyi, Levi-Strauss o Sahlins, entre otros, conceptos que "han sido utilizados para captar la ambigüedad de unas relaciones que parecían depender de la acción simultánea de fuerzas 'económicas' (interés material, distribución racional de discursos) y 'extra-económicas' (moral, emocional, 'social')" (Narotzky, 2016-2007: 79-80).

Claro que el uso del concepto de reciprocidad en nuestra sociedad puede ser problemático. En primer lugar, en esta investigación se desarrolla la observación relacional en una sociedad occidental moderna y no en sociedades primitivas, como sí hicieron los autores clásicos mencionados. En segundo lugar, a pesar de que somos conscientes que desde la denominada Economía feminista se ha logrado cuantificar el cuidado, como una manera de legitimar un trabajo que estaba socialmente invisibilizado, el intercambio que analizamos aquí, se produce entre elementos inmateriales (cuidados por elementos afectivos), sin exponer necesariamente una reciprocidad desinteresada. En sí, que la relación económica que motivó a los autores citados puede quedar aquí algo deslavazada. El amplio trabajo sobre reciprocidad aplicado a las sociedades actuales de Susana Naroztky nos refuerza para superar los problemas mencionados:

Todo esto y más son algunos de los problemas que se nos han ido planteando a medida que intentábamos entender una serie de relaciones sociales y de flujos de recursos (políticos y económicos) que de una manera general nos parecían enmarcarse más en lo que llamamos relaciones de «reciprocidad» que en relaciones económicas de «mercado» o en relaciones políticas de derechos y deberes explícitos y normativos de la ciudadanía liberal o en relaciones sociales contractuales de todo tipo (en donde las partes enumeran y describen explícitamente los términos de las transferencias e implícitamente excluyen todo el resto de posibles transferencias). (2002: 17)

Así pues, partimos de ese constructo teórico clásico, la reciprocidad, pero aportando una mirada diferente y complementaria. Por lo que, al ser conscientes de las diferencias indicadas, vamos a tratar de controlar en que puede condicionar al resultado.

\subsection{La reciprocidad en el cuidado, la relectura de un término clásico en antropología}

Cuando se habla de reciprocidad, se hace referencia a una característica que es común a todas las sociedades humanas, un tipo de intercambio donde no hay mercado que delimita su valor. Dicho esto, no existe una única definición del término, si bien, "[e]sta amplia noción incluye tres características principales, a saber, la obligación de devolver en el futuro -esto es: no inmediatamente-, los beneficios recibidos de una forma no predeterminada" (Molina 
y Alayo, 2002: 166). Para Karl Polanyi, la reciprocidad no son más que "movimientos entre puntos correlativos" y junto con otros conceptos como son el de mercado y el concepto de redistribución, suponen formas de integración en la sociedad. De la misma manera, entendemos que con el proceso de cuidado por parte de los hombres, estos pueden integrar una idea más igualitaria de sociedad. La reciprocidad, según el concepto clásico de Marshall Sahlins viene referida a aspectos materiales y a un modelo de intercambio proto-económico (de sociedades primitivas) ${ }^{2}$, si bien reconoce la existencia de una "reciprocidad generalizada", que se refiere a transacciones consideradas altruistas y que Malinowski también reconocía denominándolo "don puro". Otras denominaciones etnográficas son "compartimiento", "hospitalidad", "don libre", "ayuda" y "generosidad" (Sahlins, 1983: 212).

En el momento en que la reciprocidad permite una relativización de sí y de otro, que tiende hacia un estado intermedio equilibrado, el resultado es un sentimiento de pertenencia a una humanidad común. Pero esta relativización puede ser desequilibrada si uno de los polos domina al otro. Pero se reequilibra cuando se entiende el cuidado como un elemento de valor social necesario.

Susana Narotzky, siguiendo a Polanyi, plantea la diferenciación tácita entre la ayuda mutua y la reciprocidad. La ayuda mutua es la que establecen las partes con un objetivo concreto (i.e. recoger la cosecha) y se extingue la obligación de ayuda mutua cuando se cumple lo acordado; se entiende así que la ayuda mutua es, en esencia, un contrato implícito. La reciprocidad, en cambio, se refiere a un contexto social cuyo ordenamiento moral produce una serie de obligaciones que no se extinguen en el cumplimiento de las expresiones discretas de estas obligaciones (la reciprocidad filial, por ejemplo). Sin embargo, con frecuencia la ayuda mutua puede ser una expresión de reciprocidad (Narotzky, 2002: 18). Por tanto, nos vamos a referir a la reciprocidad en un sentido amplio, donde se incorporen elementos de intercambios materiales e inmateriales y donde se incorpore un concepto de ayuda mutua con un valor de intercambio.

En este sentido debemos reconocer cómo la reciprocidad no siempre supone un intercambio de uno por uno. De hecho, existe, un continuado complejo de variaciones en la espontaneidad y equivalencia del intercambio (Sahlins en Godelier, 1976). Aun reconociendo lo que muchos autores ya han detectado (Carrasco, Borderías y Torns, 2011; García-Calvente, M. del M. et al., 2004),

\footnotetext{
2 Aunque la reciprocidad también se ha analizado en otros contextos más "modernos" como son la burguesía urbana contemporánea y las sociedades postsocialistas (para una mayor información véase Han, 2006).
} 
esto es, que el cuidado supone un tiempo y una dedicación que se ha llegado a cuantificar económicamente, al igual que a nivel de intercambios entre elementos materiales. Pero nos quedamos con la idea de que puede que no esté compensado cuantitativamente el intercambio.

Además, el vínculo que se establece a través de la reciprocidad, de alguna manera, es mucho más fuerte que los simples contratos, en tanto que cuando el deber y la responsabilidad entran en juego, la reciprocidad estricta apela al sentido común y a las expectativas humanas que el contrato no puede proporcionar (Terradas, 2002).

En síntesis, nuestra relectura de la reciprocidad destaca tres elementos: Uno, en un sentido amplio, en la reciprocidad, los valores del intercambio son también inmateriales y recoge connotaciones de la ayuda mutua; dos, no hay, necesariamente, equivalencia en el intercambio; $y$, tres, en un sentido estricto, la reciprocidad establece un vínculo que un contrato no puede proporcionar.

\subsection{El cuidado, ¿una versión modernizada de intercambio inmaterial?}

\subsubsection{El cuidado}

Los individuos somos interdependientes, por lo que el cuidado es una tarea necesaria en todos los ámbitos y en todos los niveles de la vida humana. Sin embargo, "hay muchos cuidados y muchas dependencias que no vienen "nombradas", por lo que se invisibilizan." (Cierri y Alamillo-Martínez, 2012: 11). Pero la Ley 39/2006, al reconocer en su exposición de motivos que:

"[H]an sido las familias, y en especial las mujeres, las que tradicionalmente han asumido el cuidado de las personas dependientes, constituyendo lo que ha dado en llamarse el «apoyo informal». Los cambios en el modelo de familia y la incorporación progresiva de casi tres millones de mujeres, en la última década, al mercado de trabajo introducen nuevos factores en esta situación que hacen imprescindible una revisión del sistema tradicional de atención para asegurar una adecuada capacidad de prestación de cuidados a aquellas personas que los necesitan." (BOE, 2006: 44142)

Con esta ley, se logró un cambio relevante al depositar la mirada en quienes hasta entonces no habían sido visibilizadas, las familias y, en especial, las mujeres, las cuales en relación a la atención de las personas dependientes, "son las grandes perjudicadas de la inexistencia de un sistema público de esta naturaleza, tanto desde su condición de personas en situación de dependencia como en la de cuidadoras de éstas, ya que desempeñan una función en la familia en donde las relaciones de sus individuos están institucionalizadas" (Martínez en Díaz, 2007: 140). Dicha situación, implica, sin duda, el reconocimiento de un 
cierto fracaso puesto que si las mujeres siguen encargándose del trabajo reproductivo, ocupando socialmente el lugar de "cuidadoras", esto conlleva que los hombres, mayoritariamente continúen exentos de la sobrecarga lo que supone una distribución sexista de la responsabilidad de los cuidados (ESECÉ, 2009). De hecho parece que "es la misma estructura laboral la que está creando un nuevo segmento para que las mujeres permanezcan en el mercado laboral y a la vez sigan con sus responsabilidades de cuidado." (Alcañiz, 2015: 113)

Los hombres que cuidan, hasta ahora, reconocen que para ello deben aceptar perder los privilegios derivados de los roles tradicionales, pero todo indica que necesariamente se debe "implicar a la otra parte", ya que sin los hombres difícilmente podrá corregirse una desigualdad que opera especialmente con total impunidad en el espacio privado (Covas, 2009).

El tema de los hombres como cuidadores es un tema relativamente poco estudiado en España. En líneas generales, suele estar centrado, sobre todo, en el cuidado de la prole (Figueroa et allí., 2006; Alberdi y Escario 2007), pero está mucho menos analizado el cuidado informal de los hombres hacia las personas dependientes, el aspecto que aquí nos interesa.

Hay que considerar también que, las motivaciones que tiene una persona para convertirse en cuidadora, poseen un componente social y un componente personal (Delicado, 2006). La posición en la estructura social es importante en la medida en que los individuos asumen las expectativas normativas que derivan de su posición en las instituciones sociales (familia y mercado, fundamentalmente). El sexo de la persona y la posición familiar son determinantes, por supuesto, en la configuración de esas expectativas. Sobre el componente personal, ni que decir tiene que toda acción entre personas propicia una relación afectiva. No es un mero intercambio de bienes o servicios, comporta una implicación afectiva que, por tanto, afecta tanto a la persona que lo ejerce como a la persona receptora del cuidado.

Aquí, es necesario precisar qué se entiende por "cuidado" puesto que es un término que a lo largo de los años ha ido cobrando importancia y según algunas autoras resulta un tema central en la academia (Carrasco, Borderías y Torns, 2011). Como indican estas autoras desde una perspectiva sociológica, el cuidado supondría "un complejo proceso de tareas, trabajos y energías, cuyo objetivo sería la reproducción de la población y de las relaciones sociales" (2011: 31). Al mismo tiempo, Rogero García, señala que las fronteras del cuidado informal son "imprecisas y se considera condición indispensable en su definición la no existencia de contrato por las partes o relación laboral previamente acordada, aunque pueda ser remunerado o compensado de manera ocasional" (2010: 40). 
Los diferentes autores no logran consensuar un significado de la palabra "cuidado", que evite la actual imagen parcial y fragmentada que actualmente posee el concepto. En este sentido, Carol Thomas intentó buscar una definición de acuerdo, al indicar que los cuidados son:

La prestación remunerada o no remunerada de apoyo en la cual intervienen actividades que implican un trabajo y estados afectivos. Los prestan principal, pero no exclusivamente, mujeres, tanto a personas adultas sanas, como a personas dependientes y a los niños y las niñas, en la esfera pública o en la esfera doméstica, y en una diversidad de marcos institucionales. (Thomas en Carrasco, Borderías y Torns, 2011: 169).

El cuidado como se puede observar en la definición de Thomas, intenta abarcar la multitud de repercusiones que tiene en las esferas de la vida de las personas cuidadoras y las cuidadas. Al mismo tiempo, los efectos negativos que el cuidado tiene en la sociedad en general se han diferenciado, de manera resumida, entre costes sociales o costes económicos (Rogero, 2010: 56).

Los cuidadores informales son personas que forman parte de la red social de la persona con dificultades: familiares, amigos o vecinos (Yanguas, Leturia y Leturia, 2000), se parte, pues, de un vínculo. Este vínculo se afianzará más o menos dependiendo del grado de cercanía o lejanía que exista en esa relación de parentesco. Así mismo, los cuidados informales componen siempre una relación afectiva entre el cuidador y la persona dependiente (García, Mateo y Eguiguren, 2004) o, al menos, se establecen ciertos vínculos afectivos basados en el conocimiento previo que se tenía de la otra persona (Herrera, 1998).

La experiencia de cuidar, involucra una gran responsabilidad y un enorme esfuerzo, provoca un aumento en la carga de la persona cuidadora. Esa carga puede traer repercusiones físicas, mentales y socioeconómicas ${ }^{3}$. Y, por lo tanto, compromete la vida, la salud, el bienestar, el cuidado y autocuidado no sólo de la personas cuidadoras (que se refleja, por ejemplo, en el denominado síndrome de carga (Blanco, et ali.2017)), sino también de la persona dependiente de cuidados, por lo que se requiere de un soporte social integral. Como se ha investigado desde la Sociología del género (Gálvez, Rodríguez y Domínguez, 2010), hay que superar la tradicional asignación de roles dependiendo del género según la cual, "han sido las mujeres uno de los principales sectores de población objeto de atención por parte del Trabajo Social (...) como interlocutoras ante las problemáticas que se plantean en el seno de las familias, conse-

${ }^{3}$ En este sentido resulta de interés la distinción que algunos estudios hacen entre el caring for (cuidar de alguien) y el caring about (ocuparse de alguien) (Bobinac, Van Exel, Rutten y Brouwer, 2010). 
cuencia directa del rol cuidador que se les asigna." (Berasaluce, 2009: 133) para poder avanzar en lo que se ha venido en denominar "Brecha de cuidados" (Díaz y Simó-Noguera, 2016)

Una vez revisadas algunas ideas que están en la base del cuidado que histórica y socialmente se les ha asignado a las mujeres de las familias cuidadoras y toda la carga que esta situación genera, regresamos al concepto de reciprocidad para recargarlo con estas aportaciones. Entendemos que existe una revisión del concepto de reciprocidad a la luz de la importancia que tienen, en la actualidad, las redes de apoyo informal de las personas dependientes para las políticas de Bienestar Social (Litwin, 1996). Consideramos que existe una reciprocidad inmaterial que surge del nexo y la obligatoriedad del intercambio que se da en el entorno que, como ya hemos comentado, es de la familia, amigos o vecinos; y que como también hemos recogido, esta situación vendrá acompañada por aspectos relacionados con la ética y los sentimientos y no tanto por cuestiones directamente vinculadas con lo económico. Es en este punto donde la definición que da Susana Narotzky nos resulta idónea puesto que ofrece un concepto "vago" que describe "transferencias entre individuos o grupos y que insinúa una motivación moral aunque no totalmente carente de interés material." (Narotzky, 2016-2007: 80) Esta definición vincula tanto la motivación moral como el interés material que consideramos que también está presente en la ayuda mutua.

\subsubsection{El intercambio inmaterial}

A fin de reasignar el concepto de cuidado como un intercambio inmaterial, junto con los matices introducidos hasta ahora, establecemos un diálogo con autores clásicos y sus conceptos para ver que podemos recoger de la tradición antropológica Para Marcel Mauss, en su obra Ensayo sobre el Don, el intercambio en las sociedades analizadas consistía básicamente en tres obligaciones: dar, recibir y devolver. En este autor, este intercambio supone la base de las relaciones económicas. Por el contrario, en el trabajo que aquí se expone, vamos a tomar esa base para observar un intercambio no necesariamente económico, sino más bien de índole afectivo. Nos resulta de interés puesto que el intercambio no es material sino a partir de elementos inmateriales como es el cuidado. Si bien existe toda una línea de investigación en torno a la denominada economía del cuidado, no es el marco teórico en el que nos basamos.

Continuamos el diálogo con la línea señalada por Claude Lévi-Strauss en su obra Las estructuras elementales del parentesco. En esta obra indica que "[e]n nuestra sociedad considerara ciertos bienes que carecen de un valor esencial de consumo, pero a los que les atribuimos un gran precio psicológico, estético 
o sensual (tales como las flores, los bombones o los "artículos de lujo")...." (Lévi-Strauss, 1966/1988: 95). De esta manera, damos valor a ciertos elementos que no son esencialmente de consumo, pero que entendemos que aportan un beneficio no cuantificable (por ejemplo, en cuanto a calidad de vida). De esta manera ponemos en relación esta idea con el término de familismo el cual "se asocia con consecuencias positivas para el afrontamiento del cuidado, dado que se observa un alto grado de implicación de la familia en la resolución de conflictos que afectan a uno de sus miembros." (Losada, Montorio, et ali.2006: 59).

Hemos apuntado una serie de conceptos que nos ayudan a comprender cuáles son las relaciones que establecen los hombres cuidadores con las personas que cuidan, más allá de la relación de parentesco y observado como intercambio inmaterial. A este fin se ha diseñado una investigación basada en entrevistas abiertas tanto a hombres cuidadores como a profesionales del cuidado de la dependencia.

\section{METODOLOGÍA. LA RELEVANCIA DEL MÉTODO CUALITATIVO PARA CAPTAR LA EMERGENCIA DEL CUIDADO MASCULINO}

La investigación que respalda este artículo versa sobre el cuidado informal a la dependencia de personas adultas llevado a cabo por hombres y forma parte de una investigación realizada por un equipo multidisciplinar del área de nuevas masculinidades de la Universidad de Valencia. Este trabajo es un encargo del Área de Igualdad del Ayuntamiento de València, y se ha realizado entre 2016 y 2017 en la misma ciudad de València. Los dos objetivos generales del proyecto han sido analizar las percepciones, creencias y comportamientos de los hombres cuidadores así como identificar las resistencias y barreras socio-culturales que dificultan una mayor implicación de lo hombres en las tareas de los cuidados informales. Para afrontar esos objetivos, la metodología del proyecto ha integrado una encuesta a los hombres cuidadores con entrevistas cualitativas tanto a hombres cuidadores como a profesionales del trabajo social. A fin de contextualizar el material empírico recogido, se cuenta con los datos sociodemográficos y socio-sanitarios de la ciudad de Valencia.

En concreto, el presente artículo muestra los resultados obtenidos a través de las entrevistas abiertas realizadas a hombres cuidadores y a trabajadoras y trabajadores sociales. El análisis de dichas entrevistas se centra en indagar qué les aporta a los hombres cuidadores las tareas que comporta el cuidado a la dependencia y en conocer cómo se sitúan ellos en las relaciones que se establecen con las personas dependientes, contrastándolas con las percepciones y observaciones de la mirada institucional que aportan las y los profesionales del trabajo social. 
La privacidad del mundo del cuidado, requiere de una investigación cualitativa que permita emerger las características de un fénómeno invisibilizado, fuera de las esferas públicas, así como unas relaciones que nos son novedosas entre unos cuidadores no genérico, sino masculinos, y las personas cuidadas. La perspectiva es la que se recoge en la tradición de las epistemologías feministas que podemos sintetizar en la formulación de Sandra Harding (2008) de empezar la investigación y la política desde la vida de las mujeres, en este caso, desde su invisible espacio, los hogares: "In an older language one could ask why one should not start out from a central site of social and material reroduction to ask questions about projects of social and material production" (p. 256).

Dentro de la investigación socio-antropológica, elegimos la entrevista en profundidad. Luis Enrique Alonso plantea las entrevistas en profundidad como procesos comunicativos de extracción de la información en un contexto de investigación. Esta información, según Alonso, se encuentra en los datos biográficos de la persona entrevistada, puesto que "implica que la información ha sido experimentada y absorbida por el entrevistado y que será proporcionada con una orientación o interpretación que muchas veces resulta más interesante informativamente que la propia exposición cronológica o sistemática de acontecimientos más o menos factuales." (Alonso, 1998: 225-226). De este modo nuestra preparación del guión de la entrevista estaba motivada por conocer de qué manera experimentaban el mundo del cuidado, nos interesaban factores tales como la intimidad y la complicidad, que nos permitieran ir descubriendo, conjuntamente a las personas investigadas e investigadoras, aspectos que ellos consideraban relevantes y trascendentales dentro de su propia experiencia. Para este fin, era indispensable realizar la entrevista de forma individual y en espacios donde el entrevistado se sintiera cómodo y seguro. También en el caso de las y los profesionales, fue relevante asegurar un espacio donde se sintieran cómodos para reflexionar acerca de perspectivas que en su trabajo diario no eran las habituales.

Junto con la justificación de la oportunidad de la investigación cualitativa para hacer emerger el conocimiento de los cuidados desde la privacidad y la intimidad, una última idea que es relevante exponer, antes de entrar a la descripción del trabajo de campo realizado, es la de los niveles de aproximación a la realidad que establece Susana Narotzky (2016-2007). Si esta autora ya nos orientaba en como usar la reciprocidad en sociedades actuales, también nos da ciertas claves para afrontar su análisis mediante los diferentes "niveles de aproximación a la realidad" que establece: "1) descriptivo de los flujos de transferencia observables (tangibles o intangibles pero materiales) que se dan en este marco alternativo al contrato formal, 2) descriptivo de los discursos de los actores sobre la «razón» de las transferencias, sobre las obligaciones que 
las sustentan y las obligaciones que producen, 3) descriptivo de los conceptos de los «expertos» que analizan la sociedad (estudiosos, políticos) a menudo para intervenir en el sentido de su reproducción o transformación y por último, 4) descriptivo de los modos de intervención de las instituciones políticas y económicas formales en la organización de estos flujos de transferencias" (16). Estas indicaciones nos permiten estructurar nuestro trabajo en estos diferentes niveles con la información que hemos obtenido de las entrevistas en profundidad a hombres cuidadores y a profesionales del trabajo social.

Se realizaron entrevistas en profundidad a once hombres cuidadores de personas en situación de dependencia, o bien que se encontraran dentro del Sistema de Dependencia como cuidadores o en fase del reconocimiento de esta condición. Esta previsión de cantidad de individuos vino determinada para cubrir cada uno de los 11 Centros de Servicios Sociales Municipales en los que está organizada la ciudad, lo que a su vez, nos permitía, asegurarnos cubrir geográficamente todo el universo urbano. Se utilizaron estos centros para seleccionar y contactar con los hombres cuidadores. El primer contacto se realizaba por teléfono, en cuya conversación se le presentaba el estudio y se le preguntaba por su interés en participar en la investigación. Desde un principio se le comunicaba el tratamiento confidencial de la información que él transmitiera y que no aparecerían datos que pudieran sacarle del anonimato, al mismo tiempo que se dejaba claro que asegurar el anonimato y mantener la confidencialidad era una obligación del equipo de investigación. A su vez, también, se le indicaba que el equipo de investigación no se iba a entrometer en el trabajo de los profesionales del Centro Municipal de Servicios Sociales, que la investigación no tenia relación con la asistencia y ayuda que recibía desde ese Centro. Se trató siempre que entendieran que no era un servicio más y que no favorecería su participación en ningún tipo de servicio prestado por el Centro. Una vez que aceptaban su participación, eran los hombres cuidadores seleccionados los que elegían el momento y el lugar donde realizar las entrevistas, indicándole que la duración no se ría inferior a dos horas.

Es importante para el análisis de estas entrevistas tomar en consideración elementos de la estructura social (edad, nivel de estudio, situación laboral) a fin de contextualizar la capacidad de acción de los individuos entrevistados que nos ayude a distinguir elementos propios de agentes. Pero más relevante es situar la relación formal de parentesco entre cuidadores y personas cuidadas, en tanto que la reciprocidad se asienta en vínculos sociales, en este caso en el de parentesco. Así como, y en estrecha relación con ello, si se da una situación de convivencia. En la siguiente tabla 1 se describe la información mencionada con la etiqueta de cada entrevistado que se usará e la exposición de resultados del siguiente apartado del artículo. 
Tabla 1. Descripción social cuidadores entrevistados

\begin{tabular}{|c|c|c|c|c|c|}
\hline $\begin{array}{l}\text { Entrevistados } \\
\text { (etiqueta) }\end{array}$ & Edad & Niv. Estudios & Sit. Laboral & $\begin{array}{c}\text { Rel. } \\
\text { Parentesco }\end{array}$ & $\begin{array}{c}\text { Convivencia } \\
\text { (S/N) }\end{array}$ \\
\hline Ent cuid1 & 56 & Universitario & $\begin{array}{l}\text { Incapacidad } \\
\text { Permanente }\end{array}$ & Hijo-madre & $\mathrm{S}$ \\
\hline Ent cuid 2 & 76 & FP & Jubilado & Marido & $\mathrm{S}$ \\
\hline Ent cuid 3 & 73 & $\begin{array}{l}\text { Bachillerato } \\
\text { Elemental }\end{array}$ & Jubilado & Marido & S \\
\hline Ent cuid 4 & 55 & $\begin{array}{l}\text { Estudios } \\
\text { primarios }\end{array}$ & Desempleado & Hijo-madre & $\mathrm{S}$ \\
\hline Ent cuid 5 & 51 & $\begin{array}{l}\text { Estudios } \\
\text { primarios }\end{array}$ & Desempleado & Hijo-madre & S \\
\hline Ent cuid 6 & 78 & $\begin{array}{l}\text { Certificado } \\
\text { Escolaridad }\end{array}$ & Jubilado & Padre-hija & $\mathrm{S}$ \\
\hline Ent cuid7 & 56 & FP & Desempleado & $\begin{array}{l}\text { Yerno- } \\
\text { suegra }\end{array}$ & $\mathrm{S}$ \\
\hline Ent cuid 8 & 37 & FP & Trabajando & $\begin{array}{l}\text { Yerno- } \\
\text { suegra }\end{array}$ & $\mathrm{S}$ \\
\hline Ent cuid 9 & 55 & $\begin{array}{l}\text { Certificado } \\
\text { Escolaridad }\end{array}$ & Desempleado & Hijo-Padre & $\mathrm{S}$ \\
\hline Ent cuid 10 & 66 & Bachiller & Jubilado & Marido & $\mathrm{S}$ \\
\hline Ent cuid 11 & 69 & $\begin{array}{l}\text { Estudios } \\
\text { Primarios }\end{array}$ & Jubilado & Marido & $\mathrm{S}$ \\
\hline
\end{tabular}

Respecto a las voces profesionales, se planteó inicialmente realizar entre dos o cuatro entrevistas a profesionales responsables de la tramitación y seguimiento de la dependencia que, por tanto, estuvieran en contacto con los hombres cuidadores. En este caso, la cantidad de entrevistas a realizar dependería del nivel de saturación de la información. Pero, en la práctica, esta previsión inicial quedó desbordada ante el alto interés mostrado en participar en el estudio por las trabajadoras y los trabajadores sociales. Finalmente se realizaron 15 entrevistas a profesionales, lo que nos permitió distribuir las entrevistas también entre todos los Centros de Servicios Sociales Municipales: en cuatro centros se entrevistaron a dos profesionales, y, en los siete restantes, a una persona, tal y como recoge la tabla 2.

Las quince entrevistas al personal profesional se realizaron en los propios centros de trabajo y en horarios de descanso, dentro de su horario laboral. Si bien, se han realizado todas estas entrevistas al personal profesional, y se respetarán las diferentes manifestaciones de los quince profesionales, somos 
Tabla 2. Distribución de las entrevistas realizadas al personal profesional

\begin{tabular}{c|c|c}
\hline & $\begin{array}{c}\text { Centro Municipal de } \\
\text { Servicios Sociales }\end{array}$ & $\begin{array}{c}\text { Profesional-s } \\
\text { entrevistado }\end{array}$ \\
\hline 1 & Benimaclet & 2 \\
\hline 2 & Salvador Allende & 1 \\
\hline 3 & Olivereta & 2 \\
\hline 4 & Malvarrosa & 1 \\
\hline 5 & Campanar & 1 \\
\hline 6 & Quatre Carreres & 1 \\
\hline 7 & Sant Marcel·lí & 1 \\
\hline 8 & Trafalgar & 2 \\
\hline 9 & Patraix & 1 \\
\hline 10 & Nazaret & 2 \\
\hline 11 & Ciutat Vella & 1 \\
\hline & TOTAL & $\mathbf{1 5}$ \\
\hline
\end{tabular}

conscientes de que sus respuestas presentan un discurso más homogéneo y coherente con la realidad profesional que observan día a día, y de que tienen menor variabilidad. Por ello, en el presente documento, hemos priorizado las voces de los cuidadores frente a la información aportada por los y las trabajadoras sociales. Esto ha implicado que presentemos más cortes de los cuidadores que de las profesionales. Si bien, en nuestro análisis las voces profesionales se usaran como contrapunto corrector a los discursos recogidos de las personas (los hombres cuidadores) que viven la problemática in situ, y es fuente básica para estudiar las relaciones entre las personas cuidadoras y cuidadas.

\section{RESULTADOS DEL ESTUDIO. ¿SE ENCUENTRA MARCEL MAUSS ACTUALIZADO EN LOS HOMBRES CUIDADORES?}

Marcel Mauss afirmaba en su obra Ensayo sobre el Don que es a través del intercambio cuando se generan potentes vínculos sociales, ya que quien recibe un 
don -según la terminología de Mauss- está obligado de tal manera que, sólo se puede liberar de esa obligatoriedad adquirida, a través de un contradon. Y si bien es cierto que "reciprocidad", "don" e "intercambio" son formas que pueden estar presentes en diferentes situaciones sociales, sean igualitarias, sean "tributarias" o redistributivas"." (Abduca, 2007: 120), optaremos en ese estudio entender por reciprocidad como un intercambio recíproco de un bien inmaterial que se aporta de manera informal entre parientes cercanos. Aunque, siempre hemos de entender que en otros marcos teóricos también se entiende como un producto mercantilizado en la denominada "economía del cuidado" (Carrasco, 2011; Diaz y Simó-Noguera, 2016).

La actitud frente el cuidado es vivenciado de manera muy diferente según dos factores clave: la intensidad del intercambio según la mayor o menor cercanía de parentesco entre la persona cuidadora y la persona cuidada, y en esto nos acercamos a lo expuesto por Mauss. Y, por otro lado, una diferenciación de actitudes más o menos positivas hacia el cuidado según la edad, que nos lleva a pensar en una brecha generacional. Esta idea la reforzamos con el punto de vista aportado por una de las Trabajadoras Sociales:

Sí que se establecen cambios, pero repito los hombres de más de cincuenta se sienten muy perdidos en estas cosas del cuidado. Y toleran muy mal que su mujer que era la que organizaba y cuidaba ahora de repente, ya no es la que era. (T.S. 2)

La vinculación entre la reciprocidad, el don y el contradón se puede observar cuando se habla con los hombres entrevistados y señalan directamente esa relación de reciprocidad que se establece entre cuidador y persona cuidada, bien sea en la previsión de un cambio futuro (si me ocurriera a mi....): «Intento ser el mejor cuidador que puedo ser con mi esposa y mi hija, porque sé que mi esposa lo haría por mí». (E.11) Bien sea reconociendo la "deuda" moral que tiene contraída con ella siguiendo, por tanto, la idea del "toma y daca" que presentaba Lévi-Strauss cuando afirmaba que se opera según el doble ritmo de dar y recibir: «Lo he dado todo. Igual que mi madre lo ha dado todo por mí, y lo sigue dando. Por eso la cuido». (E.5)

A su vez, el hecho de cuidar, implica elementos que van más allá de lo meramente intercambiable, son en palabras de Claude Lévi-Strauss, "vehículos e instrumentos de realidades de otro orden" (1988: 93): «Mientras yo pueda, quiero cuidarla yo (...) vivo por ella». (E.6)

Al mismo tiempo se observa, al igual que en la teoría de Mauss, cierta asunción de un alto compromiso que supone la responsabilidad de devolución, ya no tanto de un elemento material como de un fundamento inmaterial: «Yo pienso que es un papel que tengo que asumir y que tengo que hacer». (E.3) 
En esto también coinciden algunas de las trabajadoras sociales entrevistadas:

Tengo en mente a un hombre que está super, super, super cuidando a la mujer como entre algodones, que yo le riño a veces y le digo: "vale, espabila que esto no puede ser", que me dice: "es que creo que ahora le estoy devolviendo todo lo culpable que me siento de lo golfo que he sido en esta vida"... ime entiendes? Y aún me comentaba que: "...Y aún me siento mal, porque a veces me enfado". (T.S. 4)

Además, según el planteamiento de círculos concéntricos de Sahlins, "la reciprocidad se inclina hacia el equilibrio o el subterfugio, en proporción con la distancia sectorial" (1983), de ahí que el nivel de responsabilidad sea visto como un deber cuando el cuidador es el cónyuge y la persona cuidada, en situación de dependencia, sea la esposa: «Yo sé que tengo un deber y obligación, y lo tengo que cumplir... $»$ (E.2)

Pero, también, cuando la relación entre el cuidador y la persona en situación de dependencia es una relación entre hijo-madre: «Es una obligación que... digamos que tú tienes que hacerlo. Te cansas, te enfadas...eh...te alteras, pero lo tienes que hacer». (E.9)

La reciprocidad, afirma Sahlins (1983), resulta un continuo que va desde un intercambio desinteresado hasta el interés por uno mismo y, finalmente, pasa por la mutualidad. En el caso de las personas cuidadoras de personas en situación de dependencia (esposas, esposos, madres, padres, suegras, hijas-os) se puede percibir ese intercambio desinteresado de un bien inmaterial a través de lo que conocemos como familismo mostrando la existencia de fuertes sentimientos de lealtad, reciprocidad y solidaridad entre los miembros vinculados por los lazos familiares:

A una madre hay que cuidarla. (E. 5)

Es un miembro más de la familia,... en la familia no es solo tu mujer. (E. 8) Es mi obligación y lo tengo que hacer, me he comprometido, no con nadie, conmigo mismo, y cuando usted se compromete consigo mismo, es cuando más tiene que obedecer. (E. 11)

Si bien este intercambio no resulta del todo desinteresado puesto que existe un contradon en ese intercambio inmaterial y afectivo, como es el amor y el cariño que se genera:

A partir del cariño que le tengo, ahora soy más consciente de sus necesidades. (E.1)

Te hace tener una sabiduría, ves la vida desde otra perspectiva diferente a la de los demás. Es una experiencia muy importante... (E. 8)

Lo más importante es que siga habiendo afecto, cariño y amor, eso es lo más importante. (E. 10) 
También es evidente que interfiere en la vida personal y laboral del cuidador y su entorno, como ocurre en situaciones de cuidado similares:

Sí que interfiere, por supuesto que interfiere, pero vamos... (E. 9)

Sí, claro...al cuidarlo a él...pues me ha cambiado todo, todo radicalmente todo.

Ya te digo, desde poder tú desenvolverte yéndote tú por ahí...simplemente a dar una vuelta,...cambia, porque, con él, en cuanto te das la vuelta... (E. 9)

En la vida sí que tengo menos libertad, eso sí, porque yo soy de los que no paro. (E. 11)

Teniendo a veces una experiencia vivencial muy negativa, «[e]sto es un sufrimiento continuo (...) es una tarea sin fin». (E.3)

Si hemos convenido que, para Marshall Sahlins, la reciprocidad generalizada es el extremo solidario, entonces estamos hablando de transacciones altruistas, o "don puro", que se presentan, en términos morales, como generosidad. "Estos intercambios tienen su origen en deberes de parentesco. Sin embargo, este "don puro" genera una contraobligación" (Sahlins, 1983: 212).

De esta manera, si bien la situación de cuidado puede servir para reforzar lazos ya existentes entre cuidador y persona cuidada, «[e]l vínculo es muy grande con mi madre...y ver que cada vez se va apagando, no lo asumes... muchas veces te derrumbas». (E. 5), así como « [s]i se empeora mi esposa, empeoro yo». (E. 11)

En ocasiones, y siguiendo a Sahlins (1983), puede que una de las partes del intercambio considere que este no se ha efectuado "uno por uno", es por tanto, un intercambio desigual. De esta manera, el compromiso se vive mal: «La convivencia, esto es un mata-personas. Así de claro». (E. 7) Y « [1]a verdad es que...no me ha enseñado nada». (E. 3)

Pero, al final, el hecho en sí, se concreta en que los hombres cuidadores entrevistados responden de manera negativa cuando se les indaga sobre la opción de llevar a sus parientes a una residencia, lo consideran como una especie de "traición" ética:

Es...mi mujer, no la puedo abandonar, ni la puedo llevar a ningún sitio, sino que tengo que estar aquí con ella...hasta que pueda. (E.2)

Yo a mi madre no la llevo, porque sé que ella no quiere ir...primero es mi madre. (E. 4)

Mientras yo pueda, física y mentalmente mi madre no irá a ningún sitio de esos porque no...prefiero cuidarla yo. (E.5)

Inclusive considerándose al cuidador como la mejor opción de cuidado frente a la residencial: «La residencia soy yo, ¿qué mejor residencia?»(E. 11) 


\section{DISCUSIÓN: UN CAMBIO QUE NO LO ES TANTO}

Ignasi Terradas afirmaba que "La reciprocidad es siempre para algo, que la inspira y supera a la vez. (...) lo cual la ha forzado a ser interpretada en términos de interés" (Terradas, 2002: 227 y 229). A nuestro parecer, Terradas indica, de esta manera, la inexistencia real del desinterés en el intercambio, puesto que en realidad siempre se pretende "algo". Esto queda reflejado en las entrevistas realizadas. Con lo cual, sí puede existir un factor económico indudable cuando el cuidador se ha quedado sin ingresos y recurre a la pensión de la persona que cuida, como hemos podido observar en el caso de algunos hijos. Así, una de las trabajadoras sociales señala:

Hay hombres que han solicitado la ley de la dependencia (sic), estaban en el paro y han dicho: "voy a cobrar la ayuda vinculada a cuidado no profesional" (T.S.1)

Aunque, la misma trabajadora social reconoce que también ha podido observar, a lo largo de su carrera profesional, casos en los que el marido asume la situación como un deber y una obligación, pero con amor y responsabilidad:

En el caso de otro cuidador él tenía también una patología muy grave y, sin embargo, estaba volcándose en su mujer. No nos damos cuenta, pero muchas veces son cincuenta años de casados y pasa como a segundo plano su propia enfermedad. (T.S.3)

El resultado de nuestro análisis nos permite contemplar la existencia de una ambivalencia de sentimientos "encontrados", por un lado, la opción entre el deber y el sentimiento de obligación y, por el otro i?cual? En el fondo, se puede observar como ambos sentimientos se complementan en un binomio casi perfecto que se analiza a partir de ciertos discursos adaptativos de hombres cuidadores:

Y en la vida no todo tiene que ser bonito. (E. 8)

Si no existiera el mal no podría apreciar el bien. Para que aprecies una cosa, tiene que haber otra contraria... el ser humano tiene que estar siempre en un descontento, en el sentido de que siempre tienen que faltar cosas. (E. 10)

Se advierten los intercambios sociales, que crean una obligación de devolver de forma no definida en el futuro. Este efecto es donde los lazos familiares y/o de amistad expresan la existencia de una reciprocidad "aplazada" (Rogero-García 2010): implica que la persona mayor ha ofrecido sus ayudas en el pasado y ahora solicita la devolución, o esta se le ofrece voluntariamente (Cerri, 2013: 11). Existe todavía reciprocidad porque se trata de algo que empezó en el pasado y que hay que continuar. 
Puesto que estos intercambios se desarrollan en la esfera doméstica, siguiendo la teoría de Marcel Mauss, intuimos en los hombres entrevistados -los cuales antaño fueron cuidados (don), y en el presente son cuidadores- una obligación (responsabilidad moral) hacia la persona que en la actualidad cuidan (contradon).

He visto de un marido que ha dicho: "vamos a provechar, ya que tengo una pensión, vamos a irnos de viaje, vamos a irnos a tal, vamos a disfrutar" y eso que a veces ella presenta síntomas puntuales de conductas alteradas, pero él está ahí con su mujer, para lo que haga falta. Disfrutando juntos hasta el último momento. (T.S.4)

Con todo, esa relación de reciprocidad sólo es posible mantenerla a lo largo de un tiempo. Puesto que, tal y como nos han indicado algunas de las profesionales entrevistadas, al contrastar el discurso de los hombres cuidadores con sus experiencias como trabajadoras sociales, conforme se alarga el tiempo de vida de la persona cuidada, el nivel de renuncias por parte del cuidador también aumenta y, por tanto, el intercambio resulta más desigual:

Se establecen unos lazos de afecto que yo creo que no había antes. (...) El que una persona frágil dependa de tu ayuda, moviliza emociones y existe un periodo en el que te sientes gratificado, pero a la larga quema (...) porque el cuidador no puede asumir ese cuidado, el cuidado en casa resulta cada vez más complicado, tus renuncias son cada vez mayores y más prolongadas en el tiempo. (T.S. 3)

\section{CONCLUSIONES}

El macrocontexto que conocemos de la situación de cuidados está marcado por el inexorable envejecimiento de la población y, con el actual trance socioeconómico, la incapacidad de la red de servicios públicos para poder cubrir la totalidad de necesidades que la población anciana demanda, y progresivamente irá demandando, genera una situación, cuanto menos, compleja. Esta realidad necesita de un mayor conocimiento de los microcontextos, de la circunstancia que aportan los actores del cuidado. Una aproximación a estos microcontextos, los ha ofrecido esta investigación centrada en estudiar la forma de reciprocidad dentro del entorno familiar. El cuidado ha de ser cubierto en parte o en su totalidad dependiendo de diversos factores (deterioro cognoscitivo y físico tanto de la persona cuidadora como de la persona cuidada) por miembros del entorno más inmediato, como es la familia. A ese cuidado se llega por una demanda explicitada o no, y una reclamación del "cobro" de favores realizados en el pasado: "tú me cuidaste, ahora me toca a mí cuidarte". Esto impli- 
ca una situación afectiva que en muchos casos los hombres, por el mandato patriarcal recibido han visto cercenada. De esta manera, asumir la carga de ese cuidado permitirá a los hombres recuperar ese afecto tradicionalmente negado.

Ahora bien, el punto fundamental, es que la tarea de cuidar ha sido tradicionalmente asignada a las mujeres y, por tanto, ha sido menospreciada desde los parámetros patriarcales donde la valorización residía en las tareas masculinas del ámbito productivo.

Pero la realidad demuestra que, con el aumento de la esperanza de vida, los hombres asumen las tareas del cuidado y lo hacen, en ocasiones, con la convicción de devolver lo recibido. No en todos los hombres ni en todas las situaciones de manera homogénea, como hemos observado a través de la investigación realizada, coexisten factores generacionales, esto es, las generaciones más jóvenes asumen de una manera más favorable la responsabilidad del cuidado. Así mismo las generaciones de hombres cuidadores suelen sobrellevar de peor (un reflejo de ello es el denominado síndrome de carga) manera esa tarea aunque lo asumen más como un deber de correspondencia hacia (en general sus madres).

En cualquier caso, podemos afirmar que el cuidado aporta un valor al individuo que lo ejerce y al que lo recibe; y aporta un beneficio evidente al colectivo (economía del cuidado). Desde estos parámetros, poco a poco, los hombres que paulatinamente lo van ejerciendo, lo hacen con la satisfacción del deber cumplido y, por tanto, es preciso señalar como en la sociedad altamente interrelacionada como es la nuestra, las relaciones son relativamente estables entre las partes del conjunto, y esa estabilidad deriva de la permanencia de los actos sociales más allá de las personas (Merton, 1954/2002). Y esa estabilidad y esas interrelaciones se desarrollan a través del intercambio recíproco.

Por último, es necesario reconocer que este trabajo ha tenido limitaciones habida cuenta que se trataba de una investigación cualitativa con una muestra reducida. Aun así, esperamos que abra la puerta a futuros estudios que atiendan a muestras más amplias y diferentes casuísticas.

\section{BIBLIOGRAFÍA ACTUALIZADA}

Abduca, R.G. (2007): "La reciprocidad y el Don no son la misma cosa." Cuadernos de Antropología Social, 26: 107-124. Recuperado en: http://www.scielo.org.ar/pdf/cas/n26/n26a06.pdf

Alberdi, I. y Escario, P. (2007). Los hombres jóvenes y la paternidad. Bilbao, Fundación BBVA.

Alcañiz, M. (2015). "Crisis, precariedad y desigualdad de género en España y en Italia." OBETS. Revista de Ciencias Sociales, 10 (1): 97-125.

Doi: 10.14198/OBETS2015.10.1.04 
Alonso, L.E. (1998). La mirada cualitativa en sociología. Madrid, Editorial Fundamentos. Berasaluce, A. (2009) "El devenir del trabajo social en clave de género". Revista de Servicios Sociales Zervitzuan, 46: 133-140. doi: 10.5569/1134-7147

Blanco V, Guisande, M. A.; Sánchez, M. T.; Otero, P.; López, L. y Lino, F. (2017): "Síndrome de carga del cuidador y factores asociados en cuidadores familiares gallegos." Revista Española de Geriatría y Gerontología. https://doi.org/10.1016/j.regg.2018.03.005

Bobinac, A.; Van Exel, N.J.; Rutten, F. y Brouwer, W. (2010) "Caring for and caring about: Disentangling the caregiver effect and the family effect" Journal of Health Economics, 29: 549-556.

Carrasco, C. (2011). "La economía del cuidado: planteamiento actual y desafios pendientes." En Revista de economía crítica, 11: 205-225. Recuperado en: http://revis taeconomiacritica.org/n11

Carrasco, C, Borderías, C y Torns, T. (2011). El Trabajo de cuidado. Historia, teoría y políticas. Madrid: Los libros de la Catarata.

Cerri, C. (2013). "El impacto de los servicios públicos de cuidado a mayores en una zona rural de Extremadura." En Gazeta de Antropología, 29 (2): 1-18. Recuperado en: http://www.gazeta-antropologia.es/?p=4304

Cerri, C. y Alamillo-Martinez, L. (2012) "La organización de los cuidados, más allá de la dicotomía entre esfera pública y esfera privada." En Gazeta de Antropología, 28 (2): 1-23. Recuperado en: http://www.gazeta-antropologia.es/?p=4145

Comas, D. (2016): "Hombres cuidadores: Barreras de género y modelos emergentes". En Psicoperspectivas, Vol 15, núm. 3, pp. 10-22.

Comas, D. (2015). "Los cuidados de larga duración y el cuarto pilar del sistema de bienestar." En Revista de Antropología Social, 24: 375-404. Recuperado en: https://revistas.ucm.es/index.php/RASO/article/view/50663

Comas, D. (2014). "La crisis de los cuidados como crisis de reproducción social. Las políticas públicas y más allá." En Periferias, fronteras y diálogos. XIII Congreso de Antropología de la Federación de Asociaciones de Antropología del Estado Español. Tarragona, 2-5/09/2014 Tarragona, Univ. Rovira i Virgili, 329-349.

Covas, S. (2009). Hombres con valores igualitarios. Madrid, Ministerio de Igualdad.

Delicado, V. (2006). "Características sociodemográficas y motivación de las cuidadoras de personas dependientes. ¿Perfiles en transición?” En Praxis sociológica. 10: 200234. Recuperado en: http://www.praxissociologica.es/index.php/numeros-publicados

Díaz, R. M. (2007). "Feminización de la dependencia. Reflexiones sobre el sistema para la autonomía y la atención a personas en situación de dependencia." En Portularia: revista de trabajo social, 7 (1-2): 139-156. Recuperado en: http://hdl.handle.net/10272/574

Díaz, C. y Simó-Noguera, C. (coord.) (2016) Brecha salarial y brecha de cuidados. Valencia, Editorial Tirant lo Blanch.

ESECÉ (2009). Los hombres y el cuidado de la salud. Madrid, Ministerio de Sanidad y Política Social. 
Figueroa, J. G. (y otros) (coord.) (2006). Ser padres, hijos, esposos, México DF, El Colegio de México.

Gálvez, L., Rodríguez, P. y Domínguez, M. (2010). Género, trabajos y usos del tiempo en España dentro del contexto europeo. En Villar, A. (coord.) Mujeres y mercado laboral en España: cuatro estudios sobre la discriminación salarial y la segregación laboral. Madrid: Fundación BBVA: 83-138.

García-Calvente, M. del M., Mateo-Rodríguez, I y Eguiguren, A.P. (2004). "El sistema informal de cuidados en clave de desigualdad." En Gaceta Sanitaria, 18 (4):132-139. Recuperado en: http://scielo.isciii.es/scielo.php?script=sci_arttext\&pid=S0213-9111 2004000400021

Harding, Sandra (2008). Sciences from Below: Feminisms, Postcolonialities, and Modernities. Durham: Duke University Press.

Hann, Ch. (2006). "The gift and reciprocity: perspectives from economic anthropology." En S.Ch. Kolm y J.M. Ythier (Eds.) Handbook of the economics of giving, altruism and reciprocity vol. 1. Noth-Holland. Elsevier.

Herrera, M. (1998). "Nuevos desafíos en políticas sociales: la community care." Revista Española de Investigaciones Sociológicas, 82: 249-281. Recuperado en: http://www.reis.cis.es/REIS/jsp/REIS.jsp? opcion=articulo\&ktitulo=1344\& autor=MANUEL+HERRERA+G\%D3MEZ

Lévi-Strauss, C. (1966/1988). Las estructuras elementales del parentesco, Barcelona, Editorial Paidós.

Litwin, H. (ed.) (1996). The Social Networks of Older People: A Cross-National Analysis. London, Praeger Publishers.

Losada, A.; Montorio, I; Izal, M. y Márquez, A. (2006): Estudio e intervención sobre el malestar psicológico de los cuidadores de personas con demencia. El papel de los pensamientos disfuncionales. Madrid: Instituto de Mayores y Servicios Sociales (IMSER$\mathrm{SO})$

Mauss, M. (1980). "Essai sur le don. Forme et raison de l'échange dans les sociétés archaïques." En Socilogie et Anthropologie, Paris, Press Universitaíres de France.

Merla, L. (2006). "«No trabajo y me siento bien»: Cambios en la división sexual del trabajo y dinámicas identitarias de padres en casa en Bélgica." En Cuadernos de Relaciones Laborales, 24 (2): 111-127. Recuperado en: https://revistas.ucm.es/index.php/CRLA/article/view/CRLA0606220111A

Merton, R. (1954/2002). Teoría y Estructura sociales. México, Fondo de Cultura Económica.

Molina, J. L. y Alayo, A. (2002). "Reciprocidad hoy: La red de las unidades domésticas y los servicios públicos en dos colectivos en Vic." ENDOXA, 15: 165-181. Recuperado en: http://revistas.uned.es/index.php/endoxa/article/view/5043

Narotzky, S. (2016-2007). "El proyecto en el modelo: Reciprocidad, capital social y la política del realismo etnográfico." En (Con)textos, Revista d'antropologia i investigación social, 6 74-99. Recuperado en: http://revistes.ub.edu/index.php/contextos/ article/view/15322 
Narotzky, S. (2002). "Reivindicación de la ambivalencia teórica: La reciprocidad como concepto clave." ENDOXA, 15: 15-29. Recuperado en: http://revistas.uned.es/index.php/endoxa/article/view/5033

Rodríguez, J. A. y Marín, S. (2015). "Ampliando la mirada en antropología de género: hombres en conflicto con un modelo de masculinidad. El caso de parejas con hombres desempleados y mujeres trabajadoras". En I Congreso Internacional de Antropología AIBR. Madrid, julio de 2015.

Rogero-García, J. (Dir.) (2010). Los tiempos del cuidado: el impacto de la dependencia de los mayores en la vida cotidiana de sus cuidadores. Madrid, IMSERSO.

Rossell, T. (1988). L'entrevista en el treball social. Barcelona, Editorial EUGE.

Sahlins, M. (1983). Economía de la Edad de Piedra. Madrid: Editorial Akal.

Sahlins, M. (1974/1976) "Economía tribal”. En Maurice Godelier (Editor) Antropología y parentesco. Barcelona, Editorial Anagrama, 1976: 233-259.

Taylor, S.J. y Bogdan, R. (1984/1994). Introducción a los métodos cualitativos de investigación. La búsqueda de significados. Barcelona, Editorial Paidós.

Terradas, I. (2002). "La reciprocidad superada por la equidad, el amor y la amistad." ENDOXA, 15: 205-249. Recuperado en: http://revistas.uned.es/index.php/endoxa/ article/view/5046

Terradas, I. (2002). "Is reciprocity an enlightening concept to address contemporary issues?" ENDOXA, 15: 33-41. Recuperado en: http://revistas.uned.es/index.php/ endoxa/article/view/5034

VV. AA. (2006): "LEY 39/2006, de 14 de diciembre, de Promoción de la Autonomía Personal y Atención a las personas en situación de dependencia” En Boletín Oficial del Estado, 299: 44142-44156.

Verdú, A. D. (2014). "El amor en la sociedad de consumo", Gazeta de Antropología, 30 (1): 1-14. Recuperado en: http://hdl.handle.net/10481/31068

Yanguas, J (y otros) (2000). "Apoyo informal y cuidado de las personas mayores dependientes.” Papeles del Psicólogo, 76: 23-32. Recuperado en: http://www.papelesdel psicologo.es/resumen?pii $=836$ 


\section{BREVES NOTAS BIOGRÁFICAS}

JUAN A. RODRÍGUEZ DEL PINO: Doctor en Estudios de Género, Licenciado en Geografía e Historia y Licenciado en Antropología Social y Cultural. Es profesor de la Universidad de Valencia. Imparte docencia en el área de Sociología. Investiga sobre temas de Género (especialmente las Masculinidades) y Desarrollo Local (desempleo, brecha salarial, etc.) Tiene diversas publicaciones sobre dichos temas.

http://orcid.org/0000-0002-2585-741X

TERESA SAMPER MAS: Licenciada en Sociología y Ciencias Políticas por la Universitat Autónoma de Barcelona, postgraduada en Comunicación científica por la Universitat Pompeu Fabra. Profesora de Sociología en la Universitat de València. Su docencia gira entorno a la metodología y técnicas de investigación social cuantitativas. Sus investigaciones ponen en relación género y ciencia.

SUSANA MARIN TRAURA: Diplomada y Graduada en Trabajo Social y Diplomada y Graduada en Educación Social. Profesora de la Universidad de Valencia, imparte docencia en materias vinculadas a los grados de Pedagogía y Educación Social, así como en el Master de Acción Social y Educativa. Ha trabajado en Servicios Sociales en distintas AA.PP.

ENRIC SIGALAT SIGNES: Doctor en Sociología, Diplomado en Trabajo Social y Licenciado en Sociología. Es profesor de la Universidad de Valencia. Imparte docencia en materias vinculadas a las Técnicas de Investigación Social (Cuantitativas) y Sociología del Trabajo. Ha participado en diversos estudios y proyectos tanto en el sector público como en el privado.

ANA ELISA MORENO RUÍZ: Graduada en Pedagogía y Doctoranda en Estudios de Género y Políticas de Igualdad. Ha trabajado con menores en riesgo de exclusión a través de diversas ONG's. y en centros de reeducación.

Recibido: 17-10-2017

Aceptado: 05-10-2018

\section{(c) (i) Licencia Creative Commons Reconocimiento (CC BY 4.0)}




\section{NORMAS EDITORIALES E INSTRUCCIONES PARA COLABORACIONES}

A continuación se ofrece un resumen de las normas editoriales e instrucciones para colaboraciones. Se recomienda consultar la última versión disponible en la dirección http://revistaobets.ua.es Instrucciones para el envío de originales

1. OBETS. Revista de Ciencias Sociales tiene como objetivo la difusión de estudios de naturaleza académica que permitan un mejor conocimiento de la sociedad contemporánea. En este sentido

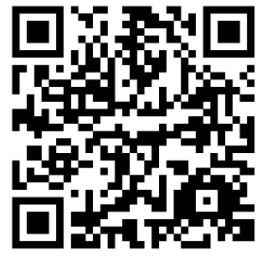
está abierta a la publicación de resultados de investigación empírica, metodológica o teórica de ámbito nacional e internacional, en un amplio abanico de temas inscritos en el ámbito de la Sociología y Ciencias Sociales, como estudios de opinión pública, metodología, demografía, estructura y cambio social, ciencia política, teoría sociológica, antropología o psicología social. Se dará prioridad a trabajos que comuniquen resultados de investigaciones académicas originales y que observen la estructura IMRyDC+B (introducción, metodología, resultados y discusión, conclusiones, y bibliografía actualizada).

2. Los trabajos, que podrán estar escritos en español, inglés, portugués o valenciano/ catalán deberán ser remitidos en formato digital, como archivo adjunto en formato .rtf o .doc a través de la página de envíos en la web de la revista. La recpción de artículos está abierta durante todo el año, a excepción del mes de agosto.

3. En cada edición se aceptan artículos que han sido positivamente evaluados al menos durante el mes anterior al de edición.

4. La extensión de los artículos que se remitan a la revista tendrán una extensión no superior a 10.000 palabras. Las notas de investigación (informe de hallazgos, aportaciones, etc.) tendrán una extensión máxima de 7.000 palabras. Las recensiones o críticas de libro no pueden superar las 3.000 palabras, y debe especificarse en ellas el autor, el título, la editorial, el lugar y la fecha de publicación de la obra objeto de recensión, así como el nombre, los apellidos y la dirección de contacto del autor de la crítica. Sólo se aceptarán recensiones de libros publicados en los últimos 3 años.

5. Los trabajos se enviarán en el siguiente formato

1. Tipo de letra Times New Roman, tamaño 12. Espacio sencillo, tamaño de página DIN A4.

2. Los diferentes apartados irán en negrita, en mayúsculas sólo la primera letra y con el mismo tipo y tamaño de fuente que el cuerpo del texto.

3. Los párrafos irán sangrados en la primera línea.

4. Las palabras en idioma diferente al original del trabajo deben ir en cursiva.

5. Las citas textuales deben ir entrecomilladas cuando sean inferiores a tres líneas. Si tienen más de 3 líneas irán sin entrecomillar y sangradas por el margen izquierdo, indicando en todo caso entre paréntesis el apellido del autor o autores del texto, el año de publicación y la página. Por ejemplo: (Ramírez, 2009: 10). Si hay más de dos autores pero menos de seis, se citarán todos ellos la primera vez y las veces siguientes se usará la expresión "et al.". Si son más de seis autores, se usará "et al." desde la primera mención. 
6. Para la bibliografía, al final del trabajo, deberá utilizarse el estilo APA (American Psychological Association). A continuación se ofrecen algunos ejemplos de formato:

\section{Libros y capítulos:}

Anwar, M. (1979). The Myth of Return: Pakistanis in Great Britain. London: Heinemann.

Esser, H. (2003). "What substance is there to the term 'Leitkultur'?". En R. Cuperus, K. A. Duffek y J. Kandel (Eds.), The challenge of diversity. European social democracy facing migration, integration and multiculturalism. Innsbrück/Vienna: Studienverlag, 47-58.

\section{Revistas:}

Berry, J. W. (1970). "Marginality, stress, and ethnic identification in an acculturated Aboriginal community". Journal of Cross-Cultural Psychology, 1, 17-22. Para documentos online, debe indicarse la fecha de consulta. Cuando se incluyan varias referencias de un mismo autor/a, es necesario indicar el nombre del autor en cada título y no usar guiones/rayas.

7. Las imágenes y diagramas se incluirán en el texto. En función de la resolución y calidad de dichas imágenes, la redacción puede solicitar el envío posterior de los archivos de imagen originales como condición para su publicación.

8. Los trabajos deben incluir, tanto en la lengua del artículo como en inglés, los siguientes elementos básicos: título, resumen de no más de 100 palabras, y entre 4 y 8 palabras clave separadas por punto y coma. Si el idioma del trabajo es el inglés, se incluirán estos elementos en inglés y en español. Para aquellos textos cuyo idioma sea diferente del inglés se debe enviar, además del abastract de 100 palabras, un abstract extendido en inglés del orden de 1000 a 1500 palabras en el que se describa con algo más de profundidad los métodos, datos, hallazgos e implicaciones del trabajo.

6. Los artículos han de ser inéditos. Dicha condición debe indicarse durante el proceso de envío al completar la lista de comprobación en la plataforma de la revista.

7. Las propuestas de contribuciones enviadas a la revista OBETS no pueden ser enviadas simultáneamente a ninguna otra publicación.

8. Todo original se somete al arbitraje por pares académicos. Con la finalidad de garantizar la imparcialidad en la selección de los artículos para publicar, se observa el anonimato tanto de autores como de evaluadores. Para proteger este anonimato, se respetará el siguiente formato en los trabajos enviados:

1. Una primera página en la que constará, únicamente, el título (en mayúsculas la primera letra y el resto en minúsculas), el nombre y apellidos de los autores, el centro de trabajo, dirección postal y correo electrónico, y teléfono y fax en su caso.

2. Una segunda página que contenga, nuevamente, el título, un resumen de no más de 100 palabras, y entre 4 y 8 palabras clave, separadas por punto y coma. Tanto el título como el resumen y las palabras clave deben aparecer en la lengua del trabajo y en inglés. 
3. El texto del trabajo (incluyendo el abstract extendido en inglés) en la página tercera y siguientes.

\section{Proceso de selección de originales}

1. Las obras recibidas pasarán por el siguiente proceso en el que cada paso requiere la superación del anterior:

1. Notificación de acuse de recibo.

2. Clasificación temática del artículo (UNESCO). Al menos dos miembros del Consejo Editorial comprobarán que el trabajo cumpla los estándares editoriales de un texto académico en el ámbito temático de la revista. Si hay al menos una valoración positiva, el trabajo pasará a la siguiente fase, y en caso contrario será notificado de manera justificada a los autores.

3. Revisión de aspectos formales y estilos, con notificación y devolución al autor en caso de existir errores.

4. Comprobación de la anonimización del artículo.

5. Revisión por dos personas evaluadoras externas, de acuerdo con criterios de

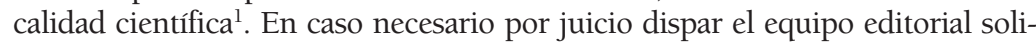
cita la contribución de un tercer evaluador/a. El formulario de evaluación está disponible en la web de la revista e incluye:

1. Evaluación de la originalidad y contribución científica.

2. Evaluación de la claridad y coherencia de objetivos, hipótesis, metodologías y conclusiones del trabajo.

3. Evaluación de la pertinencia y actualización de la bibliografía.

4. Evaluación de los aspectos formales (redacción, citas, organización del texto, tablas, gráficos, etc.)

5. Recomendación final sobre el trabajo y, en su caso, sugerencias de modificación o razones para no publicación.

6. Envío al autor del informe de revisión con la decisión correspondiente (aceptación, aceptación pendiente de rectificaciones, rechazo) de forma motivada en un plazo máximo de 6 meses desde la recepción del artículo.

2. En el caso de que un artículo sea aceptado para su publicación, se solicitará al autor/a la firma de un documento de cesión de derechos a fin de que sea publicado en la revista bajo licencia Creative Commons Reconocimiento 4.0 España (CC BY 4.0). De igual modo, las pruebas de imprenta serán enviadas al autor/a en formato PDF cuando estén disponibles y deberán ser devueltas a la secretaría de la revista en el plazo máximo de una semana, con las oportunas correcciones.

3. El proceso de evaluación suele tomar unos 4-6 meses. Al tratarse de una revista semestral, una vez aceptado un artículo la publicación final puede llevar por lo general hasta 6 meses más.

4. Para cualquier duda o aclaración, puede mandar un correo electrónico a la siguiente dirección: revistaobets@ua.es

\footnotetext{
${ }^{1}$ Centro de Información y Documentación Científica (CINDOC) CSIC. Madrid, 2001.
} 


\section{Principios éticos de publicación}

La publicación de artículos en una revista con revisión por pares es un reflejo directo de la calidad del trabajo de sus autores, y del compromiso y cualificación de los investigadores que actúan como revisores. Por ello OBETS. Revista de Ciencias Sociales es una publicación comprometida con los principios éticos de la actividad científica en los siguientes términos:

\section{Publicación y autoría}

Todos los artículos deben incluir un listado de referencias, así como indicar si han recibido apoyo económico. Los trabajos deben estar libres de plagio o fraude científico, cuyos supuestos ${ }^{2}$ se enumeran de manera no exhaustiva a continuación:

- Plagio: copia literal sin entrecomillar y citar la fuente; copia sustancial (materiales de investigación, procesos, tablas...); parafrasear o reproducir ideas sin citar la fuente y/o cambiando el significado original; reutilizar y enviar textos propios ya publicados sin indicar la fuente y el parafraseo abusivo incluso citando la fuente.

- Fraude científico: no reconocimiento de todos los investigadores/as participantes en la elaboración del trabajo, el envío simultáneo a varias publicaciones, la división de un trabajo en partes diferentes que comparten las mismas hipótesis, población y métodos, así como la utilización de datos falsos o no probados. Finalmente, los autores/as deben declarar a la revista los potenciales conflictos de interés cuando envían un trabajo.

\section{Responsabilidad de los autores}

- El envío de trabajos a OBETS supone la lectura y aceptación de las normas editoriales y de publicación de la revista, incluida la participación en un proceso anónimo de evaluación por pares.

- Todos los autores que firman un trabajo deben haber contribuido de manera significativa a su elaboración y deben estar de acuerdo con el resultado final y con el envío del trabajo para su evaluación.

- Los trabajos deben reconocer a todos los autores que han participado en su elaboración.

- Los datos utilizados en el artículo deben ser reales y auténticos.

- Los autores asumen la obligación de corregir y/o retractarse ante posibles errores detectados posteriormente.

- Los artículos han de ser inéditos y no pueden ser enviados simultáneamente a ninguna otra publicación.

\section{Proceso de revisión}

Todos los artículos enviados a la revista se someten a un proceso de revisión por pares con las siguientes características:

- La selección de los revisores se realiza en función de normas y principios previos basados tanto en su cualificación como en la calidad de su producción científica.

\footnotetext{
${ }^{2}$ Fuente: http://www.ethics.elsevier.com/
} 
- El proceso de revisión será totalmente anónimo tanto para los autores como para los revisores. Los artículos y sus revisiones serán tratados confidencialmente.

- Los revisores consideran, entre sus criterios de evaluación, el respeto a los principios éticos esenciales en la investigación científica.

- Los juicios expresados en las revisiones deben ser objetivos.

- Tanto autores como revisores deben revelar las relaciones y fuentes de financiación que puedan generar potenciales conflictos de intereses.

\section{Responsabilidades de los editores}

- El equipo editorial tiene la responsabilidad y autoridad para aceptar o rechazar un artículo basándose en las revisiones.

- El equipo editorial revelará en su caso las relaciones o fuentes de financiación que puedan ser potencialmente consideradas como conflictos de intereses respecto a los artículos que rechaza o acepta.

- Sólo se aceptarán los artículos en los que existe una evidencia cierta sobre el cumplimiento de las normas editoriales

- El Consejo de Redacción de OBETS. Revista de Ciencias Sociales se reserva el derecho de retirar cualquier trabajo recibido, aceptado o ya publicado en caso de constatarse plagio, falsificación o publicación duplicada, así como los diversos supuestos de fraude científico anteriormente enumerados. Del mismo modo, promoverá la publicación de correcciones o retractaciones frente a errores detectados.

- El equipo editorial se compromete a preservar el anonimato de los revisores de manera que nunca puedan asociarse con los artículos revisados.

\section{Cuestiones éticas de publicación}

El equipo editorial se compromete a:

- Vigilar y preservar los principios éticos de publicación

- Mantener la integridad del expediente académico

- Evitar la publicación de material plagiado o elaborado de manera fraudulenta

- Estar abierto a la publicación de correcciones, clarificaciones, retractaciones y disculpas siempre que sea necesario

- Ofrecer apoyo en el proceso de retractación de artículos

- Realizar todas las acciones necesarias para cumplir los estándares de compromiso intelectual y ético

\section{Aviso legal}

A efectos de lo estipulado en los artículos 138-143 de la Ley de Propiedad Intelectual, la publicación de un trabajo que atente contra dichos derechos será responsabilidad del autor/a. El equipo editorial de OBETS. Revista de Ciencias Sociales no se hace responsable, en ningún caso, de la credibilidad y autenticidad de los trabajos. Del mismo modo, las opiniones y hechos expresados en cada artículo son de exclusiva responsabilidad de sus autores/as y OBETS. Revista de Ciencias Sociales no se identifica necesariamente con ellos. Los autores conservan el copyright de su artículo sin restricciones. 



\section{EDITORIAL STANDARDS AND INSTRUCTIONS FOR CONTRIBUTORS}

Summary of guidelines for submitting manuscripts. Please check the latest version in http://revistaobets.ua.es

Guidelines for submitting manuscripts

1. The journal OBETS. Revista de Ciencias Sociales (OBETS. Journal of Social Sciences) aims at the dissemination of academic nature studies that allow a better understanding of contemporary society. In this sense it is open to the publication of results of empirical, methodological or theoretical research at national and

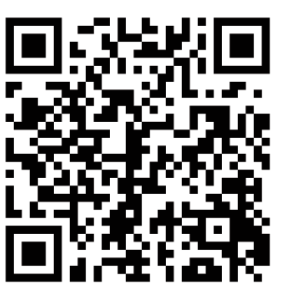
international level, in a wide range of subjects enrolled in the field of sociology and social sciences, as public opinion surveys, methodology, demographics, structure and social change, political science, sociological theory, anthropology or social psychology. Priority will be given to works that communicate results of original academic research and to use the IMR\&DC+B structure (introduction, methods, results and discussion, conclusions, and updated bibliography).

2. Papers may be written in English, Italian, Portuguese, Spanish or Valencian/Catalan. They must be submitted in digital format as an attachment, in .Rtf or .Doc format through the submission page on the website of OBETS Journal. Receipt of items is open all the the year, except August.

3. For each edition are accepted only articles that have been positively evaluated at least during the month prior to the edit month.

4. The length of papers should not exceed 10000 words. The research notes (report on findings, contributions, etc.) should not exceed 7000 words. The book reviews cannot exceed 3000 words, and should include the author, title, publisher, place and date of publication of the book. The full name and address of Contact of the author of the critique must also be included. We only accept reviews of books published in the last 3 years.

5. The works will be sent in the following format

1. Font Times New Roman, font size 12. Single space, page size A4.

2. Section headers in bold. Capitalize only the first letter, and with the same type and font size that the text body.

3. Paragraphs indented on the first line.

4. The words in a language other than the original work in italics.

5. Textual citations must be quoted if they are less than three lines. If you have more than three lines shall be indented by the left margin without quotation marks. In any case, indicate in parentheses the surname of the author or authors of the text, the year of publication and page. For example: (Ramírez, 2009: 10). If there are more than two authors but less than six, all of them will be cited the first time and the time following use the expression "et al.". If more than six authors, use "et al." from the first mention. 
6. The bibliography at the end of the work shall use APA style (American Psychological Association). Please find below some examples of format:

Books and chapters:

Anwar, M. (1979). The Myth of Return: Pakistanis in Great Britain. London: Heinemann.

Esser, H. (2003). "What Is There Substance to the term 'Leitkultur'?". In R. Cuperus, KA Duffek and J. Kandel (Eds.), The challenge of diversity. European Social Democracy Facing Migration, integration and multiculturalism. Innsbruck / Vienna: Studienverlag, 47-58.

Journals:

Berry, J. W. (1970). "Marginality, stress, and ethnic identification in an acculturated Aboriginal community". Journal of Cross-Cultural Psychology, 1, 17-22.

For documents online, you must indicate the accessed date.

When several references of a same author are included, it is necessary to indicate the name of the author in each title instead of using hyphens/dashes.

7. Pictures and diagrams should be included in the text. Depending on the resolution and quality of the images, the Journal can ask for the original image files as a condition for the publication.

8. Papers should include the following basic elements, both in the language of the article and in English: title, an abstrat no longer than 100 words, and between 4 and 8 keywords separated by semi-coma. If the working language is English, these elements should be included in English and Spanish. If the paper is written in a language other than English, in addition to the 100 words abstract, an extended English abstract must be included, on the order of 1000-1500 words, going into some depth about the papers methods, data, findings and implications.

6. Articles must be unpublished. That condition should be declared during the sending process, when completing the checklist in the Journal webside.

7. Proposals for contributions sent to the OBETS journal may not be sent simultaneously to any other publication.

8. All original is submitted to arbitration by academic peers. In order to ensure impartiality in the selection of articles to publish, the journal observes the anonymity of authors and evaluators. To protect the anonymity, please respect the following format in contributions:

1. A first page that contain only the title (capitalize the first letter and the rest in lower case), the name of the authors, the workplace, and email address, telephone and fax.

2. A second page containing, again, the title (but not the name of author/s), an abstract no longer than 100 words, and between 4 and 8 keywords, separated by semi-coma. Title, abstract and keywords should appear in the original language and in English. 
3. The text of the work (including the extended English abstract) will follow in the third and following pages.

\section{Selection process of manuscripts}

1. The works received will go through the following process in which each step requires overcoming previous

\section{Acknowledgement Notice}

2. Subject classification of the article (UNESCO). At least two members of the Editorial Board will check the compliance of the article with editorial standards of an academic text in the subject area of the journal. If there is at least a positive assessment, the article proceeds to the next phase; otherwise it will be justifiably notified to authors.

3. Review of formal aspects and styles, with notice and return to the author in case of errors.

4. Verification of the anonymization of the article

5. Review by two external evaluators, according to scientific quality criteria ${ }^{1}$. If necessary by disparate evaluations, editorial team requests the contribution of a third evaluator. The evaluation form (available on the website of the journal) includes:

1. Evaluation of the originality and scientific contribution.

2. Evaluation of the clarity and consistency of objectives, hypothesis, methodologies and conclusions.

3. Evaluation of the adequacy and updating of the bibliography.

4. Evaluation of the formal aspects (writing style, quotes, text organization, Tables, graphics, etc).

5. Final recommendation on the work and, where appropriate, suggestions for change or reasons for non-publication.

6. The author(s) will be notified with the relevant decision (acceptance, acceptance pending revisions, reject) on a reasoned way within a maximum period of 6 months.

2. When an article is accepted for publication, the author will be asked to sign a transfer of rights document in order to allow the journal to publish the article under a Creative Commons Attribution 4.0 Spain license (CC BY 4.0). Similarly, proofs will be sent to the author in PDF format when they are available and they must be returned to the secretariat of the journal within one week, with appropriate corrections.

3. The evaluation process is expected to last about 4-6 months. Since Obets Journal is semmianual, the final publication of the article once accepted usually can take up to 6 more months.

4. For any questions or doubts, please send an email to the following address: revistaobets@ua.es

${ }^{1}$ Centre for Scientific Information and Documentation (CINDOC) CSIC. Madrid, 2001. 


\section{Publication ethics and malpractice statement}

The publication of articles in a peer-review journal is a direct reflection of the quality of the work of their authors, and the commitment and qualifications of the researchers who act as reviewers. Therefore OBETS. Revista de Ciencias Sociales is a publication committed to the ethical principles of scientific activity in the following terms:

\section{Publication and authorship}

All manuscripts must include a list of references, and indicate whether they have received financial support. Works must be free of plagiarism or scientific fraud. Illustrative cases ${ }^{2}$ of plagiarism and scientific fraud can be consulted in a non-exhaustive list below:

- Plagiarism: literal copy without quoting and referencing the source; substantial copying (research materials, processes, tables...); paraphrasing or reproducing ideas without citing the source and/or changing the original meaning; text-recycling (reusing a published own text) without indicating the source, and abusive paraphrasing even quoting the source.

- Scientific fraud: no recognition of all the participating researchers in the study, simultaneous submission to several publications, the division of a work in different parts ('slices') that share the same hypotheses, population and methods, as well as the use of false or unproven data. Finally, the authors should disclose potential conflicts of interest to the journal when a manuscript is sent.

2. Responsibility of the authors

- The manuscripts submission to OBETS involves reading and acceptance of the journal publishing guidelines, including participation in an anonymous peerreview process.

- All authors signing a work must have contributed significantly to its development and must agree both with the end result and with the manuscript submission for evaluation.

- Manuscripts must acknowledge all authors who have participated in their elaboration.

- Data used in the article must be real and authentic

- The authors assume the obligation to retract/correct when possible errors are later detected.

- Articles must be original and cannot be sent simultaneously to any other publication.

\section{Review Process}

All articles submitted to the journal are subjected to a peer review process with the following characteristics:

- The selection of reviewers is done according to rules and principles based on both their qualification and the quality of their scientific production.

- The review process will be totally anonymous both for authors and for reviewers. Manuscripts and reviews will be treated confidentially.

\footnotetext{
${ }^{2}$ Source: http://www.ethics.elsevier.com/
} 
- Reviewers will take into account for their evaluation criteria the respect for the ethical principles that are essential in scientific research.

- The judgments expressed in the reviews should be objective.

- Authors and reviewers should disclose all relationships and funding sources that could generate potential conflicts of interest.

\section{Responsibilities of Editors}

- The editorial board has the responsibility and authority to accept or reject a manuscript based on the peer reviews.

- The editorial board will reveal any relationships or funding sources that could potentially be considered conflicts of interest regarding the rejection or the acceptance of manuscripts.

- The journal only accepts manuscripts when reasonably certain of compliance with editorial standards.

- The Editorial Team reserves the right to remove any received, accepted or already published work where plagiarism, falsification, duplicate publication or scientific fraud is found. Similarly, it will encourage the publication of retractions or corrections to errors detected.

- The editorial team is committed to preserve the anonymity of the reviewers so that they can never be associated with the reviewed manuscripts.

\section{Publishing ethical Issues}

The editorial board is committed to:

- Monitoring and maintaining the publishing ethics

- Maintaining the integrity of the academic record

- Avoid publishing plagiarized or fraudulently prepared material

- Be willing to publish corrections, clarifications, retractions and apologies when needed

- Provide support in the process of retracting articles

- Perform all actions required to meet the standards of intellectual and ethical commitment

\section{Disclaimer}

Regarding the provisions in articles 138-143 of the Spanish Law on Intellectual Property, the publication of a work prejudicial to those rights shall be the responsibility of the author. The editorial team of OBETS. Revista de Ciencias Sociales is not responsible, in any case, for the credibility and authenticity of the works. In the same way, the opinions and facts expressed in each article are the sole responsibility of the authors and OBETS. Revista de Ciencias Sociales does not necessarily agree with them. The authors hold the copyright of their articles without restrictions. 
